INSTITUTO DE PESQUISAS ENERGÉTICAS E NUCLEARES

Autarquia associada à Universidade de São Paulo

Desenvolvimento e avaliação da incorporação e liberação de óleo de açaí em hidrogéis de poli(N-vinil-2-pirrolidona)

Ana Carolina Henriques Ribeiro Machado

Dissertação apresentada como parte dos requisitos para obtenção do Grau de Mestre em Ciências na Área de Tecnologia Nuclear - Materiais

Orientador:

Dr. Ademar Benévolo Lugão

São Paulo

2010 


\section{AGRADECIMENTOS}

Ao meu orientador, Dr. Ademar Benévolo Lugão, pelos ensinamentos passados.

À MSc. Sizue Ota Rogero por estar ao nosso lado nos momentos mais difíceis.

Ao Dr. Oscar Vega por disponibilizar seu tempo, conhecimento e amizade.

À Dra. Angélica Cassemiro, da Beraca, pela doação do Óleo de Açaí.

À Dra. Patrícia Ponce, ao Dr. José Roberto Rogero e ao Dr. Antônio Brant pelas preciosas dicas nos exames de capacidade e seminário de área.

A todos que colaboraram na execução dos meus ensaios: Dra. Áurea Cruz, Dra. Ligia Miyamaru e Dra. Maria Cristina Santa Bárbara, do Instituto Adolfo Lutz. Dr. Jorge Sarkis, Jailson, Dra. Elaine, Dr. Helio Ferreto, Elizabeth Somessari e Carlos Silveira, do Ipen.

Aos funcionários da Pós Graduação que sempre se disponibilizaram a nos ajudar.

Aos amigos Patrícia Lopes e Norio Nakashima, que me incentivaram a dar este passo na vida.

Às minhas queridas amigas Roberta, Renata, Mara e a todos os que passaram pelo laboratório nesse período. Meninas, obrigada pela força, amizade, risadas e lágrimas juntas!

Às minhas amigas e professoras Ada, Tika, Edmara, Maria Tereza, Myrian e Elda por sempre terem uma palavra de incentivo nos momentos mais difíceis. 
Aos meus pais, Anabela e Francisco, por sempre me ensinarem que 0 estudo é o melhor caminho que temos a seguir e que com amor tudo fica mais fácil.

Aos meus irmãos, cunhadas e sobrinhos pelos abraços energizantes nos momentos em que não havia mais forças.

Ao meu marido, Marcelo, pelo seu amor, dedicação e incentivo, por compreender a minha ausência e por sempre acreditar em mim.

A Deus por guiar os meus caminhos sempre!

Muito obrigada a todos que de alguma forma me ajudaram. 
"De tudo, ficaram três coisas: A certeza de que estamos sempre recomeçando...

A certeza de que precisamos continuar... A certeza de que seremos interrompidos antes de terminar... Portanto, devemos fazer da interrupção um caminho novo... Da queda, um passo de dança... Do medo, uma escada...

Do sonho, uma ponte... Da procura, um encontro..." 


\title{
DESENVOLVIMENTO E AVALIAÇÃO DA INCORPORAÇÃO E LIBERAÇÃO DE ÓLEO DE AÇAÍ EM HIDROGÉIS DE POLI(N-VINIL-2-PIRROLIDONA)
}

\author{
Ana Carolina Henriques Ribeiro Machado
}

\section{RESUMO}

O açaí (Euterpe oleracea) é uma palmeira nativa do Brasil, distribuída por toda a bacia amazônica. Rico em ácidos graxos essenciais (principalmente o ácido oleico e o ácido linoleico), o óleo de açaí previne condições anormais da pele, como dermatites, escamações e ressecamento, e auxilia no processo de regeneração do tecido epitelial. Conhecendo-se os benefícios dos hidrogéis como curativos, esse trabalho objetivou desenvolver hidrogéis de poli( $N$-vinil-2pirrolidona) (PVP) como um sistema de liberação de óleo de açaí para uso tópico em desordens cutâneas. Desconhecendo-se o comportamento do óleo de açaí frente à radiação, foi avaliada a composição de ácidos graxos do óleo antes e após ser submetido à radiação. Duas diferentes matrizes de hidrogel de PVP foram avaliadas quanto às suas características físicas e químicas por meio de ensaios de intumescimento, fração gel, propriedades mecânicas e citotoxicidade in vitro. As duas matrizes foram consideradas adequadas para serem utilizadas como sistema de liberação. Os dispositivos foram obtidos pela incorporação do óleo de açaí nas matrizes de hidrogel de PVP e submetidos aos ensaios de intumescimento, fração gel, propriedades mecânicas e citotoxicidade in vitro, além dos ensaios de caracterização por microscopia eletrônica de varredura e irritação cutânea primária in vivo. Os dois dispositivos de hidrogel de PVP foram submetidos ao ensaio de cinética de liberação por 24 h e o óleo de açaí liberado foi quantificado por cromatografia a gás acoplada a espectrometria de massas, e se mostraram satisfatórios para compor um sistema de liberação de ativos. 


\title{
AÇAÍ OIL DEVELOPMENT AND EVALUATION OF IMMOBILIZATION AND RELEASE IN POLY (N-VINYL-PYRROLIDONE) HYDROGELS
}

\author{
Ana Carolina Henriques Ribeiro Machado
}

\begin{abstract}
Acaí (Euterpe oleracea) is a native palm of Brazil, distributed for the entire Amazonian basin. Rich in essentials fatty acids (mainly oleic acid and linoleic acid), acaí oil prevents abnormal conditions of the skin, as dermatitis and drying, and assists in the regeneration of the epidermis. The benefits of the hydrogels are known as dressings. The purpose of this study was to develop devices for controlled release of acaí oil on poly (N-vynil-2-pyrrolidone) (PVP) hydrogels. The behavior of the acai oil front to the radiation was evaluated by the composition of fatty acids of the oil before and after irradiation. Two different matrices of PVP hydrogel were evaluated physically and chemically through assays of swelling, gel fraction, mechanical proprieties and in vitro cytotoxicity. Both matrices were considered adjusted to be used as an active release system. The devices were obtained by acai oil immobilization in PVP hydrogel matrices, were also characterized through assays of sweeling, gel fraction, mechanical proprieties and in vitro cytotoxicity. Moreover, they were characterized by assays of scanning electron microscopy and in vivo primary cutaneous irritation. Both devices were submitted to assay of active release kinetics, and the acai oil was quantified by gas chromatography coupled with mass spectrometry. The devices showed to be satisfactory to compose a release system of actives.
\end{abstract}




\section{SUMÁRIO}

1 INTRODUÇÃO

2 OBJETIVOS

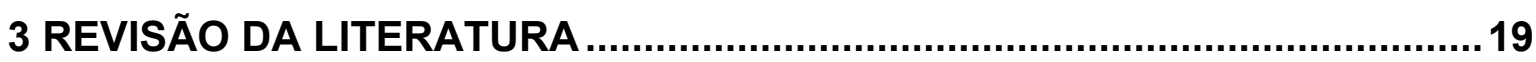

3.1 Pele

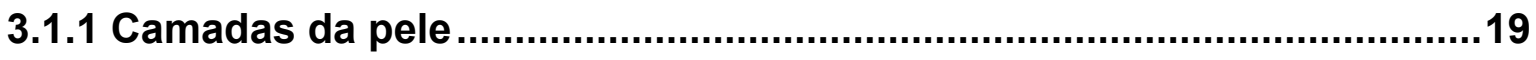

3.1.2 Composição hidrolipídica da epiderme ................................................22

3.1.3 Composição lipídica do estrato corneo .................................................23

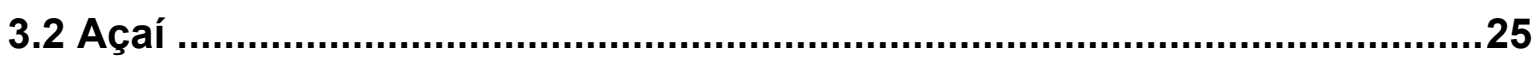

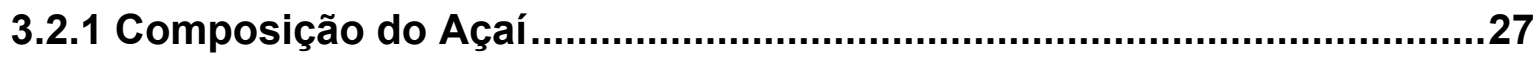

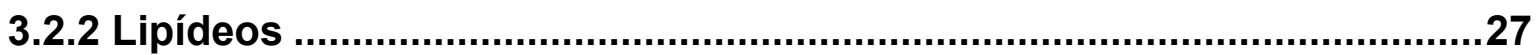

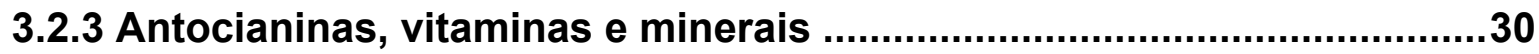

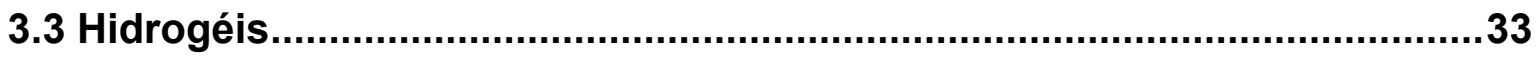

3.3.1 Interação da radiação ionizante com a matéria e a sua ação em

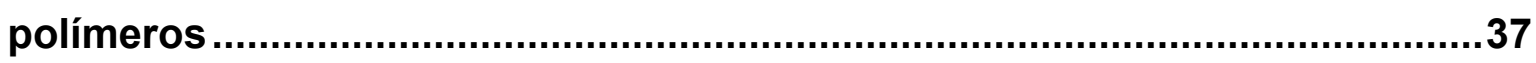

3.3.2 Hidrogéis de poli( $N$-vinil-2-pirrolidona) ….........................................39

3.4 Sistemas de liberação de ativos na pele ....................................................

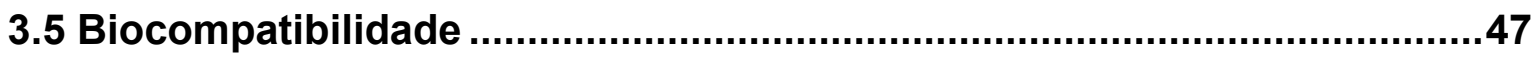

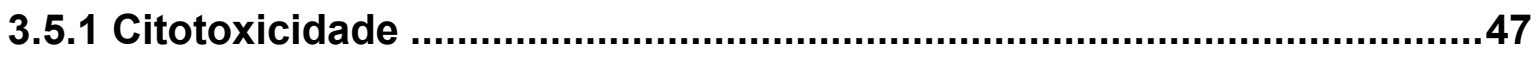

3.5.2 Irritação cutânea primária ..........................................................................48

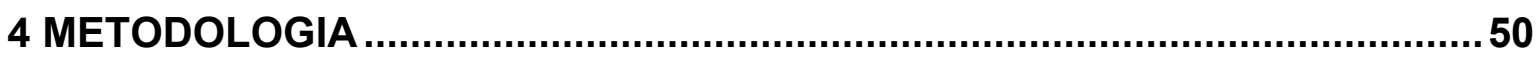

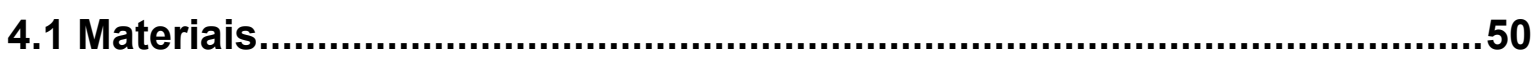

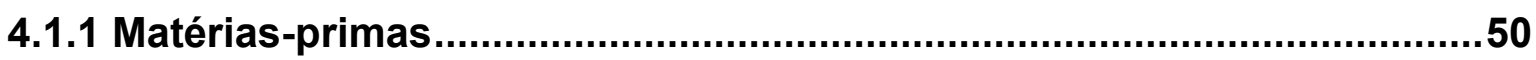

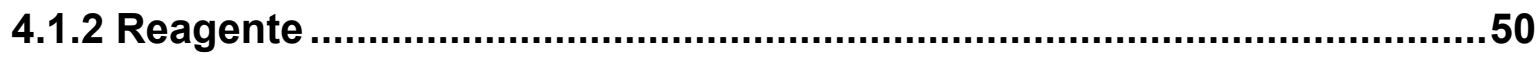

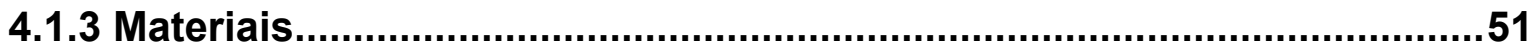

4.1.4 Equipamentos .....................................................................................51

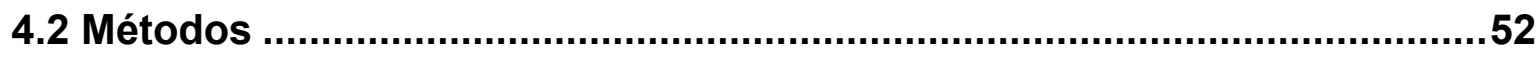

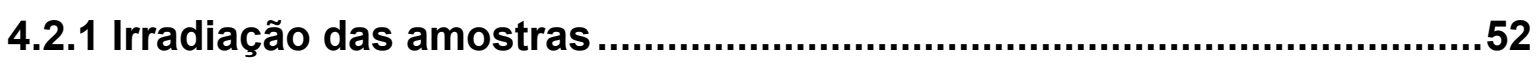

4.2.2 Determinação dos efeitos da radiação no óleo de açaí ...........................54

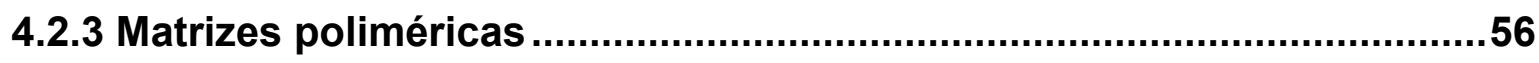

4.2.3.1 Obtenção das matrizes poliméricas ...................................................56

4.2.3.2 Fração gel ........................................................................................... 


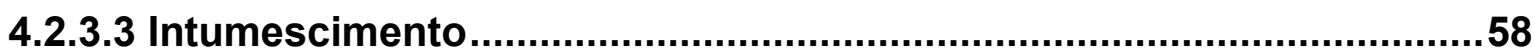

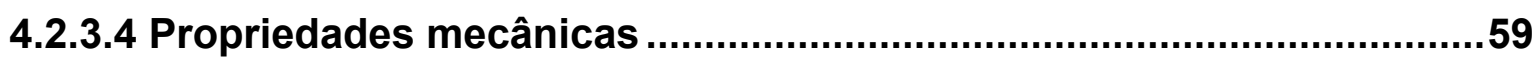

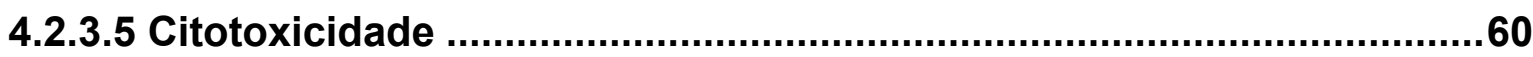

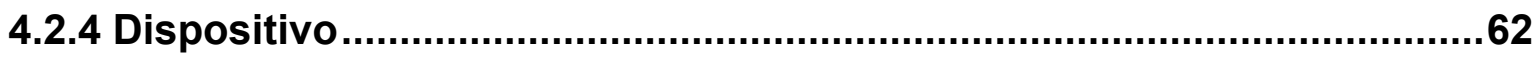

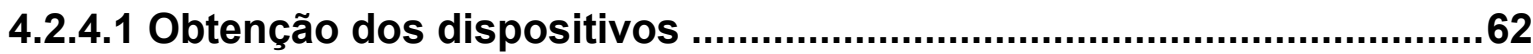

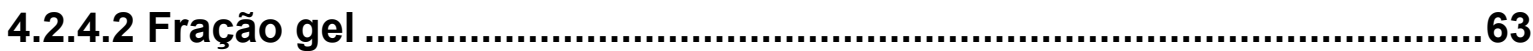

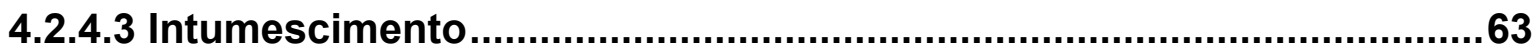

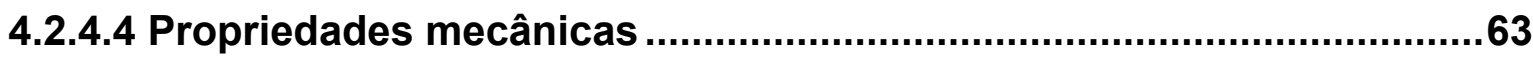

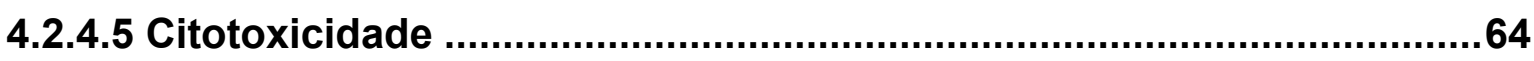

4.2.4.6 Irritação Cutânea Primária...................................................................64

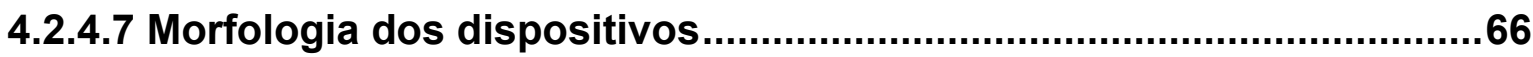

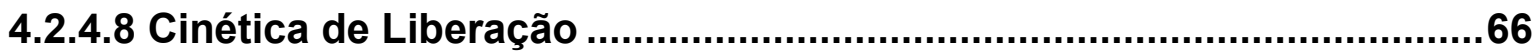

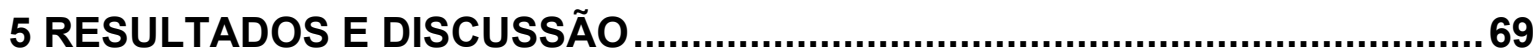

5.1 Determinação do efeito da radiação no óleo de açaí ...................................69

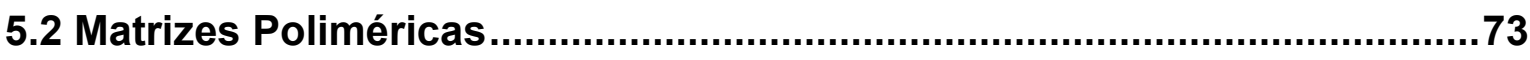

5.2.1 Obtenção das matrizes poliméricas ...................................................73

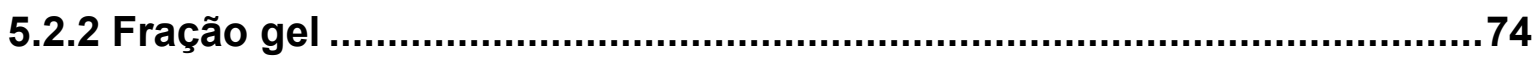

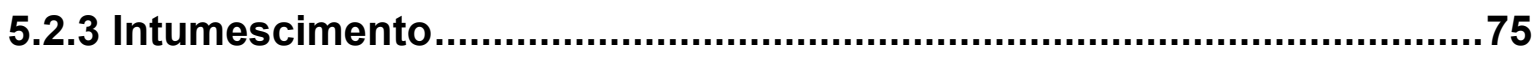

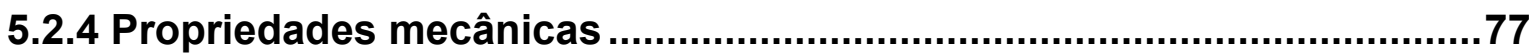

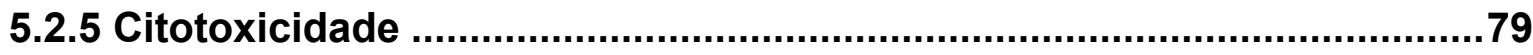

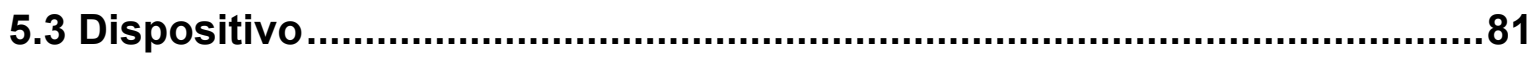

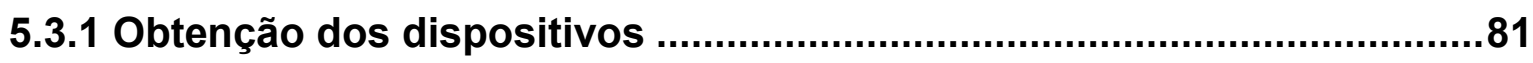

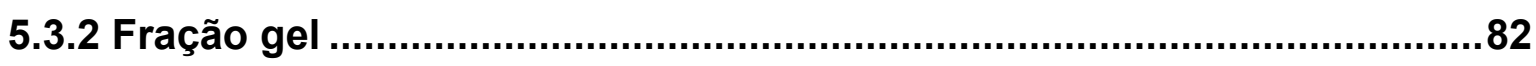

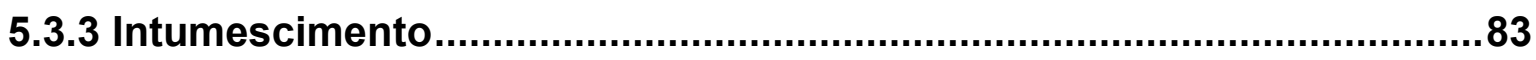

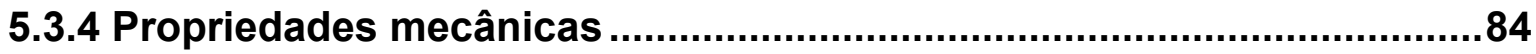

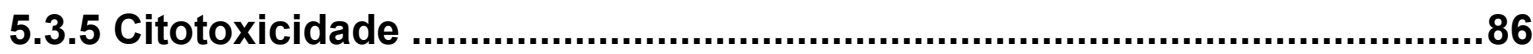

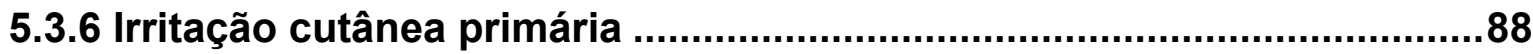

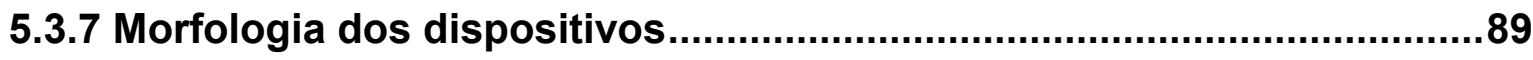

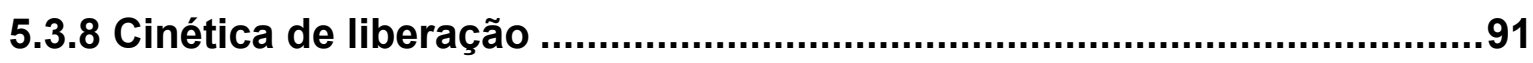

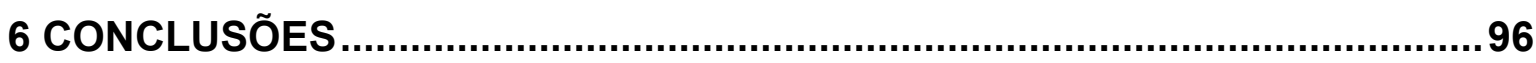

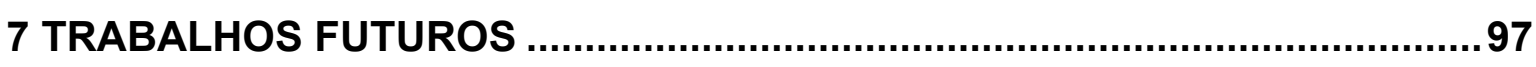

APÊNDICE A - Cromatogramas do padrão de ácido oleico............................98 APÊNDICE B - Cromatogramas da liberação de ácido oleico pelo dispositivo

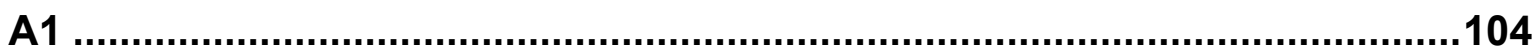


APÊNDICE C - Cromatogramas da liberação de ácido oleico pelo dispositivo

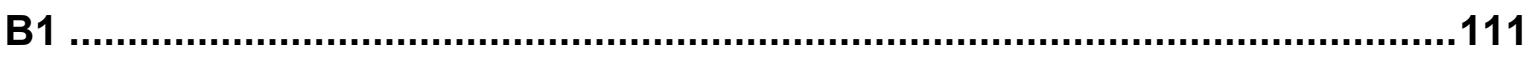

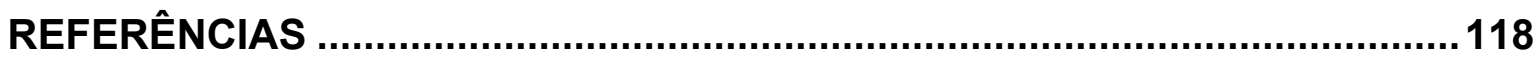




\section{LISTA DE TABELAS}

TABELA 1 - Composição lipídica média durante a diferenciação epidermal humana e cornificação 23

TABELA 2 - Teores de nutrientes de açaí e valor correspondente à

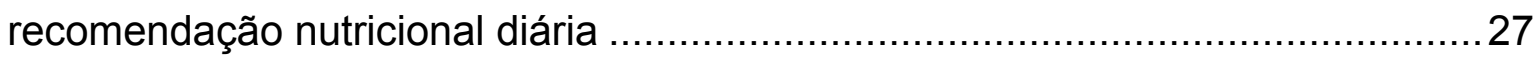

TABELA 3 - Composição de ácidos graxos, esteróis, tocoferóis e tocotrienóis de

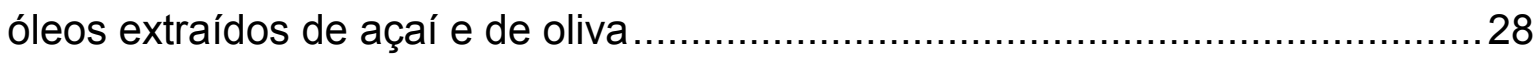

TABELA 4 - Principais polímeros usados em sistemas de liberação de ativos .....43

TABELA 5 - Classificação dos sistemas de liberação controlada. .........................44

TABELA 6 - Composição das matrizes de hidrogel de PVP .................................57

TABELA 7 - Composição dos dispositivos de hidrogel de PVP ...........................62

TABELA 8 - Graduação do eritema formado como reação cutânea ......................65

TABELA 9 - Graduação do edema formado como reação cutânea ........................66

TABELA 10 - Análise semiquantitativa dos ácidos graxos do óleo de açaí via CG/EM da amostra sem irradiar.

TABELA 11 - Análise semiquantitativa dos ácidos graxos do óleo de açaí via

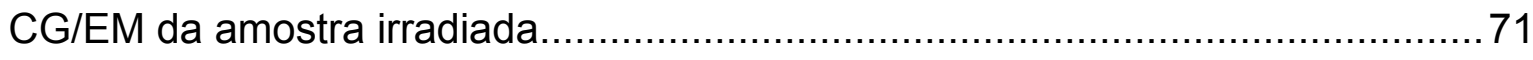

TABELA 12 - Análise quantitativa dos ácidos graxos do óleo de açaí ..................73

TABELA 13 - Resultados de fração gel das matrizes de hidrogel de PVP ...........75

TABELA 14 - Resultados de intumescimento das matrizes de hidrogel de PVP.. 76 TABELA 15 - Força máxima de perfuração e deformação das matrizes A obtidas

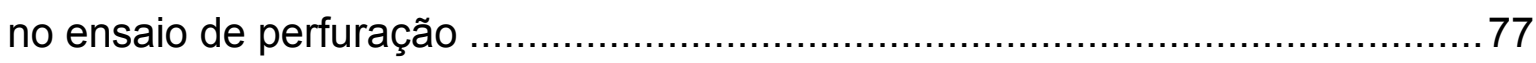

TABELA 16 - Força máxima de perfuração e deformação das matrizes B obtidas no ensaio de perfuração 78

TABELA 17 - Resultados de viabilidade celular das matrizes de hidrogel de PVP80 TABELA 18 - Resultados de fração gel dos dispositivos de hidrogel de PVP .......83

TABELA 19 - Resultados de intumescimento dos dispositivos de hidrogel PVP. 83 TABELA 20 - Força máxima de perfuração e deformação do dispositivo A1 obtida no ensaio de perfuração 85

TABELA 21 - Força máxima de perfuração e deformação do dispositivo B1 obtida no ensaio de perfuração 86

TABELA 22 - Resultados de viabilidade celular dos dispositivos de hidrogel de PVP. 
TABELA 23 - Leitura da graduação de edema e eritema dos dispositivos de

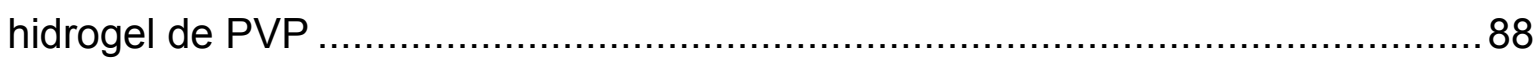

TABELA 24 - Quantidade de ácido oleico liberado no ensaio de cinética de

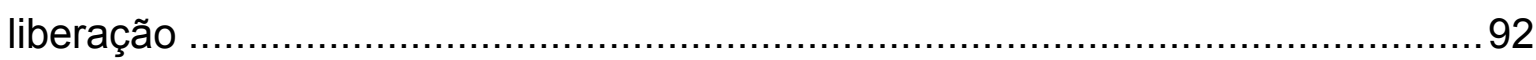

TABELA 25 - Quantidade de óleo de açaí presente nos dispositivos de hidrogel de PVP em relação à quantidade de ácido oleico ................................................. 93 


\section{LISTA DE FIGURAS}

FIGURA 1 - Camadas da pele e seus constituintes ………............................... 19

FIGURA 2 - Camadas da epiderme e suas principais estruturas ..........................20

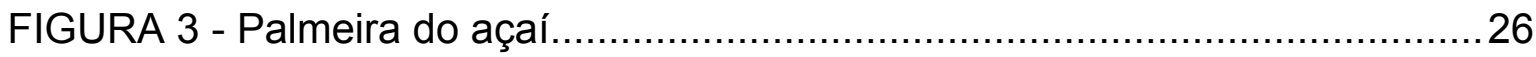

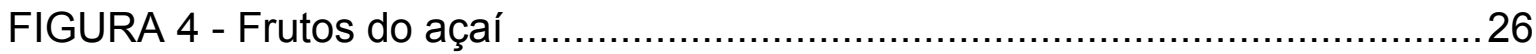

FIGURA 5 - Mecanismo simplificado da formação do radical polimérico, por meio

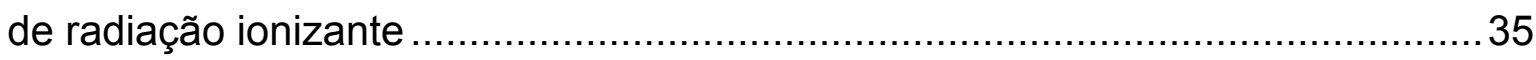

FIGURA 6 - Cisão da cadeia molecular dos polímeros expostos à radiação .........39

FIGURA 7 - Formação de ligações cruzadas, reticulação, de polímeros expostos à

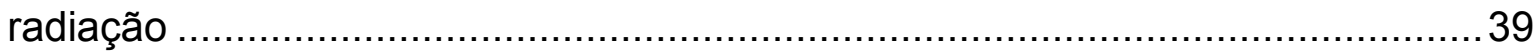

FIGURA 8 - Estrutura química do poli(N-vinil-2-pirrolidona) …............................40

FIGURA 9 - Representação da cadeia macromolecular reticulada........................ 45

FIGURA 10 - Sistema de liberação controlada por intumescimento .......................45

FIGURA 11 - Irradiador de ${ }^{60} \mathrm{Co}$ do tipo Gamacell 220 ....................................52

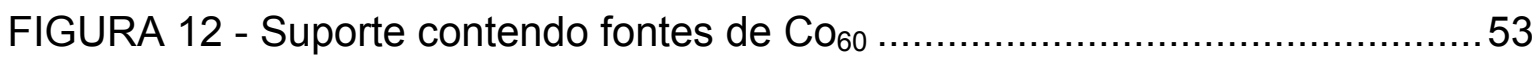

FIGURA 13 - Cromatógrafo a gás acoplado ao espectrômetro de massas, modelo

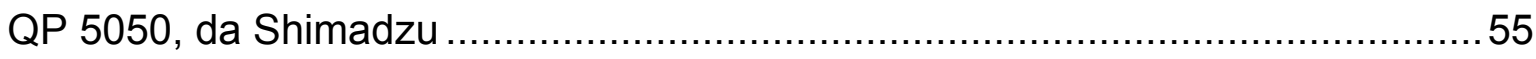

FIGURA 14 - Extrator Soxhlet com manta aquecedora .......................................58

FIGURA 15 - Texturômetro, modelo TA-TX2i da Stable Micro System..................60

FIGURA 16 - Esquema da distribuição dos extratos das amostras e dos controles

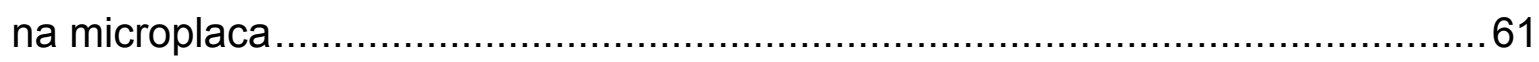

FIGURA 17 - Cromatograma do óleo de açaí não irradiado ................................. 1

FIGURA 18 - Cromatograma do óleo de açaí irradiado a 25 kGy .......................... 1 FIGURA 19 - Cromatograma do óleo de açaí para análise quantitativa dos ácidos

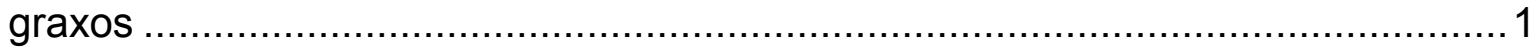

FIGURA 20 - Matriz de hidrogel de PVP - A: (a) transparência; (b) elasticidade .74 FIGURA 21 - Matriz de hidrogel de PVP - B: (a) transparência; (b) elasticidade .74 FIGURA 22 - Curvas de intumescimento das matrizes de hidrogel de PVP .........76 FIGURA 23 - Curva de força aplicada à matriz A para perfuração em função da distância percorrida pelo probe até a perfuração da mesma …………………....78 FIGURA 24 - Curva de força aplicada à matriz B para perfuração em função da distância percorrida pelo probe até a perfuração da mesma 
FIGURA 25 - Curvas de viabilidade celular das matrizes de hidrogel de PVP ......81 FIGURA 26 - Dispositivo de hidrogel de PVP - A1: (a) homogeneidade; (b)

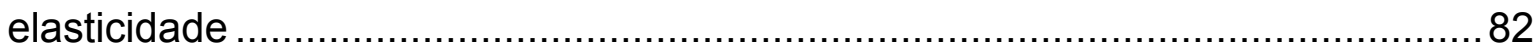

FIGURA 27 - Dispositivo de hidrogel de PVP - B1: (a) homogeneidade; (b) elasticidade

FIGURA 28 - Curvas de intumescimento dos dispositivos de hidrogel de PVP ....84 FIGURA 29 - Curva de força aplicada ao dispositivo A1 para perfuração em função da distância percorrida pelo probe até a perfuração do mesmo. FIGURA 30 - Curva de força aplicada ao dispositivo B1 para perfuração em função da distância percorrida pelo probe até a perfuração do mesmo. 86 FIGURA 31 - Curvas de viabilidade celular dos dispositivos de hidrogel de PVP no teste de citotoxicidade pelo método de incorporação do vermelho neutro. 87 FIGURA 32 - Região dorsal do coelho submetido ao ensaio de irritação cutânea primária: nenhuma reação cutânea é observada .88

FIGURA 33 - Micrografia panorâmica obtida em MEV do dispositivo A1 .............89 FIGURA 34 - Micrografia panorâmica obtida em MEV do dispositivo B1 .............89 FIGURA 35 - Micrografia obtida em MEV da superfície do dispositivo A1 ...........90 FIGURA 36 - Micrografia obtida em MEV da superfície do dispositivo B1. 90 FIGURA 37 - Gráfico da concentração de óleo de açaí liberado em relação ao tempo .94

FIGURA 38 - Cromatograma do padrão de ácido oleico $80 \mu \mathrm{g} / \mathrm{mL}$ - 1ª injeção ...98 FIGURA 39 - Cromatograma do padrão de ácido oleico $80 \mu \mathrm{g} / \mathrm{mL}-2^{a}$ injeção .....1 FIGURA 40 - Cromatograma do padrão de ácido oleico $80 \mu \mathrm{g} / \mathrm{mL}$ - 3a injeção ...99 FIGURA 41 - Cromatograma do padrão de ácido oleico $128 \mu \mathrm{g} / \mathrm{mL}$ - $1^{\text {a }}$ injeção 99 FIGURA 42 - Cromatograma do padrão de ácido oleico $128 \mu \mathrm{g} / \mathrm{mL}$ - 2a injeção100 FIGURA 43 - Cromatograma do padrão de ácido oleico $128 \mu \mathrm{g} / \mathrm{mL}$ - 3a injeção100 FIGURA 44 - Cromatograma do padrão de ácido oleico $160 \mu \mathrm{g} / \mathrm{mL}$ - $1^{\mathrm{a}}$ injeção101 FIGURA 45 - Cromatograma do padrão de ácido oleico $160 \mu \mathrm{g} / \mathrm{mL}$ - 2a injeção101 FIGURA 46 - Cromatograma do padrão de ácido oleico $160 \mu \mathrm{g} / \mathrm{mL}$ - $3^{\mathrm{a}}$ injeção102 FIGURA 47 - Cromatograma do padrão de ácido oleico $192 \mu \mathrm{g} / \mathrm{mL}$ - $1^{\mathrm{a}}$ injeção102 FIGURA 48 - Cromatograma do padrão de ácido oleico $192 \mu \mathrm{g} / \mathrm{mL}$ - 2a injeção103 FIGURA 49 - Cromatograma do padrão de ácido oleico $192 \mu \mathrm{g} / \mathrm{mL}$ - 3a injeção103 FIGURA 50 - Cromatograma da liberação de ácido oleico pelo dispositivo A1, no tempo $1 \mathrm{~h}-1^{\mathrm{a}}$ injeção. 104 
FIGURA 51 - Cromatograma da liberação de ácido oleico pelo dispositivo A1, no tempo $1 \mathrm{~h}-2^{\mathrm{a}}$ injeção. 104

FIGURA 52 - Cromatograma da liberação de ácido oleico pelo dispositivo A1, no tempo $2 \mathrm{~h}-1^{\mathrm{a}}$ injeção. 105

FIGURA 53 - Cromatograma da liberação de ácido oleico pelo dispositivo A1, no tempo $2 \mathrm{~h}-2^{\mathrm{a}}$ injeção. 105

FIGURA 54 - Cromatograma da liberação de ácido oleico pelo dispositivo A1, no tempo $3 \mathrm{~h}-1^{\mathrm{a}}$ injeção. 106

FIGURA 55 - Cromatograma da liberação de ácido oleico pelo dispositivo A1, no tempo $3 \mathrm{~h}-2^{\mathrm{a}}$ injeção. 106

FIGURA 56 - Cromatograma da liberação de ácido oleico pelo dispositivo A1, no tempo $4 \mathrm{~h}-1^{\mathrm{a}}$ injeção. 107

FIGURA 57 - Cromatograma da liberação de ácido oleico pelo dispositivo A1, no tempo $4 \mathrm{~h}-2^{\mathrm{a}}$ injeção. 107

FIGURA 58 - Cromatograma da liberação de ácido oleico pelo dispositivo A1, no tempo $5 \mathrm{~h}-1^{\mathrm{a}}$ injeção. 108

FIGURA 59 - Cromatograma da liberação de ácido oleico pelo dispositivo A1, no tempo $5 \mathrm{~h}-2^{\mathrm{a}}$ injeção. 108

FIGURA 60 - Cromatograma da liberação de ácido oleico pelo dispositivo A1, no tempo $6 \mathrm{~h}-1^{\mathrm{a}}$ injeção. 109

FIGURA 61 - Cromatograma da liberação de ácido oleico pelo dispositivo A1, no tempo $6 \mathrm{~h}-2^{\mathrm{a}}$ injeção. 109

FIGURA 62 - Cromatograma da liberação de ácido oleico pelo dispositivo A1, no tempo $24 \mathrm{~h}-1^{\mathrm{a}}$ injeção. 110

FIGURA 63 - Cromatograma da liberação de ácido oleico pelo dispositivo A1, no tempo $24 \mathrm{~h}-2^{\mathrm{a}}$ injeção. 110

FIGURA 64 - Cromatograma da liberação de ácido oleico pelo dispositivo B1, no tempo $1 \mathrm{~h}-1^{\mathrm{a}}$ injeção.

FIGURA 65 - Cromatograma da liberação de ácido oleico pelo dispositivo B1, no tempo $1 \mathrm{~h}-2^{\mathrm{a}}$ injeção.

FIGURA 66 - Cromatograma da liberação de ácido oleico pelo dispositivo B1, no tempo $2 \mathrm{~h}-1^{\mathrm{a}}$ injeção.

FIGURA 67 - Cromatograma da liberação de ácido oleico pelo dispositivo B1, no tempo $2 \mathrm{~h}-2^{\mathrm{a}}$ injeção. 
FIGURA 68 - Cromatograma da liberação de ácido oleico pelo dispositivo B1, no tempo $3 \mathrm{~h}-1^{\mathrm{a}}$ injeção 113

FIGURA 69 - Cromatograma da liberação de ácido oleico pelo dispositivo B1, no tempo $3 \mathrm{~h}-2^{\mathrm{a}}$ injeção. 113 FIGURA 70 - Cromatograma da liberação de ácido oleico pelo dispositivo B1, no tempo $4 \mathrm{~h}-1^{\mathrm{a}}$ injeção. 114 FIGURA 71 - Cromatograma da liberação de ácido oleico pelo dispositivo B1, no tempo $4 \mathrm{~h}-2^{\mathrm{a}}$ injeção. 114 FIGURA 72 - Cromatograma da liberação de ácido oleico pelo dispositivo B1, no tempo $5 \mathrm{~h}-1^{\mathrm{a}}$ injeção. 115 FIGURA 73 - Cromatograma da liberação de ácido oleico pelo dispositivo B1, no tempo $5 \mathrm{~h}-2^{\mathrm{a}}$ injeção 115 FIGURA 74 - Cromatograma da liberação de ácido oleico pelo dispositivo B1, no tempo $6 \mathrm{~h}-1^{\mathrm{a}}$ injeção. 116 FIGURA 75 - Cromatograma da liberação de ácido oleico pelo dispositivo B1, no tempo $6 \mathrm{~h}-2^{\mathrm{a}}$ injeção 116

FIGURA 76 - Cromatograma da liberação de ácido oleico pelo dispositivo B1, no tempo $24 \mathrm{~h}-1^{\text {a }}$ injeção. 117

FIGURA 77 - Cromatograma da liberação de ácido oleico pelo dispositivo B1, no tempo $24 \mathrm{~h}-2^{\mathrm{a}}$ injeção 117 


\section{INTRODUÇÃO}

A pele é constituída por cerca de $70 \%$ de água, dos quais 10 a $20 \%$ encontram-se no estrato corneo (Barata, 2003; Hernandez et al., 1999). Na epiderme desidratada, cerca de 10 a $14 \%$ do seu peso corresponde aos lipídeos (Taube \& Taieb, 2000). Os lipídeos proporcionam ao estrato corneo a função de barreira cutânea, por se organizarem em lamelas e preencherem todo o espaço intracelular da camada córnea. Ceramidas, colesterol e ácidos graxos livres são os principais lipídeos encontrados no estrato corneo (Michniak-Kohn, 2005).

A organização das estruturas lamelares e intercelulares do estrato corneo se dá por interações físicas, sendo que a reconstituição dessas estruturas pela incorporação de lipídeos externos (aplicação tópica) é possível, além de viável, permitindo a recomposição da barreira cutânea (Harris, 2005).

O açaí é uma palmeira nativa do Brasil, cultivada nos estados do Pará, Amazonas, Maranhão e do Amapá. Utilizado como fonte de alimento devido a sua composição nutricional, é rico em fitoesteróis, antocianinas, ácidos graxos essenciais (principalmente ácido linoleico e ácido oleico), vitamina $\mathrm{C}$, vitamina $\mathrm{E}$, manganês, cobre, bromo e zinco. Sua principal composição é de matéria graxa, a qual varia de 45 a $53 \%$ da matéria seca do fruto. Assim, o óleo de açaí (Euterpe oleracea pulp oil), que possui os mesmos benefícios do fruto (Lubrano et al., 1994; Rogez, 2000), tem sido amplamente pesquisado para fins cosméticos devido ao seu poder de regeneração do tecido epitelial por meio da ação antioxidante, hidratante, reguladora de lipídeos e estimulante do processo de cicatrização.

Os ácidos graxos linoleico (Ômega 6) e oleico (Ômega 9), conhecidos como ácidos graxos essenciais, não são sintetizados pelo organismo humano, devendo ser fornecidos pela dieta. Sua deficiência causa condições anormais da pele (dermatite, ressecamento e escamações), redução na regeneração dos tecidos, aumento da susceptibilidade às infecções, aumento dos níveis de colesterol sanguíneo, entre outros (Turatti et al., 2002). O óleo de açaí é constituído aproximadamente $12 \%$ de ácido linoleico e $60 \%$ de ácido oleico (Lubrano et al., 1994; Rogez, 2000). 
Hidrogéis poliméricos são estruturas poliméricas capazes de absorver grande quantidade água e diferentes fluidos biológicos que contenham grande quantidade de água (Peppas, 1996). Quando reticulados por meio de radiação ionizante, como a radiação gama, possuem vantagens como ausência de catalisadores e/ou iniciadores químicos que gerem toxicidade ao sistema; possibilidade de reações à temperatura ambiente ou mesmo a baixas temperaturas, se o sistema for refrigerado; possibilidade de controle de processo do início ao fim da irradiação; se a irradiação for realizada em sistema fechado, podem-se iniciar as reações e esterilizar o sistema de forma simultânea.

Os hidrogéis são utilizados como biomateriais de uso tópico por apresentarem as vantagens de absorver esxudação, promover barreira contra micro-organismos, permitir a permeabilidade do oxigênio e controlar a liberação de ativos, entre outros. Para tanto, devem ser inertes, apresentar resistência à degradação e não devem causar danos ao organismo (Peppas, 1996). Suas propriedades os tornam atrativos para uma variedade de aplicações farmacêuticas e biomédicas. Os primeiros curativos de hidrogel à base de PVP ((N-vinil-2-pirrolidona)) e PEG (polietilenoglicol) foram desenvolvidos por Rosiak e colaboradores em 1989 para o tratamento de queimaduras.

$\mathrm{Na}$ tentativa de maximizar as vantagens inerentes às formas farmacêuticas de liberação modificada, ampla variedade de sistemas tem sido objeto de investigação. A utilização de matrizes poliméricas é uma das estratégias mais empregadas no desenvolvimento de formulações de liberação modificada devido a vantagens como versatilidade, eficácia, baixo custo, além de permitir a incorporação de quantidades relativamente elevadas de substâncias ativas (Lopes et al., 2005).

Diversos ativos têm sido estudados usando a pele como via de administração. Sistemas de liberação de substâncias ativas na epiderme que maximizam o tempo de permanência na pele e minimizam a absorção transdérmica apresentam um importante papel no sucesso da terapia tópica local (Alencastre, et al., 2006).

A associação da tecnologia de liberação de substâncias ativas com os benefícios do óleo de açaí tornaram relevante o desenvolvimento de dispositivos de hidrogel de PVP contendo óleo de açaí e a avaliação das suas características, comparando estas com as das matrizes de hidrogel de PVP. 


\section{OBJETIVOS}

Desenvolvimento de hidrogéis de poli ( $N$-vinil-2-pirrolidona) contendo óleo de açaí e avaliação da sua liberação por meio da realização das metas seguintes:

- Avaliar o comportamento do óleo de açaí quando irradiado a uma dose suficiente para esterilizar hidrogéis;

- Avaliar as características físicas e químicas de duas diferentes matrizes de hidrogel de PVP, por meio de ensaios de intumescimento, fração gel, propriedades mecânicas e citotoxicidade in vitro;

- Avaliar as características físicas e químicas de dois diferentes dispositivos de hidrogel de PVP contendo óleo de açaí, por meio de ensaios de intumescimento, fração gel, propriedades mecânicas, morfologia por microscopia eletrônica de varredura, citotoxicidade in vitro e irritação cutânea primária in vivo;

- Analisar a cinética de liberação in vitro do óleo de açaí por meio das matrizes poliméricas. 


\section{REVISÃO DA LITERATURA}

\subsection{Pele}

\subsubsection{Camadas da pele}

A pele é o órgão mais pesado e extenso do corpo humano. Com uma arquitetura complexa exerce várias funções no organismo como proteção dos órgãos internos contra as variações de temperatura, umidade, radiação e poluição; limita a passagem de substâncias; regula a temperatura e a pressão sanguínea; mede as sensações do tato, calor e frio; sintetiza e metaboliza substâncias, entre outros. Anatomicamente, divide-se em hipoderme, derme e epiderme (FIG. 1) (Harris, 2005; Peyrefitte et al., 1998).

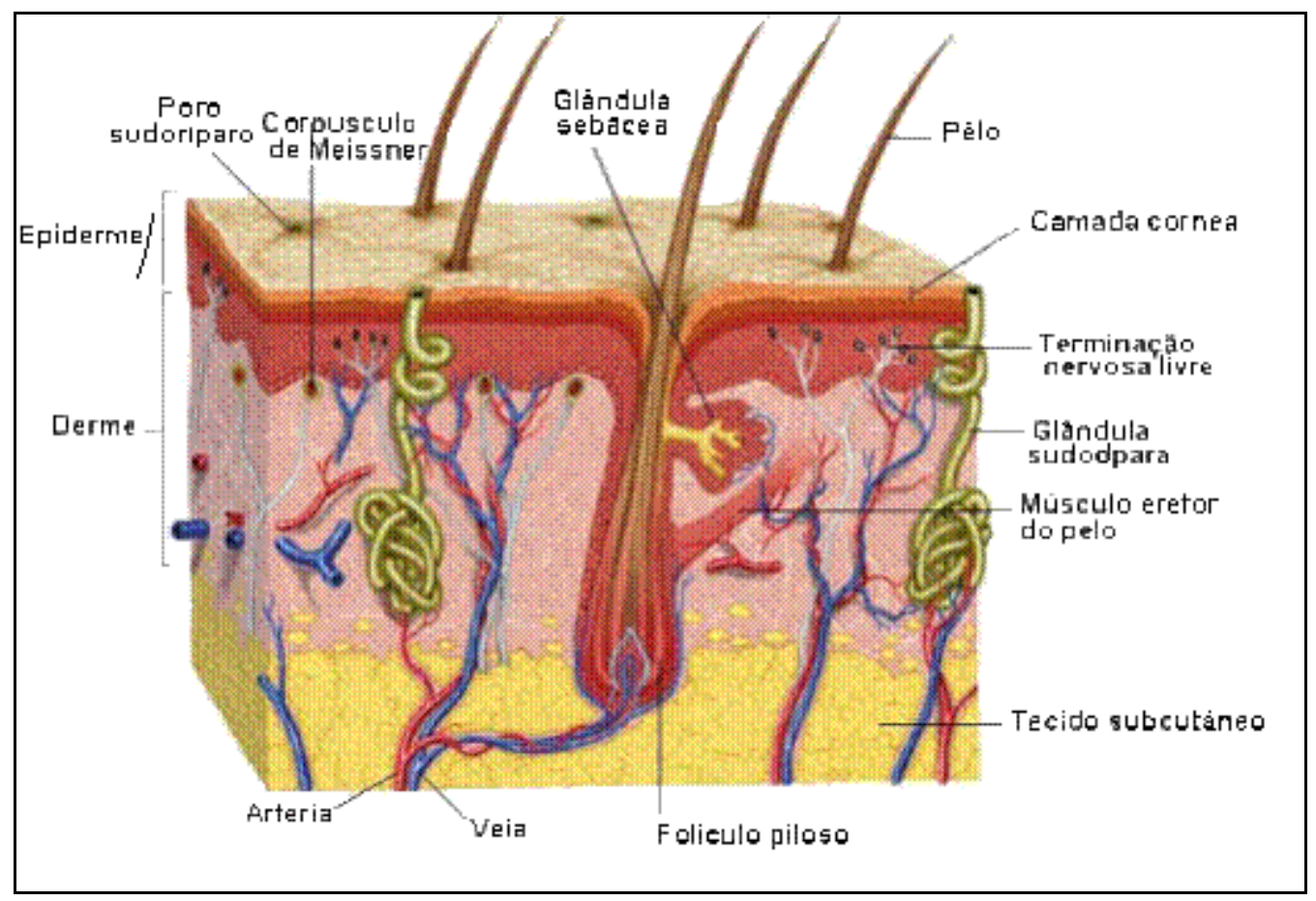

FIGURA 1 - Camadas da pele e seus constituintes

Fonte - A pele e o sentido do tato. Meio eletrônico.

Hipoderme ou tecido subcutâneo é a camada mais profunda onde está armazenada a gordura corpórea. É responsável pela termorregulação 
corporal e protege os demais órgãos internos contra traumas físicos (Barata, 2003; Peyrefitte et al.,1998).

Derme é a camada intermediária onde são encontrados os vasos sanguíneos, nervos, miofibroblastos, macrófagos e fibroblastos que são as principais células encontradas nessa camada, pois produzem fibras de colágeno, fibras elásticas, proteínas e enzimas. É um tecido de sustentação, compressível, extensível e elástico, que protege as redes vasculares e as fibras nervosas (Baumann, 2004).

Epiderme é a camada mais superficial, compactada e impermeável e não possui um sistema de irrigação sanguínea direta. A sua principal função é proteção contra o ambiente externo. É dividida em quatro subcamadas (estrato basal, estrato espinhoso, estrato granuloso e estrato corneo) (FIG. 2) e possui células epiteliais como queratinócitos, melanócitos, células de Langerhans e células de Merkel (Harris, 2005).

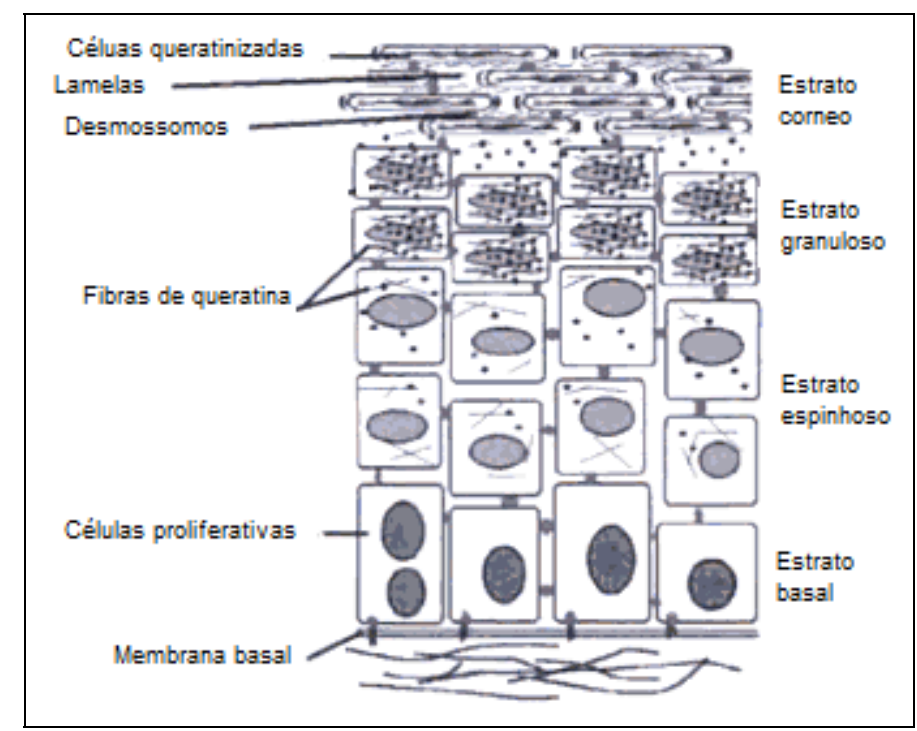

FIGURA 2 - Camadas da epiderme e suas principais estruturas Fonte - Harris, 2005.

$\mathrm{Na}$ epiderme são encontrados alguns anexos como os foliculos pilosos, as glândulas sebaceas e as glândulas sudoriparas. As glândulas sebaceas estão sempre associadas a um foliculo piloso e produzem o sebo, uma substância oleosa que é a principal responsável pela lubrificação da superfície da pele (Oliveira et al., 2008). 
O estrato basal é a camada mais interna, localizado na base da epiderme. As células basais unem-se com outras células espinhosas sobrejacentes por meio dos desmossomos, formando assim esta camada. É constituída por células matrizes e células proliferativas. A cada mitose aproximadamente $50 \%$ dessas células contribuem para renovação da epiderme. (Baumann, 2004).

Nessa camada se localizam os melanócitos, as células de Langerhans e as células de Merkel, responsáveis pela produção de melanina, reações de sensibilização e alergias cutâneas por contato, e pelo tato, respectivamente (Harris, 2005).

É no estrato espinhoso que aparecem os grânulos lamelares e iniciase a formação dos corneócitos, formando um citoesqueleto rígido que proporciona maior resistência mecânica às células. Esses grânulos contêm lipídeos como ceramidas, colesterol e ácidos graxos, e também enzimas como a fosfatase ácida, lipases e glicosidases, que posteriormente serão responsáveis pela formação do manto hidrolipídico (Baumann, 2004).

Suas células espinhosas e poligonais apresentam poros entre si, que permitem a passagem de nutrientes necessários, que são difundidos por capilares da derme (Harris, 2005; Oliveira et al., 2008).

O estrato granuloso caracteriza-se pela rica presença de grânulos de queratina nas células. Após a maturação das células espinhosas, há perda do núcleo e achatamento dos queratinócitos, com formação de placas de queratina. É nesta camada que ocorre a síntese de proteínas responsáveis pela estruturação adequada do estrato corneo (Harris, 2005).

$\mathrm{Na}$ camada mais externa da epiderme localiza-se o estrato corneo, constituído por uma membrana única, perfurada apenas pelos orifícios das glândulas e dos pelos. Pode ser caracterizado como um mosaico de várias camadas, composto por intercalações de células hidrofílicas, denominadas corneocitos e por estruturas lipídicas lamelares intercelulares (Harris, 2005). É considerado como uma "camada morta" de células por não demonstrar síntese proteica e não responder a sinalização celular (Baumann, 2004).

O estrato corneo possui como função protetora evitar a perda de água transepidérmica, regulando o equilíbrio hídrico da pele. O fator de hidratação natural (Natural Moisturizing Factor - NMF), localizado intracelularmente e 
formado pela decomposição de aminoácidos e seus metabólitos, junto com os lipídeos liberados pelos grânulos lamelares, localizados extracelularmente, permitem ao estrato corneo desempenhar esse papel, fundamental na hidratação, elasticidade e flexibilidade da pele (Baumann, 2004; Harris, 2005).

Para a boa formação e funcionamento do estrato corneo, são necessários quatro constituintes: dupla camada lipídica, fator de hidratação natural, processo de descamação e os corneócitos. Quando estão funcionando normalmente, o estrato corneo não é apenas uma barreira contra a umidade relativa, mas também uma barreira efetiva contra microrganismos e substâncias químicas, além de impedir que a pele absorva agentes (Baumann, 2004; Draelos, 2005).

\subsubsection{Composição hidrolipídica da epiderme}

A pele é constituída por cerca de $70 \%$ de água, dos quais 10 a $20 \%$ encontram-se no estrato corneo (Barata, 2003; Hernandez et al., 1999; Marks, 2004). Os corneócitos retêm a água permeada na pele através de fibras de queratina que são altamente hidrofílicas e em uma pele saudável eles possuem altas concentrações de fator de hidratação natural que permitem fixar a água e mantê-la sem que haja seu desperdício (Harris, 2005; Hernandez et al., 1999).

No NMF são encontrados aminoácidos, glicídios, ácido pirrolidona carboxílico, ácido lático, ácido úrico e ureia. Estas substâncias são higroscópicas e possuem um baixo peso molecular, capazes de manter a água no estrato corneo (Hernandez et al., 1999). Em seu funcionamento normal, esse estrato é capaz de absorver grandes quantidades de água, mesmo quando os níveis de umidade externa são baixos (Baumann, 2004).

$\mathrm{Na}$ epiderme desidratada, cerca de 10 a $14 \%$ do seu peso corresponde aos lipídeos, os quais mudam drasticamente de composição e quantidade durante o processo de queratinização (Taube \& Taieb, 2000). Dentre a composição dos lipídeos existentes na superfície da pele estão incluídos triglicerídeos, ácidos graxos, esqualeno, ésteres de ceras, diglicerídeos, ésteres de colesterol e colesterol. Os lipídeos são produzidos no interior e expelidos dos 
grânulos lamelares ou são produzidos nas glândulas sebaceas e excretados para a superfície da pele através do foliculo piloso (Baumann, 2004).

TABELA 1 - Composição lipídica média durante a diferenciação epidermal humana e cornificação

\begin{tabular}{|c|c|c|c|c|}
\hline Componente & $\begin{array}{c}\text { Estratos } \\
\text { basal e } \\
\text { espinhoso } \\
(\%)\end{array}$ & $\begin{array}{c}\text { Estrato } \\
\text { granuloso } \\
(\%)\end{array}$ & $\begin{array}{c}\text { Estrato } \\
\text { corneo total } \\
(\%)\end{array}$ & $\begin{array}{c}\text { Estrato } \\
\text { corneo } \\
\text { externo (\%) }\end{array}$ \\
\hline Lipídeos polares & 44,5 & 25,3 & 4,9 & 2,3 \\
\hline $\begin{array}{l}\text { Sulfato de } \\
\text { colesterol }\end{array}$ & 2,4 & 5,5 & 1,5 & 3,4 \\
\hline Lipídeos neutros & 51,0 & 56,5 & 77,7 & 68,4 \\
\hline Esteróis livres & 11,2 & 11,5 & 14,0 & 18,8 \\
\hline Ácidos graxos livres & 7,0 & 9,2 & 19,3 & 15,6 \\
\hline Triglicerídios & 12,4 & 24,7 & 25,2 & 11,2 \\
\hline $\begin{array}{l}\text { Ésteres de } \\
\text { colesterol / graxos }\end{array}$ & 5,3 & 4,7 & 5,4 & 12,4 \\
\hline Esqualeno & 4,9 & 4,6 & 4,8 & 5,6 \\
\hline$N-$ alcanos & 3,9 & 3,8 & 6,1 & 5,4 \\
\hline Esfingolipídeos & 7,3 & 11,7 & 18,1 & 26,6 \\
\hline Glucosilceramidas I & 2,0 & 4,0 & Traços & Traços \\
\hline Glucosilceramidas II & 1,5 & 1,8 & Traços & Traços \\
\hline Ceramidas I & 1,7 & 5,1 & 13,8 & 19,4 \\
\hline Ceramidas II & 2,1 & 3,7 & 4,3 & 7,2 \\
\hline
\end{tabular}

Fonte - Harris, 2005.

\subsubsection{Composição lipídica do estrato corneo}

Os corneócitos são envoltos por um envelope protéico unido às estruturas lamelares intercelulares por ligações ésteres. Esse envelope é 
constituído de duas partes: uma camada espessa composta por proteínas estruturais e uma camada fina externa formada por lipídeos (Harris, 2005).

No espaço intercelular dos corneócitos é observada uma estrutura de bicamada lipídica, composta essencialmente de esteróis, esfingolipídeos, ácidos graxos livres e lipídeos neutros (não polares), dispostas lado a lado. Os pares de bicamadas são unidos por moléculas de ceramidas 1, o que torna essa estrutura resistente à dispersão pelo calor ou pela ação de detergentes (Harris, 2005).

As ceramidas apresentam como estrutura básica um ácido graxo ligado covalentemente a uma base esfingoide. Seis tipos de ceramidas são conhecidos e denominados de acordo com a sua polaridade, sendo a ceramida 1 a mais apolar e a 6 a mais polar. A ceramida 1 é única por ser apolar e possuir ácido linoleico, o que Ihe fornece a função de "rebite molecular" por manter empilhadas as camadas lipídicas (Baumann, 2004).

Nas estruturas intercelulares os lipídeos encontram-se em duas fases: uma fase líquida e uma fase cristalina, constituída por moléculas longas atraídas por interações de Van der Waals, o que Ihe confere um caráter cristalino bem empacotado e impermeabilidade a água (Harris, 2005).

O colesterol desempenha o papel de auxiliar no empacotamento dos lipídeos das membranas celulares e ação detergente nas bicamadas do estrato corneo, aumentando a sua permeabilidade. Nas camadas mais externas do estrato corneo também são encontrados esqualeno e ácidos graxos oriundos do sebo produzidos nas glândulas sebaceas. Os ácidos graxos são também um dos responsáveis pela manutenção do $\mathrm{pH}$ ácido da pele, que garante a estabilidade da estrutura lamelar intercelular e viabiliza a ação de várias enzimas operantes no estrato corneo. Os lipídeos intercelulares possuem um papel tão importante quanto o da água na barreira cutânea (Marks, 2004; Harris, 2005).

O processo de maturação do estrato corneo ocorre após a completa queratinização das células da epiderme, última etapa de diferenciação celular, o qual deve estar completo para que haja a liberação dos corneócitos superficiais. Durante a maturação dos corneócitos, os lipídeos intercelulares são enzimaticamente modificados para diminuir a sua polaridade e produzir o NMF por meio da degradação da filagrina. Em seguida, as forças coesivas que mantêm os corneócitos aderidos são neutralizadas e ocorre a descamação (Harris, 2005). 
Em um processo equilibrado, a formação e a liberação de corneócitos ocorrem de maneira equilibrada e a renovação do estrato corneo não é percebida a olho nu. Desequilíbrios nesse processo levam a um estado de acúmulo de células parcialmente desconectadas, em que a liberação ocorre em placas e é observável a olho nu, comumente referida como "pele seca" ou "pele xerótica" (Harris, 2005).

Essa consequência nem sempre é resultado da perda de água da epiderme. Um desequilíbrio comumente encontrado no estrato corneo é a perda da organização dos lipídeos do manto hidrolipídico, os quais não se apresentam no estado líquido-cristalino à temperatura da superfície da pele, exibindo um polimorfismo complexo no qual as cadeias lipídicas estão firmemente empacotadas e imóveis (Harris, 2005).

A barreira cutânea é continuamente renovada de maneira controlada e organizada. Em condições normais, caso seja corrompida, uma série de processos bioquímicos são disparados de maneira que entre 24 e $36 \mathrm{~h}$ possa ser reparada. Conforme o trauma, esse tempo pode passar para 7 a 10 dias (Marks, 2004; Harris, 2005).

A organização das estruturas lamelares intercelulares dá-se unicamente por interações físicas. Assim, a reconstituição dessas estruturas pela incorporação de lipídeos substituintes é possível e viável, permitindo a recomposição da barreira lipídica (Harris, 2005), e acelerando o seu tempo de reconstituição (Marks, 2004).

\subsection{Açaí}

O açaizeiro, Euterpe oleracea C. Martius, é uma palmeira encontrada em toda a bacia amazônica, principalmente nos estados do Pará, Maranhão, Amapá, Acre e Rondônia (Menezes et al., 2008), sendo o estado do Pará responsável por 92\% da produção brasileira (Monteiro, 2006).

Apresenta estipes lisos e delgados que atingem uma altura de 10 à 35 metros, com diâmetro de 12 a $18 \mathrm{~cm}$. A cada ano, de 1 a 10 novos estipes aparecem na sua base, o que representa que sua regeneração é infinita. Seu ápice é constituído de um capitel de 9 a 15 folhas de cor verde-claro com um 
pecíolo de 20 a $40 \mathrm{~cm}$ e um comprimento total de 2 a 3,5 metros. Ao decorrer de todo ano, na axila das folhas, nascem inflorescências, que dão cachos com centenas de frutos (Rogez, 2000).

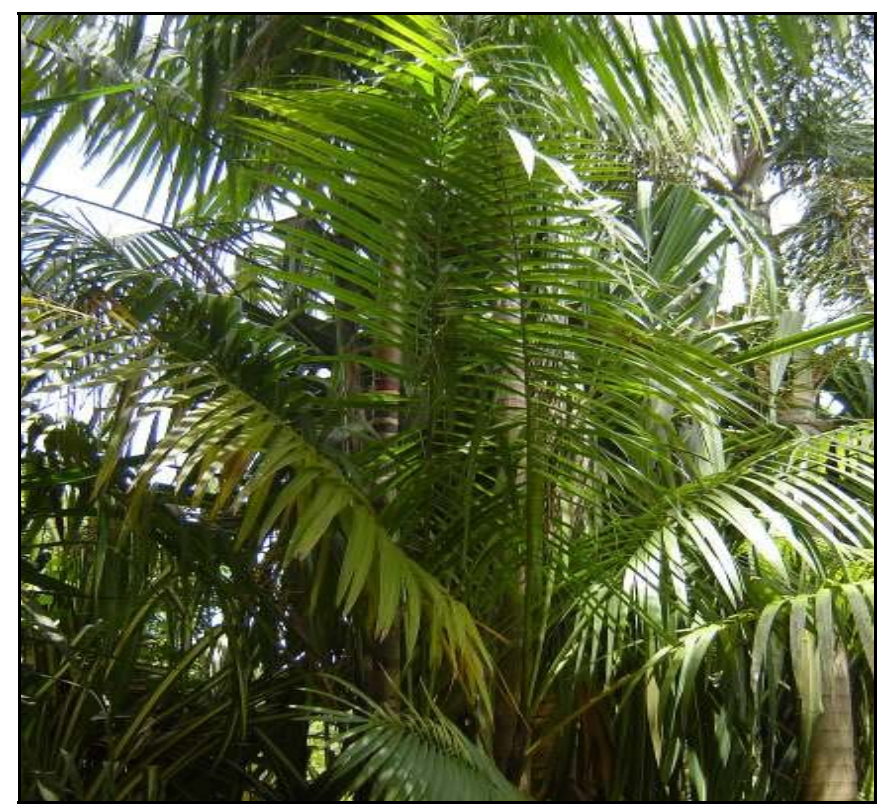

FIGURA 3 - Palmeira do açaí

Fonte - Galerie: Guadeloupe (Basse-Terre). Meio eletrônico.

Os frutos, chamados de açaí, são drupáceos, de forma globulosa, arredondada, com diâmetro de 1 a $2 \mathrm{~cm}$ e peso médio de 0,8 a 2,3 g (Rogez, 2000). Sua cor varia de violeta à púrpura escuro quando os frutos estão maduros, e verde antes de amadurecerem (Sanabria \& Sangronis, 2007).

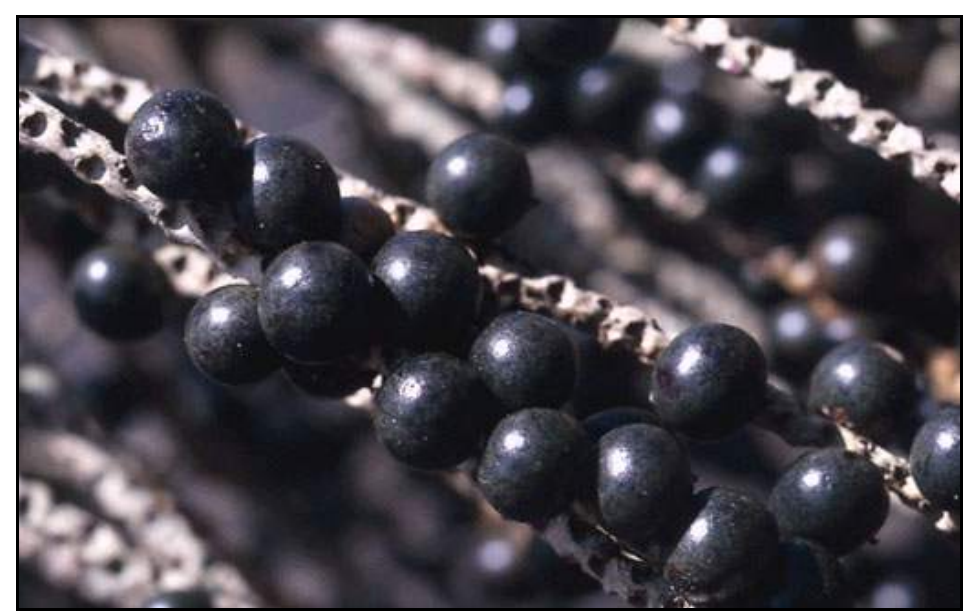

FIGURA 4 - Frutos do açaí

Fonte - Açaí (Euterpe oleracea Mart.). Meio eletrônico. 
Seu cultivo requer um clima tropical chuvoso (Sanabria \& Sangronis, 2007), assim, no Brasil ocorrem em todos os meses do ano, porém sua produção é intensificada entre os meses de setembro a dezembro (Nascimento et al., 2008).

\subsubsection{Composição do Açaí}

O açaí é um fruto rico em lipídeos, proteínas, fibras e antocianinas (TAB. 2), o que o faz ser amplamente consumido como alimento energético no Brasil nas formas de polpa congelada, suco e sorvete (Nascimento et al., 2008, Menezes et al., 2008).

TABELA 2 - Teores de nutrientes de açaí e valor correspondente à recomendação nutricional diária

\begin{tabular}{l|c|c}
\hline \multicolumn{1}{c|}{ Variável } & Teor $/ \mathrm{L}$ açaí & $\begin{array}{c}\text { Valor correspondente à } \\
\text { quantidade diária } \\
\text { recomendada (\%) }\end{array}$ \\
\hline Matéria graxa & $65,8 \mathrm{~g}$ & 66 \\
\hline Matéria nitrogenada total & $12,6 \mathrm{~g}$ & $25-31$ \\
\hline Glicose & $1,9 \mathrm{~g}$ & \multirow{2}{*}{$5-7$} \\
\hline Frutose & $1,7 \mathrm{~g}$ & \\
\hline Sacarose & $0,06 \mathrm{~g}$ & 90 \\
\hline Fibras & $31,5 \mathrm{~g}$ & - \\
\hline Antocianinas & $440 \mathrm{mg} / \mathrm{kg}$ & \\
\hline
\end{tabular}

Fonte - Rogez, 2000

\subsubsection{Lipídeos}

A principal composição do açaí é de matéria graxa, a qual varia de 45 a $53 \%$ da matéria seca do fruto, principalmente ácidos graxos monoinsaturados (60\%) e poli-insaturados (14\%) (TAB. 3) (Rogez, 2000). 
Um estudo realizado por Mantovani e colaboradores (2003) analisou a composição de ácidos graxos do pericarpo, endocarpo e dos frutos íntegros do açaí, e não encontrou diferenças significativas nas concentrações entre as diferentes partes do fruto, entretanto, na literatura são encontradas diferenças na composição do açaí, o que pode ser explicado por a matéria-prima ser de origem natural e sua composição variar conforme a época de colheita e o método de extração ou conservação (Nascimento et al., 2008).

TABELA 3 - Composição de ácidos graxos, esteróis, tocoferóis e tocotrienóis de óleos extraídos de açaí e de oliva

\begin{tabular}{|c|c|c|}
\hline Composição & Euterpe oleracea (açaí) $^{1}$ & Olea europea (oliva) ${ }^{2}$ \\
\hline \multicolumn{3}{|c|}{ Ácidos graxos (\% totais) } \\
\hline $\mathrm{C}_{16: 0}$ (palmítico) & 22 & $8-14$ \\
\hline $\mathrm{C}_{18: 0}$ (esteárico) & 2 & $3-6$ \\
\hline $\mathrm{C}_{20: 0}$ (araquídico) & 2,5 & $<0,9$ \\
\hline $\mathrm{C}_{18: 1}$ (oleico) & 60 & $61-80$ \\
\hline $\mathrm{C}_{18: 2}$ (linoleico) & 12 & $3-14$ \\
\hline $\mathrm{C}_{18: 3}$ (linolênico) & Traços & n.d \\
\hline \multicolumn{3}{|l|}{ Esteróis (\% totais) } \\
\hline Colesterol & 2,0 & $<0,3$ \\
\hline Campesterol & 6,0 & $2-4$ \\
\hline Stigmasterol & 6,5 & $<2$ \\
\hline$\beta$ Sitosterol & 78,0 & $75-93$ \\
\hline ¿5 Avenasterol & 6,5 & $3-11$ \\
\hline Outros & 1,0 & $<15$ \\
\hline
\end{tabular}

Tocoferóis (T) e Tocotrienóis (T3) (\% totais)

\begin{tabular}{|c|c|c|}
\hline aT 100\% & 67 & $52-87$ \\
\hline aT3 20\% & n.d & n.d \\
\hline$\beta$ T $30 \%{ }^{*}$ & 15 & $10-25$ \\
\hline VT 15\% & 1,3 & $7-23$ \\
\hline BT3 5\% & 17 & n.d \\
\hline
\end{tabular}

Fonte - ' Lubrano et al., 1994; ${ }^{2}$ Rogez, 2000.

Legenda: ${ }^{*}=$ poder antioxidante; n.d = não detectado. 
Ácidos graxos são compostos formados por uma cadeia de carbonos e um grupo carboxila final, que Ihes conferem propriedades lipossolúveis e ácidas, respectivamente. Os mais comuns apresentam cadeia de carbono que variam entre 12 e 22 átomos. Classificam-se como saturados quando cada átomo de carbono, exceto os dois terminais, é ligado a dois átomos de hidrogênio e, como insaturados quando cada um dos dois átomos adjacentes está ligado a somente um átomo de hidrogênio, ocorrendo uma ligação etilênica entre o par de carbonos e o ácido (Turatti et al., 2002).

Nos óleos, os ácidos graxos são na maioria de cadeia linear e diferemse entre si conforme o número de átomos de carbono, a presença de insaturação e o número e a posição de duplas ligações (Oetterer et al., 2006). As baixas temperaturas de fusão que caracterizam os óleos estão associadas com uma alta proporção de ácidos graxos insaturados (Coultate, 2004). Segundo recomendações nutricionais, um óleo deve conter pelo menos $50 \%$ de ácidos graxos monoinsaturados e no máximo 33\% de saturados (Rogez, 2000).

Os ácidos graxos poli-insaturados são os de maior importância nutricional por não serem metabolizados pelos seres humanos, devendo ser supridos pela alimentação (Oetterer et al., 2006; Turatti et al., 2002).

$O$ ácido linolênico é também conhecido como Ômega 3 e é encontrado em maior quantidade em produtos de origem marinha, já o ácido linoleico é conhecido como Ômega 6 e largamente encontrado em óleos vegetais. O ácido linoleico é precursor do ácido araquidônico, que por sua vez é precursor de eicosanóides, como as prostaglandinas, os tromboxanos e os leucotrienos, envolvidos nas funções dos sistemas cardiovascular, nervoso e imunológico, e também nas funções das glândulas endócrinas e exócrinas (Pacchioni, 1998; Turatti et al., 2002).

Um desequilíbrio dos ácidos graxos essenciais no organismo pode causar condições anormais da pele como dermatites, ressecamento e descamações, redução na regeneração de tecidos, aumento da susceptibilidade às infecções, aumento da permeabilidade cutânea e aumento a permeabilidade e fragilidade da membrana celular (Pacchioni, 1998; Turatti et al., 2002).

Os ácidos graxos essenciais são utilizados nos processos de regeneração cutânea por possuírem ação bactericida, aumentarem a 
permeabilidade da membrana celular, promoverem mitose e proliferação celular e auxiliarem no desbridamento (Mandelbaum et al., 2003).

Estudos em pacientes com dermatite atópica e em indivíduos normais encontraram diferenças nos níveis e na composição de ácidos graxos essenciais presentes na pele. Uma suplementação terapêutica com ácido linoleico, com dose diária de 2 a $6 \mathrm{~g} / \mathrm{dia}$ por um período de 8 a 12 semanas tem sido indicada para o tratamento da dermatite atópica (Castro et al., 1995).

O açaí possui uma elevada quantidade total de $\alpha$ - tocoferol (também conhecido como vitamina $E$ ), provavelmente relacionado à grande presença de ácidos graxos insaturados. A vitamina $\mathrm{E}$ é um potente antioxidante que ajuda a proteger os lipídeos (Rogez, 2000).

\subsubsection{Antocianinas, vitaminas e minerais}

Além de lipídeos, o açaí também possui uma grande quantidade de antocianinas, vitaminas e minerais, que podem ser observados no Quadro 1. 


\begin{tabular}{|c|c|}
\hline \multicolumn{2}{|l|}{ Minerais } \\
\hline Ca (g/kg M.S.) & 3,09 \\
\hline Mg (g/kg M.S.) & 1,78 \\
\hline K (g/kg M.S.) & 9,90 \\
\hline $\mathrm{Na}$ (g/kg M.S.) & 0,76 \\
\hline $\mathrm{Zn}$ (mg/kg M.S.) & 17,30 \\
\hline $\mathrm{Fe}$ (mg/kg M.S.) & 20,59 \\
\hline $\mathrm{Mn}(\mathrm{mg} / \mathrm{kg}$ M.S.) & 323 \\
\hline $\mathrm{Cu}(\mathrm{mg} / \mathrm{kg}$ M.S.) & 13,76 \\
\hline $\mathrm{Cr}(\mathrm{mg} / \mathrm{kg}$ M.S.) & 5,31 \\
\hline \multicolumn{2}{|l|}{ Vitaminas } \\
\hline Vitamina C (mg/100g M.S.) & 17 \\
\hline Vitamina B1 (mg/100g M.S.) & 0,67 \\
\hline Vitamina B2 (mg/100g M.S.) & 0,02 \\
\hline Vitamina B3 (mg/100g M.S.) & 0,7 \\
\hline \multicolumn{2}{|l|}{ Polifenóis } \\
\hline Antocianinas (mg/kg fruto) & 440 \\
\hline
\end{tabular}

\section{QUADRO 1 - Minerais e vitaminas do açaí}

Fonte - Rogez, 2000

Legenda: M.S. = matéria seca.

O açaí roxo é rico em antocianinas, pigmentos de estrutura polifenólica que oferecem ao açaí a sua cor e a ação antioxidante e antirradicalar (Rogez, 2000), anti-inflamatória e antimicrobiana, anticarcinogênica, preventiva de oxidação de proteínas de baixa densidade (LDL), enfermidades cardiovasculares e doenças neurológicas (Menezes et al., 2008). Bobbio e colaboradores (2000) realizaram um estudo para quantificar antocianinas presentes no açaí $e$ encontraram um teor de aproximadamente $500 \mathrm{mg} / 100 \mathrm{~g}$ do fruto, um valor considerável quando comparado aos de outras frutas de coloração vermelha / negra, como o morango (15 - $35 \mathrm{mg} / 100 \mathrm{~g}$ do fruto), a amora ( $345 \mathrm{mg} / 100 \mathrm{~g}$ do fruto) e a uva preta (356,95 mg/ $100 \mathrm{~g}$ do fruto) (Rogez, 2000). Estudos mostram que o açaí possui 10 vezes mais antioxidantes do que as uvas vermelhas (Beraca Sabará, 2007). 
No envelhecimento cronológico cutâneo, ocorrem modificações que diminuem o metabolismo e a proliferação celular, consequentemente o tecido cutâneo perde a elasticidade, a capacidade de regular as trocas aquosas e a multiplicação do tecido se torna menos eficiente. Oxidações químicas e enzimáticas envolvendo a formação de radicais livres aceleram esse processo (Hirata et al., 2004).

Radicais livres são moléculas que contem um elétron desemparelhado na sua órbita mais externa, o que implica em alta instabilidade energética. Para se manterem estáveis precisam doar ou retirar elétron de outra molécula. Esse estresse oxidativo origina uma cadeia de reações, que geram modificações celulares (Hirata et al., 2004).

Os compostos antioxidantes são capazes de reagir diretamente com os agentes oxidantes, por meio da doação de elétrons, impedindo a sua reação com os constituintes celulares. Componentes como os polifenóis, a vitamina $\mathrm{C}$ e a vitamina $E$ ajudam a eliminar os radicais livres, protegendo contra os danos do estresse oxidativo (Harris, 2009).

Vitaminas são compostos orgânicos essenciais às reações metabólicas específicas. A deficiência de qualquer vitamina pode provocar disfunção metabólica, sintomas patológicos ou até uma doença (De Carvalho, 2006).

A vitamina $\mathrm{C}$, ou ácido ascórbico, é considerada imprescindível ao organismo, por sua ação anti-inflamatória, cicatrizante, fortalecedora do sistema imunológico, estimuladora de colágeno, combatente de radicais livres, fotoprotetora e despigmentante da pele. Na pele é encontrada na epiderme em quantidade 5 vezes maior do que na derme (Macedo, 2001). A necessidade diária de vitamina C para um adulto é de $45 \mathrm{mg}$ (Dos Santos, et al., 2008), assim $100 \mathrm{~g}$ açaí suprem $37,8 \%$ da ingestão diária dessa vitamina.

Tiamina (vitamina B1) é necessária para o bom funcionamento das células nervosas e do cérebro. A riboflavina (vitamina B2) é essencial para o crescimento das células, produção das células vermelhas e para a saúde dos olhos e da pele. Deficiências suaves de tiamina resultam na falta de concentração, irritabilidade, depressão e fraqueza muscular. A deficiência de riboflavina pode ocorrer em combinação com a deficiência de outras vitaminas do complexo B. Sintomas de sua deficiência incluem boca inflamada com fissuras, pele seca e confusão mental (Maihara et al., 2006). 
A carência de niacina (vitamina B3) produz pelegra, doença de pele que leva á descamação e é precipitada pela exposição solar (Rigo, 2008).

Minerais são substâncias inorgânicas encontradas na natureza e que fornecem elementos essenciais ao organismo. Participam da estrutura celular, funcionam como eletrólitos, cofatores enzimáticos, entre outros (De Carvalho, 2006).

A presença de vários minerais, como o ferro e o zinco, são de fundamental importância ao bom funcionamento da pele. Além de possuir ação antioxidante, o ferro também é essencial para a oxidação de ácidos graxos, síntese de colágeno e à formação de neurotransmissores (De Carvalho, 2006).

O zinco é um mineral envolvido na estabilização de membranas estruturais e na proteção celular, prevenindo a peroxidação lipídica. Desempenha papel nas atividades do DNA e do RNA. Também está relacionado com as células do sistema imune, incluindo hipersensibilidade retardada, proliferação de linfócitos T. Sua deficiência pode causar alterações no hipotálamo, retardo no crescimento, cicatrização lenta, dermatite e alopecia (Mafra \& Cozzolino, 2004).

O cobre é um mineral fundamental para o bom funcionamento da pele, uma vez que atua como antioxidante, e está envolvido na síntese de colágeno e elastina e formação de melanina. A sua deficiência pode ocasionar despigmentação da pele e cabelos e alterações do sistema imunológico (De Carvalho, 2006).

A composição do óleo de açaí tem sido amplamente pesquisada para fins cosméticos devido ao seu poder de regeneração do tecido epitelial por meio da ação antioxidante, hidratante, reguladora de lipídeos e estimulante do processo de cicatrização.

\subsection{Hidrogéis}

Hidrogéis poliméricos são redes poliméricas capazes de absorver grande quantidade água e diferentes fluidos biológicos que contenham grande quantidade de água (Peppas, 1996). Característica esta que se dá pela presença de grupos hidrofílicos como: $=\mathrm{O},-\mathrm{OH},-\mathrm{COOH},-\mathrm{COONH} \mathrm{N}_{2}$ e $-\mathrm{SO}_{3} \mathrm{H}$, e o grau de reticulação. 
Os polímeros participantes dos hidrogéis são classificados conforme o seu método de preparação (homopolímeros ou copolímeros), sua carga iônica (neutro, aniônico, catiônico ou anfótero) ou características físicas estruturais do sistema (amorfa, semicristalina e tridimensional) (Peppas, 1996; Hamidi et al., 2008). Podem ser naturais, como o carboximetilcelulose (CMC), os poliamino ácidos, ou sintéticos, como o poli(N-vinil-2-pirrolidona) (PVP), o poli(óxido de etileno) e o poli(álcool vinílico) (PVA) (Fei et al., 2000).

Sua rede tridimensional é composta por homopolímeros ou copolímeros, que são insolúveis devido à presença de reticulação química ou física (Peppas et al., 2000). A reticulação química ocorre com a formação de ligações covalentes entre os polímeros; a reticulação física, por meio de interações eletrostáticas ou hidrofóbicas (Rosiak, 1994).

Quando secos, os hidrogéis poliméricos tornam-se quebradiços e quando inchados em água, tornam-se um gel elástico, preservando a sua forma natural. Ao intumescerem, os hidrogéis podem chegar ao estado de equilíbrio e compreenderem de aproximadamente 60 a $90 \%$ de fluido e apenas de 10 a $30 \%$ de polímero (Bevaresco et al., 2002). Os hidrogéis de uso médico que apresentam maior índice de intumescimento são os derivados de celulose, o PVA, o PVP e o polietilenoglicol (PEG) (Peppas, 1996).

Desde a década de 60, numerosos estudos são apresentados por Hoffman, Rosiak e outros, no desenvolvimento de uma técnica de polimerização utilizando radiação gama proveniente de uma fonte de Cobalto 60 (Széliga \& Bregni, 2001).

A reticulação por radiação ionizante dá-se pela formação de radicais poliméricos. Quando a irradiação ocorre em meio aquoso ocorre a radiólise, a qual produz espécies reativas, como os radicais hidroxila, que abstraem os átomos de hidrogênio das moléculas poliméricas, formando macrorradicais (FIG. 5) (Rosiak \& Ulanski, 1999). Exemplos de polímeros reticulados por esse processo incluem PVP, PVA e PEG (Satish et al., 2006). 


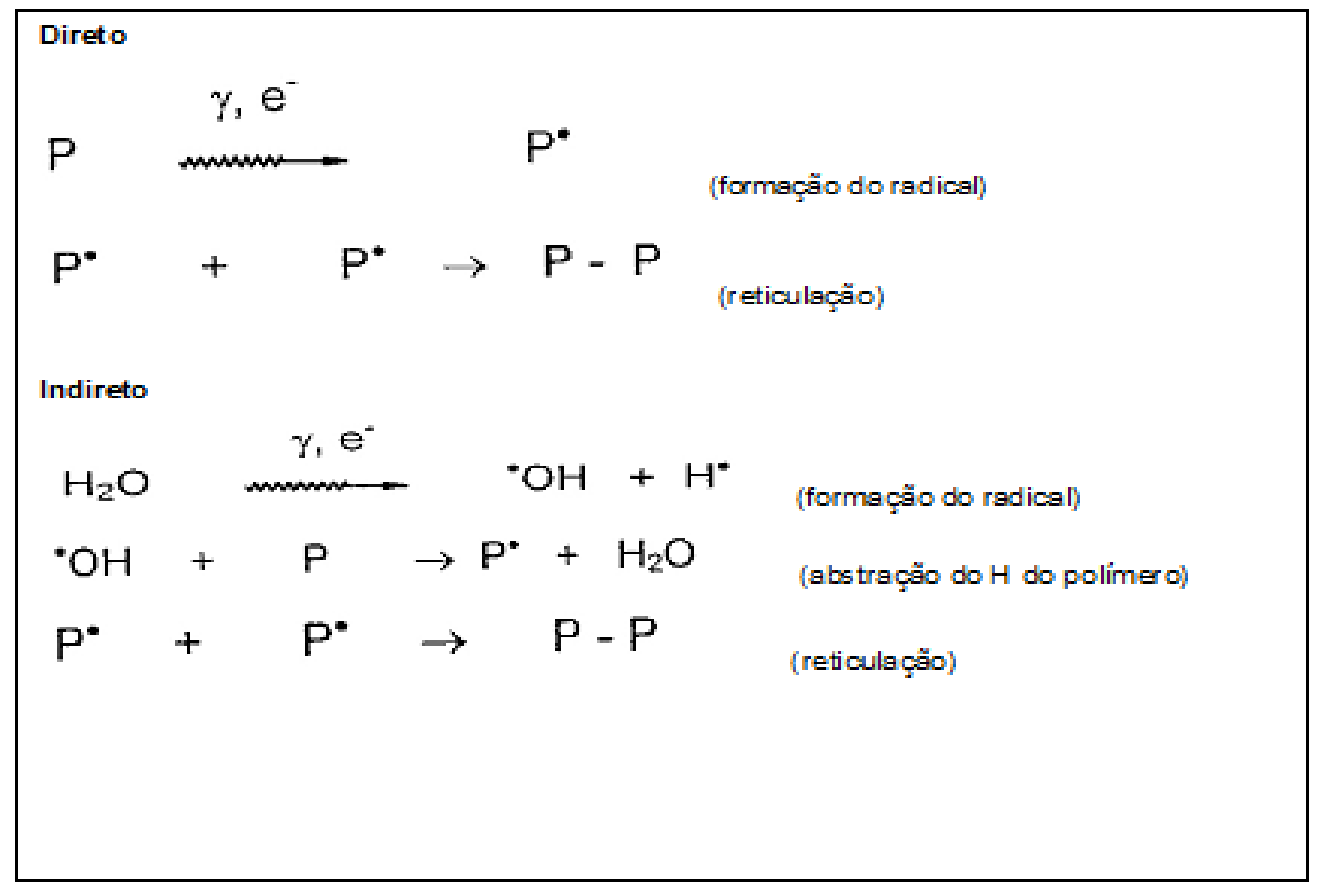

FIGURA 5 - Mecanismo simplificado da formação do radical polimérico, por meio de radiação ionizante

A reticulação de hidrogéis por meio da radiação ionizante é resultado da interação dos macrorradicais formados na cadeia polimérica que formam ligações covalentes e originam a rede polimérica (Rosiak \& Ulanski, 1999).

Quando obtidos por meio de radiação ionizante, os hidrogéis possuem as seguintes vantagens de processo: ausência de catalisadores e/ou iniciadores químicos que gerem toxicidade ao sistema; possibilidade de reações à temperatura ambiente ou mesmo a baixas temperaturas, se o sistema for refrigerado; possibilidade de controle de processo do início ao fim da irradiação; se a irradiação for realizada em sistema fechado, podem-se iniciar as reações e esterilizar o sistema de forma simultânea (Rosiak et al., 1995; Peppas et al., 2000).

Fatores como concentração do polímero em solução, taxa de dose e dose total de irradiação, presença de oxigênio e aditivos químicos possuem um forte impacto no processo de reticulação (Wach et al., 2001), o qual influencia diretamente na capacidade de intumescimento do hidrogel. Quando altamente reticulados, os hidrogéis apresentam uma estrutura mais apertada diminuindo o grau de intumescimento em comparação com hidrogéis menos reticulados. A 
reticulação diminui a mobilidade da cadeia polimérica, por isso diminui a capacidade de intumescimento do hidrogel (Peppas et al., 2000).

Os polímeros são uma das classes de materiais mais versáteis, possuem importantes aplicações na área médica, agricultura e engenharia. $O$ primeiro polímero utilizado como biomaterial foi o poli(metacrilato de metila). Já o poli(metacrilato de 2-hidroxietila) foi utilizado como hidrogel na década de 1960 por Wichterle e Lim (apud Satish et al., 2006; Hamidi et al., 2008). Os hidrogéis despertaram grande interesse para as ciências biomédicas por possuírem propriedades físicas semelhantes as dos tecidos vivos, como conter grande quantidade de água, consistência macia e baixa tensão superficial com a água ou outros fluidos biológicos (Satish et al., 2006).

Para serem utilizados como biomateriais devem cumprir algumas exigências (Rosiak et al., 1995):

- Não apresentar toxicidade, ser apirogênico e não ser cancerígeno;

- Ser funcional, podendo permanecer temporária ou definitivamente no organismo;

- Ser estéril;

- Biocompatibilidade, ou seja, não causar danos as células do organismo.

Por apresentarem propriedades tais como biocompatibilidade e hidrofilicidade, os hidrogéis se tornam atrativos para uma variedade de aplicações farmacêuticas e biomédicas, tais como: lentes de contato, curativos, cartilagem, pele artificial, material de reconstrução maxilofacial e de órgãos genitais, tendões artificiais, cordas vocais, entre outras (Peppas, 1996).

São utilizados como curativos de uso tópico por apresentarem as seguintes vantagens (Peppas, 1996; Rosiak et al., 1995; Rogero et al., 2003):

- Biocompatibilidade;

- Absorver esxudação; 
- Promover barreira contra micro-organismos;

- Permitir a permeabilidade do oxigênio;

- Permitir a incorporação e controlar a liberação de ativos;

- Acelerar o processo de cicatrização.

Nos processos de cicatrização, os hidrogéis são indicados para feridas secas ou com pouco exsudato, com necrose, feridas limpas e superficiais (como cortes e abrasões), úlceras diabéticas ou de pressão e em queimaduras de primeiro e segundo graus. Sua ação ocorre por amolecimento e remoção do tecido por meio de desbridamento autolítico. Possuem o benefício de serem utilizados em várias fases da cicatrização, não danificarem o tecido de granulação e promoverem alívio e conforto (Mandelbaum et al., 2003; Franco \& Gonçalves, 2008).

São também utilizados como carreadores de ativos em diversas partes do corpo por possuírem a capacidade de prolongar o tempo de permanência para liberação local (Peppas et al., 2000).

\subsubsection{Interação da radiação ionizante com a matéria e a sua ação em polímeros}

A química das radiações consiste nos efeitos químicos produzidos quando um material é exposto à radiação de alta energia ou à radiação ionizante. Os tipos de radiação mais conhecidos são os produzidos pelo decaimento do núcleo radioativo (radiações $\beta$ e $\gamma$ ), feixe de partículas reativas de alta energia (partículas $\alpha$, elétrons e prótons) e radiação eletromagnética de onda curta (raios x) (Spinks \& Woods, 1990).

As fontes de radiação mais frequentemente utilizadas nos estudos da química da radiação são as fontes $\gamma$ de cobalto-60 ou césio-137 e os aceleradores de elétrons (Spinks \& Woods, 1990). 
Quando fótons de alta energia interagem com a matéria, a maior parte da energia é absorvida pelo meio para ejetar elétrons do átomo do material (Spinks \& Woods, 1990). Os três principais processos de interação da radiação com a matéria são: efeito fotoelétrico, efeito Compton e a produção de pares (Chatterjee, 1987).

No efeito fotoelétrico, a energia inteira do fóton é absorvida completamente por um elétron atômico. A energia cinética desse fóton ejetado é igual à diferença entre a energia do fóton e a energia de ligação do elétron no átomo. Fótons de baixa energia interagem predominantemente pelo efeito fotoelétrico (Chatterjee, 1987; Spinks \& Woods, 1990).

O efeito Compton ocorre quando um fóton interage com um elétron, fracamente ligado ou livre, de modo que o elétron é acelerado e o fóton defletido com energia reduzida. Esse efeito ocorre predominantemente em fótons com energia entre 1 e $5 \mathrm{MeV}$, em materiais de com alto número molecular ou sobre uma carga muito forte de energia em materiais de baixo número molecular (Spinks \& Woods, 1990).

Já a produção de pares envolve a completa absorção do fóton nas redondezas de um núcleo atômico, ou, em menor frequência, de um elétron com a formação de duas partículas ou de um elétron com um pósitron. Esse processo não ocorre em fótons com energia menor do que 1,02 MeV (Spinks \& Woods, 1990).

Fontes de $\gamma$ de ${ }^{60}$ Co são frequentemente usadas como fontes de radiação ionizante, nas quais os fótons emitidos possuem energia de 1,332 e $1,173 \mathrm{MeV}$. Nesta energia, praticamente todas as interações ocorrem por meio do efeito Compton (Chatterjee, 1987; Spinks \& Woods, 1990).

A irradiação de polímeros visa modificar suas propriedades físicas, como propriedades mecânicas, condutividade, solubilidade e também sua estrutura química. Polímeros de cadeia linear, quando expostos à radiação de alta energia sofrem tanto cisão da cadeia como resultado de uma baixa força mecânica (FIG. 6), quanto reticulação, a qual pode melhorar suas propriedades mecânicas. A reticulação gera ligações cruzadas entre as cadeias poliméricas, e um aumento do peso molecular, como resultado tem a formação de uma rede tridimensional insolúvel (FIG. 7) (Spinks \& Woods, 1990; Rapado et al., 2003). 


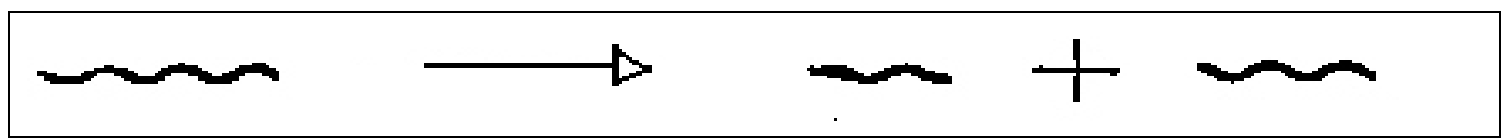

FIGURA 6 - Cisão da cadeia molecular dos polímeros expostos à radiação Fonte - Schnabel, 1981

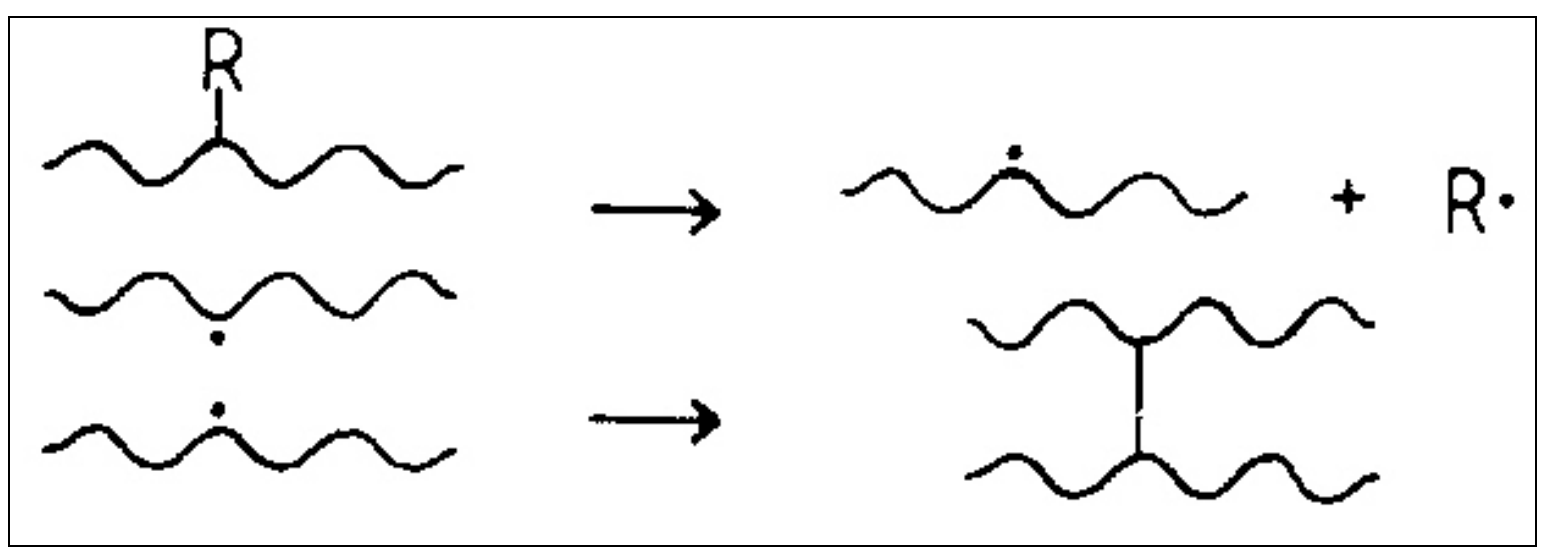

FIGURA 7 - Formação de ligações cruzadas, reticulação, de polímeros expostos à radiação

Fonte - Schnabel, 1981

O mecanismo mais aceito para a reticulação de polímeros por meio de radiação ionizante é a quebra de uma ligação $\mathrm{C}-\mathrm{H}$ de uma cadeia polimérica, expulsando um átomo de hidrogênio seguido da formação de um radical polimérico livre. Os radicais produzidos podem migrar pela cadeia e se unirem a outros, que se recombinam formando a ligação cruzada (Schnabel, 1981). A formação de ligações cruzadas e a cisão das cadeias podem acontecer de maneira individual ou simultânea, o que depende da estrutura química dos polímeros e de fatores externos, como a presença ou não de oxigênio (Charlesby, 1987).

\subsubsection{Hidrogéis de poli( $N$-vinil-2-pirrolidona)}

O PVP (FIG. 8) é um polímero sintético, constituído essencialmente da polimerização do $\mathrm{N}$-vinyl-2-pirrolidona, com peso molecular variando entre 2.500 (PVP K12) e 3.000.000 (PVP K120) (Kibbe, 2000). Anfotérico e altamente polar, é um pó solúvel em água e em alguns solventes orgânicos, possui boas 
características na formação de filmes (Barabas, 1989) e é considerado seguro para uso biológico (Hamidi et al., 2008).

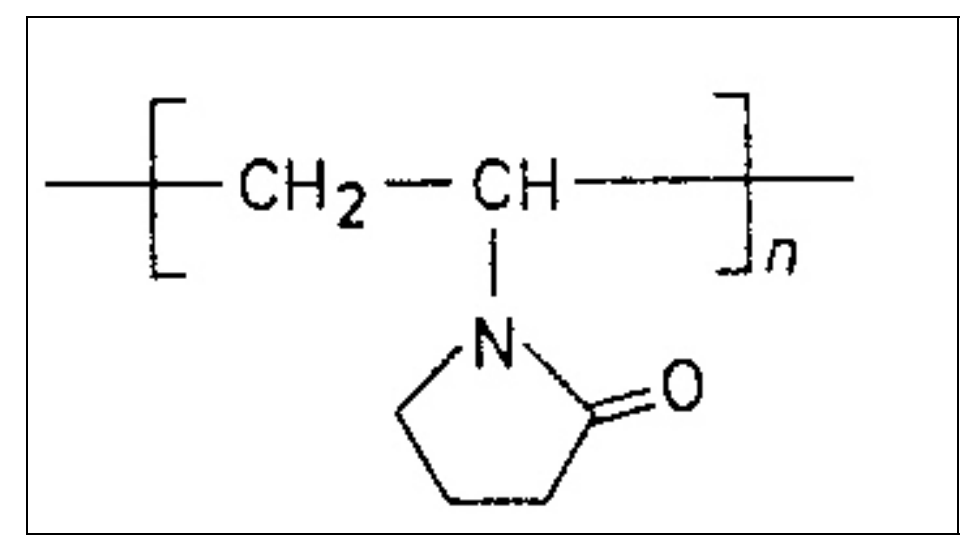

FIGURA 8 - Estrutura química do poli(N-vinil-2-pirrolidona)

É utilizado em uma ampla variedade de formulações farmacêuticas, como desintegrante, agente de suspensão, estabilizante e/ou doador de viscosidade, em comprimidos, soluções ou suspensões orais e tópicas (Kibbe, 2000). Além disso, é utilizado em curativos para feridas e sistemas de liberação de ativos (Ajji et al., 2005).

Os primeiros curativos de hidrogel à base de PVP, PEG e ágar foram desenvolvidos por Rosiak e colaboradores em 1989 para o tratamento de queimaduras, e comercializados com o nome de Aqua Ge ${ }^{\circledR}$. Desde então, vários estudos têm sido realizados utilizando o PVP.

Miranda e colaboradores (1999) avaliaram a fração gel e o intumescimento de hidrogéis de PVP, PEG e ágar, quando formulados com diferentes concentrações de $\operatorname{PVP}(2,5,8,10,12$ e 16\%) e submetidos à diferentes doses de irradiação $(15,20,25$ e $30 \mathrm{kGy})$. Os resultados mais homogêneos de reticulação foram obtidos nos hidrogéis com 5\% de PVP, submetidos às doses entre 20 e $30 \mathrm{kGy}$.

Um estudo realizado por Feldstein et al. (1996) avaliou a liberação de propranolol, trinitrato de glicerina e dinitrato de isossorbida por meio de sistemas de liberação transdérmicos, constituídos por hidrogéis de PVP e poli( óxido de etileno) (PEO). Foi observada a compatibilidade desses dispositivos com ativos de diferentes estruturas químicas, mesmo em altas concentrações (10 a 20\%). A 
cinética de liberação in vitro demonstrou que 75 a $85 \%$ da liberação ocorrem por meio de difusão.

Sen e Guven (1999) prepararam hidrogéis de PVP e hidrogéis de PVP com ácido itacônico (PVP/IA) para liberação de azul de metileno, obtendo melhores resultados com os hidrogéis PVP/IA, devido ao aumento dos grupos ácidos, que resultaram numa melhor capacidade de intumescimento.

O uso de matrizes poliméricas de PVP, PEG e ágar também se mostraram adequadas como sistema de liberação controlada de estradiol, um potente estrogênio endógeno (Rogero et al., 2002)

Abad e colaboradores (2003) estudaram uma blenda de PVP e Kcarregeenana (KC), um polímero hidrofílico e aniônico, e observaram que o KC age como um inibidor de reticulação, uma vez que compete com o PVP pelos radicais livres, o que diminui a fração gel do hidrogel. Observaram também que a incorporação do KC pode melhorar a capacidade de intumescimento do hidrogel, apresentando melhores resultados quando comparados ao do hidrogel de PVP _ ágar.

A utilização de radiação ultravioleta para a reticulação de hidrogéis, como alternativa a utilização de radiação $\mathrm{Y}$, foi estudada por Lopérgolo $\mathrm{e}$ colaboradores (2003), obtendo hidrogéis adequados para a utilização como curativos e sistemas de liberação de ativos.

Em 2005, Ajji e colaboradores avaliaram curativos a base de PVP, PEG e ágar, irradiados em raios $\mathrm{\gamma}$, na dose de 25 kGy. Verificaram que a adição de PEG reduz a fração gel do polímero, por agir como um plastificante além de diminuir a reticulação da matriz por ser um sequestrante de radicais livres. Efeito esse que é dose-dependente. Consequentemente, a adição de PEG aumentou o intumescimento das matrizes, bem como sua flexibilidade.

A interferência da adição de glicerina em hidrogéis de PVP, reticulados por radiação UV, foi estudada por D'Errico e colaboradores (2008), os quais observaram que a glicerina aumentou a fração solúvel do polímero e modificou suas propriedades mecânicas. A concentração ideal de glicerina encontrada para esses hidrogéis foi de $3 \%$, pois gerou um aumento a permeabilidade do hidrogel.

Amaral (2009) estudou a liberação do dipeptídio citrulil-arginina em hidrogéis de PVP e de PVA, obtendo uma melhor cinética de liberação nos hidrogéis de PVP. 


\subsection{Sistemas de liberação de ativos na pele}

A tecnologia de liberação controlada de ativos surgiu na década de 80 como uma alternativa para os sistemas de liberação tradicionais, para se obter uma melhor resposta com efeitos secundários mínimos e eficácia prolongada no organismo (Escobar et al., 2002).

$\mathrm{Na}$ tentativa de maximizar as vantagens inerentes às formas farmacêuticas de liberação modificada, ampla variedade de sistemas tem sido objeto de investigação. O principal objetivo desses sistemas de liberação é delinear substâncias ativas com penetrabilidade seletiva para incorporação em veículos ou dispositivos que liberam o mesmo em sítios ativos, em concentração e velocidade de liberação controlada, por um determinado tempo (Barry, 2005).

Devido a sua habilidade de intumescimento e de liberar substâncias para o meio, os hidrogéis são frequentemente utilizados como sistemas de liberação de ativos. Possibilitam ainda a proteção do ativo da influência de oxigênio ou de outros agentes degradantes quando em seu estado seco (Rosiak, 1994).

Uma grande variedade de polímeros é utilizada como sistema de liberação de substâncias, dos quais os derivados de celulose e os acrílicos apresentam boa aplicação como filmes transdérmicos (Oliveira \& Lima, 2006). Na maioria dos casos, um só monômero não proporciona ao mesmo tempo boas propriedades mecânicas e grande retenção de água (Escobar et al., 2002). A mistura de polímeros com diferentes propriedades permite um maior controle da liberação, conforme a necessidade requerida pelo sistema (Oliveira \& Lima, 2006).

Os principais polímeros utilizados nos sistemas de liberação estão representados na TAB. 4: 
TABELA 4 - Principais polímeros usados em sistemas de liberação de ativos

\begin{tabular}{l|l}
\multicolumn{1}{c}{ Classificação } & \multicolumn{1}{c}{ Polímeros } \\
\hline \hline Polímeros naturais & Colágeno, albumina, gelatina \\
\hline Polímeros à base de proteínas & $\begin{array}{l}\text { Agarose, alginato, ácido hialurônico, } \\
\text { dextrana, quitosana, ciclodextrinas }\end{array}$ \\
\hline Polissacarídeos & \\
\hline Polímeros sintéticos & $\begin{array}{l}\text { Poli(ácido láctico), poli(ácido glicólico), } \\
\text { poli(hidroxibutirato) }\end{array}$ \\
\hline Bodegradáveis & Poli-imino carbonatos, poliaminoácidos \\
\hline Poliamidas & Polifosfatos, polifosfonatos, polifosfazenos \\
\hline Polímeros fosforosos & Policianoacrilatos, poliuretanos, poliacetais \\
\hline Outros & $\begin{array}{l}\text { Carboximetilcelulose, etilcelulose, acetato } \\
\text { de celulose, hidroxipropilmetilcelulose }\end{array}$ \\
\hline Não biodegradáveis & Polidimetilsiloxano, sílica coloidal \\
\hline Derivados de celulose & $\begin{array}{l}\text { Polimetracrilatos, poli(metacrilato } \\
\text { metila) }\end{array}$ \\
\hline Silicones &
\end{tabular}

Fonte - Oliveira \& Lima, 2006.

Diversos ativos têm sido estudados usando como via de administração a pele. Sistemas de liberação de substâncias ativas na epiderme que maximizam o tempo de permanência na pele e minimizam a absorção transdérmica apresentam um importante papel no sucesso da terapia tópica local (Alencastre, et al., 2006).

Os ativos devem ser incorporados aos polímeros durante o seu processo de obtenção. Quando isso não for possível devido a o ativo interferir no processo de reticulação ou ser sensível ao processo, esse deve ser incorporado pelo processo de intumescimento com o ativo solubilizado na solução (Rosiak, 2004).

De uma maneira geral, os dispositivos poliméricos usados na liberação de ativos podem ser classificados como controlado por difusão (dispositivos 
monolíticos ou controlados por membrana), controlados pela penetração de água (intumescimento ou osmose) ou quimicamente controlados (biodegradáveis) (Liechty et al., 2010; Heller, 1996), conforme observado na TAB. 5:

TABELA 5 - Classificação dos sistemas de liberação controlada.

\begin{tabular}{l|l}
\multicolumn{1}{c}{ Tipos de sistema } & \multicolumn{1}{c}{ Mecanismo de liberação } \\
\hline Controlado pela Difusão & \multicolumn{2}{l}{ Difusão através da membrana. } \\
\hline Dispositivos reservatórios & Difusão através do corpo do polímero. \\
\hline Dispositivos monolíticos & $\begin{array}{l}\text { Transporte osmótico da água por meio de } \\
\text { uma membrana semipermeável. }\end{array}$ \\
\hline Controlado pela Penetração de Água & $\begin{array}{l}\text { Penetração de água em um polímero } \\
\text { seco. }\end{array}$ \\
\hline Sistema osmótico & $\begin{array}{l}\text { Por erosão ou pela combinação de } \\
\text { erosão com difusão. }\end{array}$ \\
\hline Sistema por intumescimento & $\begin{array}{l}\text { Combinação entre a hidrólise do grupo } \\
\text { pendente e a difusão do corpo do } \\
\text { polímero. }\end{array}$ \\
\hline Sistemas monolíticos & \\
\hline Sistemas de cadeias laterais (enxertos
\end{tabular}

Fonte - Heller, 1996.

Nos sistemas monolíticos, o ativo é disperso na matriz polimérica e a liberação é controlada pela difusão da matriz (FIG. 9). Nesse caso, a difusão depende da solubilidade do ativo e como ele está dissolvido no polímero. Nos dispositivos controlados por membrana, o ativo está contido em um compartimento que é envolto por uma fina membrana polimérica e a liberação para o meio ocorre por difusão do ativo para o meio externo, a qual é limitada pela membrana (Heller, 1996). 


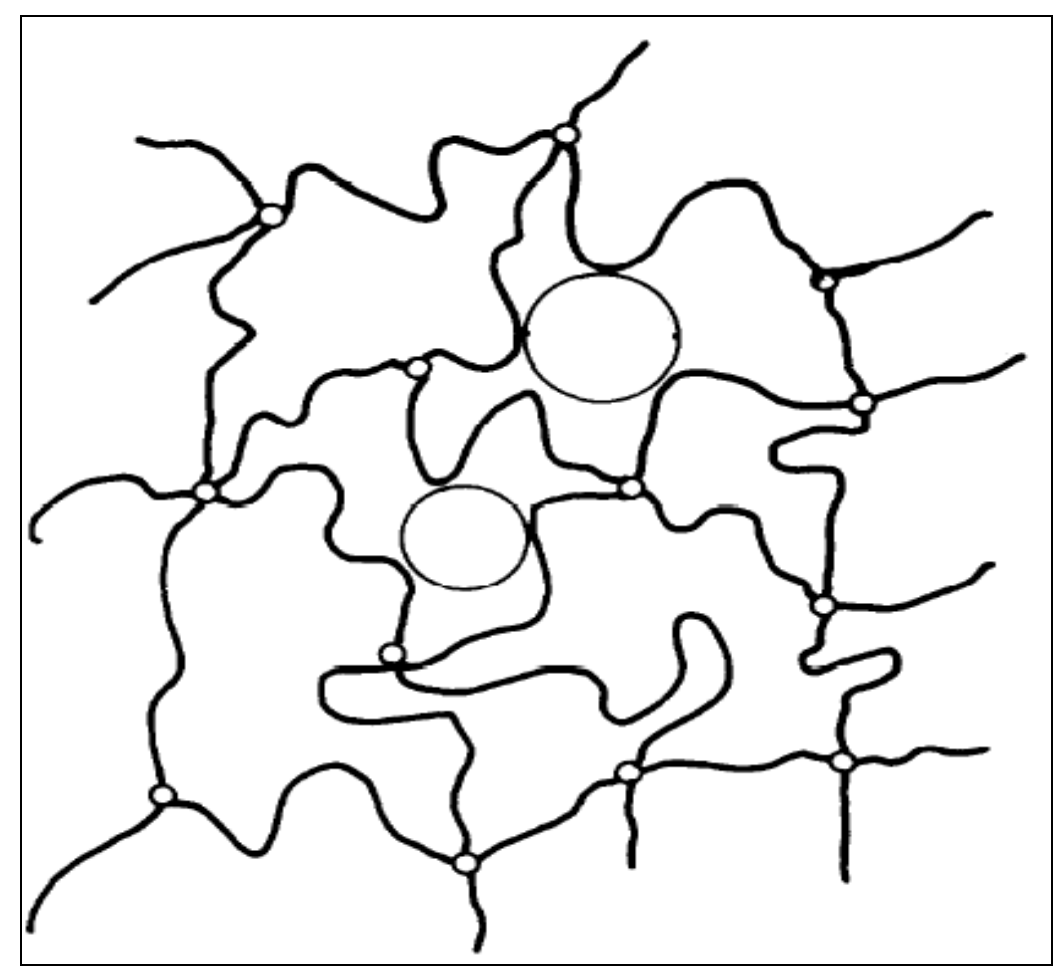

FIGURA 9 - Representação da cadeia macromolecular reticulada Fonte - Langer \& Peppas, 1981.

Os sistemas controlados pela penetração da água caracterizam-se por ter o ativo disperso numa matriz hidrofílica, que ao receber água do meio externo intumesce e libera o ativo por difusão (FIG. 10) (Heller, 1996).

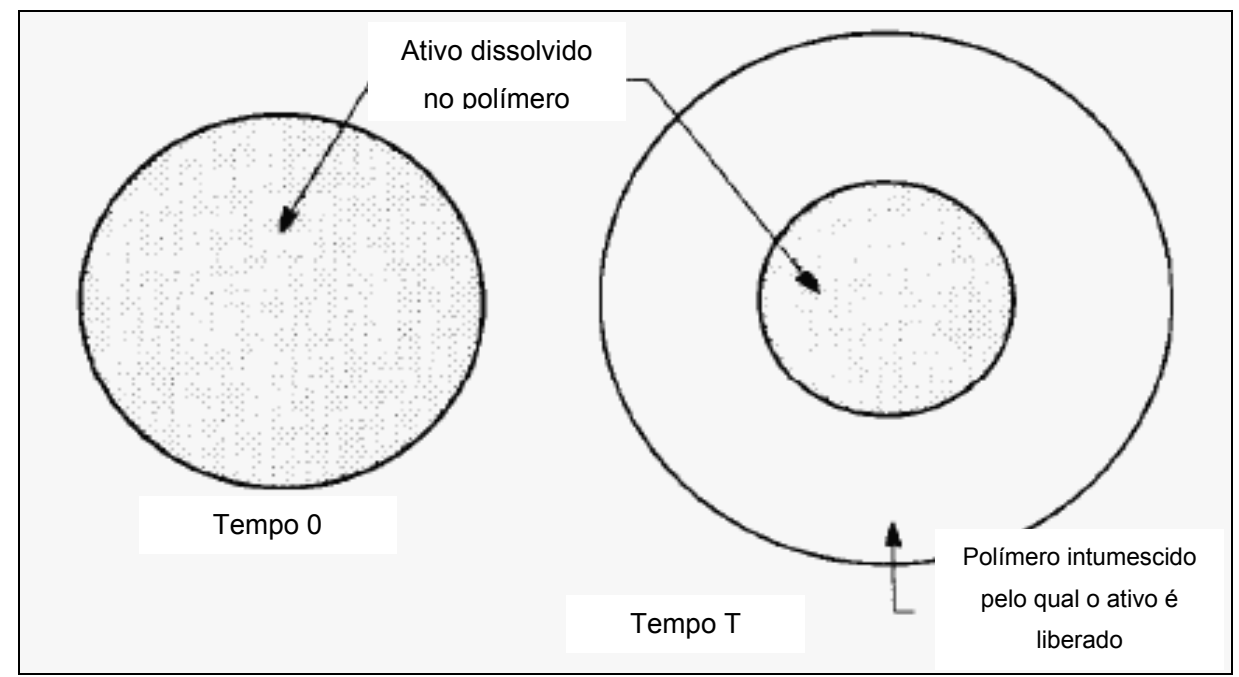

FIGURA 10 - Sistema de liberação controlada por intumescimento Fonte - Langer \& Peppas, 1981. 
Já nos sistemas quimicamente controlados, a liberação ocorre pela degradação do polímero, por meio de reações químicas que ocasionam erosão do polímero (Heller, 1996).

A liberação de ativos pelos dispositivos de hidrogéis depende de dois processos simultâneos: migração da água para dentro do dispositivo e difusão do fármaco através do gel intumescido (Peppas, 1996; Rosen, 2005). Nesse caso, os dispositivos entram em contato com o organismo e absorvem os fluidos biológicos até intumescerem. O intumescimento aumenta o volume aquoso dentro do dispositivo assim como o seu tamanho tridimensional, permitindo que a substância se difunda através da rede intumescida para o meio externo (Escobar et al., 2002). Na difusão, a liberação é controlada pela taxa de degradação do polímero, assim quanto mais próximo da superfície a substância estiver, mais rapidamente será liberada (Rosiak et al., 1995).

Quando moléculas individuais se movem a partir de uma substância, a difusão ocorre como resultado de um gradiente de concentração ou pelo movimento molecular aleatório (Allen Júnior, 2007; Barry, 2005). Na difusão passiva ocorre a passagem das moléculas através de uma membrana que não participa ativamente do processo. A liberação é comandada pelo gradiente de concentração, ocorrendo primariamente a partir do local de maior concentração. $A$ maioria das substâncias atravessa as membranas biológicas por esse processo (Allen Júnior, 2007).

Alguns fatores externos podem influenciar no intumescimento dos hidrogéis, como a temperatura, o pH, força iônica, entre outros (Escobar et al., 2002), consequentemente, na taxa de liberação de ativos. O grau de reticulação, a composição química dos hidrogéis e a solubilidade do ativo também podem interferir no processo de liberação de ativos (Rosiak et al., 1995). Deve-se considerar também que propriedades como hidrofilicidade, lubrificação, adesão e solubilidade, determinam tanto a biocompatibilidade quanto as propriedades físicas e de intumescimento dos hidrogéis (Oliveira \& Lima, 2006).

São características ideais dos sistemas de liberação controlada: não apresentar toxicidade para a pele e cabelo, penetrar profundamente ou superficialmente e permitir a fácil manipulação de ativos líquidos ou sólidos. Em geral, também possuem a propriedade de proteger ativos sensíveis da oxidação e interação com outros componentes da fórmula (Rosen, 2005). 
A utilização de matrizes poliméricas é uma das estratégias mais empregadas no desenvolvimento de formulações de liberação modificada devido a vantagens como versatilidade, eficácia, baixo custo, além de permitir a incorporação de quantidades relativamente elevadas de substâncias ativas (Lopes et al., 2005).

\subsection{Biocompatibilidade}

Para o uso de um biomaterial, dois critérios devem ser avaliados: a biofuncionalidade e a biocompatibilidade durante todo o tempo em que o material permanecer no corpo. A biofuncionalidade refere-se à desempenho do material. Já a biocompatibilidade é a habilidade de o material permanecer inerte no organismo, o que é avaliado em termos de toxicidade (Autian, 1977). O material em contato com o organismo não deve apresentar uma resposta adversa, não pode ser afetado pelo meio fisiológico e os tecidos não podem ser danificados pela sua presença (Ratner, 1996).

A seleção e avaliação de um material para uso em humanos requer que haja um programa estruturado de avaliação, considerando as vantagens e desvantagens de cada processo. Para assegurar que o produto final é seguro para uso humano, o programa deve incluir uma avaliação biológica (ISO 10993-5, 1992).

\subsubsection{Citotoxicidade}

O teste de citotoxicidade in vitro é o primeiro teste realizado para verificar a biocompatibilidade de uma grande variedade de elastômeros, polímeros e outros materiais médicos (Hanson et al., 1996).

Os estudos realizados nos últimos anos vêm demonstrando que se um material não for considerado citotóxico pelo método in vitro, também não será pelo método in vivo. Isso não significa necessariamente uma regra, mas sim a boa relação entre os dois métodos. A avaliação in vitro fornece dados rápidos e baratos, além de minimizar o uso de animais na pesquisa (Hanson et al., 1996). 
Técnicas de cultura de células são utilizadas, nas quais a amostra é colocada direta ou indiretamente em contato com a cultura de células, e verificase se houve alterações celulares, como lise (morte) celular, inibição do crescimento de células e outros efeitos causados pelos materiais ou seus extratos (ISO 10993-1, 1992). Além da amostra, é utilizado um controle negativo, ou seja, um material que não produz resposta biológica, e um controle positivo, o qual reproduz uma resposta citotóxica. Esse teste é o mais sensível, e essa sensibilidade depende diretamente da linhagem celular, do tipo de aplicação dos materiais e da interpretação da resposta (ISO 10993-5).

Um dos métodos mais utilizados para a determinação de citotoxicidade in vitro é o de incorporação do vermelho neutro, no qual a toxicidade é avaliada por meio da determinação da viabilidade celular, calculada pela quantidade do corante vermelho neutro incorporado às células vivas (Finter, 1969).

Após a determinação da citotoxicidade, outros testes podem ser realizados para determinar o perfil da biocompatibilidade do material, como interações com o sangue, irritação primária e sensibilização cutânea, entre outros (Hanson et al., 1996).

\subsubsection{Irritação cutânea primária}

Os biomateriais têm sido largamente estudados como curativos, pelo seu poder de acelerar o processo de regeneração do tecido epitelial, evitando a sua desidratação. Assim o seu poder de poder de causar danos à pele deve ser considerado (Hanson et al., 1996).

Testes em animais são utilizados para simular o ambiente que pode ser encontrado nos seres humanos. O primeiro passo para desenvolver um modelo ideal de análise é a escolha adequada do animal, o qual deve ser semelhante anatômica ou biologicamente as situações em humanos (Hanson et al., 1996).

Irritação cutânea é definida como uma resposta inflamatória localizada a uma substância pela aplicação única, repetida ou contínua, sem o envolvimento de um mecanismo imunológico (ISO 10993-10, 1996). Na avaliação da irritação cutânea primária estima-se o potencial irritante dos materiais ou de seus extratos, por meio da pele, olho ou mucosa em modelo experimental apropriado, após um 
único contato com o material. Seu desempenho depende da escolha da rota adequada e da duração da exposição ou contato para determinar os efeitos irritantes do material (ISO 10993-1, 1992).

O teste de irritação cutânea primária, desenvolvido por Draize e colaboradores (1946), utiliza o modelo in vivo em animais, no qual a amostra é colocada diretamente em contato com a pele intacta de coelhos, por $24 \mathrm{~h}$. Posteriormente avalia-se a formação de edema e de eritema causada por esse contato.

Essa avaliação em animais é útil na realização de uma análise comparativa e para predizer quais concentrações de determinada substância são toleradas pelo organismo. A relação entre animais e homens não é completa, entretanto os coelhos são sensíveis as irritações primárias tanto quanto o homem (Draize et al., 1946). Dentre os testes de segurança requeridos, esse deve ser aplicado aos dispositivos aptos para o uso (ISO 10993-10, 1996). 


\section{METODOLOGIA}

\subsection{Materiais}

\subsubsection{Matérias-primas}

- Poli(N-vinil-2-pirrolidona) (PVP) K 90 - BASF: pó branco, solúvel em água e em alguns solventes orgânicos, com massa molar ponderal entre 1.000 .000 e $1.500 .000 \mathrm{~g} / \mathrm{mol}$;

- Poli(etileno glicol) (PEG 300) - Oxiteno: líquido incolor e viscoso, solúvel em água, acetona, álcool, benzeno e glicerina, possui massa molar média entre 285 e $315 \mathrm{~g} / \mathrm{mol}$;

- Ágar tipo técnico $\mathrm{n}^{\circ} 3$ - Oxoid

- Glicerina (propano-2,3-triol) - Oxoid: líquido incolor, viscoso e higroscópico, solúvel em acetona, etanol e água, praticamente insolúvel em benzeno e clorofórmio;

- Óleo de açaí (Euterpe oleracea fruit oil) - Beraca Sabará: óleo extraído da polpa do açaí sem uso de solventes. Apresenta-se com um líquido viscoso, de cor amarelo esverdeado, com índice de acidez de 0,14\%, insolúvel em água;

- Estearato de glicerila (propano- 1,2,3-triol monoestearato) + Estearato de PEG 100 - Beraca Sabará: pérolas de cor branca para creme, dispersíveis em água.

- Ácido oleico 99,99\% - Vetec

\subsubsection{Reagente}

- Clorofórmio, grau HPLC - Labsynth. 


\subsubsection{Materiais}

- Microplacas de 96 poços;

- Vidrarias;

- Coluna capilar cromatográfica Carbowax 20 M - Varian;

- Coluna capilar cromatográfica DB-5 - Varian;

- Microseringas de $10 \mu \mathrm{L}$;

\subsubsection{Equipamentos}

- Balança analítica modelo BP121S- Sartorius;

- Seladora - Delgo;

- Extrator Soxhlet;

- Chapa de aquecimento - Quimis;

- Estufa de secagem modelo Q317M - Quimis;

- Cromatógrafo a Gás acoplado à Espectrômetro de Massas Quadrupolo, modelo QP 5050 - Shimadzu;

- Gammacell modelo 220 - Atomic Energy of Canada Limited Commercial Products;

- Estufa incubadora de CO2 modelo CB150- Binder;

- Espectrofotômetro leitor de microplacas, modelo Sunrise - Tecan;

- Incubadora modelo TE-420 - Tecnal;

- Liofilizador modelo dura-stop TDS3BOPT5000 - FTS systems;

- Microscópio eletrônico de varredura por emissão de campo modelo JSM 7401F - Jeol;

- Texturômetro, modelo TA-TX2i - Stable Micro System. 


\subsection{Métodos}

\subsubsection{Irradiação das amostras}

As amostras foram irradiadas em irradiador de Cobalto $60\left(\mathrm{Co}_{60}\right)$ Gammacell, modelo 220 (FIG. 11), localizado no Centro de Tecnologia das Radiações (CTR), do IPEN.

O irradiador Gammacell 220 é composto por duas câmaras, a primária que é fixa e envolta pela fonte de $\mathrm{Co}_{60}$, composta por 35 lápis de aço inox com sete pastilhas de $\mathrm{Co}_{60}$ em cada lápis (FIG. 12), e a câmara secundária ou câmara de irradiação, onde são colocadas as amostras a serem irradiadas. A câmara de irradiação é cilíndrica e móvel, e se encaixa no centro da câmara primária durante a irradiação. A câmara primária, ao envolver toda a câmara secundária, permite que ocorra uma irradiação homogênea da amostra (informação verbal $\operatorname{Dr}^{\mathrm{a}}$. Célia Marina Napolitano).

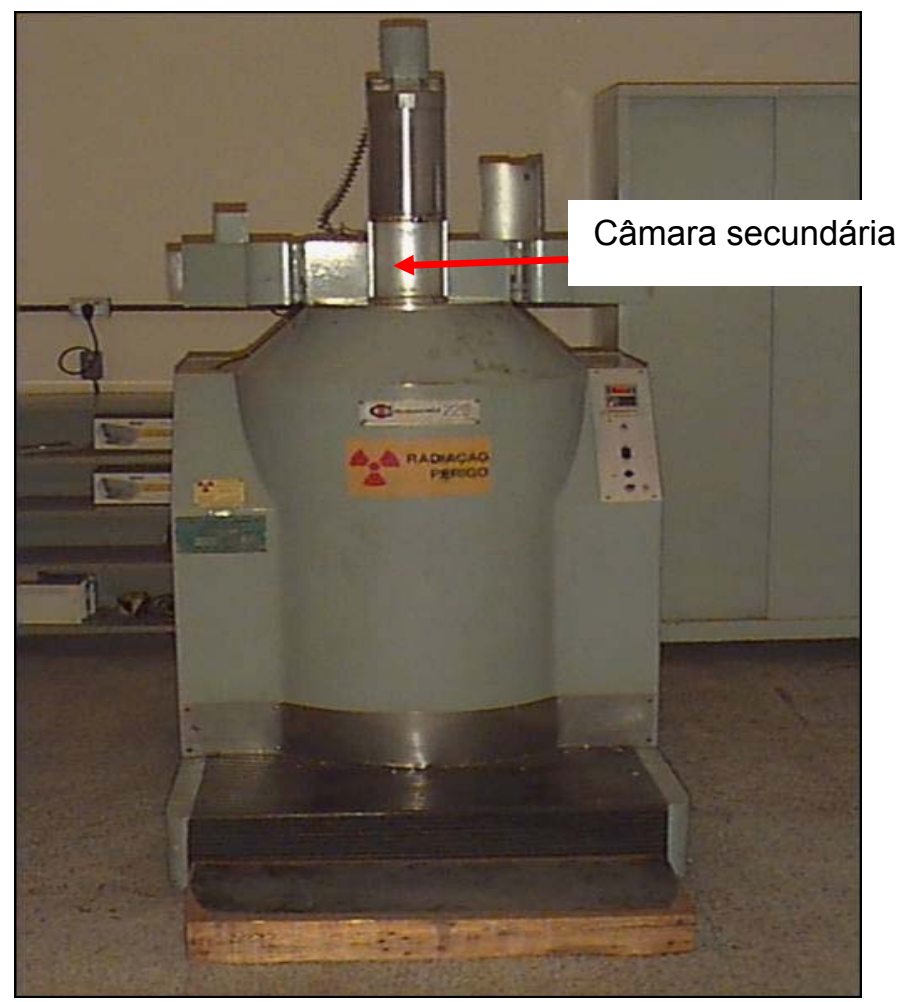

FIGURA 11 - Irradiador de ${ }^{60}$ Co do tipo Gamacell 220 


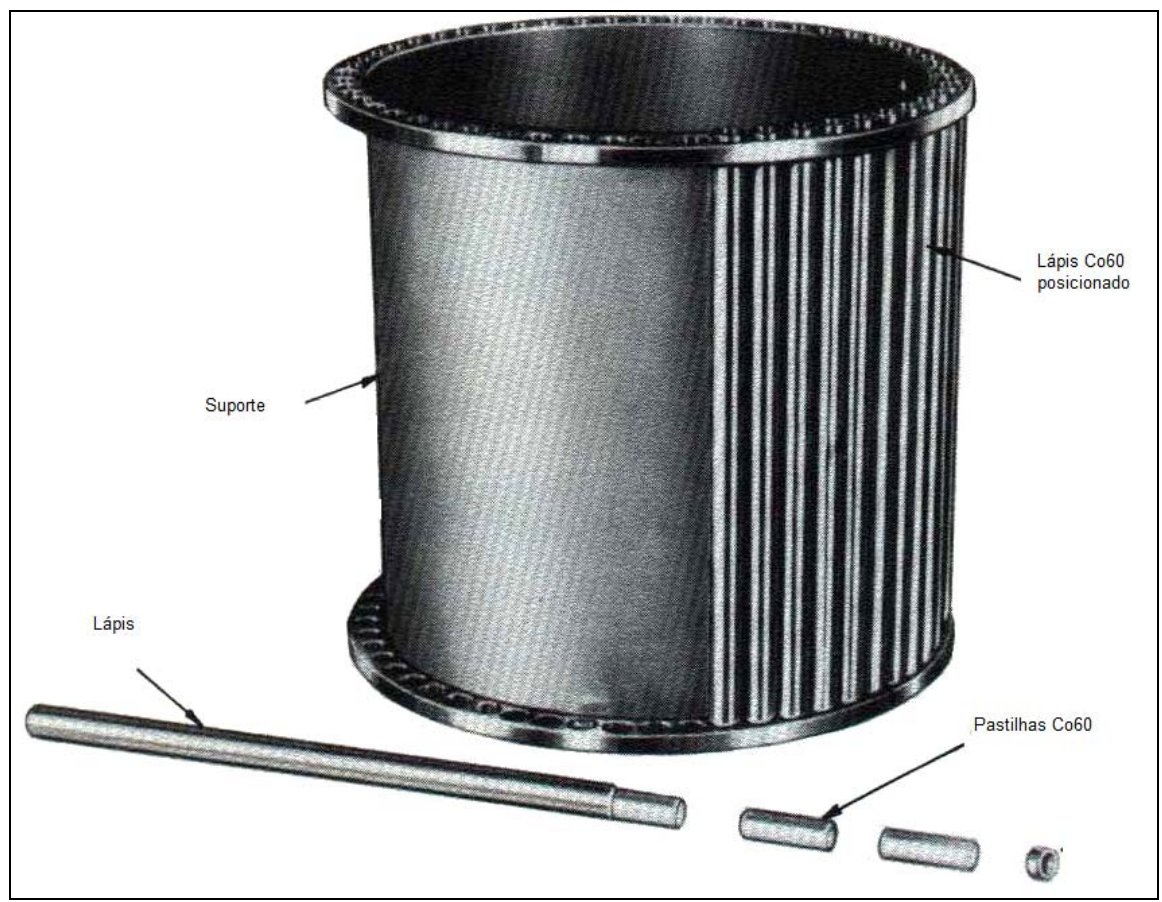

FIGURA 12 - Suporte contendo fontes de $\mathrm{Co}_{60}$

O irradiador Gammacell 220 do CTR foi recarregado em 1997 pela empresa J. L. Shepherd Associates, a qual forneceu uma curva de isodose, especificando as regiões da câmara de irradiação que podem receber dose de radiação acima ou abaixo da dose desejada. Assim, conforme a curva fornecida, o centro da câmara de irradiação recebe $100 \%$ da dose de radiação esperada, enquanto que, nas paredes laterais (mais afastadas do centro), a dose pode chegar a $115 \%$, e nas paredes superior ou inferior a $80 \%$ da dose desejada (informação verbal Eng ${ }^{\circ}$ Carlos G. da Silveira).

O Laboratório de Dosimetria do CTR realiza anualmente a averiguação da taxa de dose do irradiador por meio do dosímetro de Fricke, que é um dosímetro de referência com qualidade metrológica. Esse dosímetro é posicionado no centro da câmara secundária e a irradiação é realizada durante um tempo pré-determinado. Ao término da irradiação é realizada uma análise quantitativa em espectrofotômetro, que permite verificar a dose recebida em função do tempo, determinando assim a taxa de dose do irradiador. Para confirmar que todos os parâmetros estão de acordo é realizada uma "intercomparação" das medidas determinadas no IPEN com o laboratório da Agência Internacional de Energia Atômica (AIEA), na qual um dosímetro de transferência 
(dosímetro de alanina) é enviado pela AIEA e é irradiado na mesma posição e durante o mesmo tempo que o dosímetro de Fricke. Após irradiação o dosímetro de transferência retorna a AIEA e os dados obtidos são comparados com os do IPEN (informação verbal Dra. Célia Marina Napolitano). Periodicamente utilizamse também dosímetros de rotina para um mapeamento da dose recebida pela amostra, como parte de controle de qualidade do processo de irradiação.

Por meio da taxa de dose (kGy/h) apresentada pelo Gammacell foi calculado o tempo para que as amostras recebessem a dose desejada (15 ou 25 $k G y$ ), para isso todas as amostras foram posicionadas no centro da câmara de irradiação. A taxa de dose foi de 2,36 kGy/h.

\subsubsection{Determinação dos efeitos da radiação no óleo de açaí}

As matrizes de hidrogel são reticuladas por meio de radiação gama. Desconhecendo-se o comportamento do óleo de açaí mediante esse processo, realizou-se um teste preliminar de estabilidade, no qual o óleo de açaí foi submetido à radiação na dose total de $25 \mathrm{kGy}$. A dose total que os dispositivos foram submetidos foi de $15 \mathrm{kGy}$, entretanto conforme a avaliação das propriedades mecânicas, determinadas tátil e visualmente, que a interação com a radiação pudesse gerar, essa dose poderia chegar a até $25 \mathrm{kGy}$. Assim, o óleo de açaí foi irradiado na dosagem máxima pré-estabelecida para esse estudo.

O óleo de açaí foi acondicionado em frasco de PVC e enviado para irradiação em fonte de ${ }^{60} \mathrm{Co}$. Avaliaram-se os ácidos graxos presentes antes e após a exposição à radiação gama, pelo método de cromatografia a gás acoplada a espectrômetro de massas quadrupolo - (CG/EM) (FIG. 13). 


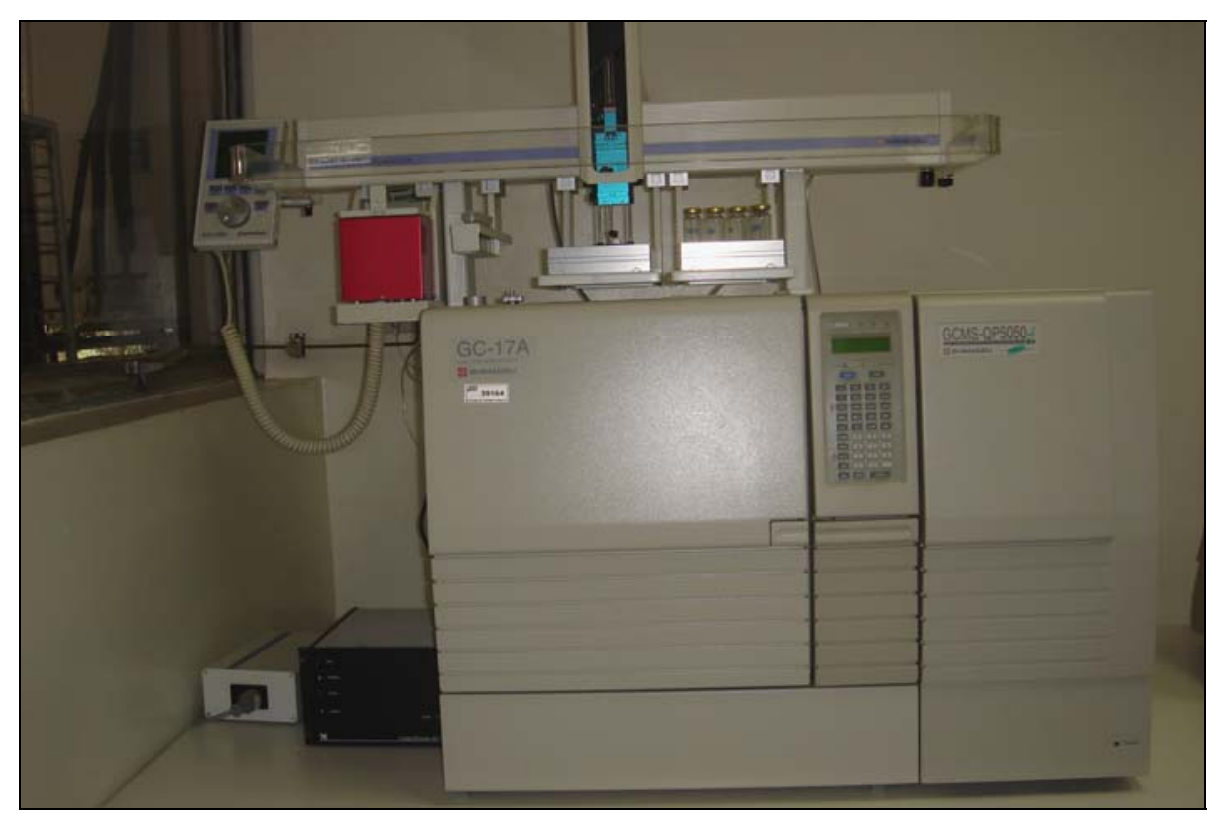

FIGURA 13 - Cromatógrafo a gás acoplado ao espectrômetro de massas, modelo QP 5050, da Shimadzu

$\mathrm{Na}$ cromatografia a gás, os compostos a serem separados são volatizados e por meio de um gás inerte (fase móvel), passam pela coluna onde um líquido de alta ebulição (fase estacionária) é depositado em um suporte sólido. As substâncias são separadas conforme os seus coeficientes de partição, que são dependentes das suas volatilidades e solubilidades na fase líquida (Martins et al., 2002). Na espectrometria de massa quadrupolo, o analisador de massas filtra os íons e os separam com base na sua relação massa/carga (m/z), gerada por meio da estabilidade de suas trajetórias por um campo elétrico criado por oscilações elétricas nos cilindros metálicos presentes, onde são aplicados uma corrente elétrica e uma rádio frequência. Apenas os íons de uma particular massa/carga terão uma trajetória estável e chegarão ao detector. A rádio frequência é variada para que os íons de diferente massa/carga obtenham uma trajetória estável, chegando ao detector e gerando assim um espectro de massas (Analisadores de massas quadrupolos, 2010).

Para a extração dos ácidos graxos da amostra utilizou-se a extração líquido-líquido com o solvente clorofórmio grau HPLC. Foi pesada em balança analítica uma quantidade conhecida de óleo de açaí num béquer limpo e adicionou-se clorofórmio ao béquer atingindo desta forma a primeira diluição (Martins et al., 2002). A mistura foi agitada em banho de ultrassom por 10 minutos 
com o objetivo de extrair o máximo de ácidos graxos. A partir desta diluição, outras diluições em clorofórmio foram realizadas até atingir a concentração de 50 $\mu \mathrm{g} / \mathrm{mL}$ de óleo de açaí em clorofórmio. Uma alíquota desta diluição foi acondicionada em vials de vidro para análise via CG/EM.

Com o auxílio de uma microsseringa graduada introduziu-se $1 \mu \mathrm{L}$ do extrato no injetor do CG. O injetor está aquecido a temperatura de $250{ }^{\circ} \mathrm{C}$ e, dessa forma, a amostra é vaporizada e introduzida na coluna cromatográfica. A coluna capilar utilizada foi a DB-5 de $30 \mathrm{~m} \times 0,25 \mathrm{~mm} \times 0,25 \mu \mathrm{m}$ e, sua fase estacionária é composta de polidimetilsiloxana com $5 \%$ de fenila, portanto, considerada uma coluna levemente polar. O gás de arraste utilizado foi o hélio numa velocidade linear de $32 \mathrm{~cm} / \mathrm{s}$ (medido a $100{ }^{\circ} \mathrm{C}$ ). A programação da coluna realizou-se da seguinte forma: isotermia a $75{ }^{\circ} \mathrm{C}$ por 2 minutos; em seguida a temperatura foi elevada até $200{ }^{\circ} \mathrm{C}$ numa razão de $15{ }^{\circ} \mathrm{C} / \mathrm{min}$; novamente a temperatura foi elevada até $250{ }^{\circ} \mathrm{C}$ numa razão de $20{ }^{\circ} \mathrm{C} / \mathrm{min}$, e finalmente isotérmica a $250{ }^{\circ} \mathrm{C}$ durante 2 minutos, totalizando 23 minutos de eluição dos analitos por meio da coluna cromatográfica. Os espectros de massas foram obtidos no modo de ionização por impacto de elétrons com energia de $70 \mathrm{eV}$. A varredura das massas foi de $30 \mathrm{~m} / \mathrm{z}$ até $350 \mathrm{~m} / \mathrm{z}$ para a seleção das massas correspondentes às dos ácidos graxos. A identificação dos componentes voláteis foi feita por comparação dos espectros de massas e tempo de retenção com os existentes nas bibliotecas do sistema de dados NIST-92 e da literatura.

\subsubsection{Matrizes poliméricas}

\subsubsection{Obtenção das matrizes poliméricas}

Duas diferentes matrizes de hidrogel de PVP foram obtidas baseadas no método desenvolvido por Rosiak e colaboradores (1989), conforme descrito na TAB. 6. 
TABELA 6 - Composição das matrizes de hidrogel de PVP

\begin{tabular}{ccc}
\hline Matriz de hidrogel de PVP & Composição & Concentração (\%) \\
\hline \multirow{2}{*}{ A } & PVP K90 & 6,0 \\
& PEG 300 & 1,5 \\
& Ágar & 0,5 \\
& Água destilada (qsp) & 100,0 \\
\hline \multirow{2}{*}{ B } & PVP K90 & 20,0 \\
& Glicerina & 5,0 \\
& Água destilada (q.s.p) & 100,0 \\
\hline
\end{tabular}

A matriz A foi obtida pela mistura do PVP K90 com o PEG 300 e a água destilada, deixando o sistema polimérico intumescer por $24 \mathrm{~h}$. Separadamente, aqueceu-se o ágar dissolvido em $20 \%$ do volume total de água destilada até fervura. Adicionou-se à mistura anterior sob agitação constante até homogeneização.

A obtenção da matriz B ocorreu pela mistura de todos os componentes sob agitação até completa homogeneização e, em seguida, intumescimento por $24 \mathrm{~h}$.

Foram distribuídos $5 \mathrm{~mL}$ da formulação em moldes circulares de $5 \mathrm{~cm}$ de diâmetro e 0,2 cm de espessura, os quais foram selados com tampas de alumínio, embalados e enviados para irradiação em fonte de raios gama de ${ }^{60} \mathrm{Co}$ na dose total de $15 \mathrm{kGy}$.

\subsubsection{Fração gel}

As matrizes de hidrogel foram cortadas em quatro partes com peso semelhantes e secas em estufa a $50^{\circ} \mathrm{C}$ até peso constante. Após secas, foram acondicionadas em sacos de tecido não tecido e, em triplicata, foram submetidas à remoção da fração solúvel com água fervente durante $40 \mathrm{~h}$ em extrator Sohxlet, no qual o solvente (água) evapora e condensa sobre o material, promovendo a extração da fração solúvel. Decorrido o tempo, as matrizes foram novamente secas em estufa a $50^{\circ} \mathrm{C}$ até peso constante (ASTM D 2765-01, 2001 modificada). 


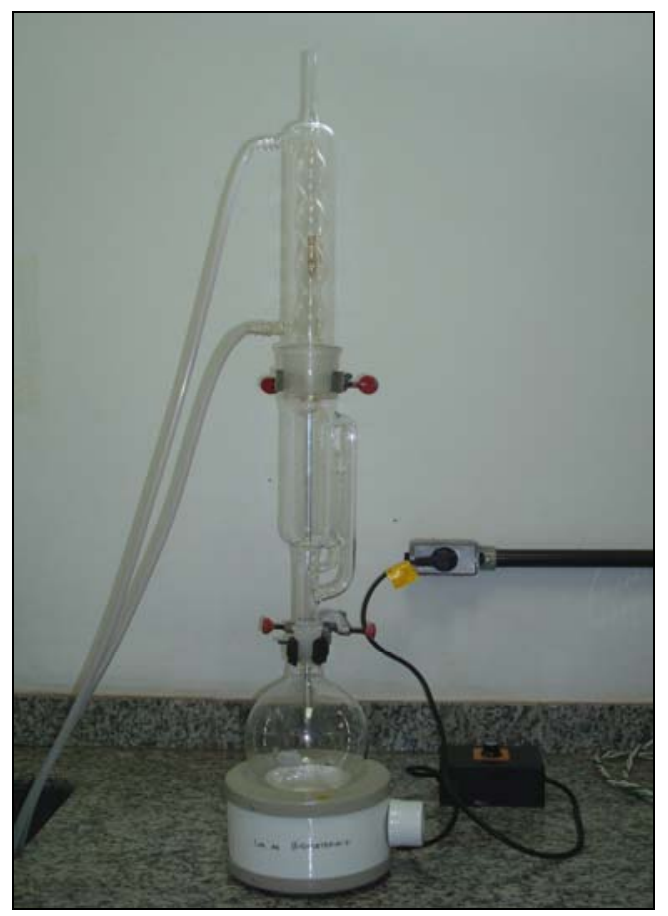

FIGURA 14 - Extrator Soxhlet com manta aquecedora

A fração gel foi calculada pela Equação (1), de acordo com a norma ASTM D 2765 -01 (2001).

$$
\text { Fração gel }(\%)=(\mathrm{mf} / \mathrm{mi}) \times 100
$$

\footnotetext{
Sendo:

$\mathrm{mi}=$ massa inicial da amostra desidratada

$\mathrm{mf}=$ massa final da amostra desidratada
}

\subsubsection{Intumescimento}

O intumescimento foi determinado pelo aumento de massa das matrizes de hidrogel em relação ao tempo de permanência com a solução. As matrizes de hidrogel foram cortadas em quatro partes de pesos aproximados e secas em estufa a $50{ }^{\circ} \mathrm{C}$ até peso constante. Cada amostra seca, em triplicata, foi imersa em $50 \mathrm{~mL}$ de solução salina tamponada com fosfato (PBS) $0,1 \mathrm{M} \mathrm{pH}=5,0$ em frascos de vidro fechados durante $24 \mathrm{~h}$. As amostras foram pesadas a cada hora, durante as primeiras 6 horas do ensaio e após 24 horas. A cada tempo, as 
amostras foram retiradas da solução com o auxílio de uma peneira e o excedente de solução na superfície da amostra foi removido com o auxílio de papel absorvente. Pôde- se então verificar a quantidade de solução absorvida pelas matrizes em cada período de tempo.

Para o cálculo do grau de intumescimento foi utilizada a Equação (2), de acordo com a norma ASTM D 570 (1998):

$$
\text { Intumescimento }(\%)=[(\mathrm{mf}-\mathrm{mi}) / \mathrm{mi}] \times 100
$$

$$
\begin{aligned}
& \text { Sendo: } \\
& \mathrm{mi}=\text { massa inicial do gel seco } \\
& \mathrm{mf}=\text { massa final do gel intumescido }
\end{aligned}
$$

\subsubsection{Propriedades mecânicas}

A força máxima de perfuração e a deformação das matrizes de hidrogel de PVP foram determinadas pelo ensaio de perfuração, utilizando o texturômetro modelo TA-TX2i, da Stable Micro Systems (FIG. 15), com probe de aço inoxidável com 7,9 mm de diâmetro. Utilizaram-se amostras, em triplicata, com $30 \mathrm{~mm}$ de diâmetro, fixadas em suporte com cavidade cilíndrica, nas quais o probe foi acionado na velocidade de penetração de $1 \mathrm{~mm} / \mathrm{s}$ (Sobral et al., 2001; Carvalho \& Grosso, 2006). A deformação foi calculada utilizando a Equação (3).

$$
D P=\Delta \mathrm{l} / \mathrm{lo}=\left\{\left[\left(D^{2}+\mathrm{lo}^{2}\right)^{0,5}-\mathrm{lo}\right] / \mathrm{lo}\right\} \times 100
$$

Sendo:

lo $=$ o comprimento inicial do corpo de prova (raio do círculo da amostra $=15 \mathrm{~mm}$ )

$\mathrm{D}=$ deslocamento do probe na perfuração. 


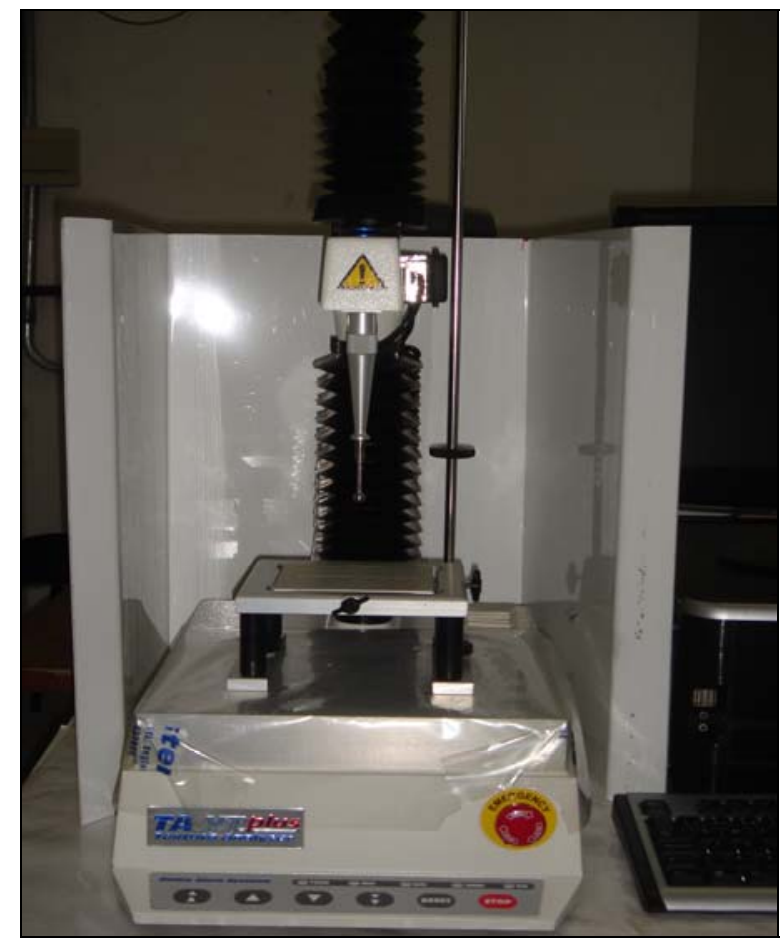

FIGURA 15 - Texturômetro, modelo TA-TX2i da Stable Micro System

\subsubsection{Citotoxicidade}

Para avaliar a citotoxicidade ou reatividade biológica das matrizes de hidrogel de PVP foi utilizado o teste in vitro de citotoxicidade utilizando o método de incorporação do vermelho neutro. Pellets de PVC (policloreto de vinila) atóxicos $\left(1 \mathrm{~cm}^{2} / \mathrm{mL}\right)$ foram usados como controle negativo; como controle positivo uma solução de fenol a $0,02 \%$.

De acordo com a norma ISO 10993-5, foram preparados extratos dos controles e das amostras, utilizando-se $1 / 8$ de cada hidrogel de PVP, equivalente a $4,5 \mathrm{~cm}^{2}$, imersos em $9 \mathrm{~mL}$ de meio mínimo de eagle (MEM), ou seja, $0,5 \mathrm{~cm}^{2} / \mathrm{mL}$ e incubados em estufa por $24 \mathrm{~h}$ a $37^{\circ} \mathrm{C}$. Diluições seriadas desses extratos (100\%, 50\%, 25\%\%, 12,5\% e 6,25\%) foram colocadas em uma microplaca de 96 poços (FIG. 16), contendo cultura células do tecido conectivo de camundongo, a linhagem NCTC clone L929, da American Type Culture Collection (ATCC), cultivadas em MEM e suplementado com 10\% de soro fetal bovino (SFB), 0,1 mM de aminoácidos não essenciais e $1 \mathrm{mM}$ de piruvato de sódio. Após o preparo, a microplaca foi colocada a $37^{\circ} \mathrm{C}$ por $24 \mathrm{~h}$ em estufa incubadora de $\mathrm{CO}_{2}$, modelo CB150, marca Binder, com atmosfera úmida e $5 \%$ de $\mathrm{CO}_{2}$. Esta etapa foi 
realizada em capela de fluxo laminar, com materiais estéreis e técnicas assépticas de manipulação.

O cultivo das células e a distribuição da suspensão celular na microplaca foram realizados na Seção de Culturas Celulares do Instituto Adolfo Lutz.

\begin{tabular}{|c|c|c|c|c|c|c|c|c|c|c|c|c|}
\hline & 1 & 2 & 3 & 4 & 5 & 6 & 7 & 8 & 9 & 10 & 11 & 12 \\
\hline A & $100 \%$ & $100 \%$ & $100 \%$ & $100 \%$ & $100 \%$ & $100 \%$ & $100 \%$ & $100 \%$ & $100 \%$ & $100 \%$ & $100 \%$ & $100 \%$ \\
\hline B & $50 \%$ & $50 \%$ & $50 \%$ & $50 \%$ & $50 \%$ & $50 \%$ & $50 \%$ & $50 \%$ & $50 \%$ & $50 \%$ & $50 \%$ & $50 \%$ \\
\hline C & $25 \%$ & $25 \%$ & $25 \%$ & $25 \%$ & $25 \%$ & $25 \%$ & $25 \%$ & $25 \%$ & $25 \%$ & $25 \%$ & $25 \%$ & $25 \%$ \\
\hline D & $12,5 \%$ & $12,5 \%$ & $12,5 \%$ & $12,5 \%$ & $12,5 \%$ & $12,5 \%$ & $12,5 \%$ & $12,5 \%$ & $12,5 \%$ & $12,5 \%$ & $12,5 \%$ & $12,5 \%$ \\
\hline$E$ & $6,25 \%$ & $6,25 \%$ & $6,25 \%$ & $6,25 \%$ & $6,25 \%$ & $6,25 \%$ & $6,25 \%$ & $6,25 \%$ & $6,25 \%$ & $6,25 \%$ & $6,25 \%$ & $6,25 \%$ \\
\hline$F$ & $\begin{array}{c}\text { MEM- } \\
\text { uso }\end{array}$ & $\begin{array}{l}\text { MEM- } \\
\text { uso }\end{array}$ & $100 \%$ & $50 \%$ & $25 \%$ & $12,5 \%$ & $6,25 \%$ & $100 \%$ & $50 \%$ & $25 \%$ & $12,5 \%$ & $6,25 \%$ \\
\hline G & $\begin{array}{c}\text { MEM- } \\
\text { uso }\end{array}$ & $\begin{array}{c}\text { MEM- } \\
\text { uso }\end{array}$ & $100 \%$ & $50 \%$ & $25 \%$ & $12,5 \%$ & $6,25 \%$ & $100 \%$ & $50 \%$ & $25 \%$ & $12,5 \%$ & $6,25 \%$ \\
\hline $\mathrm{H}$ & $\begin{array}{c}\text { MEM- } \\
\text { uso }\end{array}$ & $\begin{array}{l}\text { MEM- } \\
\text { uso }\end{array}$ & $100 \%$ & $50 \%$ & $25 \%$ & $12,5 \%$ & $6,25 \%$ & $100 \%$ & $50 \%$ & $25 \%$ & $12,5 \%$ & $6,25 \%$ \\
\hline
\end{tabular}

FIGURA 16 - Esquema da distribuição dos extratos das amostras e dos controles na microplaca

Legenda:

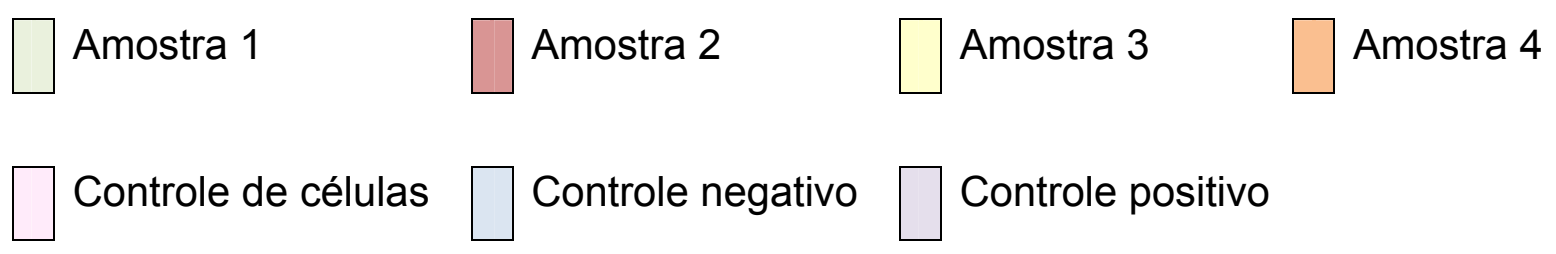

Depois de $24 \mathrm{~h}$, a microplaca foi retirada da estufa e os extratos foram substituídos por $200 \mu \mathrm{L}$ de solução do corante vermelho neutro e incubada novamente a $37^{\circ} \mathrm{C}$ por $3 \mathrm{~h}$ para incorporação do corante nas células. Decorrido este período, o corante foi desprezado e a microplaca lavada com solução tampão fosfato de $\mathrm{pH} 7,4$ e posteriormente com solução de lavagem $(1 \%$ de $\mathrm{CaCl}_{2} 10 \%$ em solução de formaldeído 0,5\%). Após a lavagem os poços, da microplaca foram preenchidos com $200 \mu \mathrm{L}$ de solução de extração (50\% de ácido acético $2 \%$ e etanol $50 \%$ ) para a lise das células vivas e liberação do corante. 
A viabilidade celular foi verificada pela quantificação do corante vital vermelho neutro adicionado no ensaio, por meio de leitura da densidade ótica, em espectrofotômetro leitor tipo ELISA da Tecan, em 540 nm.

\subsubsection{Dispositivo}

\subsubsection{Obtenção dos dispositivos}

Os dispositivos consistem nas matrizes de hidrogel de PVP com o óleo de açaí incorporado (TAB. 7). No dispositivo A1 foi adicionado o emulsionante estearato de glicerila + estearato PEG 100 para a incorporação do óleo à matriz, o que não foi necessário no dispositivo B1 devido à presença da glicerina, que pela sua característica anfifílica, permitiu a incorporação do óleo.

TABELA 7 - Composição dos dispositivos de hidrogel de PVP

\begin{tabular}{ccc}
\hline Matriz de hidrogel de PVP & Composição & Concentração (\%) \\
\hline A1 & PVP K90 & 6,0 \\
& PEG 300 & 1,5 \\
& Ágar & 0,5 \\
& Estearato de glicerila + & 0,4 \\
& Estearato PEG 100 & 1,0 \\
Óleo de Açaí & 100,0 \\
\hline Água destilada (qsp) & 20,0 \\
B1 & PVP K90 & 5,0 \\
& Glicerina & 1,0 \\
& Óleo de Açaí & 100,0 \\
\hline
\end{tabular}

O dispositivo A1 foi obtido pela mistura do PVP K90 com o PEG 300 e a água destilada, deixando o polímero intumescer por $24 \mathrm{~h}$. Decorrido o tempo de intumescimento, em outro béquer aqueceu-se o ágar com $20 \%$ da quantidade total de água destilada até fervura e completa dissolução. Separadamente 
preparou-se uma emulsão pela mistura e aquecimento (inferior a $50{ }^{\circ} \mathrm{C}$ ) do óleo de açaí com o emulsionante em $10 \%$ da água total. Juntaram-se as 3 fases sob agitação constante até completa homogeneização.

O dispositivo B1 foi obtido misturando-se o PVP K 90 com 50\% do volume total de água. Separadamente o óleo de açaí foi misturado à glicerina e incorporado à mistura inicial. A seguir, deixou-se a mistura total intumescer por 24 h. Decorrido o intumescimento, completou-se a quantidade de água.

Distribuíram-se $5 \mathrm{~mL}$ da formulação em moldes circulares de $5 \mathrm{~cm}$ de diâmetro e 0,2 cm de espessura, os quais foram selados com tampas de alumínio, embalados e enviados para irradiação em fonte de raios gama de $\mathrm{Co}_{60}$ na dose total de $15 \mathrm{kGy}$.

Após irradiação, os dispositivos foram caracterizados por meio dos testes de fração gel, intumescimento e alongamento. Para analisar a biocompatibilidade do dispositivo, realizou-se o teste de citotoxicidade in vitro; e, para avaliar o potencial de irritação na pele o teste de irritação cutânea primária in vivo. A microscopia eletrônica de varredura foi realizada para verificar a morfologia dos dispositivos e a cinética de liberação para quantificar o óleo de açaí liberado por meio dos dispositivos de hidrogel de PVP.

\subsubsection{Fração gel}

Realizado conforme descrito anteriormente, no item 4.2.3.2.

\subsubsection{Intumescimento}

Realizado conforme descrito anteriormente, no item 4.2.3.3.

\subsubsection{Propriedades mecânicas}

Realizado conforme descrito anteriormente, no item 4.2.3.4. 


\subsubsection{Citotoxicidade}

Realizado conforme descrito anteriormente, no item 4.2.3.5.

A ficha de segurança de produtos químicos, FISPQ n ${ }^{\circ} 0457$, referente ao óleo de açaí utilizado relata que a sua toxicidade aguda dermal (DL 50) é > $200 \mathrm{mg} / \mathrm{kg}$. Estudos demonstram que as matrizes de hidrogel não são citotóxicas, bem como a quantidade utilizada de óleo de açaí foi inferior à dosagem tóxica. Entretanto a interação entre os componentes do dispositivo e a radiação podem gerar substâncias tóxicas, sendo necessária a avaliação da toxicidade do produto final.

\subsubsection{Irritação Cutânea Primária}

O teste de irritação cutânea primária consiste na avaliação do potencial irritante do dispositivo na pele, por meio da observação e quantificação das reações que podem surgir após uma única aplicação do produto sobre a pele de coelhos. O óleo de açaí não produz irritação cutânea primária (Beraca Sabará, 2007), entretanto as suas interações com os componentes do dispositivo e a radiação também foram avaliadas.

Foram utilizados 6 coelhos da raça Nova Zelândia, macho e fêmea, com peso corpóreo acima de $2 \mathrm{~kg}$, sem lesões de pele. Os animais foram tricotomizados em duas áreas de $6,25 \mathrm{~cm}^{2}, 24 \mathrm{~h}$ antes do início do ensaio. Durante todo o período foram mantidos em gaiolas individuais, em salas com temperatura constante de $22 \pm 2{ }^{\circ} \mathrm{C}$ e umidade relativa entre 30 e $70 \%$. Para cada animal uma das áreas foi utilizada como controle e na outra foi aplicada $0,5 \mathrm{~g}$ de cada amostra. As áreas foram cobertas com compressas de gaze e afixadas com esparadrapo, depois foram protegidas por outra compressa de gaze envolvendo o corpo do animal. As amostras foram deixadas em contato com o animal durante 4 horas e em seguida removidas com água destilada. Realizou-se a leitura das áreas testadas após 24 e 72 horas do início do ensaio, avaliando-se a formação de eritema e edema (Draize et al., 1944; ASTMF 719, 1996; INCQS, 2007). 
O ensaio de irritação cutânea primária foi realizado no Instituto Adolfo Lutz, com os dispositivos A1 e B1.

A formação de eritema foi avaliada visualmente, de acordo com o Método de Draize (Draize, 1944), já para avaliar a formação de edema foi utilizado um paquímetro para medir a espessura da pele do animal dobrada longitudinalmente. $O$ cálculo do valor do edema é realizado pelas Equações (4) e (5):

$$
\text { e } \quad \begin{array}{ll}
E d(m m) & =\left(L_{24}-L_{i}\right) / 2 \\
E d(m m) & =\left(L_{72}-L_{i}\right) / 2
\end{array}
$$

Sendo:

Ed é o valor do edema, em milímetros

$\mathrm{L}_{24}$ é a medida da área teste na leitura de 24 horas

$\mathrm{L}_{i}$ é a medida da área teste antes da aplicação do produto

$\mathrm{L}_{72}$ é a medida da área teste na leitura de 72 horas

A graduação da intensidade das reações de eritema e edema é baseada no método de Draize e está relacionada nas TAB. 8 e 9 .

TABELA 8 - Graduação do eritema formado como reação cutânea

\begin{tabular}{ccc}
\hline $\begin{array}{c}\text { Grau de } \\
\text { reação }\end{array}$ & Reação & Características \\
\hline 0 & Pele normal & Pele geralmente de cor branca ou rósea \\
\hline 1 & Eritema leve & $\begin{array}{c}\text { Pele ligeiramente avermelhada, com tonalidade } \\
\text { diferente da área controle }\end{array}$ \\
\hline 2 & $\begin{array}{c}\text { Eritema bem } \\
\text { definido }\end{array}$ & Pele avermelhada, geralmente em toda área \\
\hline 3 & Eritema moderado & Pele com vermelhidão intensa e difusa \\
\hline 4 & Eritema severo & Pele vermelha escura, com formação de escara \\
\hline
\end{tabular}


TABELA 9 - Graduação do edema formado como reação cutânea

\begin{tabular}{ccc}
\hline $\begin{array}{c}\text { Grau de } \\
\text { reação }\end{array}$ & Reação & Características \\
\hline 0 & Nenhum edema & Ed $=0 \leq 0,24 \mathrm{~mm}$ \\
\hline 1 & Edema muito leve & Pouco perceptível com Ed $=0,25 \leq$ e $0,49 \mathrm{~mm}$ \\
\hline 2 & Edema leve & $\begin{array}{c}\text { Áreas de bordas bem definidas com aumento } \\
\text { perceptível com Ed }=0,5 \leq 0,74 \mathrm{~mm}\end{array}$ \\
\hline 3 & Edema moderado & Bastante perceptível com $\mathrm{Ed}=0,75 \leq 1 \mathrm{~mm}$ \\
\hline 4 & Edema severo & Extensa área com $\mathrm{Ed} \geq 1 \mathrm{~mm}$ \\
\hline
\end{tabular}

\subsubsection{Morfologia dos dispositivos}

Na microscopia eletrônica de varredura (MEV), um feixe de elétron incide no material e promove a emissão de elétrons secundários, retroespalhados e absorvidos, assim como de raios $X$ característicos (Duarte et al., 2004).

Os dispositivos de hidrogel de PVP foram submetidos à MEV, com o objetivo de verificar a morfologia do material, bem como a distribuição do óleo de açaí nos dispositivos.

As amostras foram liofilizadas e posteriormente fraturadas e acondicionadas em frasco fechado a vácuo até o momento do tratamento para a realização da análise. Antes da visualização, as amostras foram fixadas em um suporte recobertas com ouro. Após, foram fixadas em suporte condutor e observadas em microscópio eletrônico de varredura por emissão de campo, no Centro de Ciências e Tecnologia de Materiais do IPEN.

\subsubsection{Cinética de Liberação}

Os métodos de estudo de liberação desprovidos de membranas limitantes de velocidade são utilizados para comprovar a liberação do fármaco para uma fase simples imiscível, onde é medida a interação fármaco-veículo que afetam as características de liberação (Barry, 2005). 
Os dispositivos de hidrogel de PVP foram cortados em duas partes com pesos próximos, e imersos em $25 \mathrm{~mL}$ de PBS 0,1M pH = 5,0 em frascos de vidro fechados. O ensaio foi realizado em incubadora da Tecnal, modelo TE-420, a $37^{\circ} \mathrm{C}$ sob agitação constante de 120 rpm.

Alíquotas de $200 \mu \mathrm{l}$ da amostra foram coletadas, em duplicata, nos tempos 1, 2, 3, 4, 5, 6 e 24 horas, acondicionadas em eppendorfs e mantidas sob refrigeração até o momento do ensaio de doseamento. A cada coleta o volume foi reposto com PBS 0,1M de $\mathrm{pH}=5,0$.

O doseamento do óleo de açaí foi realizado por meio da quantificação do ácido oleico liberado, em cromatografia a gás acoplado à espectrometria de massas quadrupolo - CG/EM, marca Shimadzu, modelo QP5050.

Para a extração dos ácidos graxos da amostra utilizou-se a extração líquido-líquido com o solvente clorofórmio grau HPLC, o qual foi adicionado às amostras no mesmo volume (1:1). Agitou-se manualmente durante 5 minutos para que houvesse uma maior extração dos ácidos graxos pelo clorofórmio.

Com o auxílio de uma microsseringa graduada introduziram-se $3 \mu \mathrm{L}$ do extrato no injetor do CG. O injetor foi aquecido à temperatura de $250{ }^{\circ} \mathrm{C}$ e dessa forma a amostra foi vaporizada e introduzida na coluna cromatográfica. O injetor foi programado no modo Split $1 / 50$, no qual $50 \%$ da amostra injetada foi transferida para a coluna capilar, resultando numa melhor resolução dos picos do cromatograma. A coluna capilar utilizada foi a Carbowax $20 \mathrm{M}$, cuja fase estacionária é composta de polietilenoglicol. As colunas com polaridade intermediária, como a Carbowax $20 \mathrm{M}$, são as mais indicadas para a análise de ésteres metílicos de ácidos graxos (Martins et al., 2002). O gás de arraste utilizado foi o hélio numa velocidade linear de $32 \mathrm{~cm} / \mathrm{s}$ (medida a $100{ }^{\circ} \mathrm{C}$ ). A programação da coluna realizou-se da seguinte forma: isotermia a $120{ }^{\circ} \mathrm{C}$ por 2 minutos; em seguida a temperatura foi elevada até $250{ }^{\circ} \mathrm{C}$ numa razão de 20 ${ }^{\circ} \mathrm{C} / \mathrm{min}$, totalizando 18,5 minutos de eluição dos analitos por meio da coluna cromatográfica.

Os espectros de massas foram obtidos no modo de ionização por impacto de elétrons com energia de $70 \mathrm{eV}$. A varredura das massas foi realizada no modo Selection Íon Monitoring (SIM), no qual foram selecionados os íons com 
pesos moleculares correspondentes aos do ácido oleico $(69,83,97,111,264$ e 282).

Para quantificar o óleo de açaí liberado foi construída uma curva de calibração com padrão de ácido oleico 99,99\%, da Vetec, utilizando os valores das concentrações conhecidas em relação à área do pico, obtidos no CG/EM. Para a preparação das soluções padrão de ácido oleico, uma quantidade conhecida de ácido oleico foi pesada em balança analítica e adicionou-se clorofórmio, agitando em banho de utrassom por 10 minutos. A partir desta diluição outras foram preparadas atingindo as concentrações de $80 \mu \mathrm{g} / \mathrm{mL}, 128$ $\mu \mathrm{g} / \mathrm{mL}, 160 \mu \mathrm{g} / \mathrm{mL}$ e $192 \mu \mathrm{g} / \mathrm{mL}$ de ácido oleico em clorofórmio.

Pela curva de calibração foi obtida a equação da reta (Equação 6), utilizada para calcular a concentração de ácido oleico liberado.

$$
\begin{aligned}
& \mathrm{C}_{\text {oleico }}=4589,7 \text { (área do pico) }-42367 \\
& \mathrm{R}^{2}=0,9993
\end{aligned}
$$

Sendo:

$\left(\mathrm{C}_{\text {oleico }}\right)=$ Concentração de ácido oleico em $\mu \mathrm{g} / \mathrm{mL}$.

Área do pico = área do pico obtida pela análise em CG/EM 


\section{RESULTADOS E DISCUSSÃO}

\subsection{Determinação do efeito da radiação no óleo de açaí}

O cromatograma obtido pela análise do óleo de açaí não irradiado apresenta-se na FIG. 17. Os principais constituintes detectados foram os ácidos graxos saturados: palmítico, mirístico e láurico e os insaturados: oleico e linoleico.

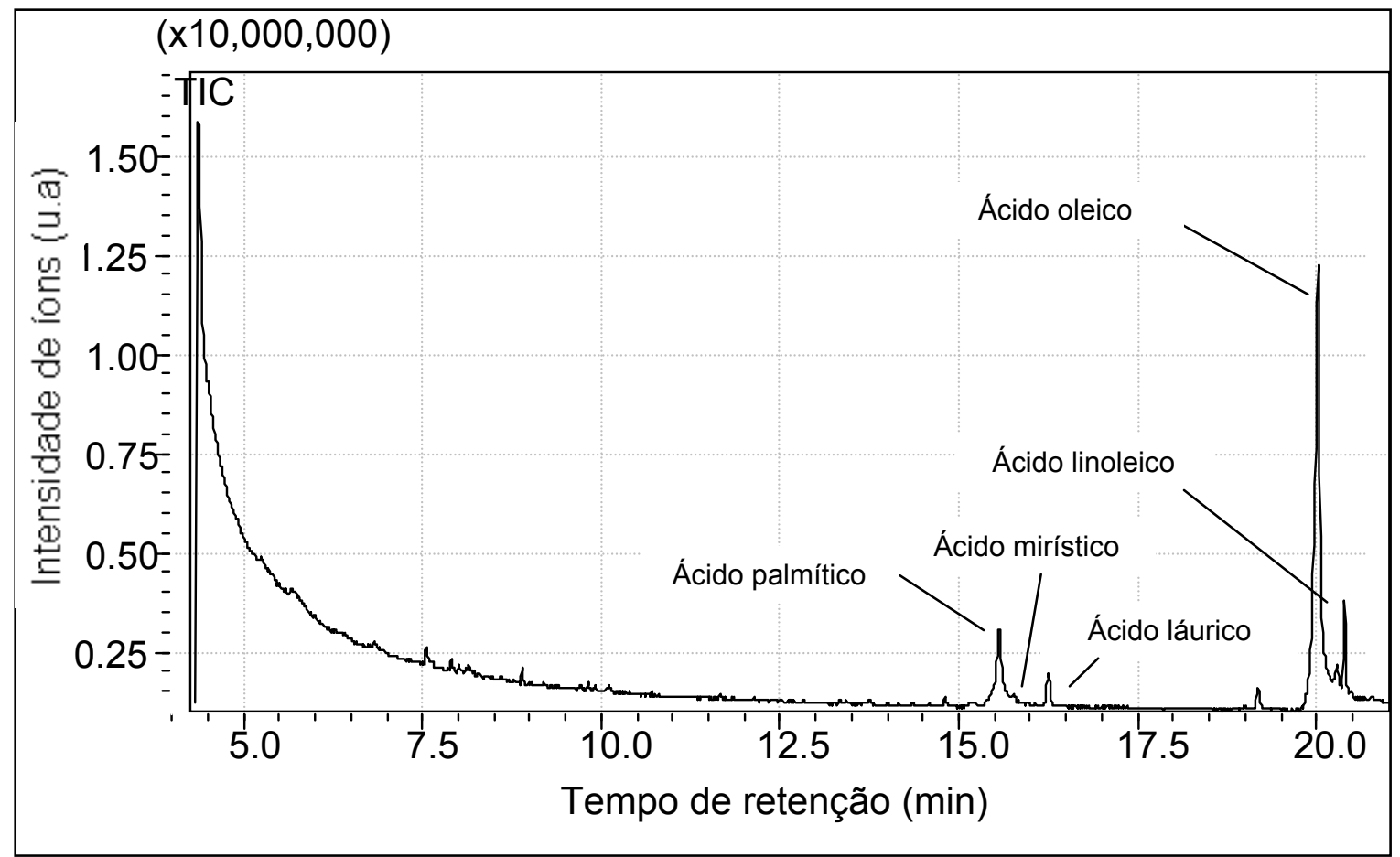

FIGURA 17 - Cromatograma do óleo de açaí não irradiado

Já o cromatograma obtido pela análise do óleo de açaí irradiado está representado na FIG. 18. Pode-se observar a detecção dos mesmos ácidos graxos, entretanto, foi observada também a presença do dibutil ftalato (ácido 1,2benzenodicarboxílico dibutil éster), não existente na amostra não irradiada. Como a irradiação foi realizada em frascos de PVC, pode-se concluir que o dibutil ftalato foi lixiviado do tubo para o óleo sob efeito da radiação. 


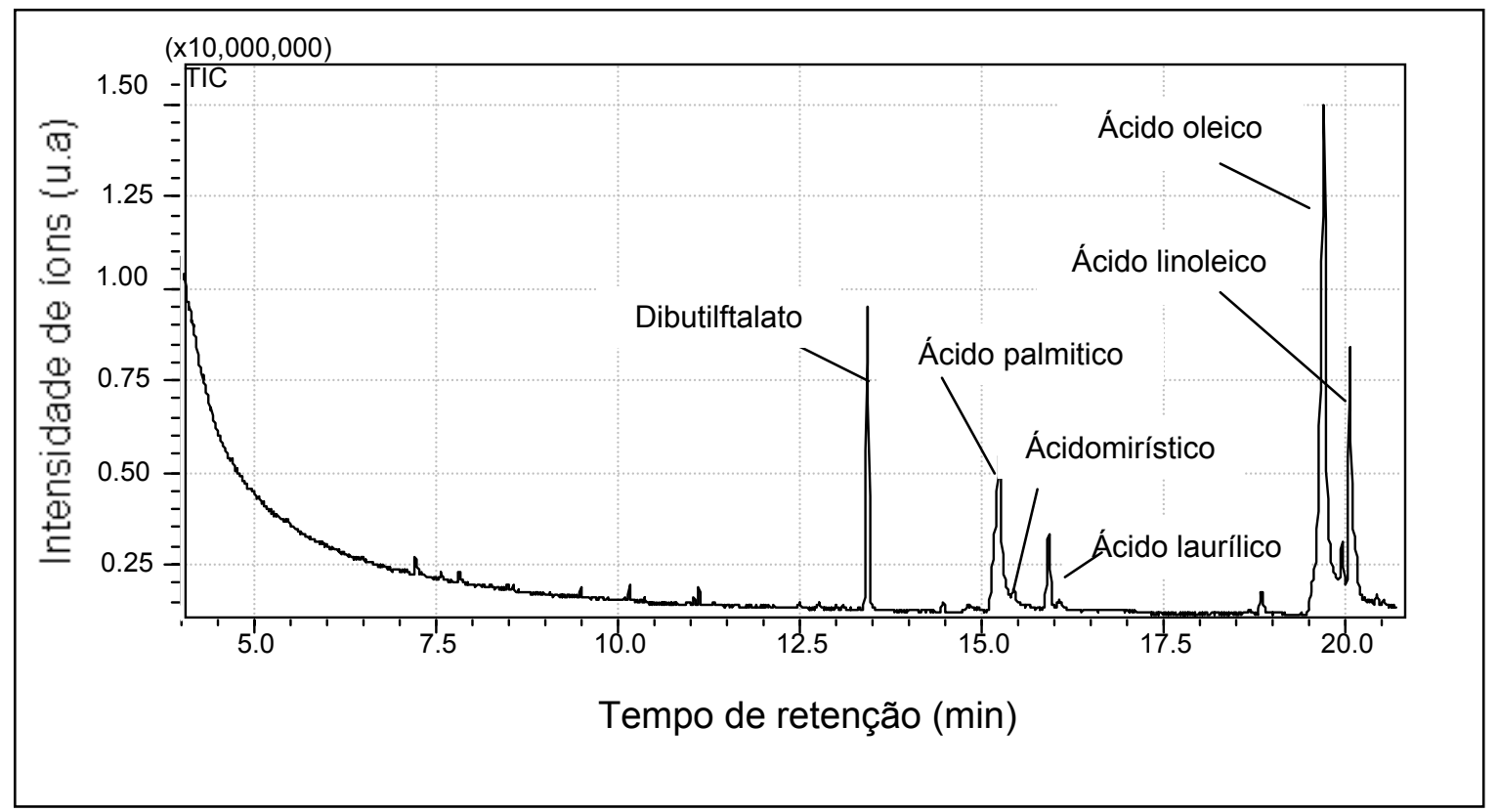

FIGURA 18 - Cromatograma do óleo de açaí irradiado a 25 kGy

Uma análise semiquantitativa das concentrações dos vários ácidos graxos foi realizada e está representada nas tabelas 10 e 11. Na TAB. 10 são apresentados os resultados referentes ao óleo de açaí não irradiado, enquanto que na TAB. 11 os resultados do óleo de açaí irradiado. Em ambas o composto mais abundante, ou seja, o ácido oleico foi estabelecido como padrão interno igual a 100. Observou-se a diminuição de concentração dos monoésteres provavelmente pela transformação do grupo éster em ácido carboxílico quando submetido à radiação gama. 
TABELA 10 - Análise semiquantitativa dos ácidos graxos do óleo de açaí via CG/EM da amostra sem irradiar.

\begin{tabular}{ccccccc}
\hline TR (min) & $\begin{array}{c}\text { Composto } \\
\text { (INCI Name) }\end{array}$ & $\begin{array}{c}\text { Fórmula } \\
\text { Molecular }\end{array}$ & PM & Área (TIC) & IR(\%) & CAS \\
\hline 15,2 & Ácido palmitico & $\mathrm{C}_{16} \mathrm{H}_{32} \mathrm{O}_{2}$ & 256 & 10037612 & 32,2 & $57-10-3$ \\
15,4 & Ácido miristico & $\mathrm{C}_{14} \mathrm{H}_{28} \mathrm{O}_{2}$ & 228 & 1204918 & 3,9 & $544-63-8$ \\
15,9 & Palmitato de etila & $\mathrm{C}_{18} \mathrm{H}_{36} \mathrm{O}_{2}$ & 284 & 4063860 & 13,1 & $628-97-7$ \\
18,8 & Oleato de metila & $\mathrm{C}_{19} \mathrm{H}_{36} \mathrm{O}_{2}$ & 296 & 2482392 & 8,0 & $112-62-9$ \\
19,7 & Ácido oleico & $\mathrm{C}_{18} \mathrm{H}_{38} \mathrm{O}_{2}$ & 282 & 31131622 & 100,0 & $112-80-1$ \\
19,9 & Cloreto de linoleoíla & $\mathrm{C}_{18} \mathrm{H}_{31} \mathrm{ClO}_{2}$ & 298 & 3070993 & 9,9 & $7459-33-8$ \\
20,0 & Oleato de etila & $\mathrm{C}_{18} \mathrm{H}_{38} \mathrm{O}_{2}$ & 310 & 8445239 & 27,1 & $111-62-6$ \\
\hline
\end{tabular}

TABELA 11 - Análise semiquantitativa dos ácidos graxos do óleo de açaí via CG/EM da amostra irradiada.

\begin{tabular}{ccccccc}
\hline TR (min) & $\begin{array}{c}\text { Composto } \\
\text { (INCI Name) }\end{array}$ & $\begin{array}{c}\text { Fórmula } \\
\text { Molecular }\end{array}$ & PM & Área (TIC) & IR(\%) & CAS \\
\hline \hline 15,2 & Ácido palmitico & $\mathrm{C}_{16} \mathrm{H}_{32} \mathrm{O}_{2}$ & 256 & 31284651 & 37,3 & $57-10-3$ \\
15,4 & Ácido miristico & $\mathrm{C}_{14} \mathrm{H}_{28} \mathrm{O}_{2}$ & 228 & 4381154 & 5,2 & $544-63-8$ \\
15,9 & Palmitato de etila & $\mathrm{C}_{18} \mathrm{H}_{36} \mathrm{O}_{2}$ & 284 & 9179540 & 11,0 & $628-97-7$ \\
18,8 & Oleato de metila & $\mathrm{C}_{19} \mathrm{H}_{36} \mathrm{O}_{2}$ & 296 & 2775850 & 3,3 & $112-62-9$ \\
19,7 & Ácido oleico & $\mathrm{C}_{18} \mathrm{H}_{38} \mathrm{O}_{2}$ & 282 & 83760841 & 100,0 & $112-80-1$ \\
19,9 & Cloreto de linoleoíla & $\mathrm{C}_{18} \mathrm{H}_{31} \mathrm{ClO}_{10}$ & 298 & 7293915 & 8,7 & $7459-33-8$ \\
20,0 & Oleato de etila & $\mathrm{C}_{18} \mathrm{H}_{38} \mathrm{O}_{2}$ & 310 & 32207517 & 38,5 & $111-62-6$ \\
\hline
\end{tabular}

Legenda: TR $(\min )=$ tempo de retenção em minutos; $P M=$ peso molecular do composto analisado; $I R=$ intensidade relativa; $C A S=$ número do Chemical American Standard.

Mediante os resultados apresentados acima, observou-se que não houve o surgimento ou o desaparecimento de alguma molécula nova como consequência da irradiação. Observou-se apenas algum consumo de ésteres e eventual conversão em ácidos carboxílicos. Há também uma pequena diminuição do composto clorado presente, conforme esperado. 
Após a irradiação foi possível verificar uma maior área dos ácidos graxos presentes no óleo de açaí, o que demonstra que os compostos polares foram consumidos, ou que não são mais sensíveis a coluna utilizada, evidenciando os compostos apolares. Os polifenóis e os tocoferóis presentes no óleo de açaí, conhecidos como potentes antioxidantes, também podem ter colaborado para que não houvesse degradação dos ácidos graxos frente à radiação. Portanto, pode-se concluir que o óleo de açaí na ausência de umidade mostrou-se bastante resistente à radiação gama.

Toledo e colaboradores (2007) realizaram um estudo com soja irradiada nas doses de 2,5, 5 e 10 kGy, e não encontraram alterações na sua composição lipídica, o que reforça os dados encontrados neste estudo.

Uma análise quantitativa do óleo de açaí também foi realizada no CG/EM, na qual foi comparada a área de pico do óleo analisado com os dados existentes na biblioteca NIST. Obteve-se assim uma análise quantitativa dos ácidos graxos, conforme observado na FIG. 19 e TAB. 12.

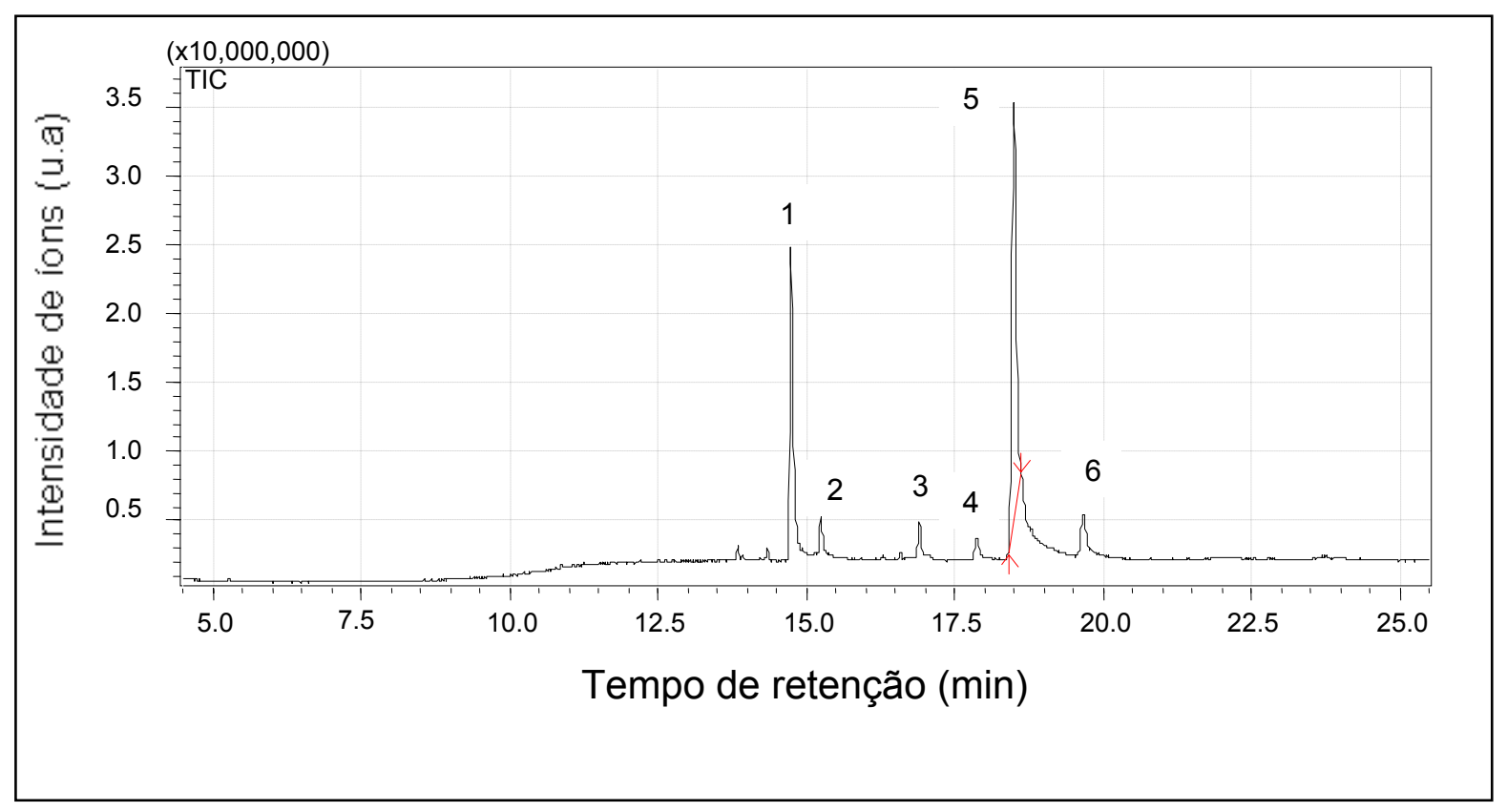

FIGURA 19 - Cromatograma do óleo de açaí para análise quantitativa dos ácidos graxos 
TABELA 12 - Análise quantitativa dos ácidos graxos do óleo de açaí

\begin{tabular}{ccccccc}
\hline Número & TR $(\mathbf{m i n})$ & $\begin{array}{c}\text { Composto } \\
\text { (INCI Name) }\end{array}$ & $\begin{array}{c}\text { Fórmula } \\
\text { Molecular }\end{array}$ & PM & CAS & $\begin{array}{c}\text { Quantidade } \\
\text { (\%) }\end{array}$ \\
\hline \hline 1 & 14,747 & $\begin{array}{c}\text { Ácido Palmítico } \\
\text { ( }{ }_{16} \mathrm{H}_{32} \mathrm{O}_{2}\end{array}$ & 256 & $57-10-3$ & 35,11 \\
2 & 15,249 & $\begin{array}{c}\text { Ácido } \\
\text { Undecilênico }\end{array}$ & $\mathrm{C}_{11} \mathrm{H}_{20} \mathrm{O}_{2}$ & 184 & $1333-28-4$ & 4,41 \\
3 & 16,916 & $\begin{array}{c}13-O c t a d e n a)^{*} \\
4\end{array}$ & $\mathrm{C}_{18} \mathrm{H}_{34} \mathrm{O}$ & 266 & $58594-45-9$ & 3,80 \\
5 & 17,885 & Ácido Esteárico & $\mathrm{C}_{18} \mathrm{H}_{36} \mathrm{O}_{2}$ & 284 & $57-11-4$ & 1,89 \\
6 & 18,509 & Ácido Oleico & $\mathrm{C}_{18} \mathrm{H}_{38} \mathrm{O}_{2}$ & 282 & $112-80-1$ & 50,54 \\
\hline
\end{tabular}

Legenda: TR $(\min )=$ tempo de retenção em minutos; PM = peso molecular do composto analisado; CAS = número do Chemical American Standard; ${ }^{*}=$ aldeído.

Essa análise teve como objetivo quantificar o ácido oleico presente no óleo de açaí. Com base na TAB. 12, foi considerado que o óleo de açaí possui $50,54 \%$ de ácido oleico.

O ensaio de comportamento do óleo de açaí mediante a radiação objetivou analisar apenas os ácidos graxos presentes, principalmente o ácido oleico, que será quantificado no ensaio de cinética de liberação. 0 comportamento dos demais componentes, como as antocianinas, vitaminas e minerais não foi verificada. Esses componentes são de fundamental importância no processo de regeneração da pele, principalmente o efeito antirradicais livres das antocianinas, que pode ser afetado pela ação da radiação.

\subsection{Matrizes Poliméricas}

\subsubsection{Obtenção das matrizes poliméricas}

As matrizes de hidrogel de PVP foram obtidas por meio da radiação ionizante e submetidas à avaliação visual, para serem consideradas adequadas. Em seguida foram caracterizadas por testes de fração gel, intumescimento, propriedades mecânicas e citotoxicidade. 
Os critérios utilizados na avaliação das matrizes foram formação de filme homogêneo, transparência, elasticidade, flexibilidade e resistência adequada para manipulação, nos quais ambas se mostraram adequadas (FIG. 20 e 21). A matriz B apresentou-se mais transparente do que a matriz A por não conter o ágar, e também mais elástica, devido à presença da glicerina.

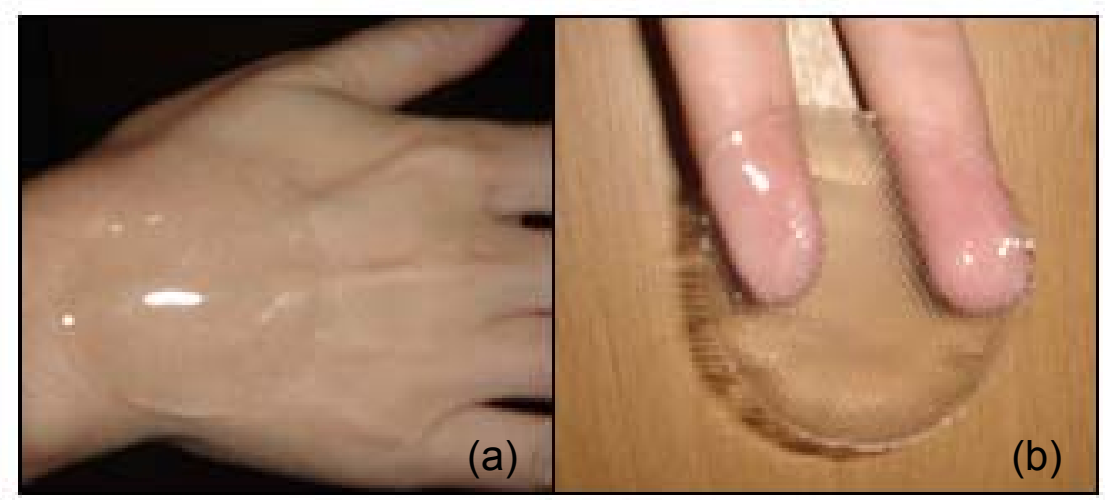

FIGURA 20 - Matriz de hidrogel de PVP - A: (a) transparência; (b) elasticidade

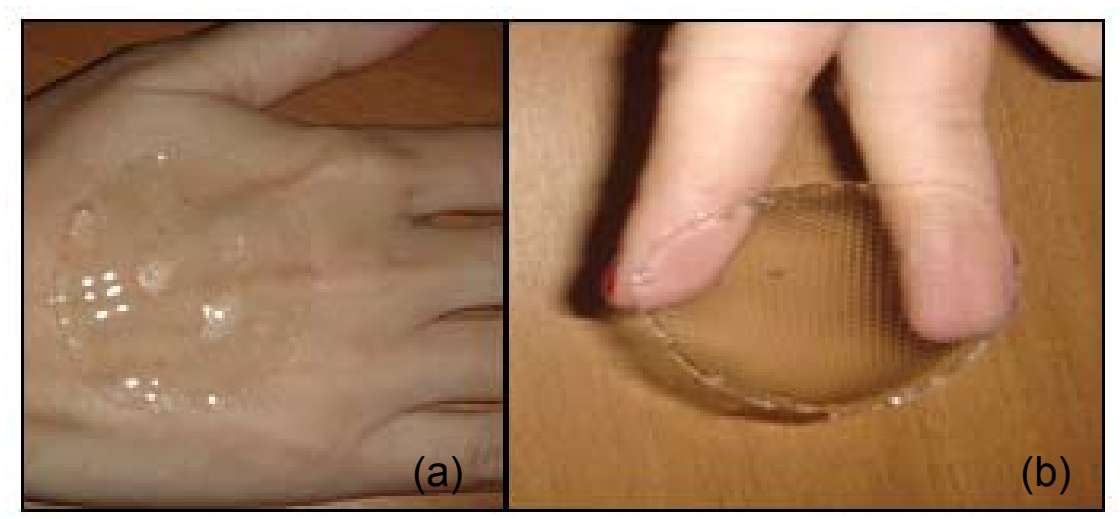

FIGURA 21 - Matriz de hidrogel de PVP - B: (a) transparência; (b) elasticidade

\subsubsection{Fração gel}

O ensaio de fração gel permite avaliar a fração de polímero que sofreu reticulação, ou seja, a quantidade do polímero que se ligou formando uma rede polimérica. 
Substâncias com capacidade plastificante e do grupo álcool, como o PEG e o glicerina, diminuem a capacidade de reticulação dos hidrogéis (Ajji et al., 2005).

Conforme pode ser observado na TAB. 13, as duas matrizes poliméricas apresentaram resultados próximos, cerca de $66 \%$, quando submetidas à radiação na dose de $15 \mathrm{kGy}$. Considerado um bom resultado tendo em vista a dose total de radiação e a concentração de agentes plastificantes e scavengers, como o PEG e a glicerina, presentes nas duas matrizes.

Apesar de a matriz A conter uma quantidade de PVP menor do que a da matriz $\mathbf{B}$, os resultados foram próximos devido ao ágar que auxilia no processo de reticulação, enquanto a glicerina dificulta esse processo.

Estudos realizados por Ajji e colaboradores (2005) com hidrogéis de PVP na concentração de $6 \%$, irradiados a $25 \mathrm{kGy}$, obtiveram um resultado de $81 \%$ de fração gel.

TABELA 13 - Resultados de fração gel das matrizes de hidrogel de PVP

\begin{tabular}{cccc}
\hline Matriz & $\mathbf{m i}(\mathbf{g})$ & $\mathbf{m f}(\mathbf{g})$ & Fração Gel (\%) \\
\hline \multirow{3}{*}{ A } & 0,05 & 0,03 & \\
& 0,05 & 0,03 & $67,02 \pm 0,56$ \\
& 0,05 & 0,04 & \\
\hline \multirow{2}{*}{ B } & 0,27 & 0,18 & \\
& 0,24 & 0,15 & $65,78 \pm 0,85$ \\
& 0,24 & 0,16 & \\
\hline
\end{tabular}

\subsubsection{Intumescimento}

Os resultados de intumescimento das matrizes de PVP estão apresentados na TAB. 14 e FIG. 22. Observa-se que a matriz $\mathbf{A}$ obteve um grau de intumescimento muito maior que a matriz $\mathbf{B}$ nas 6 primeiras horas, devido à presença da glicerina na matriz $\mathbf{B}$, que dificulta o desemaranhamento da rede tridimensional. No tempo $24 \mathrm{~h}$, a matriz B apresentou um grau de intumescimento de aproximadamente $42 \%$ a mais do que a matriz A, pela glicerina já ter se soltado da rede, permitindo o intumescimento do polímero. Essa significativa 
diferença deve ser considerada na eventual utilização dessas matrizes na incorporação de princípios ativos.

Após 24 horas a matriz $\mathbf{A}$ atingiu um equilíbrio, com valor de intumescimento próximo a 1700\%, para uma dose de irradiação de 15 kGy. Este valor ficou muito próximo a um estudo realizado com hidrogéis de PVP a 6\%, irradiados a $25 \mathrm{kGy}$, que apresentaram um grau de intumescimento em torno de 1800\% após 24 horas de ensaio (Ajji et al., 2005). Já na matriz B não conseguimos observar esse equilíbrio.

TABELA 14 - Resultados de intumescimento das matrizes de hidrogel de PVP

\begin{tabular}{ccc}
\hline $\begin{array}{c}\text { Tempo } \\
\text { (h) }\end{array}$ & A & B \\
\hline 1 & $984,09 \pm 14,24$ & $499,64 \pm 28,41$ \\
2 & $1394,69 \pm 6,41$ & $877,50 \pm 33,17$ \\
3 & $1612,56 \pm 5,04$ & $1187,35 \pm 26,80$ \\
4 & $1661,61 \pm 3,56$ & $1373,13 \pm 23,96$ \\
5 & $1698,99 \pm 2,26$ & $1560,23 \pm 20,52$ \\
6 & $1734,42 \pm 0,79$ & $1668,80 \pm 18,77$ \\
24 & $1760,91 \pm 1,30$ & $2501,94 \pm 7,82$ \\
\hline
\end{tabular}

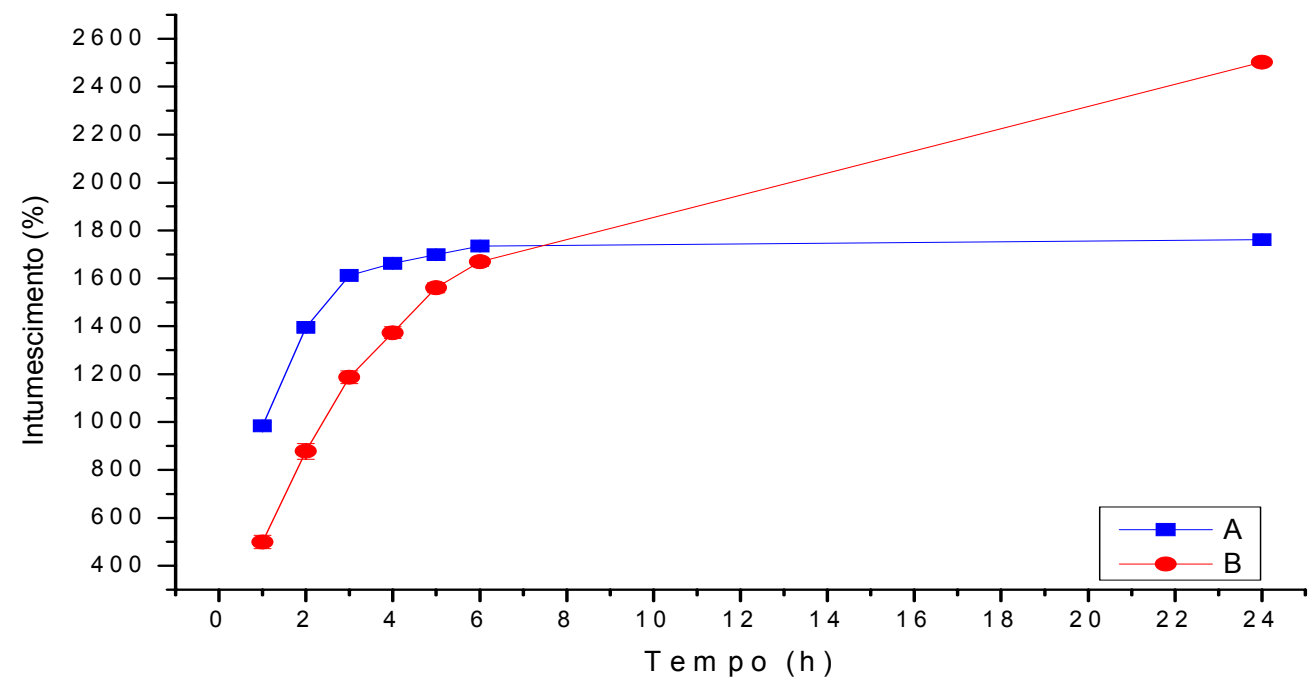

FIGURA 22 - Curvas de intumescimento das matrizes de hidrogel de PVP 
Ao analisarmos o processo de obtenção das matrizes, verificamos que a matriz A já havia sofrido um intumescimento de cerca de $1150 \%$ (6\% de polímero para $92 \%$ de solventes), e a matriz B de 300\% (25\% de polímero para $75 \%$ de solventes). Assim, obtemos um resultado final de intumescimento de $2910,91 \%$ para a matriz $\mathbf{A}$ e de $2801,94 \%$ para a matriz $\mathbf{B}$. Os resultados são próximos, da mesma maneira que os apresentados no ensaio de fração gel.

\subsubsection{Propriedades mecânicas}

Os resultados de força máxima de perfuração e deformação das matrizes são mostrados nas TAB. 15 e 16 e FIG. 23 e 24.

TABELA 15 - Força máxima de perfuração e deformação das matrizes A obtidas no ensaio de perfuração

\begin{tabular}{ccccc}
\hline Amostra & Força (N) & $\begin{array}{c}\text { Deslocamento } \\
\text { probe }(\mathbf{m m})\end{array}$ & $\mathbf{\Delta l}$ & $\begin{array}{c}\text { Deformação } \\
\mathbf{( \% )}\end{array}$ \\
\hline 1 & 0,56 & 18,606 & 8,899 & 59,330 \\
2 & 0,37 & 16,522 & 7,315 & 48,769 \\
3 & 0,49 & 20,152 & 10,122 & 67,478 \\
\hline Média & $0,47 \pm 0,10$ & $18,427 \pm 1,822$ & $8,779 \pm 1,407$ & $58,526 \pm 9,380$ \\
\hline
\end{tabular}




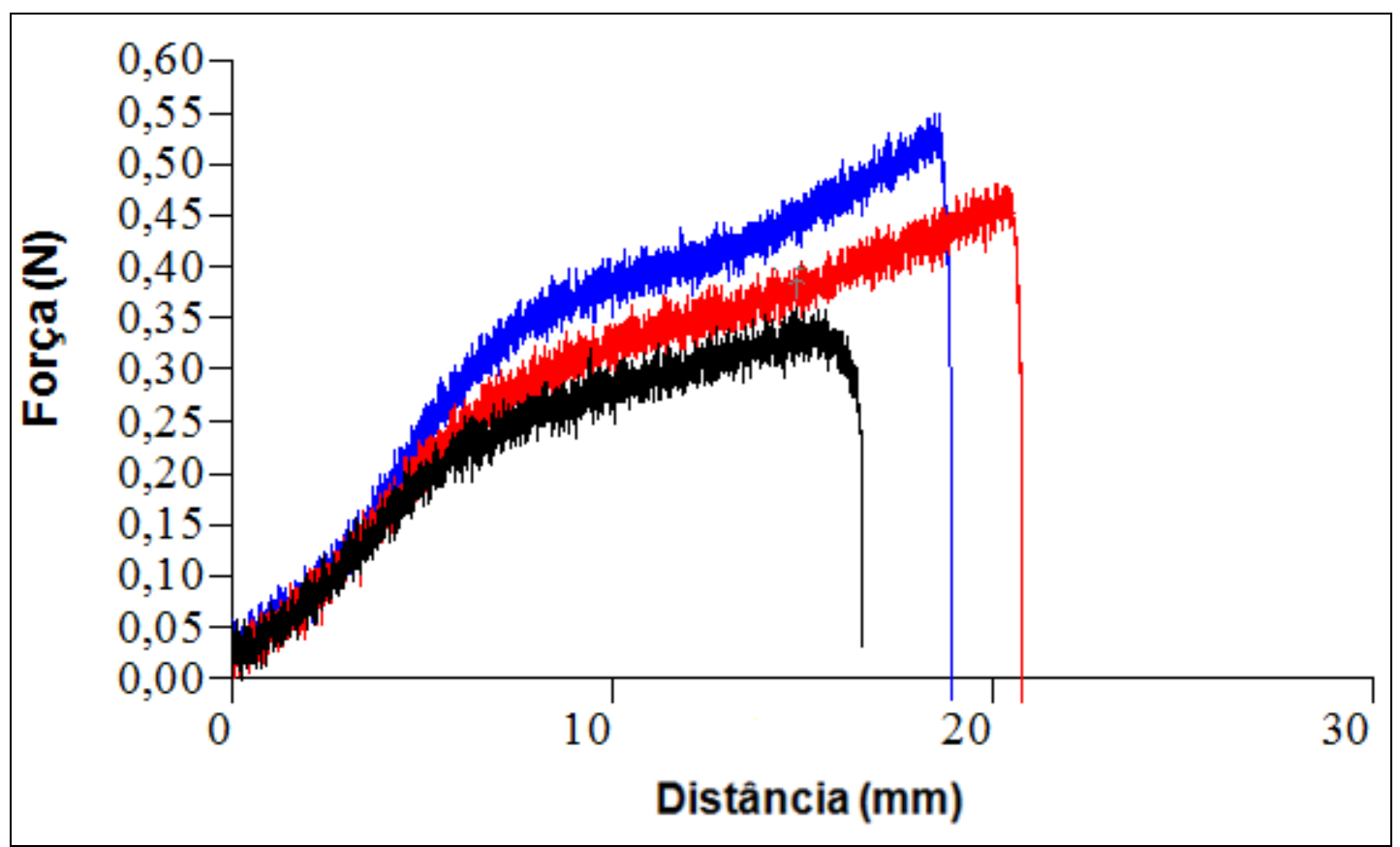

FIGURA 23 - Curva de força aplicada à matriz A para perfuração em função da distância percorrida pelo probe até a perfuração da mesma

TABELA 16 - Força máxima de perfuração e deformação das matrizes $B$ obtidas no ensaio de perfuração

\begin{tabular}{ccccc}
\hline Amostra & Força (N) & $\begin{array}{c}\text { Deslocamento } \\
\text { probe }(\mathbf{m m})\end{array}$ & $\boldsymbol{\Delta l}$ & Deformação (\%) \\
\hline \hline 1 & 0,37 & 39,803 & 24,803 & 165,35 \\
2 & 0,31 & 37,085 & 22,085 & 147,23 \\
3 & 0,44 & 50,584 & 35,584 & 237,23 \\
\hline Média & $0,37 \pm 0,07$ & $42,491 \pm 7,140$ & $27,491 \pm 7,140$ & $183,271 \pm 47,597$ \\
\hline
\end{tabular}




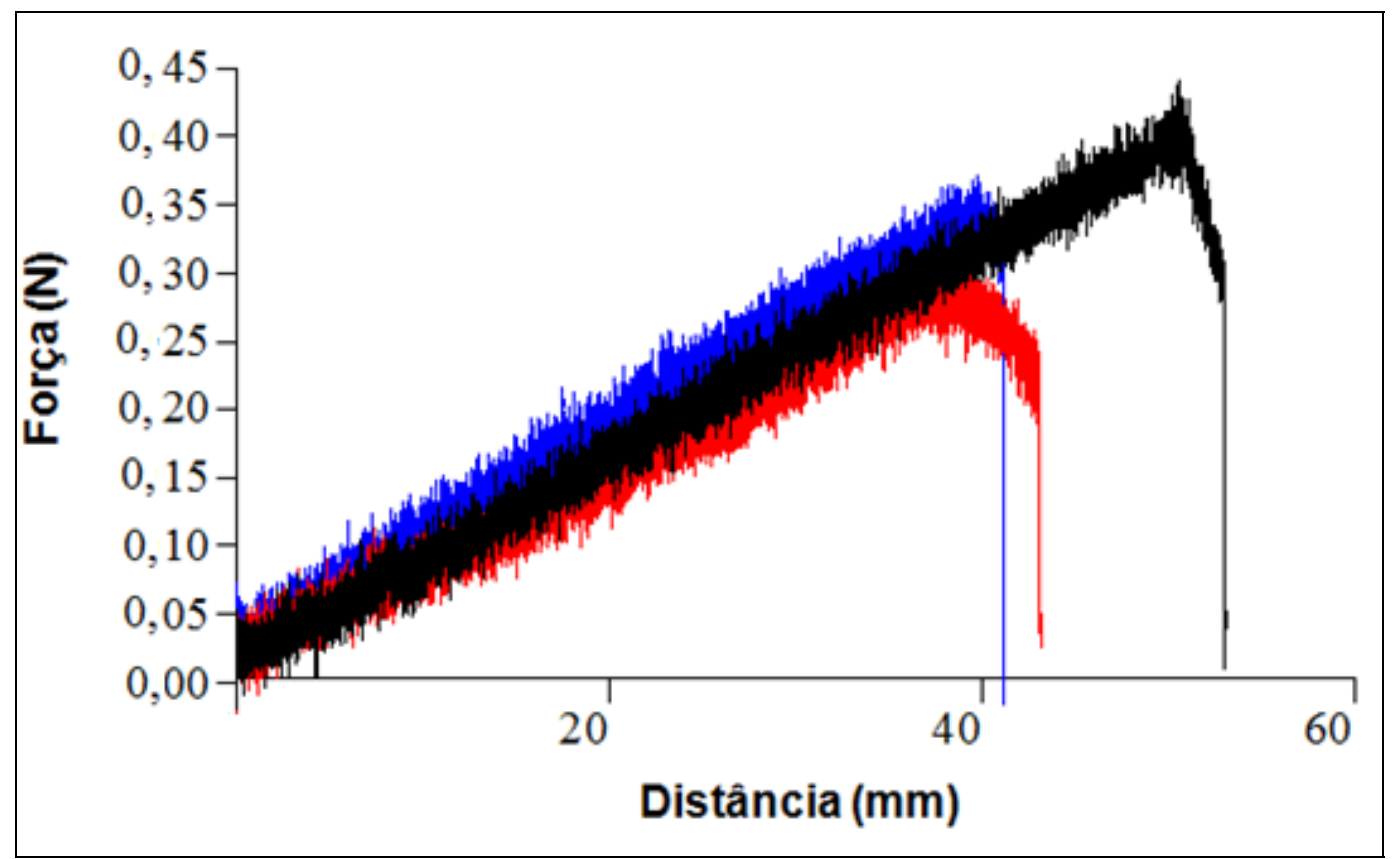

FIGURA 24 - Curva de força aplicada à matriz B para perfuração em função da distância percorrida pelo probe até a perfuração da mesma

Pode-se observar por meio do perfil da curva de força para perfuração em função da distância percorrida que a matriz $\mathbf{B}$ possui uma maior resistência à perfuração, ou seja, é mais elástica. A inclinação da curva e a força aplicada mostram que a matriz $\mathbf{A}$ é mais rígida, e que sua deformação permanente ocorre logo no início do percurso percorrido.

\subsubsection{Citotoxicidade}

Com a média da densidade óptica de cada diluição do extrato foi calculada a porcentagem de viabilidade celular pela divisão da média da densidade óptica de cada diluição pela média da porcentagem de viabilidade celular do controle de células, multiplicado por 100 (TAB. 17).

Gráficos da porcentagem de viabilidade celular em função da concentração dos extratos foram traçados e pela curva de viabilidade celular obtida foi possível verificar o índice de citotoxicidade $\mathrm{IC}_{50 \%}$, que indica a concentração do extrato que provoca lise ou morte de $50 \%$ das células. Todas as amostras que apresentarem curvas de viabilidade celular acima da linha do $\mathrm{IC}_{50 \%}$ são consideradas não tóxicas e aquelas que cruzarem ou estiverem abaixo da 
linha $\mathrm{IC}_{50 \%}$ são consideradas tóxicas e o $\mathrm{IC}_{50 \%}$ é obtido na intersecção da curva de viabilidade celular com a linha do $\mathrm{IC}_{50 \%}$.

As matrizes de hidrogel de PVP analisadas mostraram comportamento semelhante ao do controle negativo, apresentando as curvas de viabilidade celular acima da linha do $\mathrm{IC}_{50 \%}$, ou seja, apresentaram comportamento não citotóxico. Quanto ao controle positivo, foi observado que a curva de viabilidade celular cruzou a linha do $\mathrm{IC}_{50 \%}$, e na intersecção pode ser obtido o valor do índice de citotoxicidade de $31 \%$. Os controles são utilizados para confirmar o desempenho do teste e a toxicidade do material. As curvas de viabilidade celular das matrizes de hidrogel de PVP estão apresentadas na FIG. 25.

TABELA 17 - Resultados de viabilidade celular das matrizes de hidrogel de PVP

\begin{tabular}{ccccc}
\hline $\begin{array}{c}\text { Concentração } \\
\text { do extrato (\%) }\end{array}$ & $\begin{array}{c}\text { Controle } \\
\text { Positivo }\end{array}$ & $\begin{array}{c}\text { Controle } \\
\text { Negativo }\end{array}$ & A & B \\
\hline 100 & $0 \pm 0$ & $89 \pm 13$ & $131 \pm 10$ & $109 \pm 11$ \\
50 & $18 \pm 14$ & $98 \pm 6$ & $103 \pm 4$ & $93 \pm 4$ \\
25 & $60 \pm 6$ & $90 \pm 10$ & $99 \pm 18$ & $79 \pm 8$ \\
12,5 & $74 \pm 6$ & $99 \pm 13$ & $86 \pm 18$ & $84 \pm 11$ \\
6,25 & $79 \pm 19$ & $93 \pm 9$ & $92 \pm 14$ & $78 \pm 3$ \\
\hline
\end{tabular}




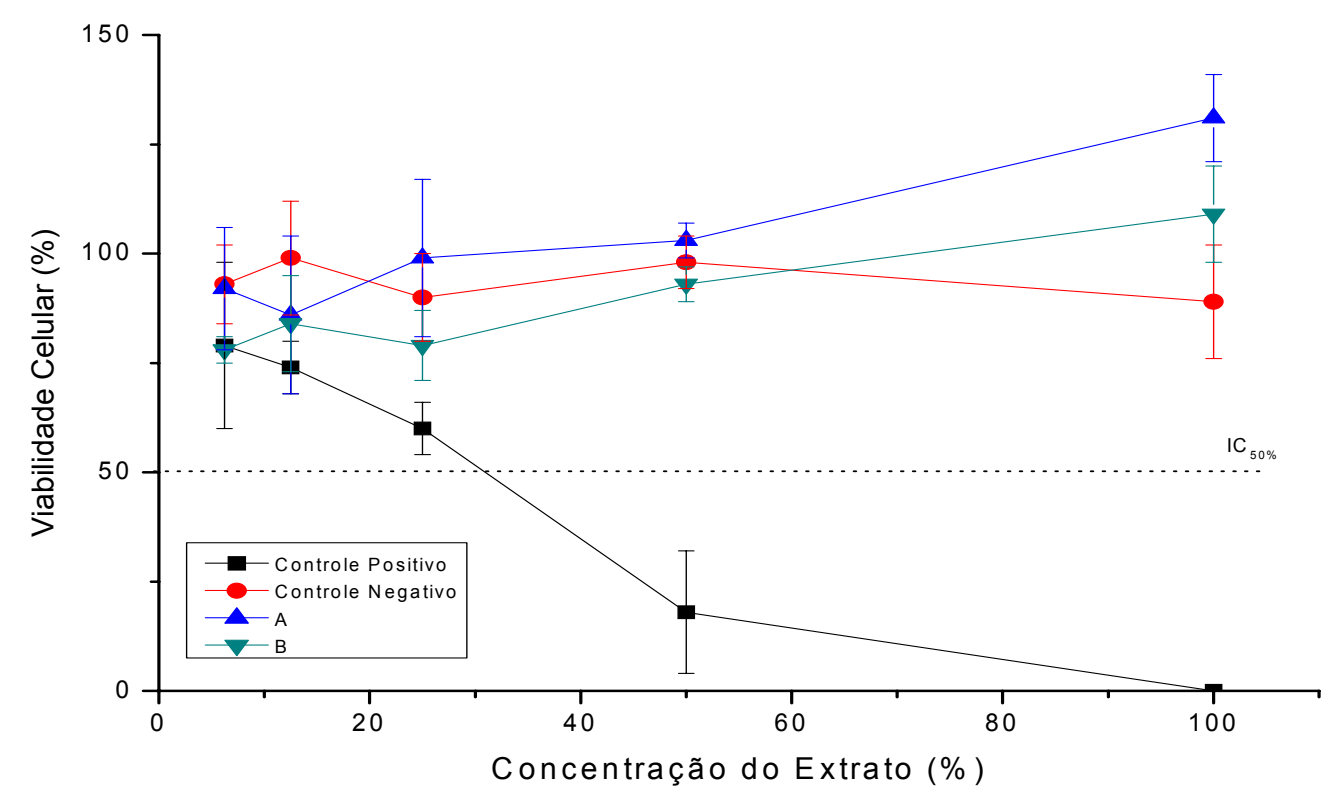

FIGURA 25 - Curvas de viabilidade celular das matrizes de hidrogel de PVP

\subsection{Dispositivo}

\subsubsection{Obtenção dos dispositivos}

Os dispositivos de hidrogel de PVP foram avaliados visualmente quanto a sua homogeneidade, elasticidade e resistência a manipulação (FIG. 26 e 27), os quais apresentaram-se adequados para serem submetidos aos ensaios de caracterização e cinética de liberação.

Devido à presença do óleo de açaí, os dois dispositivos apresentaramse opacos e o dispositivo A1 esbranquiçado, provavelmente devido à adição do emulsionante. 


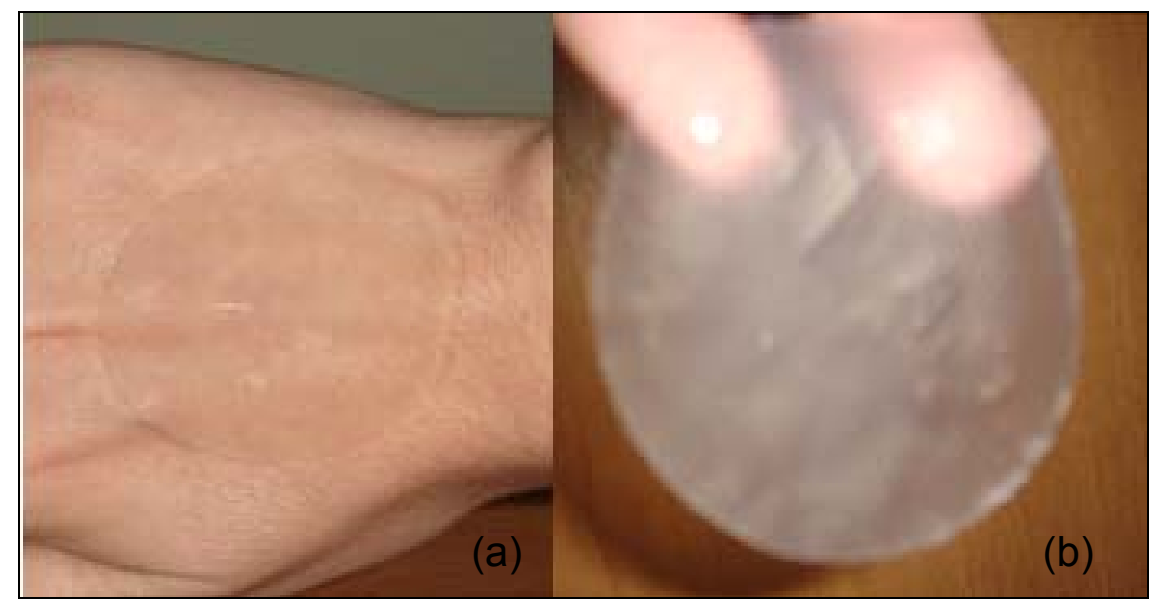

FIGURA 26 - Dispositivo de hidrogel de PVP - A1: (a) homogeneidade; (b) elasticidade

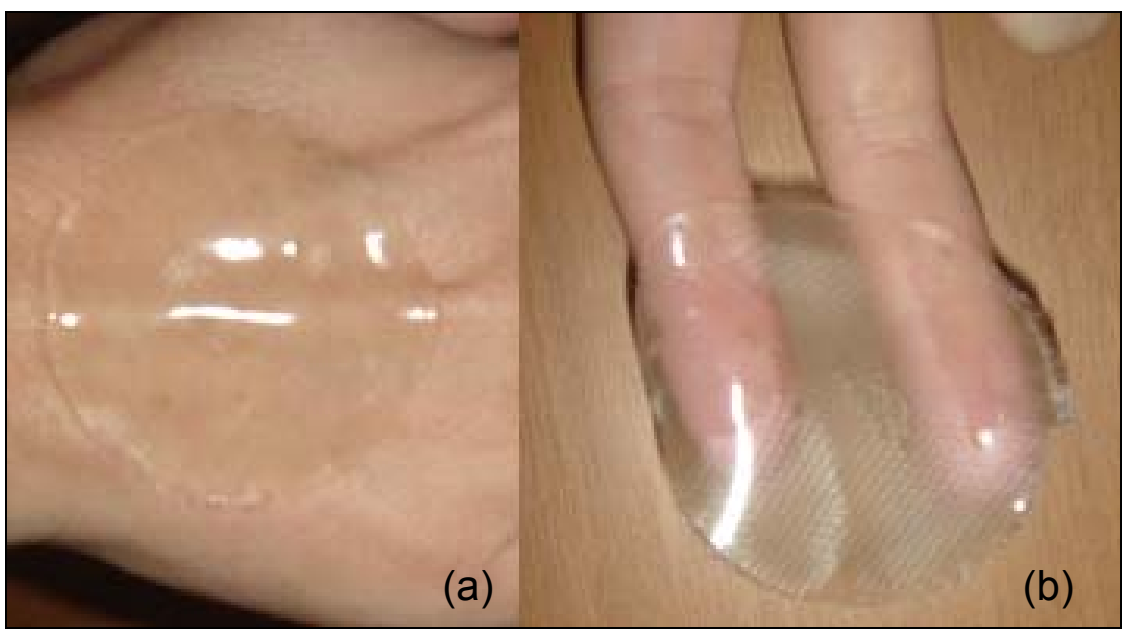

FIGURA 27 - Dispositivo de hidrogel de PVP - B1: (a) homogeneidade; (b) elasticidade

\subsubsection{Fração gel}

Os resultados de fração gel para os dispositivos de hidrogel de PVP apresentaram uma menor percentagem no dispositivo A1, como observado na TAB. 18, provavelmente devido à adição do agente emulsionante. 
TABELA 18 - Resultados de fração gel dos dispositivos de hidrogel de PVP

\begin{tabular}{cccc}
\hline Dispositivo & mi (g) & mf (g) & Fração Gel (\%) \\
\hline \multirow{2}{*}{ A1 } & 0,11 & 0,06 & \\
& 0,11 & 0,06 & $55,30 \pm 1,29$ \\
& 0,14 & 0,08 & \\
\hline \multirow{2}{*}{ B1 } & 0,25 & 0,16 & \\
& 0,25 & 0,16 & $63,06 \pm 0,78$ \\
& 0,25 & 0,16 & \\
\hline
\end{tabular}

\subsubsection{Intumescimento}

Os resultados de intumescimento dos dispositivos de hidrogel de PVP apresentaram um leve decaimento quando comparados ao das suas matrizes, conforme observado na TAB. 19 e FIG. 28.

Com a adição do óleo de açaí, aumentou o grupo hidrofóbico, retardando ainda mais o intumescimento dos dispositivos.

TABELA 19 - Resultados de intumescimento dos dispositivos de hidrogel de PVP

\begin{tabular}{ccc}
\hline \multirow{2}{*}{ Tempo (h) } & \multicolumn{2}{c}{ Intumescimento (\%) } \\
& A1 & B1 \\
\hline 1 & $627,72 \pm 8,43$ & $386,40 \pm 9,18$ \\
2 & $963,56 \pm 5,11$ & $727,37 \pm 11,36$ \\
4 & $1139,59 \pm 6,52$ & $962,16 \pm 9,76$ \\
5 & $1289,05 \pm 6,09$ & $1181,75 \pm 8,67$ \\
6 & $1354,06 \pm 8,73$ & $1356,26 \pm 9,16$ \\
24 & $1455,01 \pm 1,04$ & $1528,72 \pm 5,54$ \\
& $1523,79 \pm 12,53$ & $2746,68 \pm 3,00$ \\
\hline
\end{tabular}




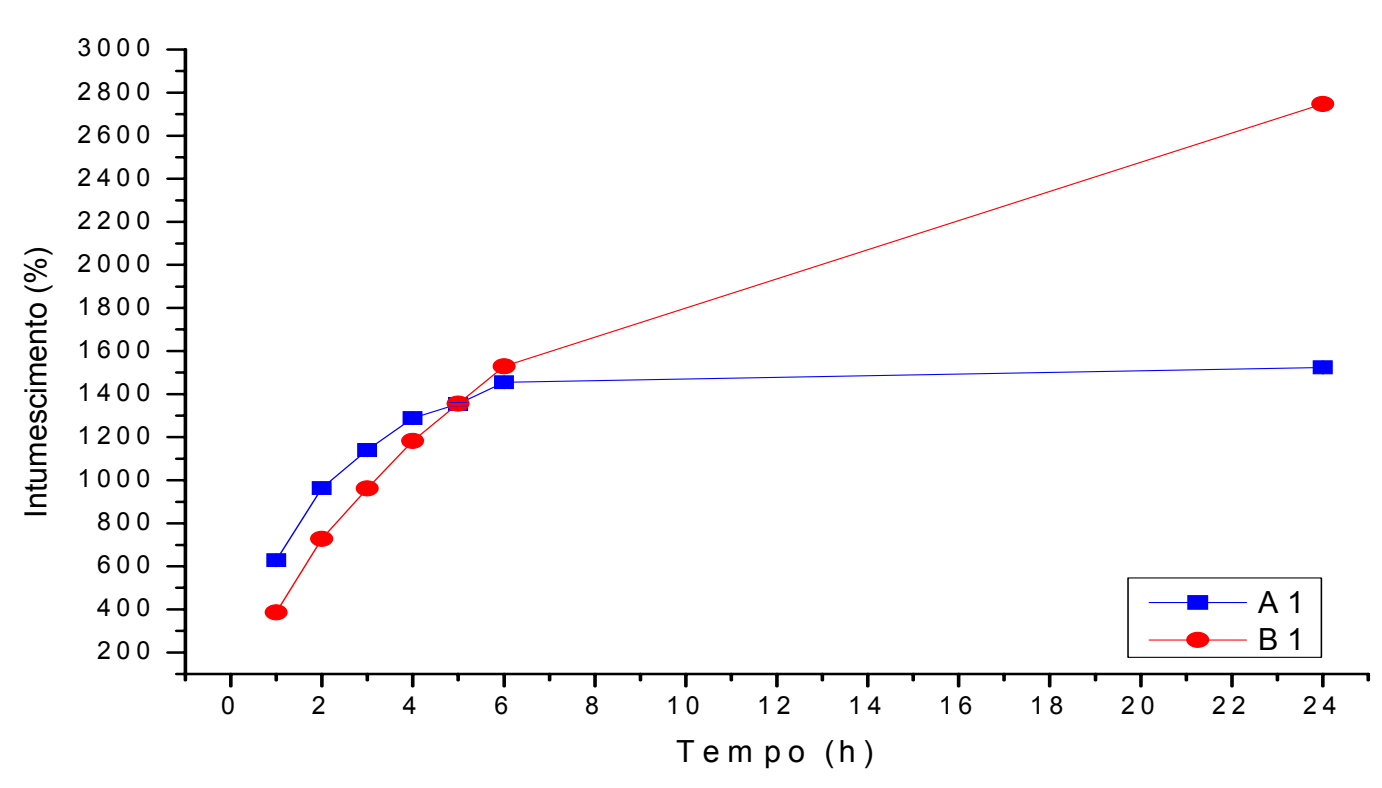

FIGURA 28 - Curvas de intumescimento dos dispositivos de hidrogel de PVP

Ao considerarmos o intumescimento gerado no polímero durante o processo de obtenção dos dispositivos, obtemos um resultado final de $2673,79 \%$ para o dispositivo A1 e de 3046,68\% para o B1. Da mesma maneira que ocorreu no ensaio de fração gel, o intumescimento do dispositivo A1 foi aproximadamente 10\% inferior ao do dispositivo B1.

\subsubsection{Propriedades mecânicas}

A força máxima de perfuração e a deformação dos dispositivos são apresentadas nas TAB. 20 e 21 e FIG. 29 e 30. Da mesma maneira que a matriz B, o dispositivo B1 apresentou-se mais elástico. Ambos os dispositivos receberam uma força inferior a aplicada nas matrizes, o que demonstra que, apesar de mais elásticos, os dispositivos são menos resistentes. 
TABELA 20 - Força máxima de perfuração e deformação do dispositivo A1 obtida no ensaio de perfuração

\begin{tabular}{ccccc}
\hline Amostra & Força (N) & $\begin{array}{c}\text { Deslocamento } \\
\text { probe }(\mathbf{m m})\end{array}$ & $\boldsymbol{\Delta l}$ & Deformação (\%) \\
\hline \hline 1 & 0,40 & 17,348 & 7,933 & 52,891 \\
2 & 0,39 & 19,262 & 9,413 & 62,757 \\
3 & 0,36 & 21,812 & 11,472 & 76,480 \\
\hline Média & $0,38 \pm 0,02$ & $19,474 \pm 2,240$ & $9,606 \pm 1,777$ & $64,043 \pm 11,847$ \\
\hline
\end{tabular}

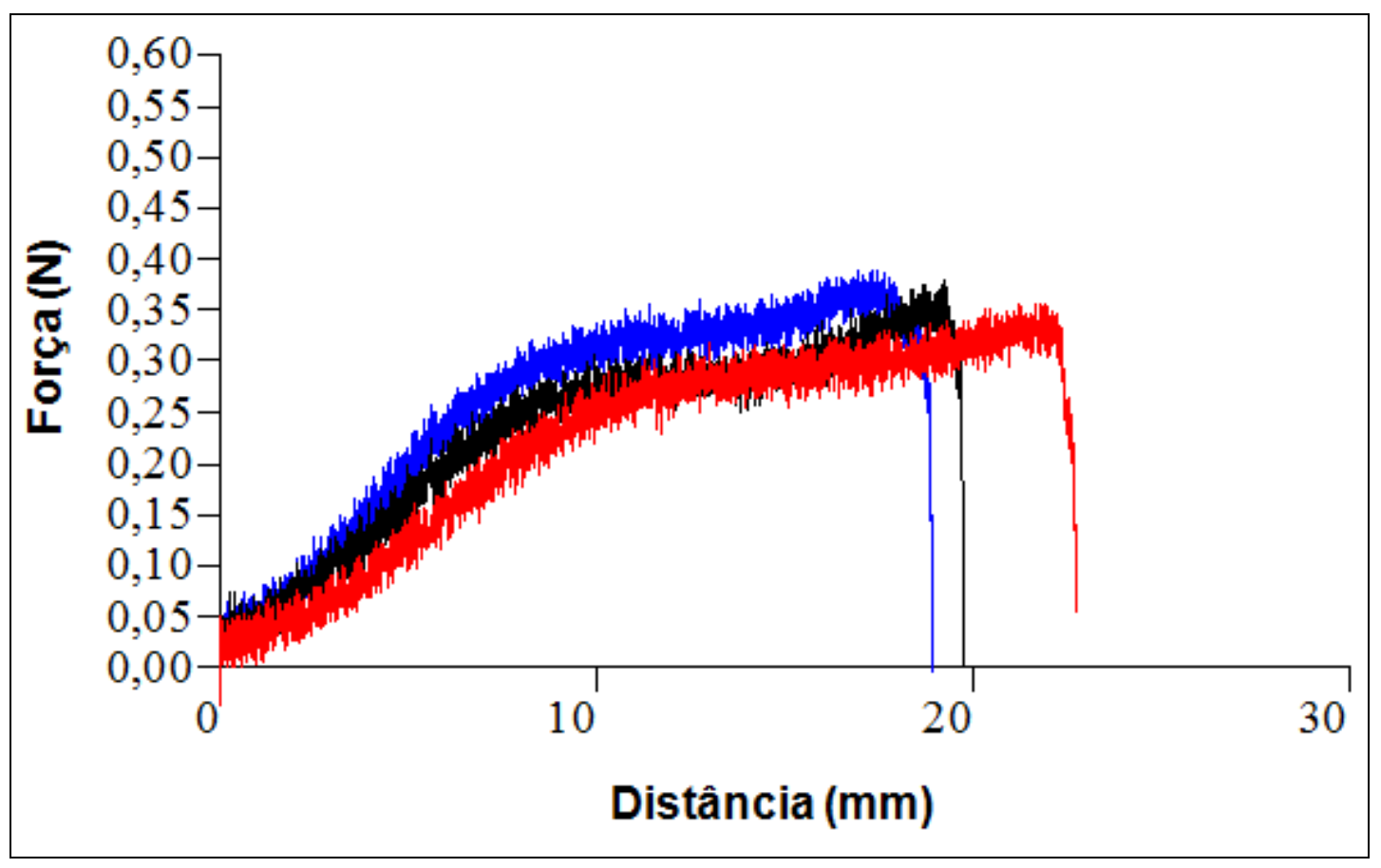

FIGURA 29 - Curva de força aplicada ao dispositivo A1 para perfuração em função da distância percorrida pelo probe até a perfuração do mesmo 
TABELA 21 - Força máxima de perfuração e deformação do dispositivo B1 obtida no ensaio de perfuração

\begin{tabular}{ccccc}
\hline Amostra & Força (N) & $\begin{array}{c}\text { Deslocamento } \\
\text { probe }(\mathbf{m m})\end{array}$ & $\Delta \mathbf{l}$ & Deformação (\%) \\
\hline \hline 1 & 0,1590 & 39,098 & 24,803 & 165,35 \\
2 & 0,3082 & 40,365 & 22,085 & 147,23 \\
3 & 0,2065 & 42,586 & 35,584 & 237,23 \\
\hline \multirow{2}{*}{ Média } & $0,225 \pm 0,076$ & $40,683 \pm 1,766$ & $27,469 \pm 1,6576$ & $189,090 \pm$ \\
& & & & 11,050 \\
\hline
\end{tabular}

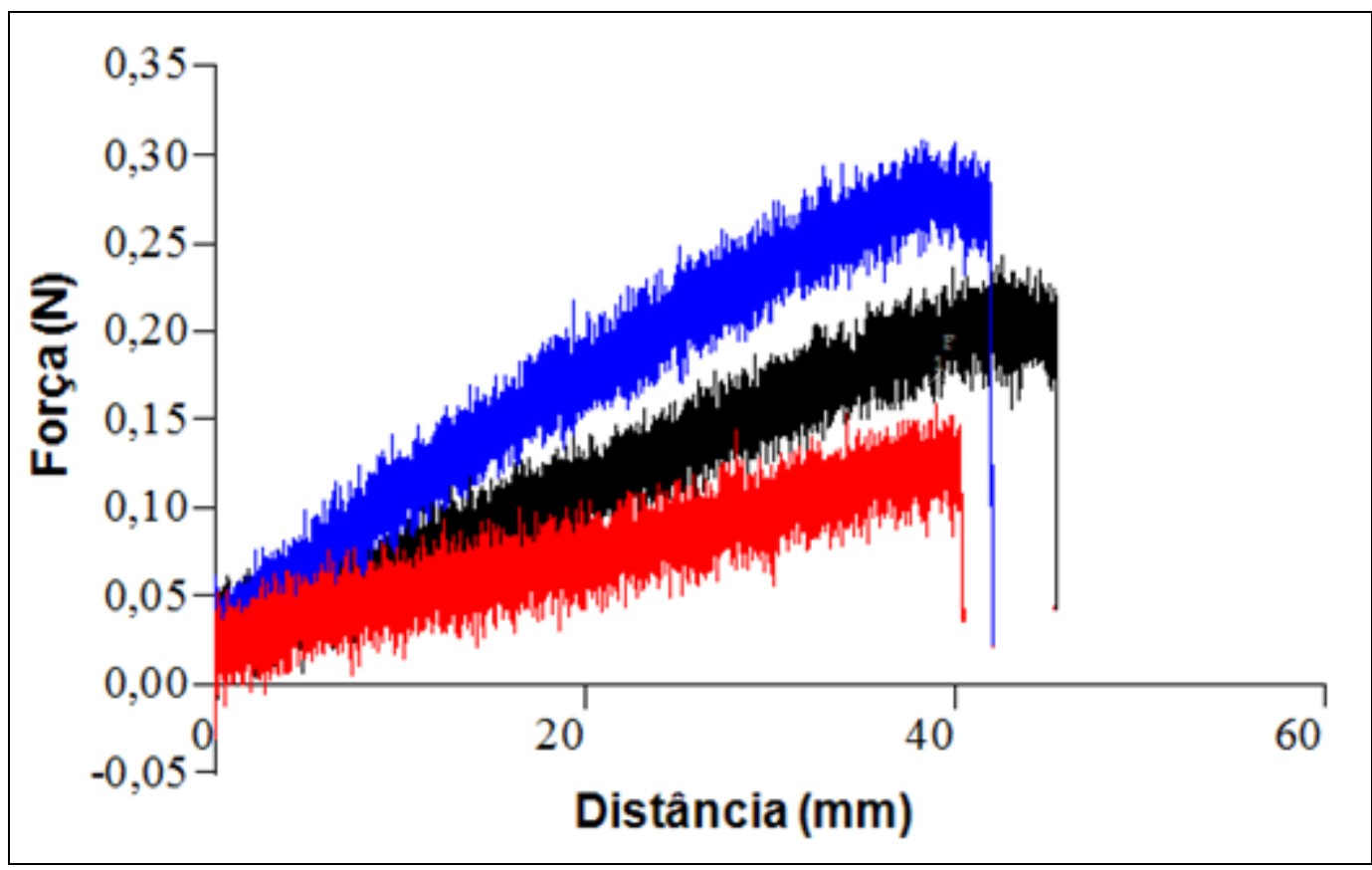

FIGURA 30 - Curva de força aplicada ao dispositivo B1 para perfuração em função da distância percorrida pelo probe até a perfuração do mesmo

\subsubsection{Citotoxicidade}

Os dispositivos de hidrogel de PVP também apresentaram comportamento semelhante ao do controle negativo, demonstrando um comportamento não citotóxico. Quanto ao controle positivo, foi observado que a curva de viabilidade celular cruzou a linha do $\mathrm{IC}_{50 \%}$, e na intersecção pode ser 
obtido o valor do índice de citotoxicidade de 31\%. As curvas de viabilidade celular dos dispositivos de hidrogel de PVP estão apresentadas na TAB. 22 e FIG. 31.

TABELA 22 - Resultados de viabilidade celular dos dispositivos de hidrogel de PVP

\begin{tabular}{ccccc}
\hline $\begin{array}{c}\text { Concentração } \\
\text { do extrato (\%) }\end{array}$ & $\begin{array}{c}\text { Controle } \\
\text { Positivo }\end{array}$ & $\begin{array}{c}\text { Controle } \\
\text { Negativo }\end{array}$ & A1 & B1 \\
\hline 100 & 0 & $89 \pm 13$ & $96 \pm 9$ & $87 \pm 13$ \\
50 & $18 \pm 14$ & $98 \pm 6$ & $100 \pm 7$ & $94 \pm 20$ \\
25 & $60 \pm 6$ & $90 \pm 10$ & $110 \pm 2$ & $80 \pm 20$ \\
12,5 & $74 \pm 6$ & $99 \pm 13$ & $110 \pm 2$ & $85 \pm 19$ \\
6,25 & $79 \pm 19$ & $93 \pm 9$ & $91 \pm 5$ & $92 \pm 18$ \\
\hline
\end{tabular}

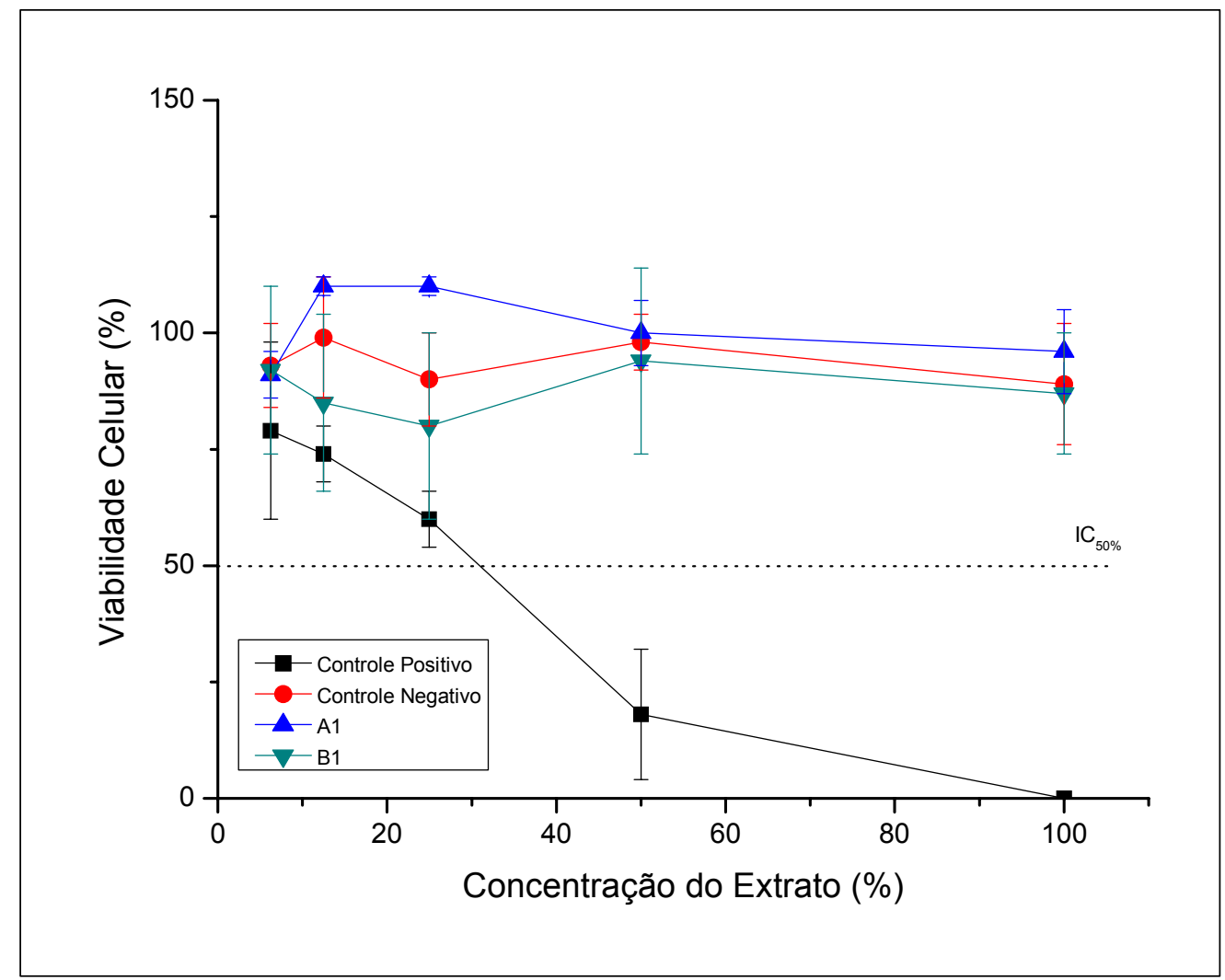

FIGURA 31 - Curvas de viabilidade celular dos dispositivos de hidrogel de PVP no teste de citotoxicidade pelo método de incorporação do vermelho neutro 


\subsubsection{Irritação cutânea primária}

Como pode ser observado na TAB. 23, e na FIG. 32 todos os animais testados apresentaram graus de eritema e de edema iguais a 0 (zero), o que significa pele normal e ausência de edema, respectivamente. Isso demonstra que os dispositivos não causaram irritação cutânea primária no ensaio in vivo.

TABELA 23 - Leitura da graduação de edema e eritema dos dispositivos de hidrogel de PVP

\begin{tabular}{ccccccccc}
\hline \multirow{2}{*}{$\begin{array}{c}\text { Animal } \\
\mathbf{n}^{\circ}\end{array}$} & \multicolumn{2}{c}{ Edema } & \multicolumn{2}{c}{ Eritema } & \multicolumn{2}{c}{ Edema } & \multicolumn{2}{c}{ Eritema } \\
& A1 & B1 & A1 & B1 & A1 & B1 & A1 & B1 \\
\hline 1 & 0 & 0 & 0 & 0 & 0 & 0 & 0 & 0 \\
2 & 0 & 0 & 0 & 0 & 0 & 0 & 0 & 0 \\
3 & 0 & 0 & 0 & 0 & 0 & 0 & 0 & 0 \\
4 & 0 & 0 & 0 & 0 & 0 & 0 & 0 & 0 \\
5 & 0 & 0 & 0 & 0 & 0 & 0 & 0 & 0 \\
6 & 0 & 0 & 0 & 0 & 0 & 0 & 0 & 0 \\
\hline
\end{tabular}

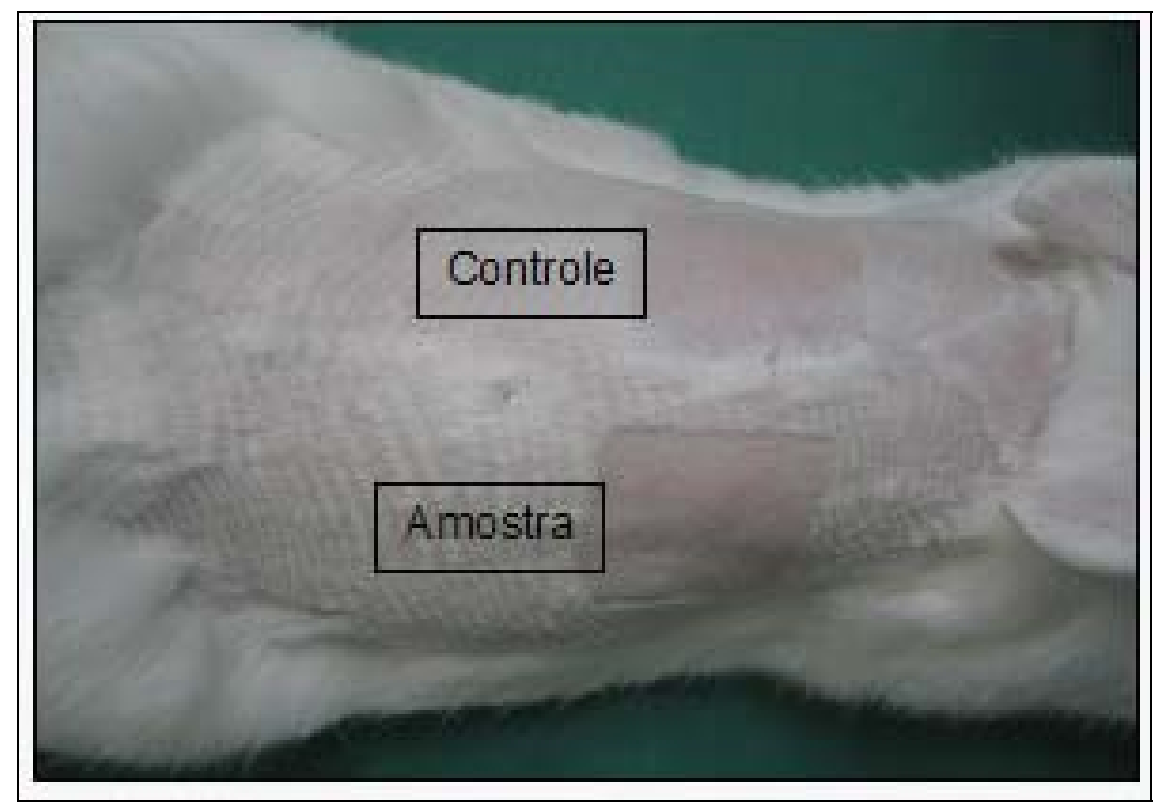

FIGURA 32 - Região dorsal do coelho submetido ao ensaio de irritação cutânea primária: nenhuma reação cutânea é observada 


\subsubsection{Morfologia dos dispositivos}

Nas micrografias obtidas pela microscopia eletrônica de varredura observou-se que o dispositivo A1 está menos reticulado, com uma maior formação de poros (FIG. 33). O dispositivo B1 apresentou-se mais denso, menos poroso, devido à ação plastificante da glicerina (FIG. 34).

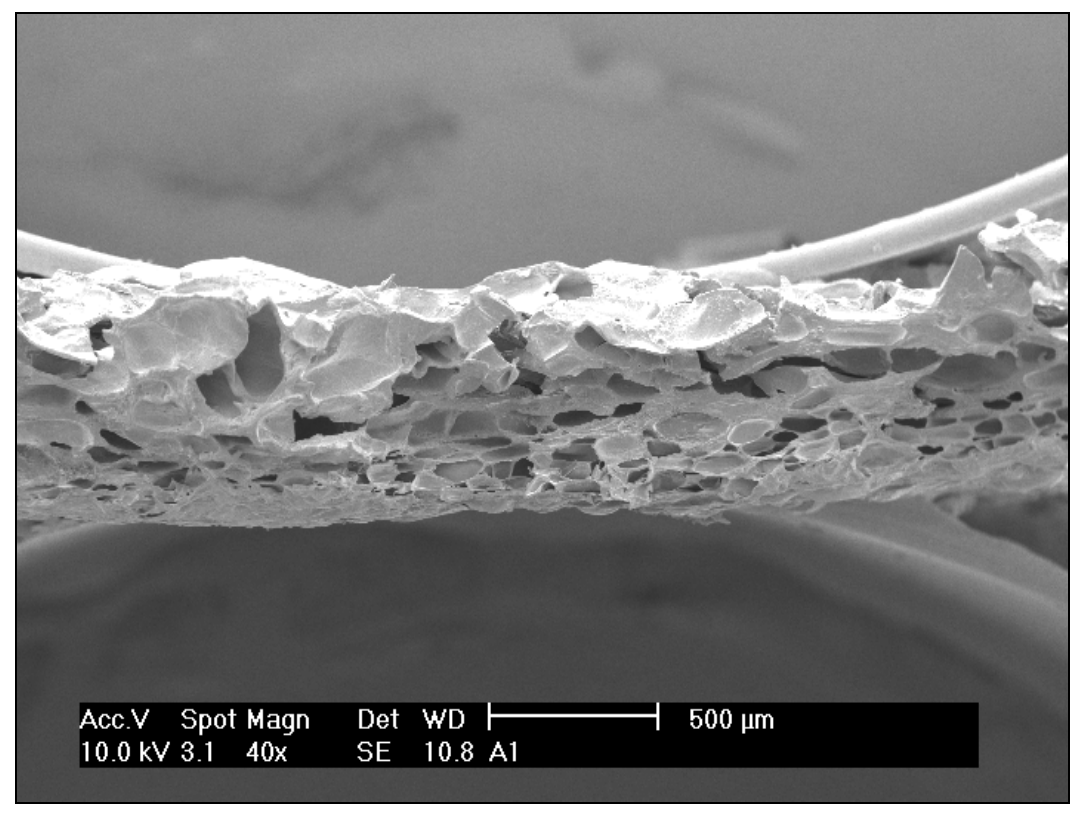

FIGURA 33 - Micrografia panorâmica obtida em MEV do dispositivo A1

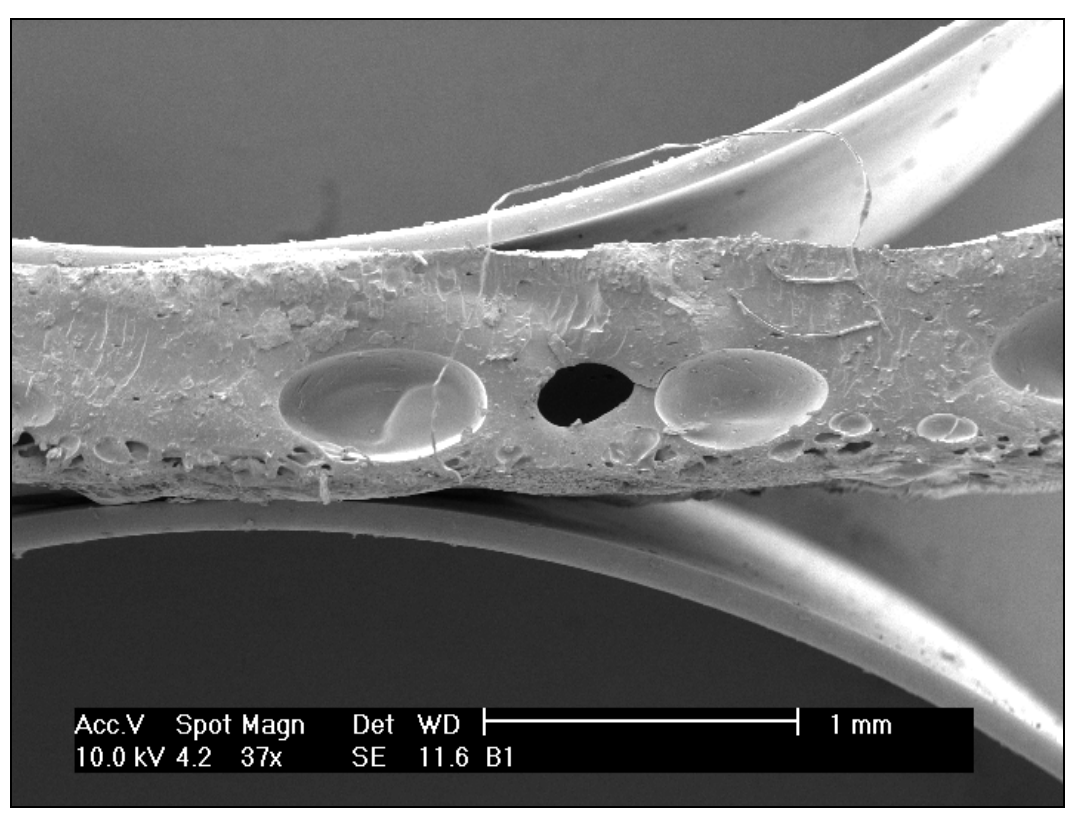

FIGURA 34 - Micrografia panorâmica obtida em MEV do dispositivo B1 
Como a liberação dos ativos por meio dos hidrogéis ocorre pelos processos simultâneos de intumescimento e difusão, a micrografia panorâmica dos dispositivos nos mostra que há maior probabilidade de uma maior liberação do óleo de açaí por meio do dispositivo $\mathbf{A 1}$, no qual há uma maior quantidade de poros do que no dispositivo B1.

Um maior aumento da objetiva mostra que o óleo de açaí encontra-se disposto livremente por toda a superfície da matriz, para os dois dispositivos (FIG. 35 e 36), demonstrado que pode ser facilmente liberado.

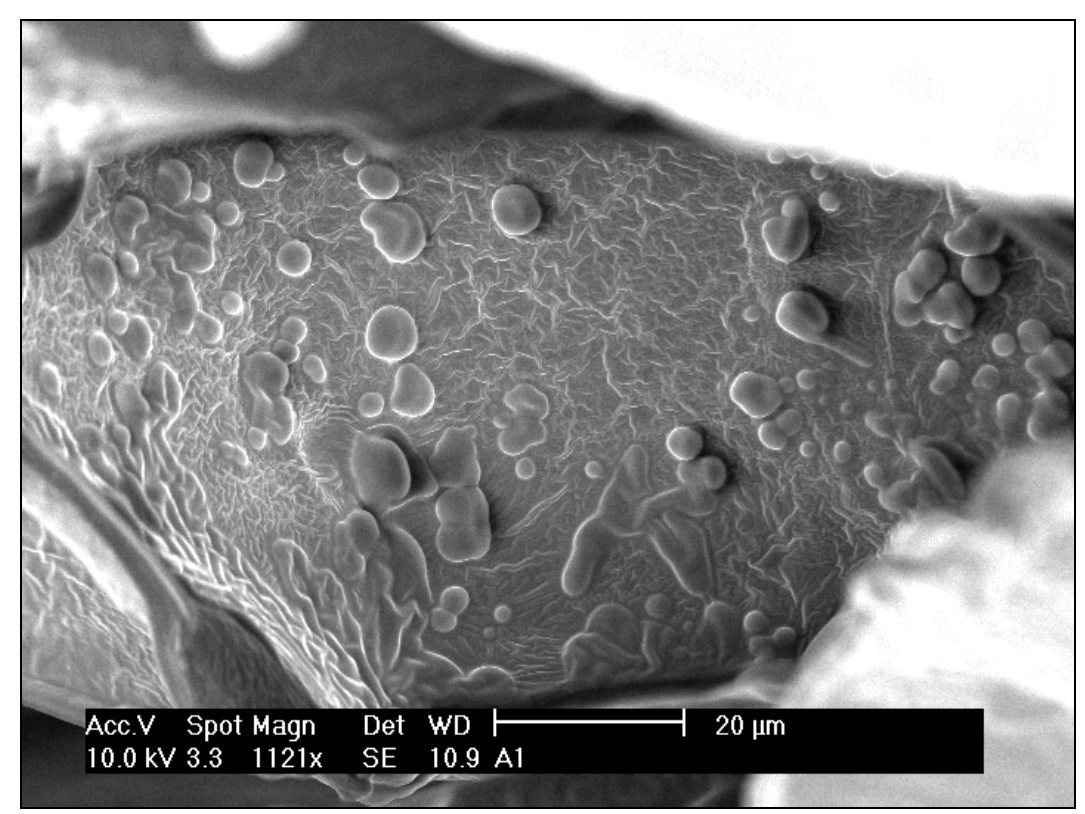

FIGURA 35 - Micrografia obtida em MEV da superfície do dispositivo A1

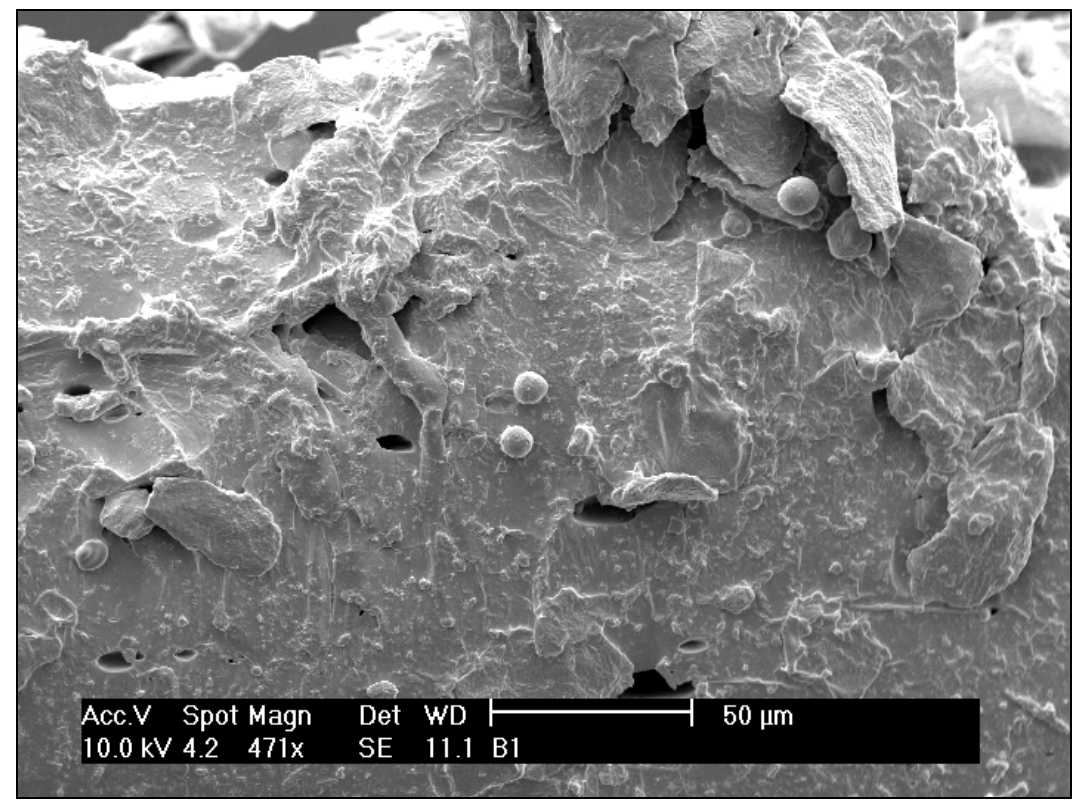

FIGURA 36 - Micrografia obtida em MEV da superfície do dispositivo B1 
Na MEV pode-se verificar também que no dispositivo A1 o óleo de açaí encontra-se aglomerado e por toda a superfície do dispositivo. Já no dispositivo B1 observou-se um menor tamanho das gotículas de óleo bem como uma menor homogeneidade na disposição do óleo na superfície.

Em ambos dispositivos não foi verificada uma distribuição homogênea do óleo de açaí, podendo gerar uma heterogeneidade na cinética de liberação. Fator que pode ser agravado pela presença de bolhas de ar nos dispositivos.

\subsubsection{Cinética de liberação}

Os dispositivos A1 e B1 foram submetidos à cinética de liberação, conforme descrito no item 4.2.4.8. A concentração de ácido oleico liberada pelos dispositivos foi calculada utilizando a Eq. (6), obtida pela construção da curva padrão. Os cromatogramas obtidos para a construção da curva de calibração podem ser visualizados no Apêndice $A$.

A cada tempo foi coletada uma alíquota e o mesmo volume foi reposto com PBS $0,1 \mathrm{M}$. Portanto, para encontrar a concentração total liberada, foi necessário fazer a correção dos valores obtidos. A concentração de ácido oleico foi multiplicada por $25 \mathrm{~mL}$, encontrando-se o valor correspondente ao volume total de ácido oleico liberado. A este valor foi somada a quantidade obtida em $200 \mu \mathrm{L}$ da coleta anterior. Os resultados da liberação podem ser observados na TAB. 24 e FIG. 37, e os respectivos cromatogramas nos Apêndices B e C. 
TABELA 24 - Quantidade de ácido oleico liberado no ensaio de cinética de liberação

\begin{tabular}{cccc}
\hline Dispositivo & $\begin{array}{c}\text { Tempo de } \\
\text { liberação }(\mathbf{h})\end{array}$ & $\begin{array}{c}\text { Área do pico } \\
(\mathbf{u} . \mathbf{a})\end{array}$ & $\begin{array}{c}\text { Ácido oleico } \\
(\boldsymbol{\mu g} / \mathrm{mL})\end{array}$ \\
\hline 1 & $9097 \pm 286$ & $11,21 \pm 0,06$ \\
2 & $5338 \pm 285$ & $10,27 \pm 0,06$ \\
3 & $3821 \pm 43$ & $10,14 \pm 0,01$ \\
& 4 & $4324 \pm 182$ & $10,25 \pm 0,04$ \\
& 5 & $3665 \pm 372$ & $10,11 \pm 0,08$ \\
& 6 & $3896 \pm 100$ & $10,16 \pm 0,02$ \\
& 24 & $3082 \pm 93$ & $9,98 \pm 0,02$ \\
& 1 & $6663 \pm 208$ & $10,68 \pm 0,05$ \\
& 2 & $4230 \pm 80$ & $10,23 \pm 0,02$ \\
& 3 & $3987 \pm 29$ & $10,10 \pm 0,01$ \\
& 4 & $2306 \pm 39$ & $9,81 \pm 0,01$ \\
& 5 & $3808 \pm 87$ & $10,14 \pm 0,02$ \\
& 6 & $3363 \pm 61$ & $10,04 \pm 0,01$ \\
& 24 & $3677 \pm 108$ & $10,11 \pm 0,02$ \\
& & & \\
& & &
\end{tabular}

No ensaio de cinética de liberação foi utilizada a metade do dispositivo. Para obter a concentração de ácido oleico do dispositivo inteiro, o valor obtido foi multiplicado por 2. $\mathrm{Na}$ análise qualitativa do óleo de açaí, foi observado que o ácido oleico representa $50,54 \%$ do total do óleo de açaí. Assim foi feita a correlação entre o ácido oleico encontrado e a quantidade de óleo de açaí liberada por meio dos dispositivos (TAB. 25) 
TABELA 25 - Quantidade de óleo de açaí presente nos dispositivos de hidrogel de PVP em relação à quantidade de ácido oleico

\begin{tabular}{cccc}
\hline Dispositivo & Tempo $(\mathbf{h})$ & $\begin{array}{c}\text { Ácido oleico } \\
(\boldsymbol{\mu g} / \mathbf{m L})\end{array}$ & $\begin{array}{c}\text { Óleo de açaí } \\
(\boldsymbol{\mu g} / \mathbf{m L})\end{array}$ \\
\hline \hline & 1 & 22,43 & 44,40 \\
& 2 & 20,54 & 40,67 \\
A1 & 3 & 20,28 & 40,15 \\
& 4 & 20,50 & 40,59 \\
& 5 & 20,22 & 40,04 \\
& 6 & 20,32 & 40,23 \\
& 24 & 19,96 & 39,52 \\
\hline & 1 & 21,36 & 42,29 \\
& 2 & 20,46 & 40,52 \\
& 3 & 20,20 & 40,00 \\
& 4 & 19,62 & 38,85 \\
& 5 & 20,28 & 40,16 \\
& 6 & 20,09 & 39,77 \\
& 24 & 20,22 & 40,04 \\
\hline
\end{tabular}




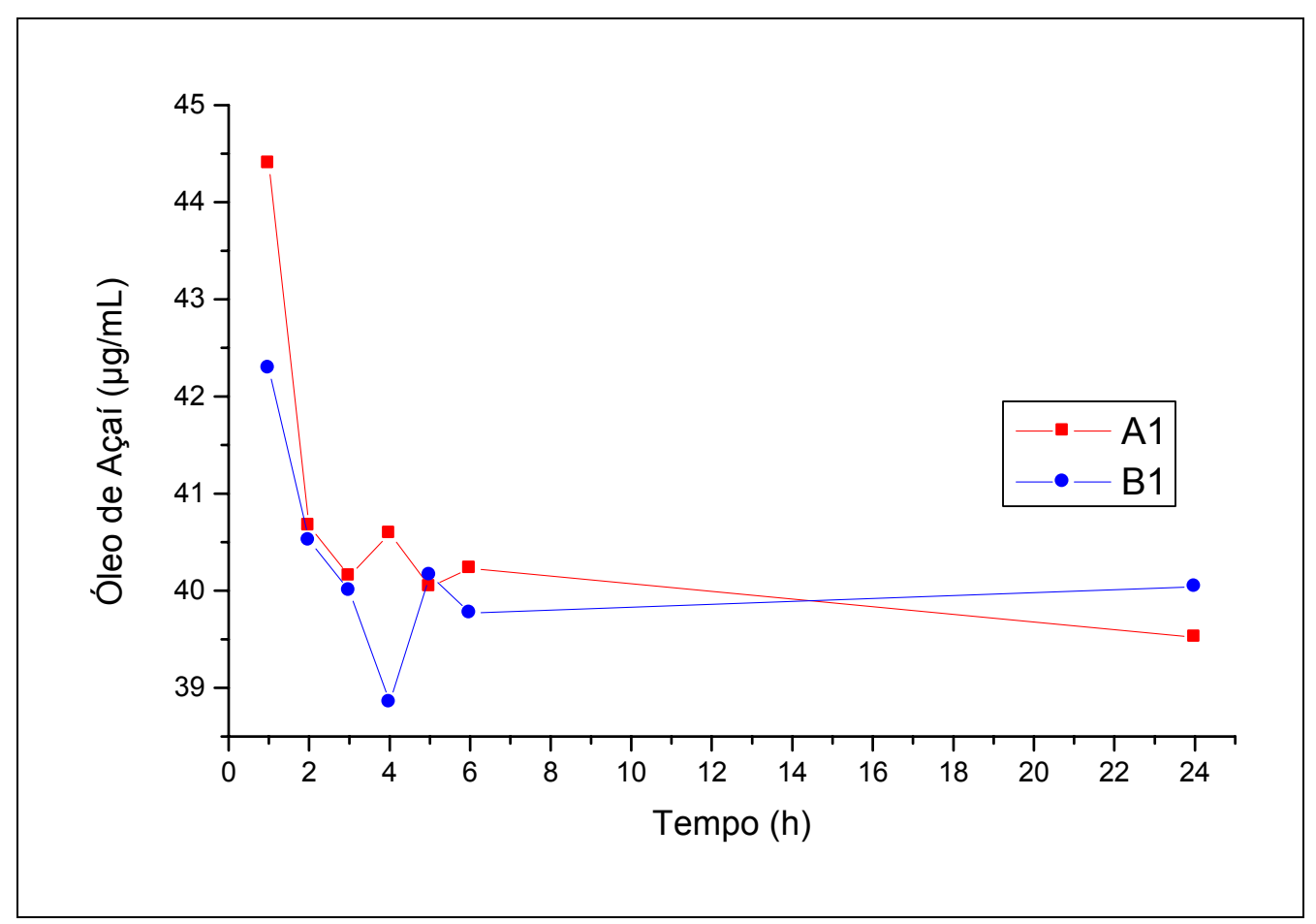

FIGURA 37 - Gráfico da concentração de óleo de açaí liberado em relação ao tempo

Como pode ser observado nas tabelas acima, os dispositivos apresentaram capacidade de liberação do óleo de açaí. As quantidades de óleo de açaí liberados foram próximas em todos os tempos analisados para ambos os dispositivos, demonstrando que a liberação total ocorreu logo no tempo $1 \mathrm{~h}$, resultado que pode ser explicado por o óleo de açaí estar presente na superfície do dispositivo, como observado na MEV.

A porcentagem de liberação em relação à quantidade do óleo de açaí incorporado ao dispositivo foi em média de $81,60 \%$ para o dispositivo $\mathbf{A} 1$ e $80,5 \%$ para o dispositivo B1.

Os ácidos graxos essenciais, como os presentes no óleo de açaí, são utilizados no tratamento de feridas cutâneas por promover aceleração no processo de cicatrização da pele e atuar como bactericidas. Entretanto necessitam de uma cobertura secundária para fazer a sua oclusão, a qual deve ser trocada a cada 24 h (Franco \& Gonçalves, 2008; Mandelbaum et al., 2003).

Os dispositivos de hidrogel de PVP estudados apresentaram uma boa capacidade de liberar o óleo de açaí incorporado, sendo uma alternativa para o uso de cobertura secundária que os ácidos graxos essenciais necessitam. Além 
disso, os hidrogéis possuem a vantagem de também atuar no tratamento de feridas cutâneas por promover um desbridamento das feridas, manterem o meio úmido, permitir a permeabilidade de oxigênio, entre outras vantagens. 


\section{CONCLUSÕES}

O óleo de açaí não sofreu alterações significativas em relação à sua composição de ácidos graxos quando submetido à radiação gama. A preservação de seus ácidos graxos pode ser decorrente da grande quantidade de antioxidantes presentes no óleo de açaí.

Os resultados apresentados demonstraram que as matrizes de hidrogel de PVP obtiveram características adequadas para a incorporação e liberação de óleo de açaí.

Apesar de o óleo de açaí não ser solúvel em matrizes hidrofílicas, a presença de substâncias anfifilicas possibilitaram a sua incorporação de maneira satisfatória.

A presença de uma substância hidrofóbica diminui a interação da radiação com os polímeros, o que resultou numa menor formação da rede polimérica nos dispositivos, mas ainda com propriedades mecânicas adequadas. O retardamento no processo de intumescimento também não gerou uma perda na capacidade de liberação do óleo de açaí e os dois dispositivos foram considerados adequados para compor um sistema de liberação do óleo de açaí.

A biocompatibilidade foi comprovada tanto pelo in vitro pelo teste de citotoxicidade, como in vivo pelo teste de irritação cutânea primária, demonstrando que os dispositivos podem ser utilizados como biomateriais médicos / farmacêuticos.

Os dispositivos se mostraram satisfatórios para compor um sistema de liberação de óleo de açaí, que podem ser utilizado como curativos de feridas, acelerando o processo de cicatrização da pele. 


\section{TRABALHOS FUTUROS}

Seguem como sugestões para continuidade deste estudo as seguintes análises:

- Avaliação da capacidade antioxidante do óleo de açaí, irradiado e não irradiado;

- Avaliação da homogeneidade do óleo de açaí incorporado às matrizes;

- Avaliação da estabilidade dos dispositivos de hidrogel;

- Desenvolvimento de uma melhor metodologia de análise dos ácidos graxos por meio de cromatografia;

- Avaliação in vitro e ex vivo da penetração do óleo de açaí liberado por meio das matrizes de hidrogel de PVP;

- Avaliação da cinética de liberação do óleo de açaí por meio de outras matrizes, como as de silicone. 
APÊNDICE A - Cromatogramas do padrão de ácido oleico

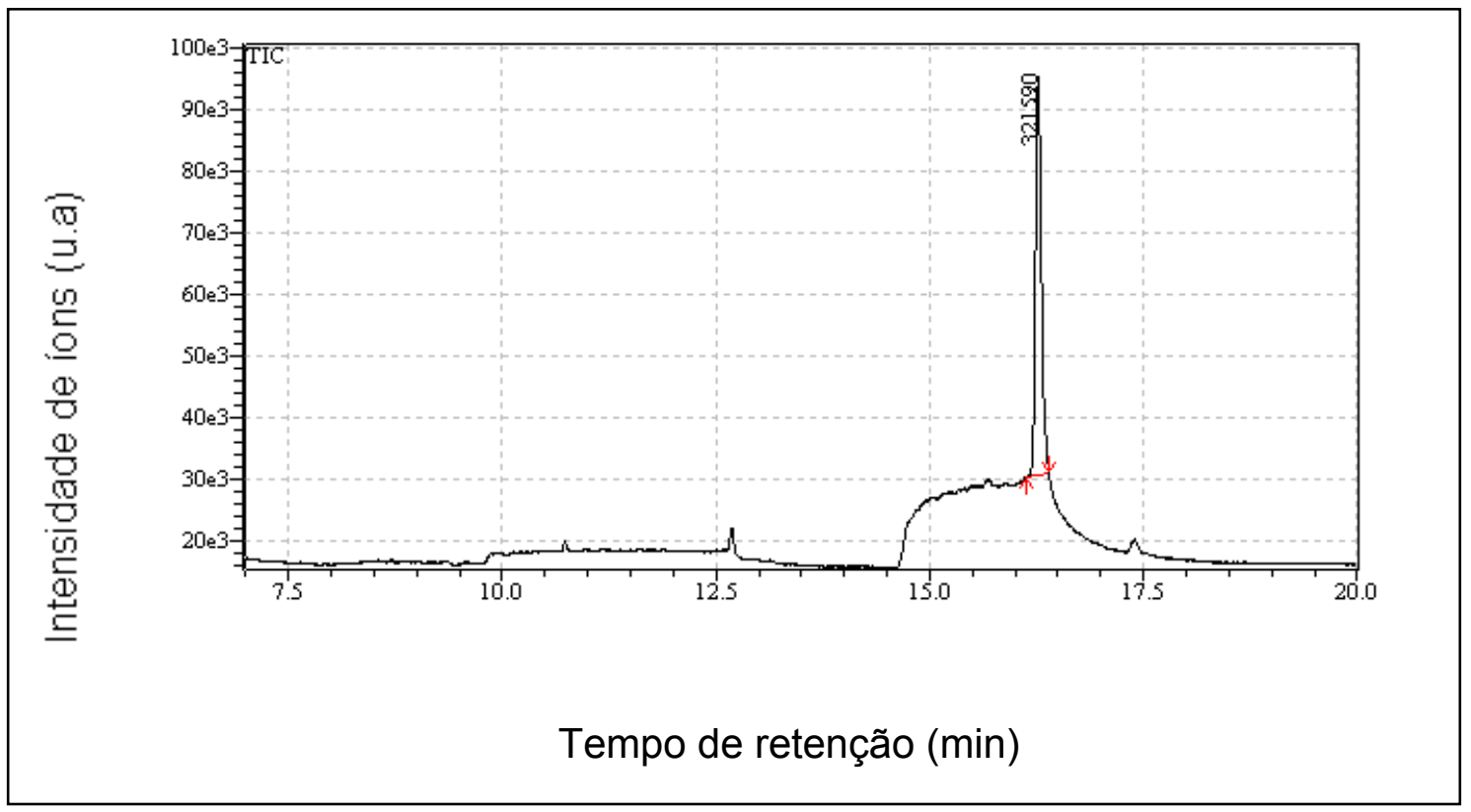

FIGURA 38 - Cromatograma do padrão de ácido oleico $80 \mu \mathrm{g} / \mathrm{mL}$ - $1^{\text {a }}$ injeção

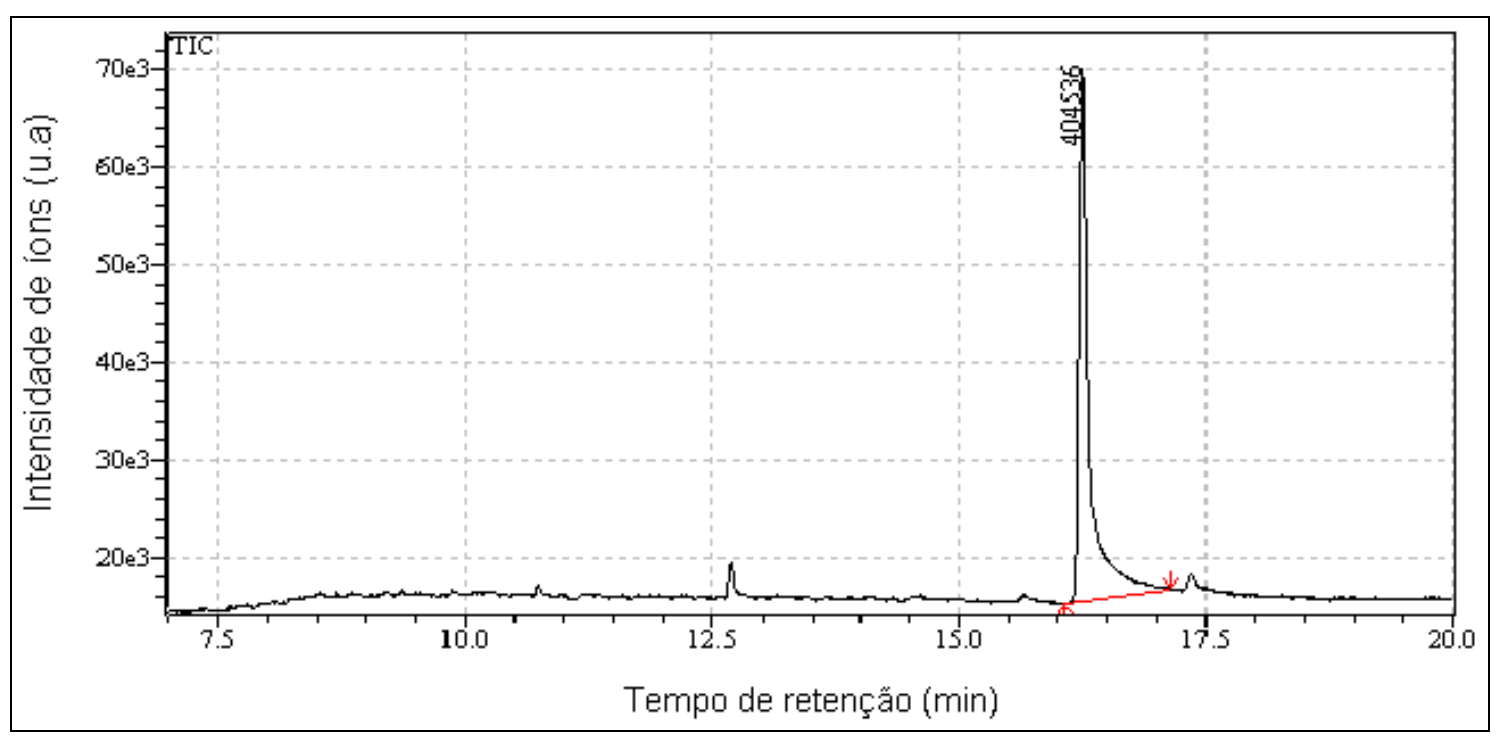

FIGURA 39 - Cromatograma do padrão de ácido oleico $80 \mu \mathrm{g} / \mathrm{mL}$ - 2a injeção 


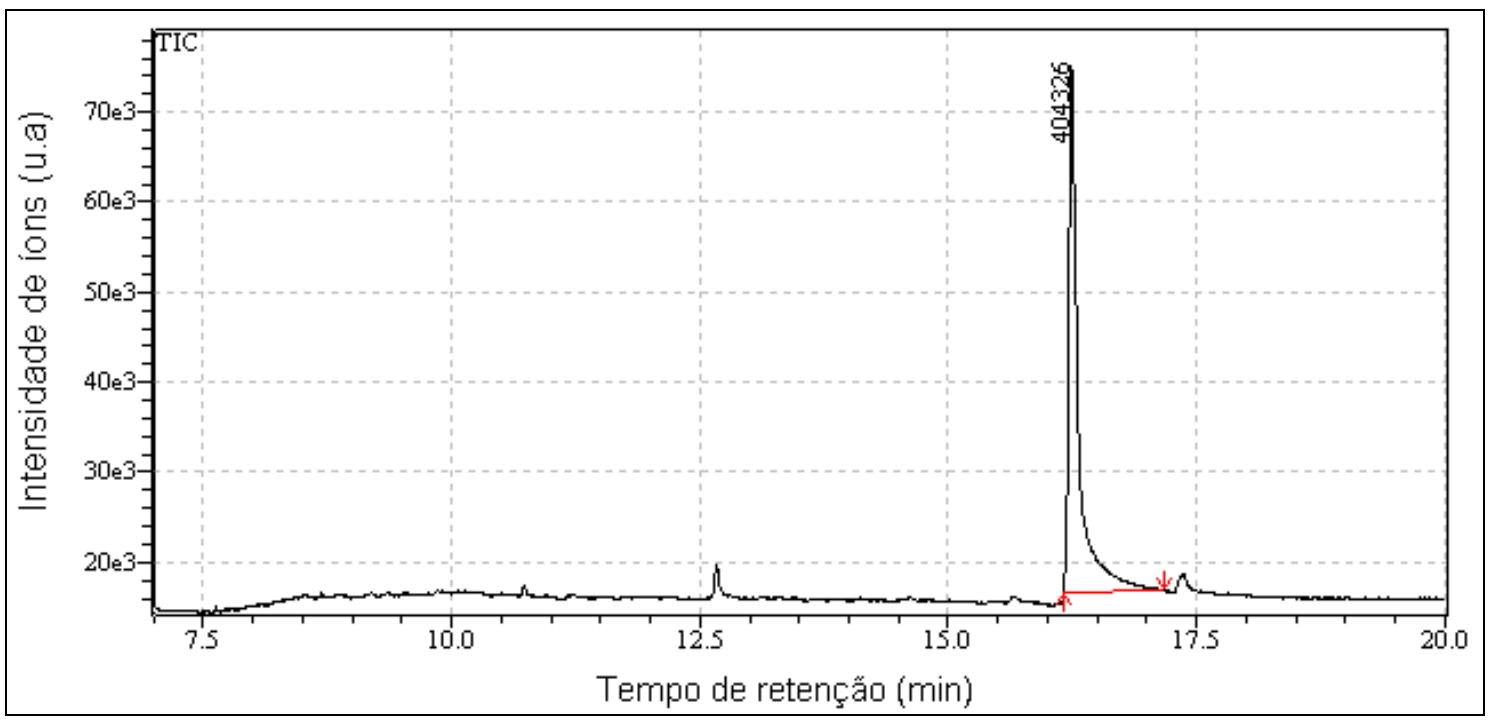

FIGURA 40 - Cromatograma do padrão de ácido oleico $80 \mu \mathrm{g} / \mathrm{mL}$ - $3^{\mathrm{a}}$ injeção

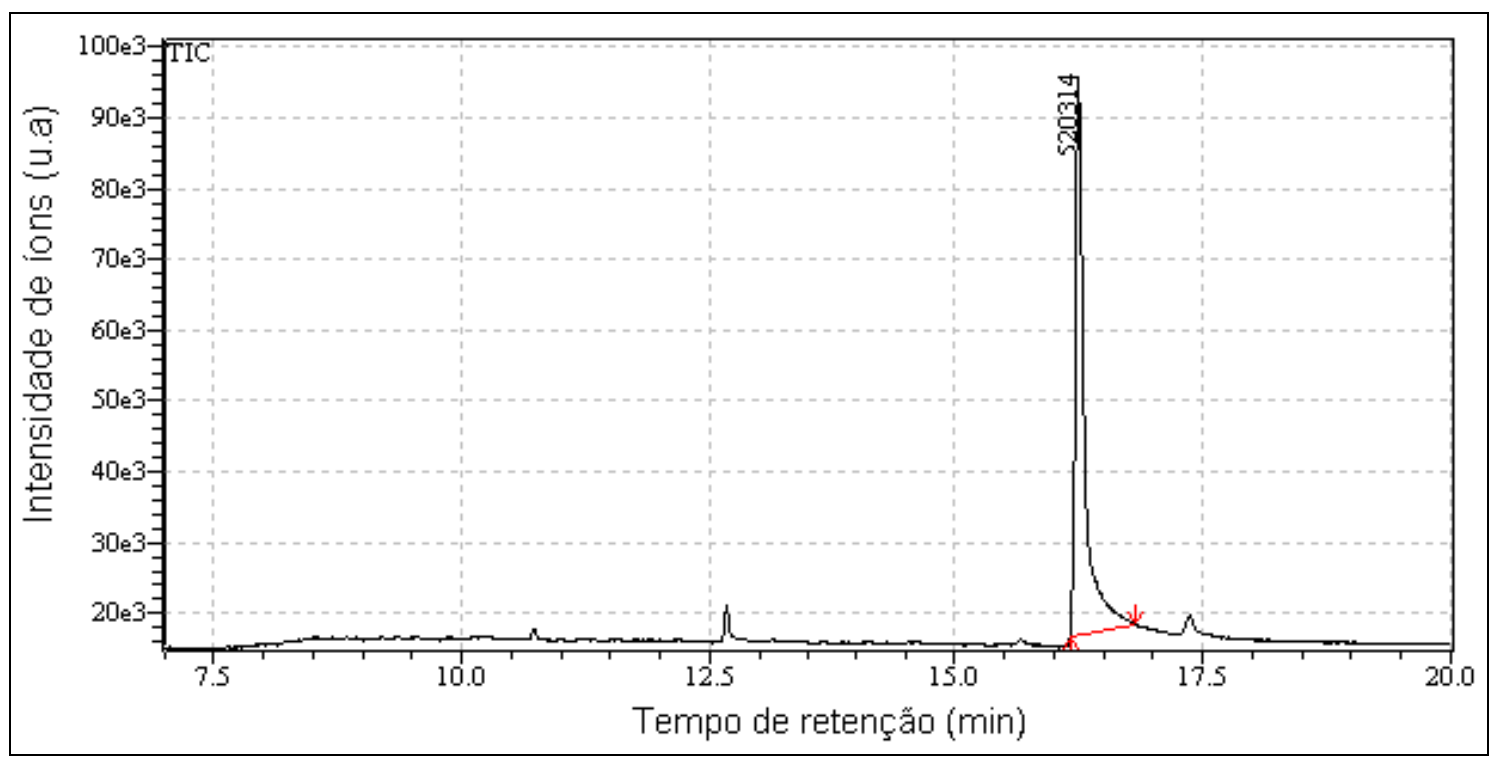

FIGURA 41 - Cromatograma do padrão de ácido oleico $128 \mu \mathrm{g} / \mathrm{mL}$ - $1^{\mathrm{a}}$ injeção 


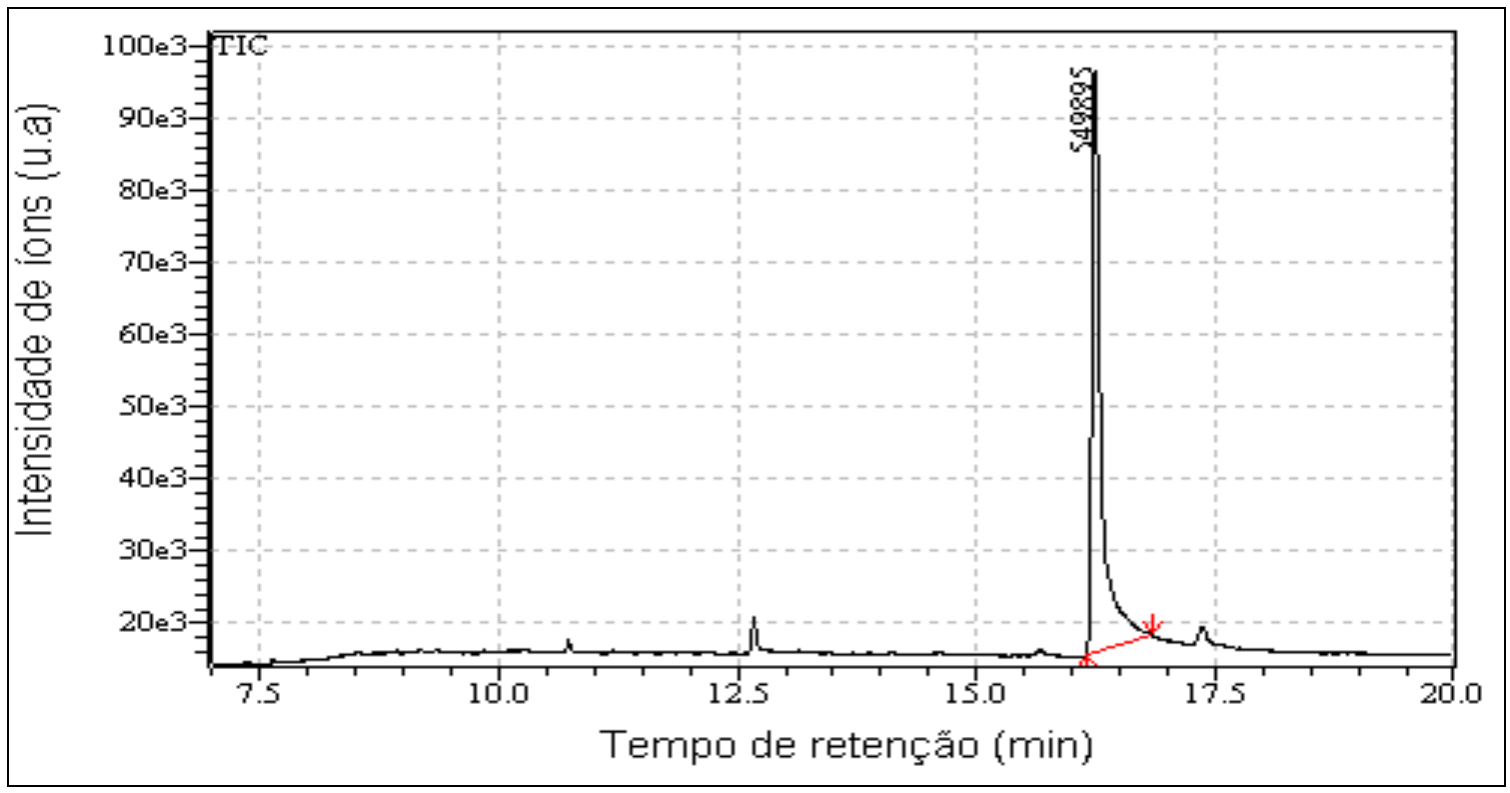

FIGURA 42 - Cromatograma do padrão de ácido oleico $128 \mu \mathrm{g} / \mathrm{mL}-2^{\mathrm{a}}$ injeção

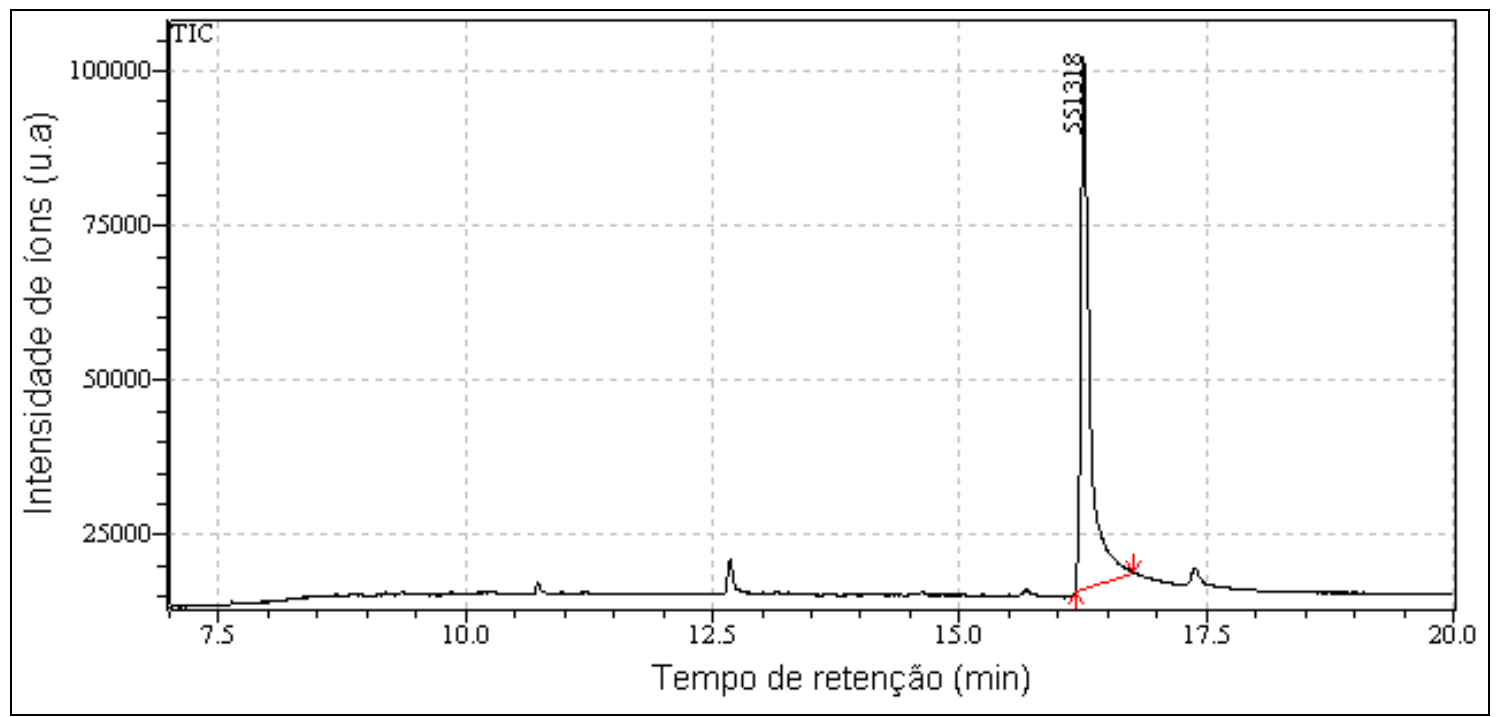

FIGURA 43 - Cromatograma do padrão de ácido oleico $128 \mu \mathrm{g} / \mathrm{mL}$ - $3^{\mathrm{a}}$ injeção 


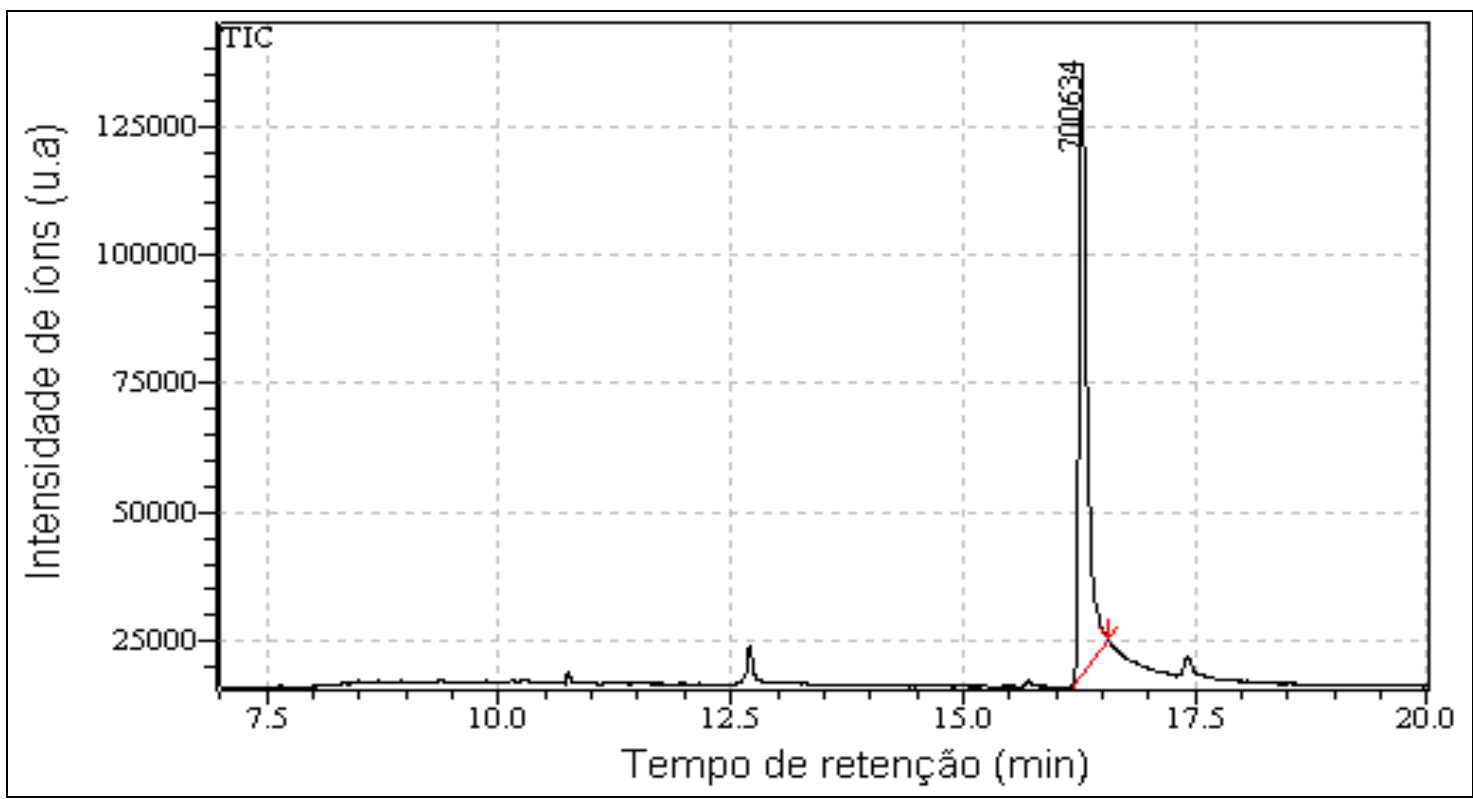

FIGURA 44 - Cromatograma do padrão de ácido oleico $160 \mu \mathrm{g} / \mathrm{mL}$ - $1^{\text {a }}$ injeção

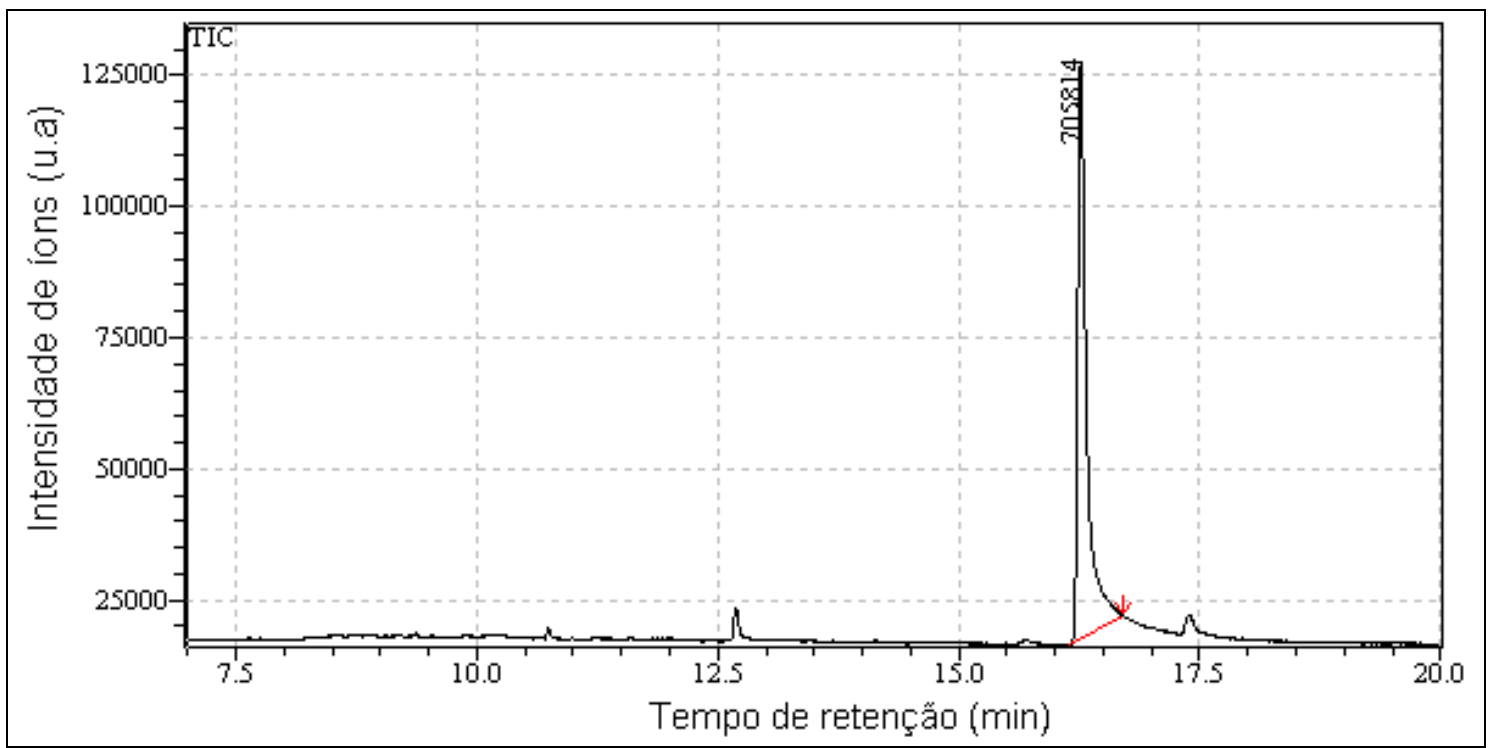

FIGURA 45 - Cromatograma do padrão de ácido oleico $160 \mu \mathrm{g} / \mathrm{mL}$ - 2a injeção 


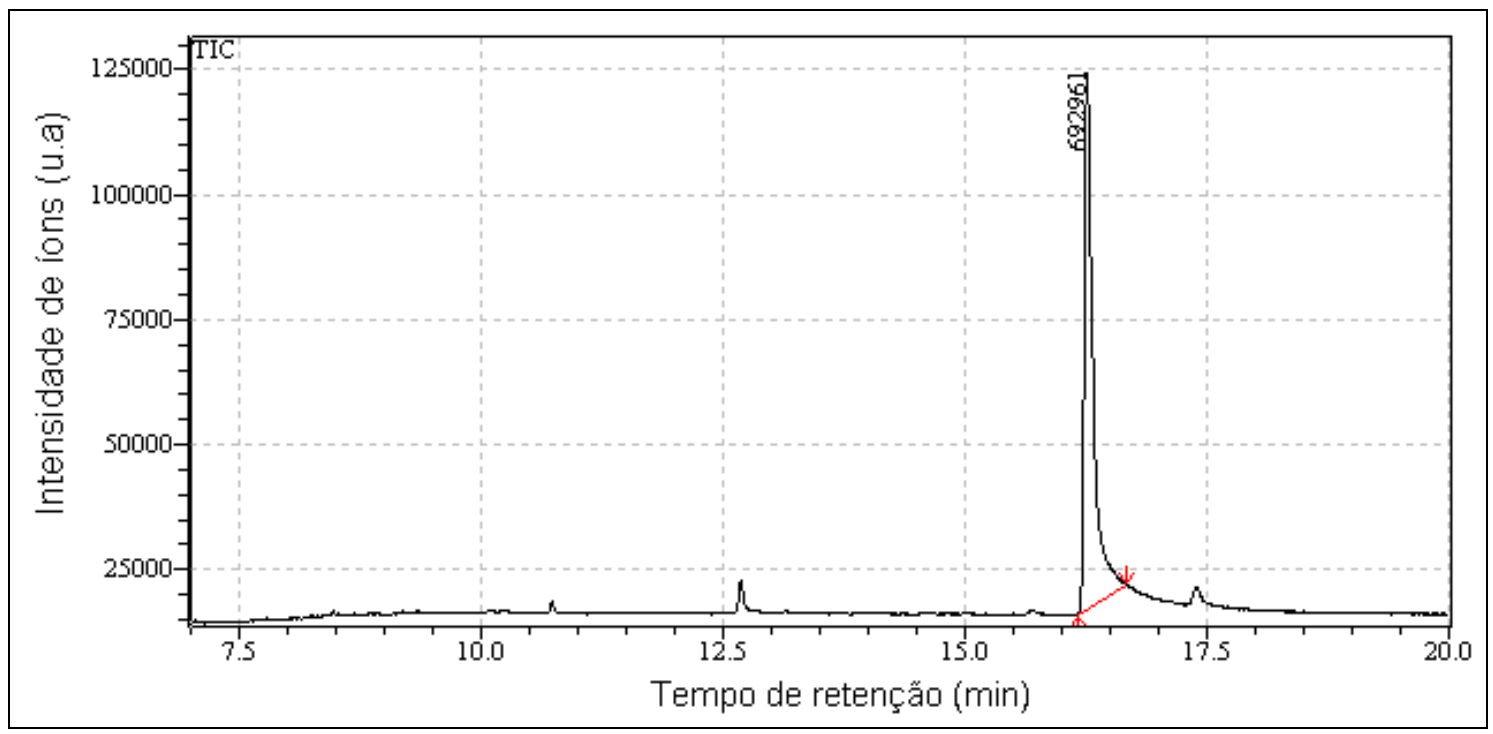

FIGURA 46 - Cromatograma do padrão de ácido oleico $160 \mu \mathrm{g} / \mathrm{mL}$ - $3^{\mathrm{a}}$ injeção

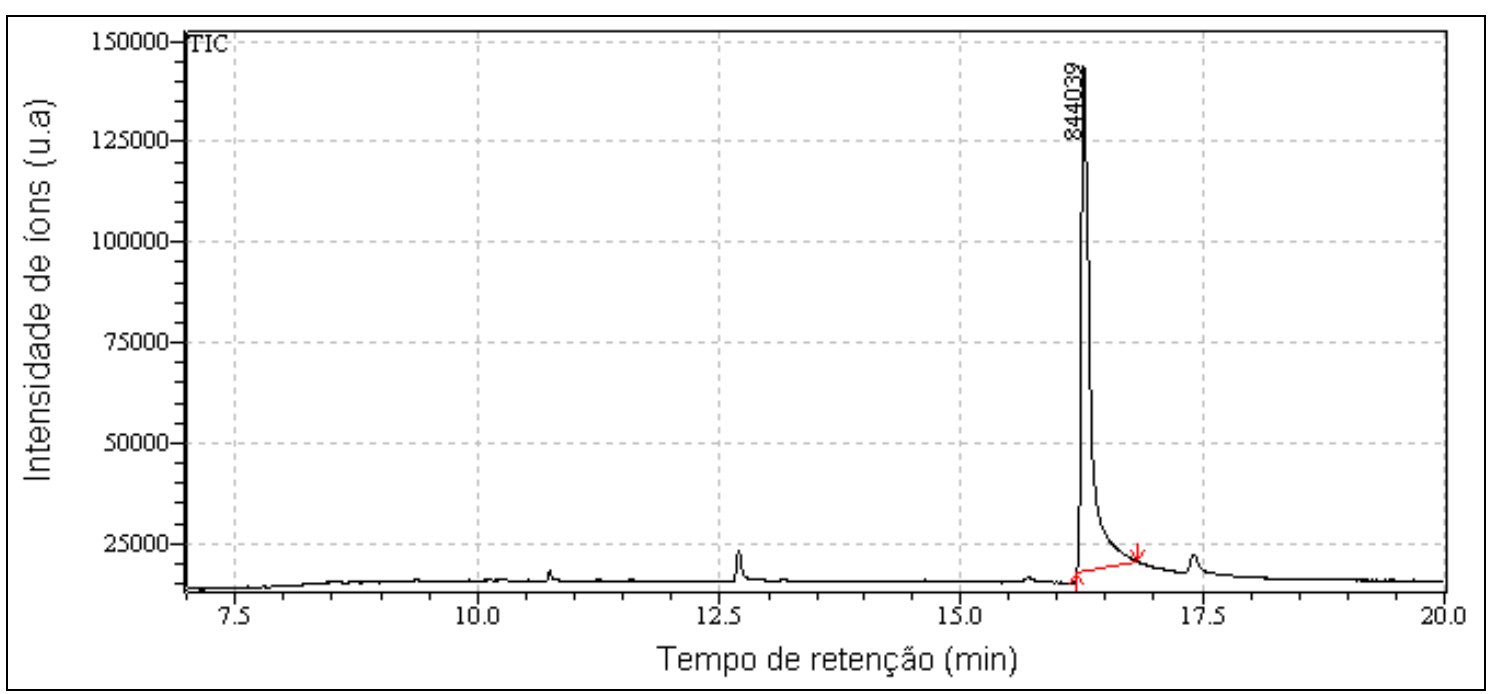

FIGURA 47 - Cromatograma do padrão de ácido oleico $192 \mu \mathrm{g} / \mathrm{mL}$ - $1^{\mathrm{a}}$ injeção 


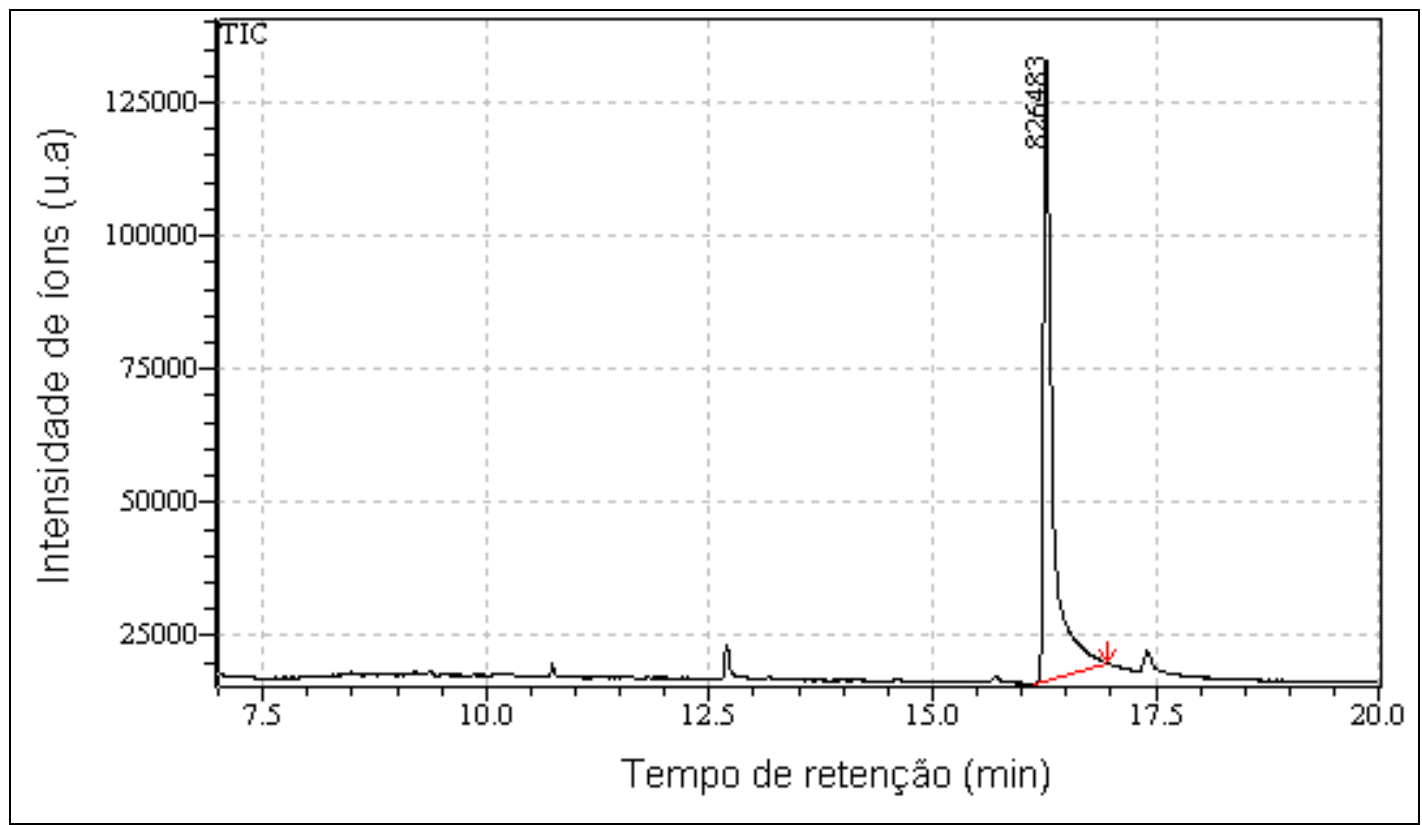

FIGURA 48 - Cromatograma do padrão de ácido oleico $192 \mu \mathrm{g} / \mathrm{mL}$ - 2a injeção

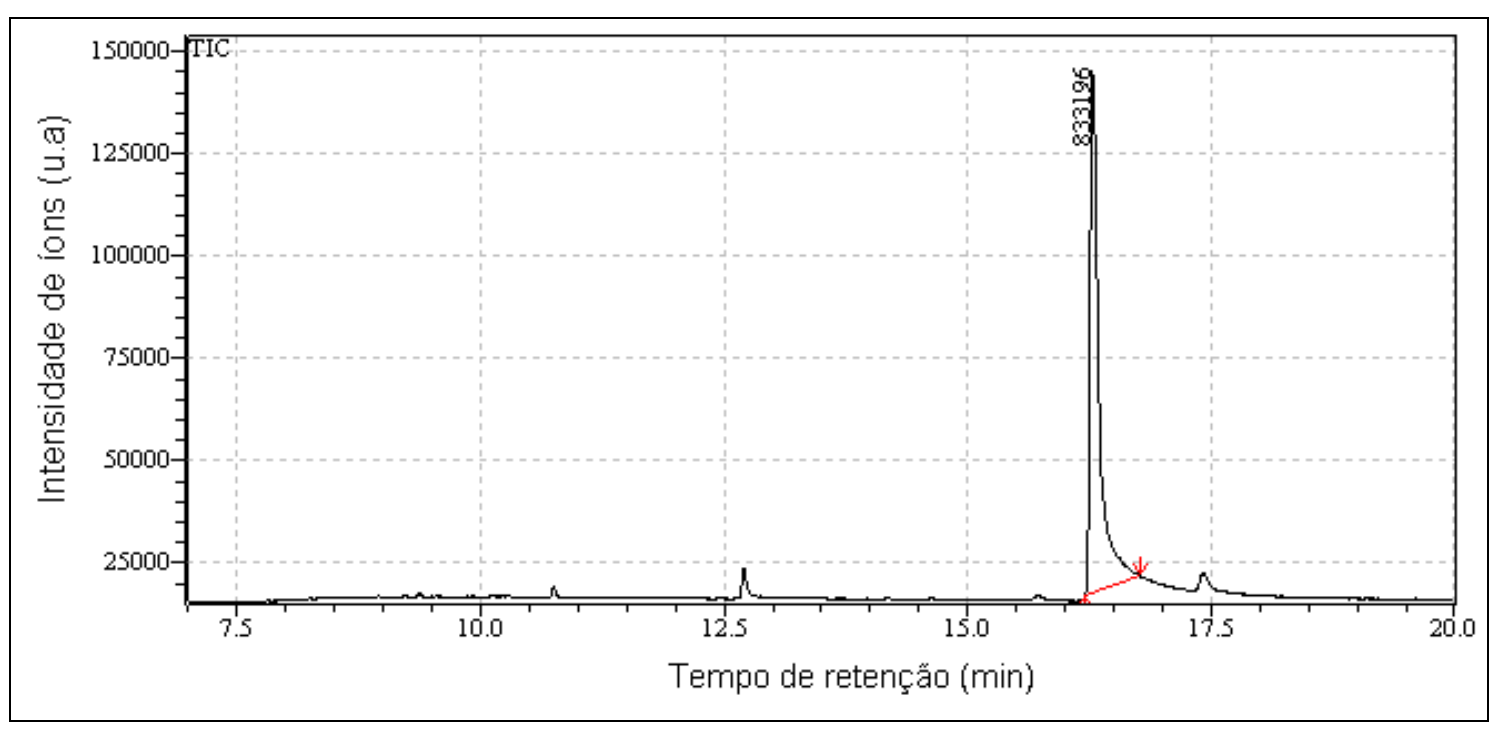

FIGURA 49 - Cromatograma do padrão de ácido oleico $192 \mu \mathrm{g} / \mathrm{mL}$ - $3^{\mathrm{a}}$ injeção 
APÊNDICE B - Cromatogramas da liberação de ácido oleico pelo dispositivo A1

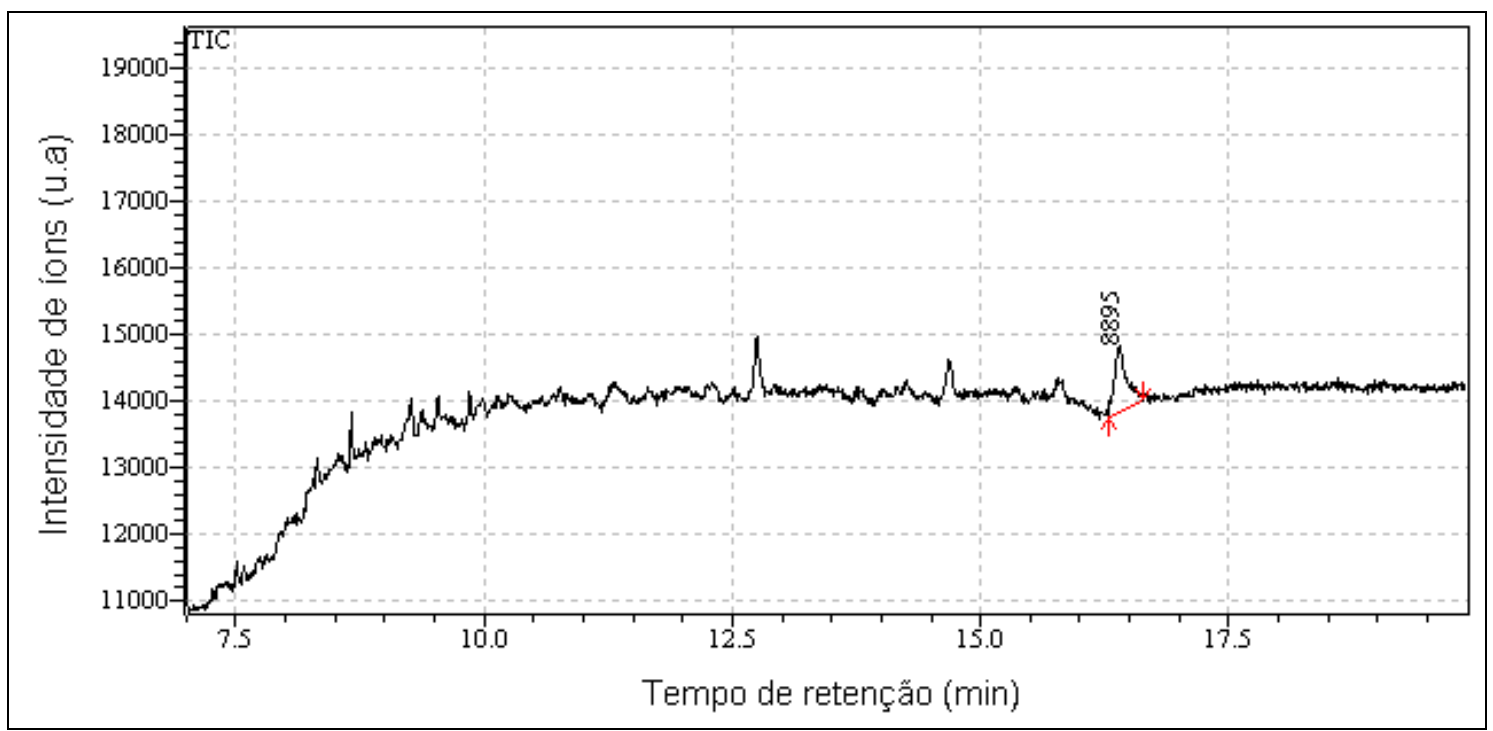

FIGURA 50 - Cromatograma da liberação de ácido oleico pelo dispositivo A1, no tempo $1 \mathrm{~h}-1^{\mathrm{a}}$ injeção

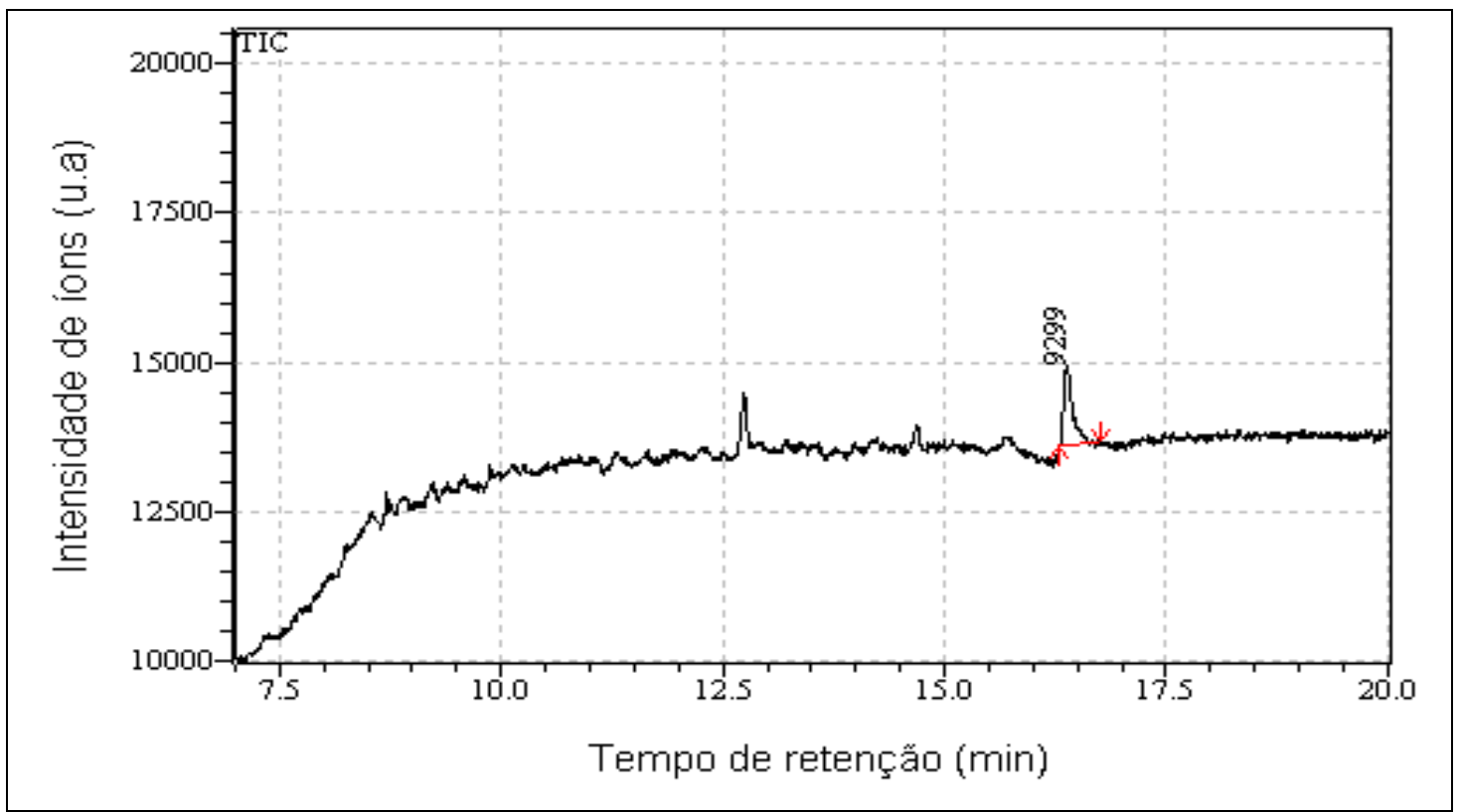

FIGURA 51 - Cromatograma da liberação de ácido oleico pelo dispositivo A1, no tempo $1 \mathrm{~h}-2^{\mathrm{a}}$ injeção 


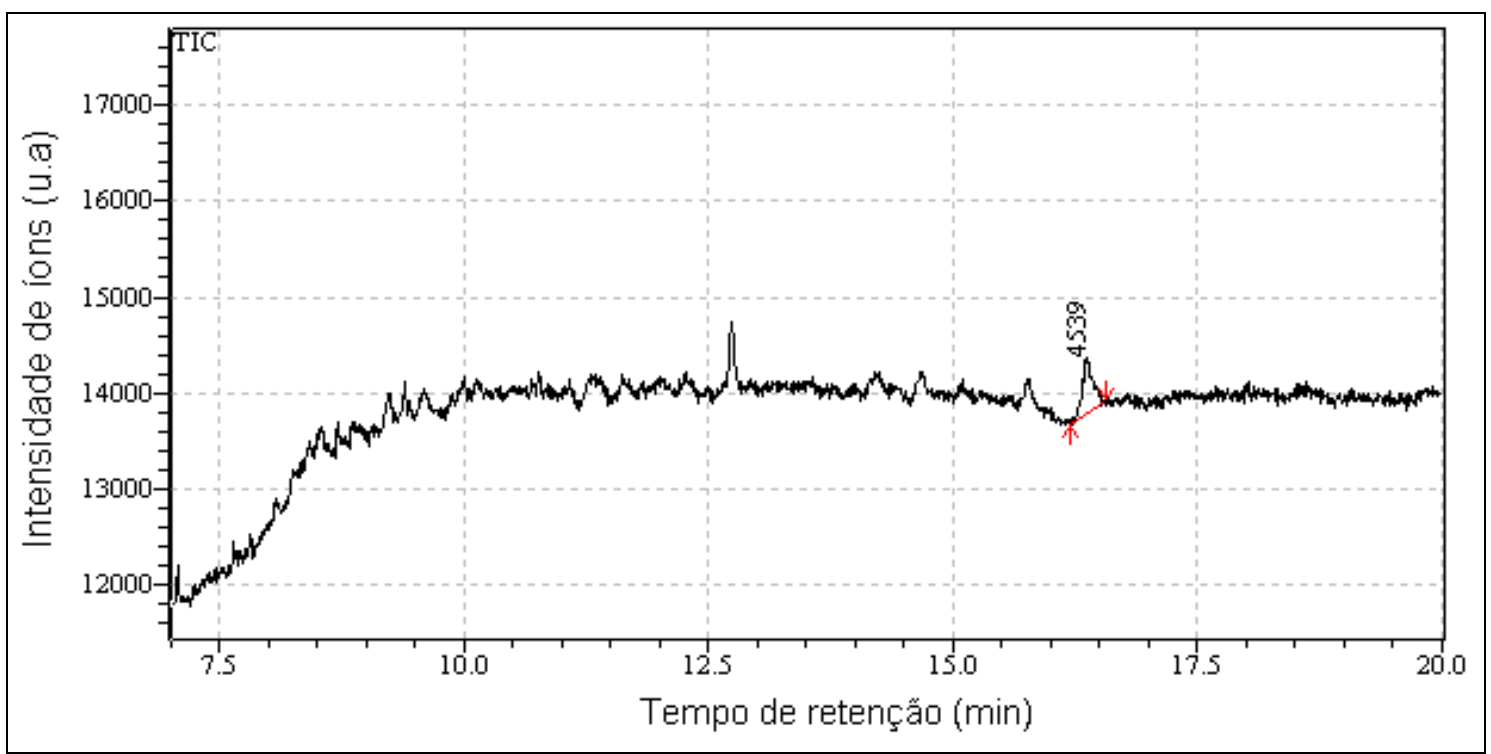

FIGURA 52 - Cromatograma da liberação de ácido oleico pelo dispositivo A1, no tempo $2 \mathrm{~h}-1^{\mathrm{a}}$ injeção

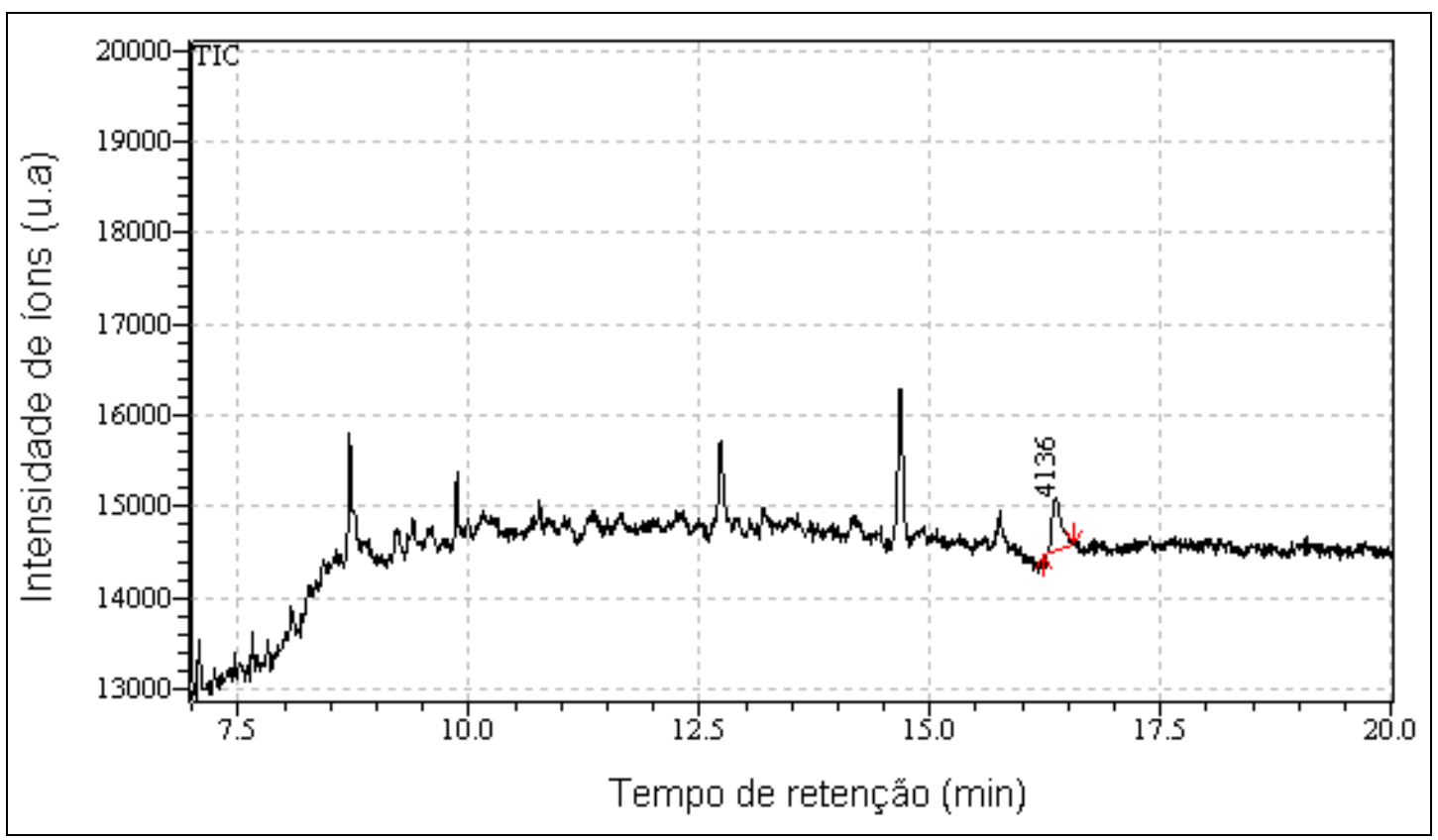

FIGURA 53 - Cromatograma da liberação de ácido oleico pelo dispositivo A1, no tempo $2 \mathrm{~h}-2^{\mathrm{a}}$ injeção 


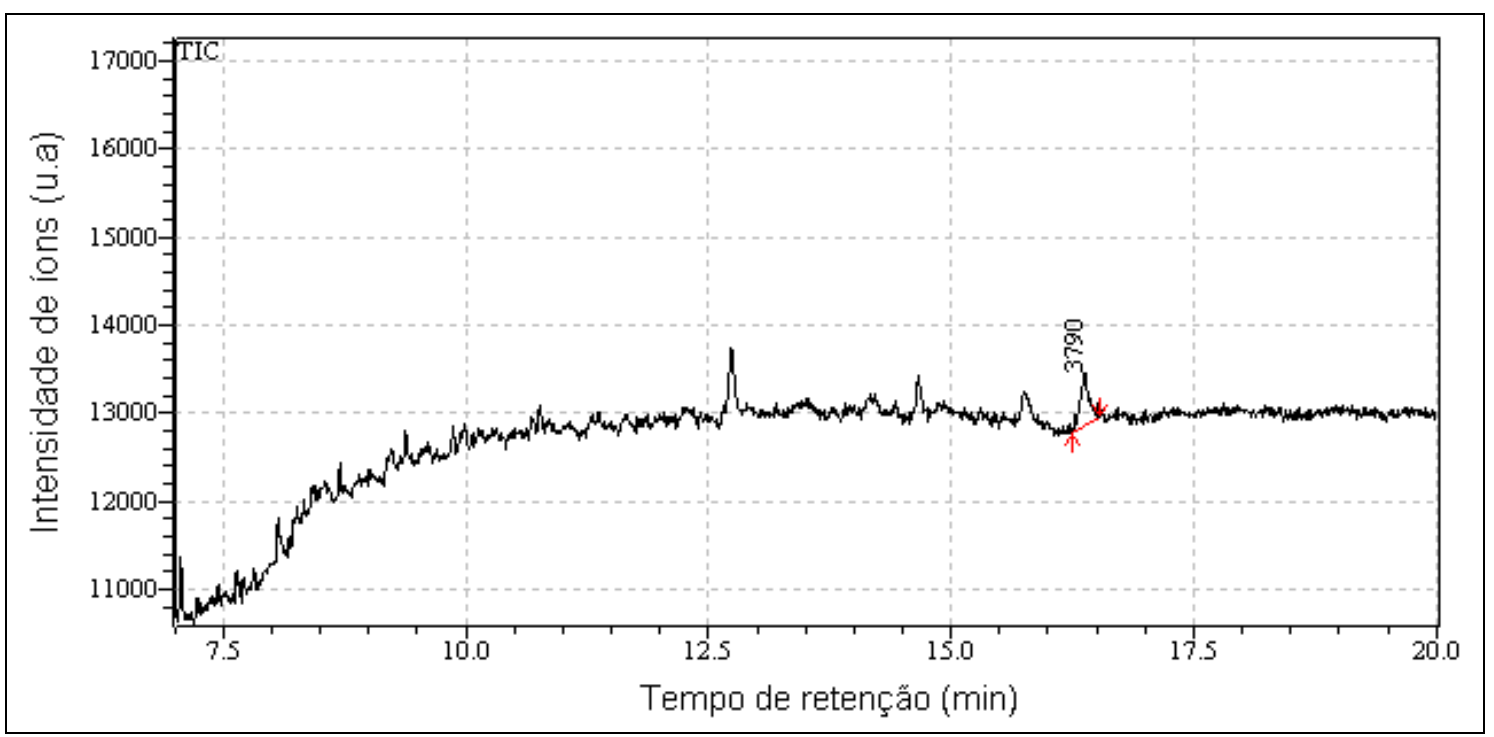

FIGURA 54 - Cromatograma da liberação de ácido oleico pelo dispositivo A1, no tempo $3 \mathrm{~h}-1^{\mathrm{a}}$ injeção

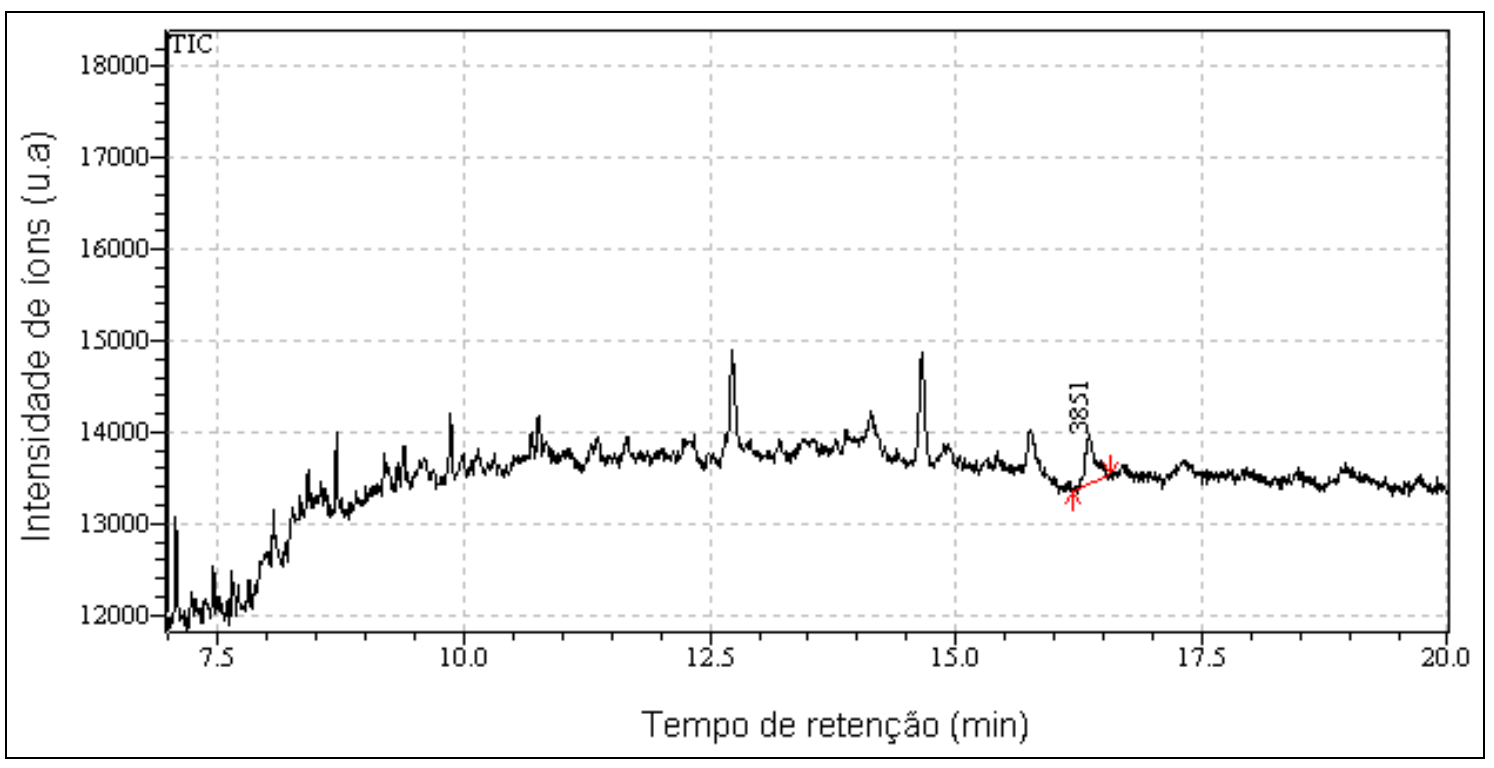

FIGURA 55 - Cromatograma da liberação de ácido oleico pelo dispositivo A1, no tempo $3 \mathrm{~h}-2^{\mathrm{a}}$ injeção 


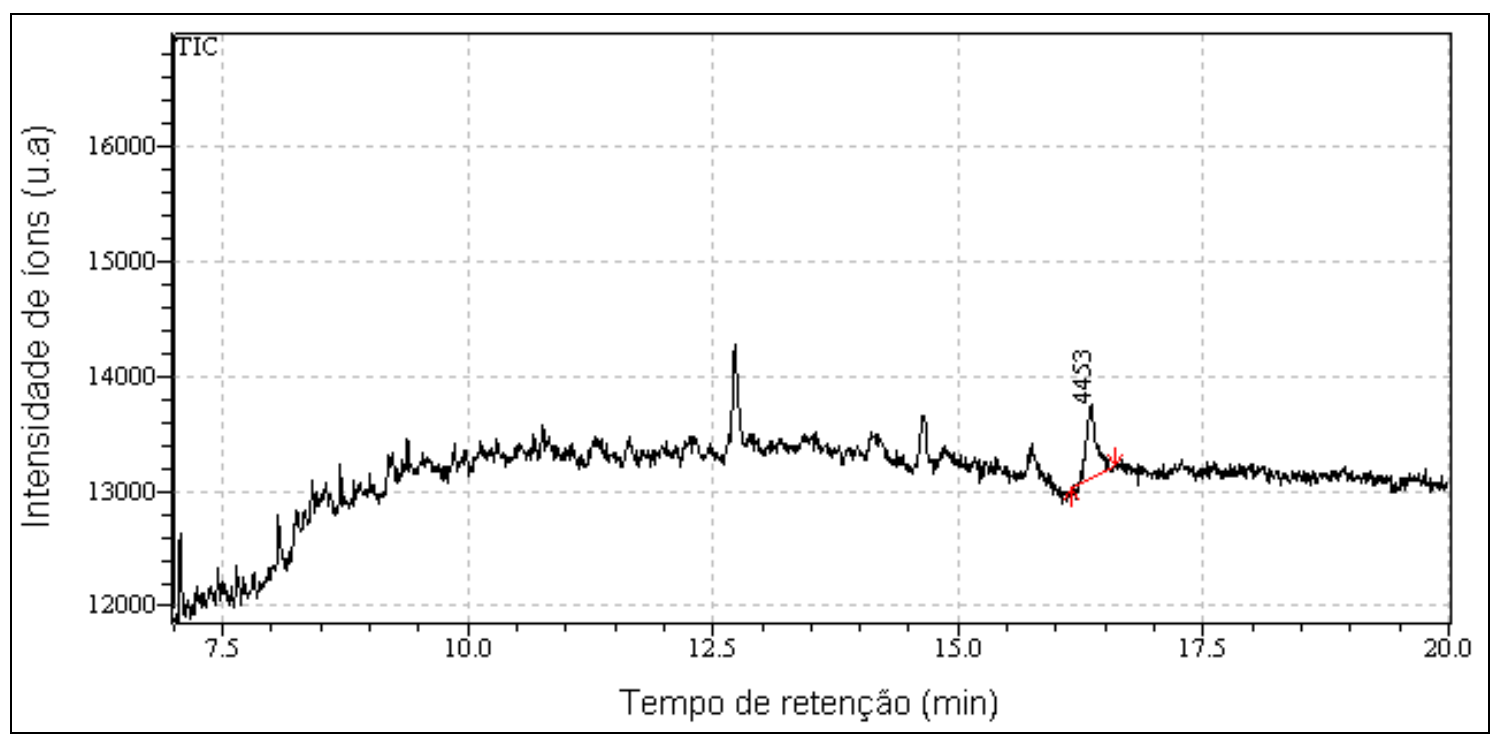

FIGURA 56 - Cromatograma da liberação de ácido oleico pelo dispositivo A1, no tempo $4 \mathrm{~h}-1^{\mathrm{a}}$ injeção

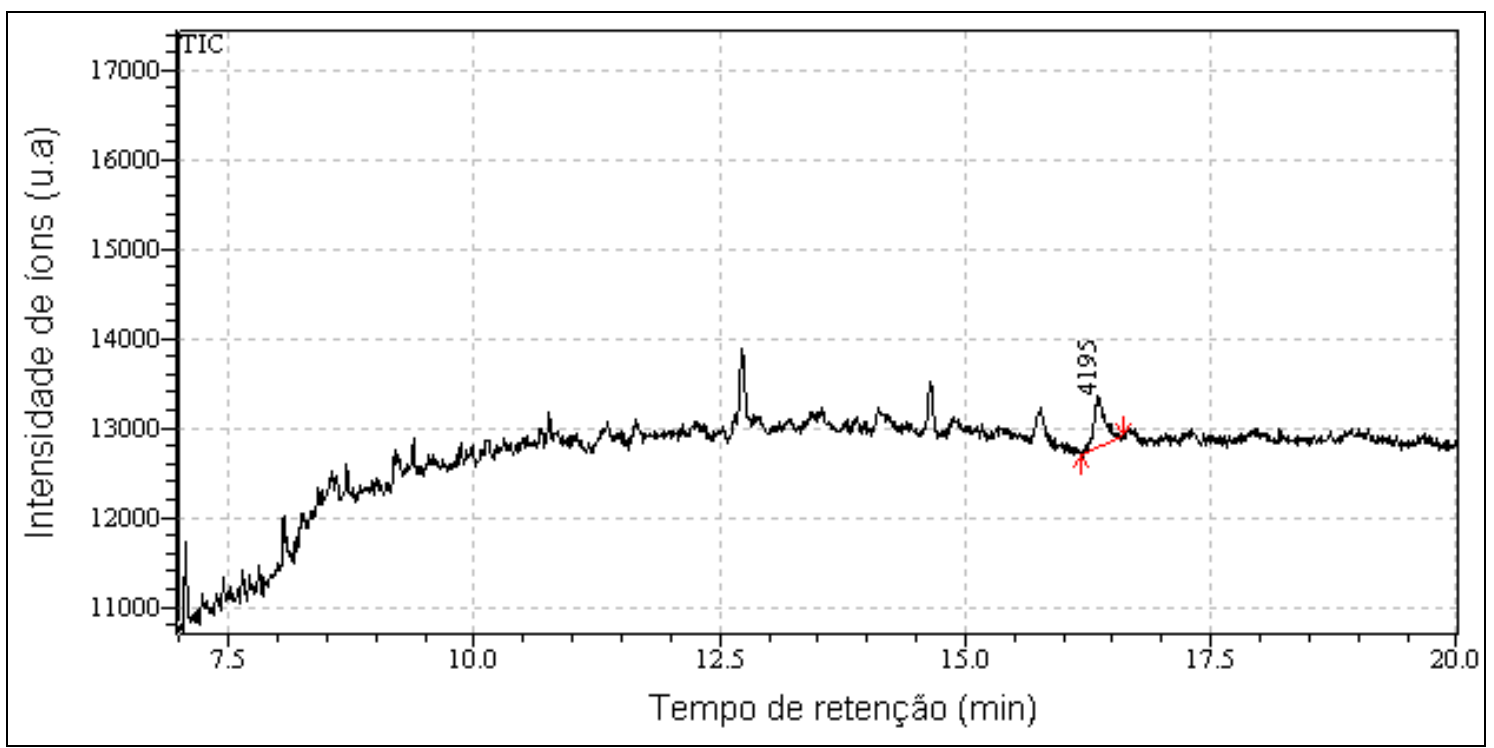

FIGURA 57 - Cromatograma da liberação de ácido oleico pelo dispositivo A1, no tempo $4 \mathrm{~h}-2^{\mathrm{a}}$ injeção 


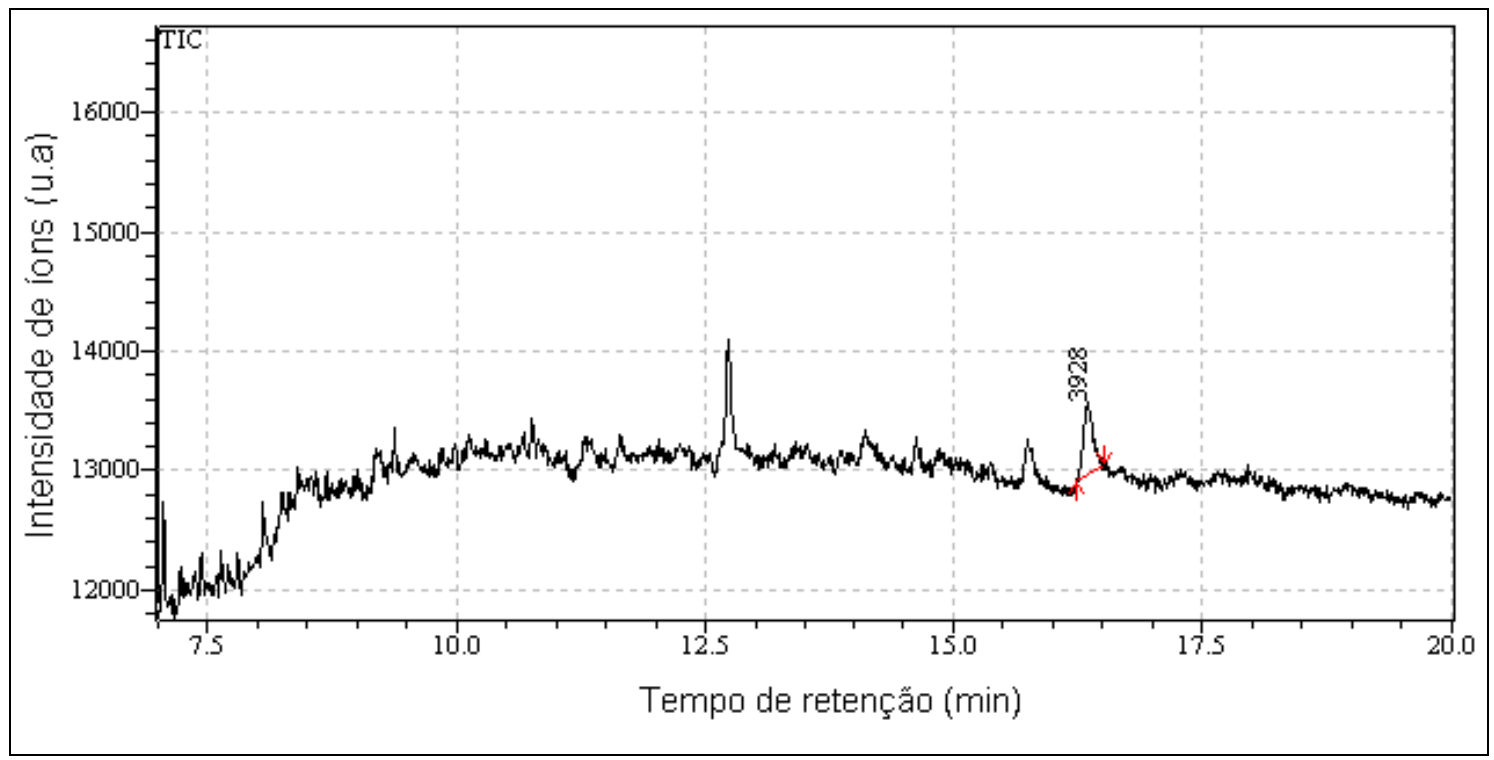

FIGURA 58 - Cromatograma da liberação de ácido oleico pelo dispositivo A1, no tempo $5 \mathrm{~h}-1^{\mathrm{a}}$ injeção

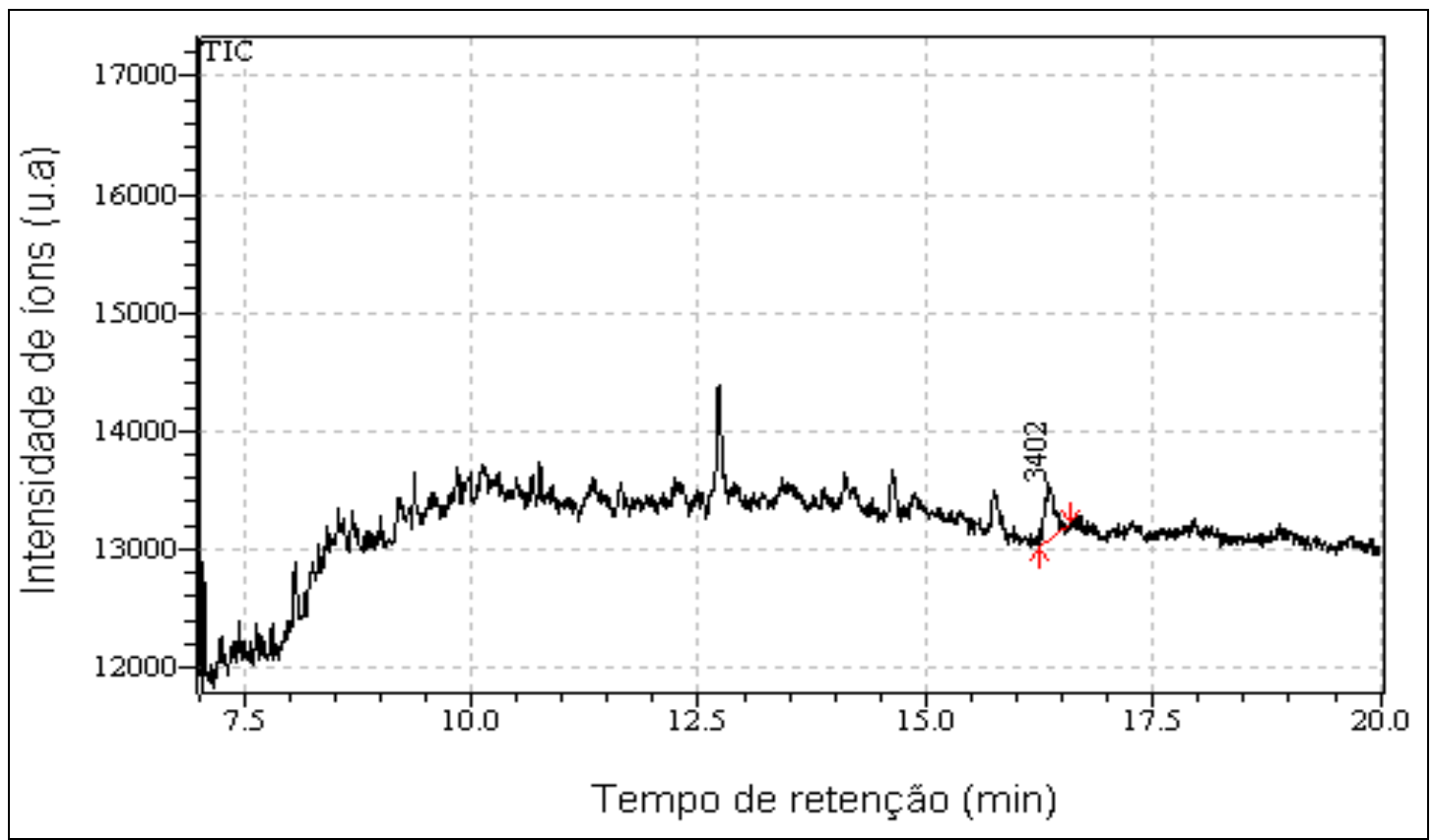

FIGURA 59 - Cromatograma da liberação de ácido oleico pelo dispositivo A1, no tempo $5 \mathrm{~h}-2^{\mathrm{a}}$ injeção 


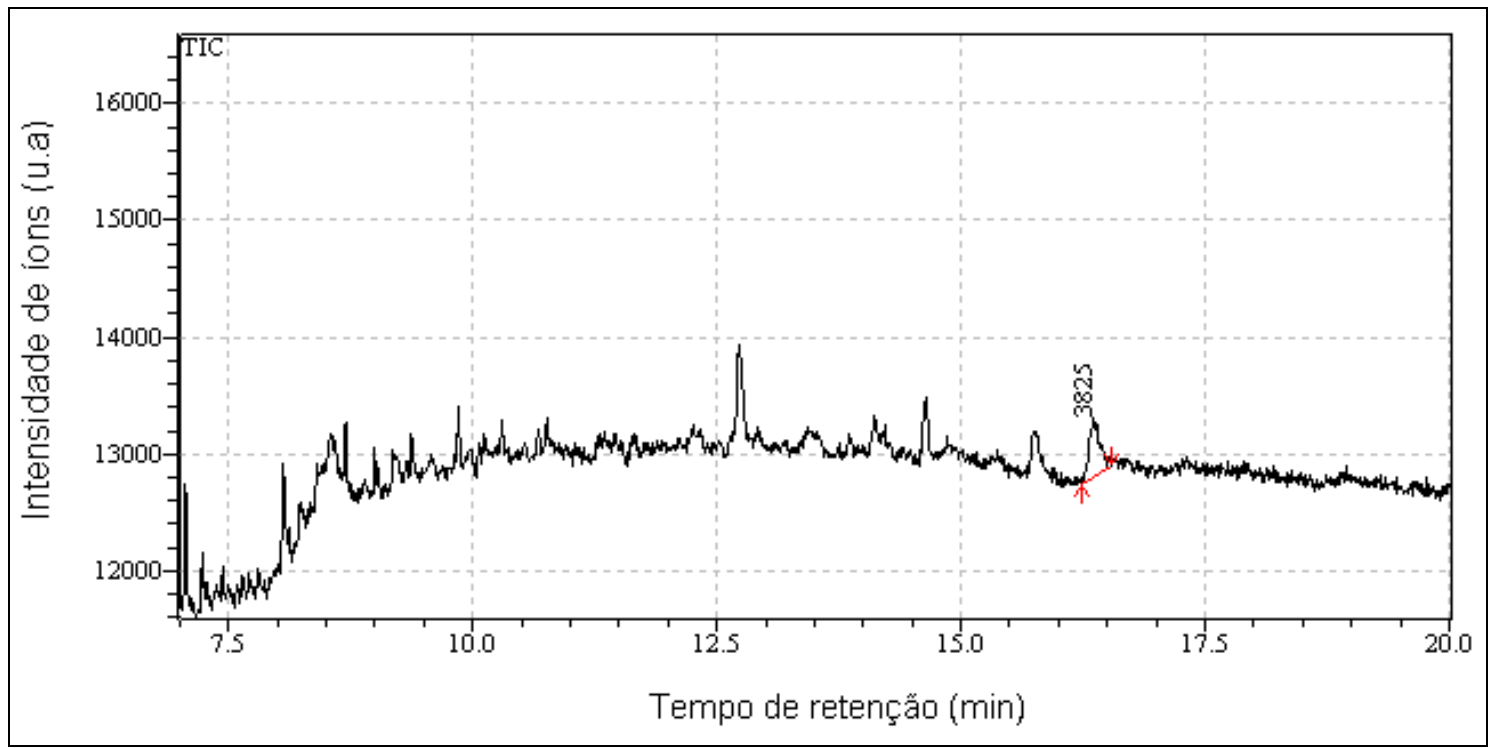

FIGURA 60 - Cromatograma da liberação de ácido oleico pelo dispositivo A1, no tempo $6 \mathrm{~h}-1^{\mathrm{a}}$ injeção

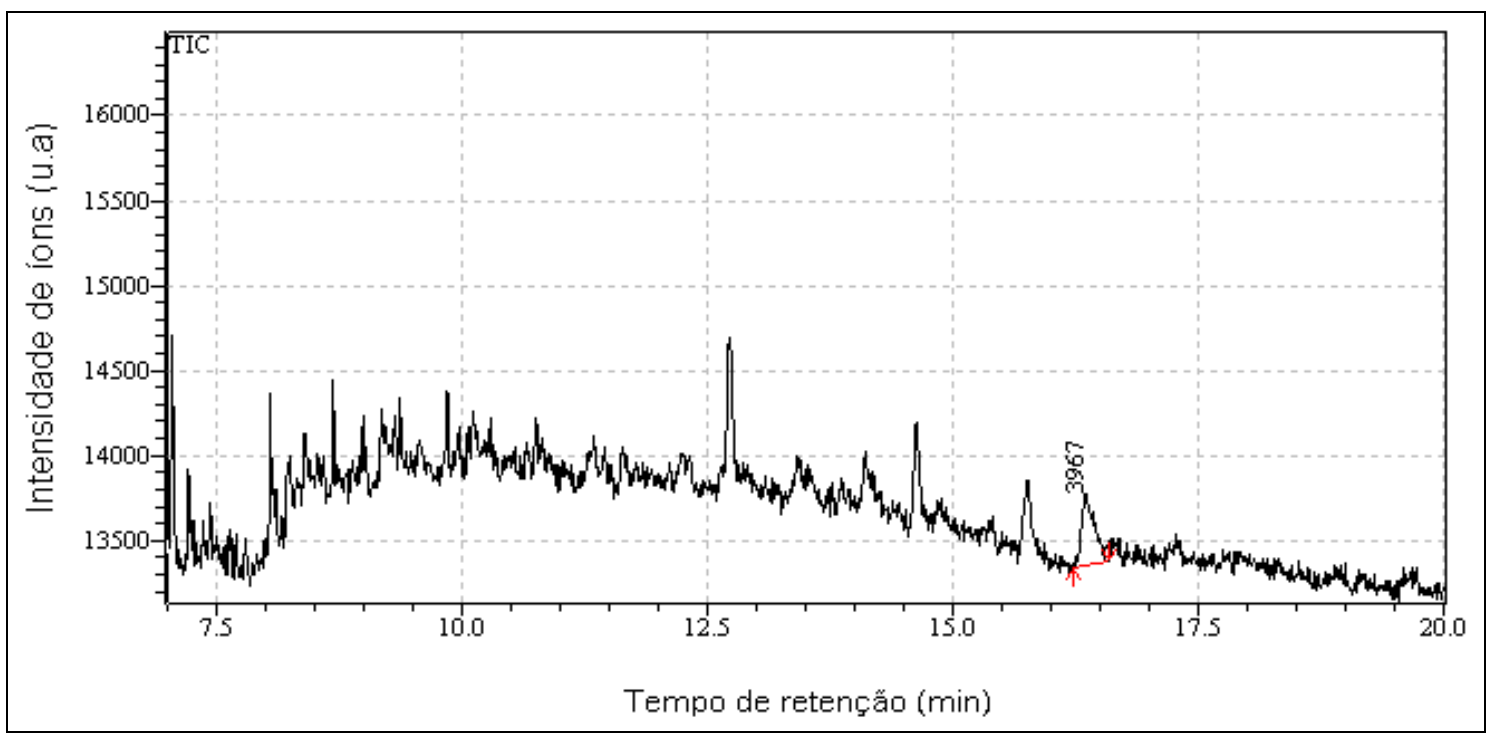

FIGURA 61 - Cromatograma da liberação de ácido oleico pelo dispositivo A1, no tempo $6 \mathrm{~h}-2^{\mathrm{a}}$ injeção 


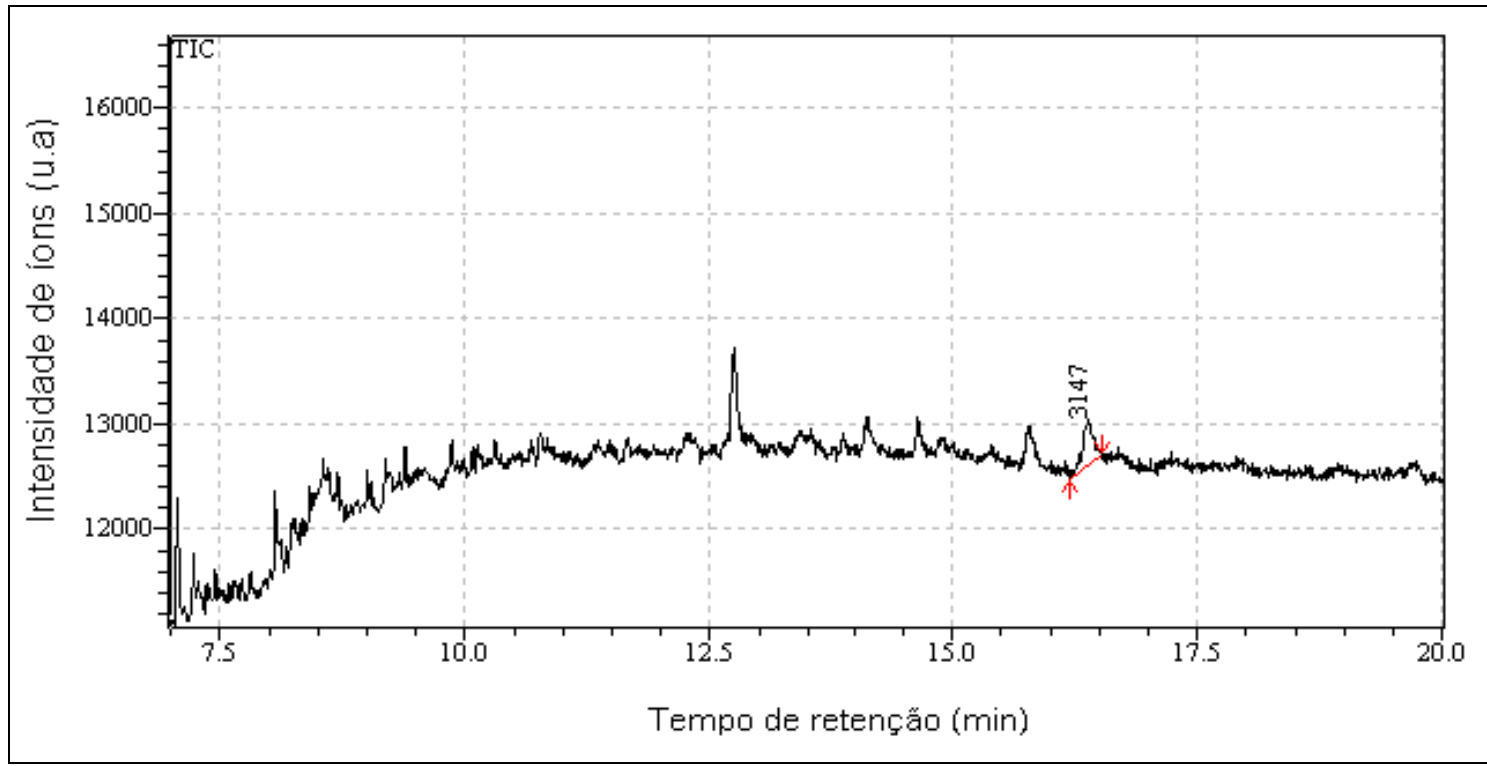

FIGURA 62 - Cromatograma da liberação de ácido oleico pelo dispositivo A1, no tempo $24 \mathrm{~h}-1^{\mathrm{a}}$ injeção

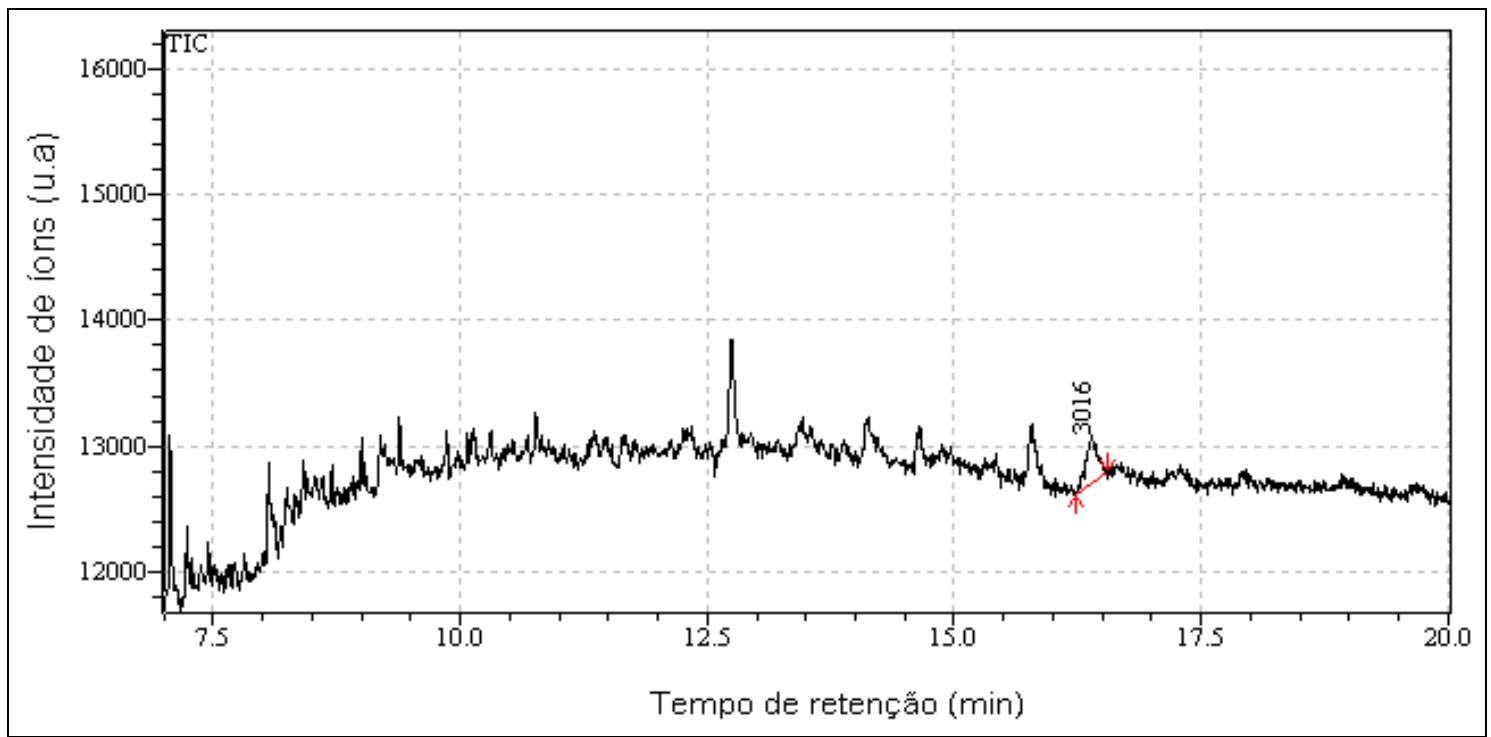

FIGURA 63 - Cromatograma da liberação de ácido oleico pelo dispositivo A1, no tempo $24 \mathrm{~h}-2^{\mathrm{a}}$ injeção 
APÊNDICE C - Cromatogramas da liberação de ácido oleico pelo dispositivo B1

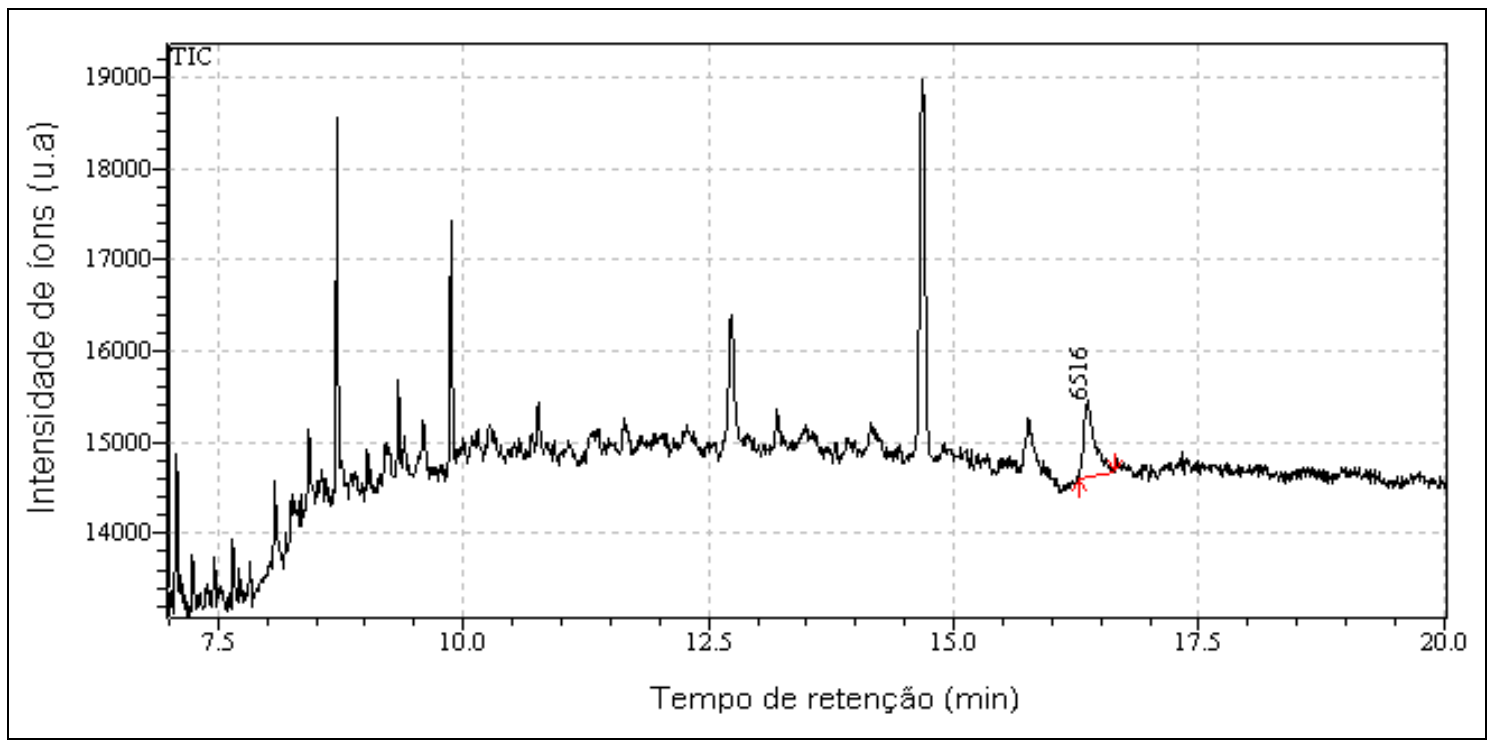

FIGURA 64 - Cromatograma da liberação de ácido oleico pelo dispositivo B1, no tempo $1 \mathrm{~h}-1^{\mathrm{a}}$ injeção

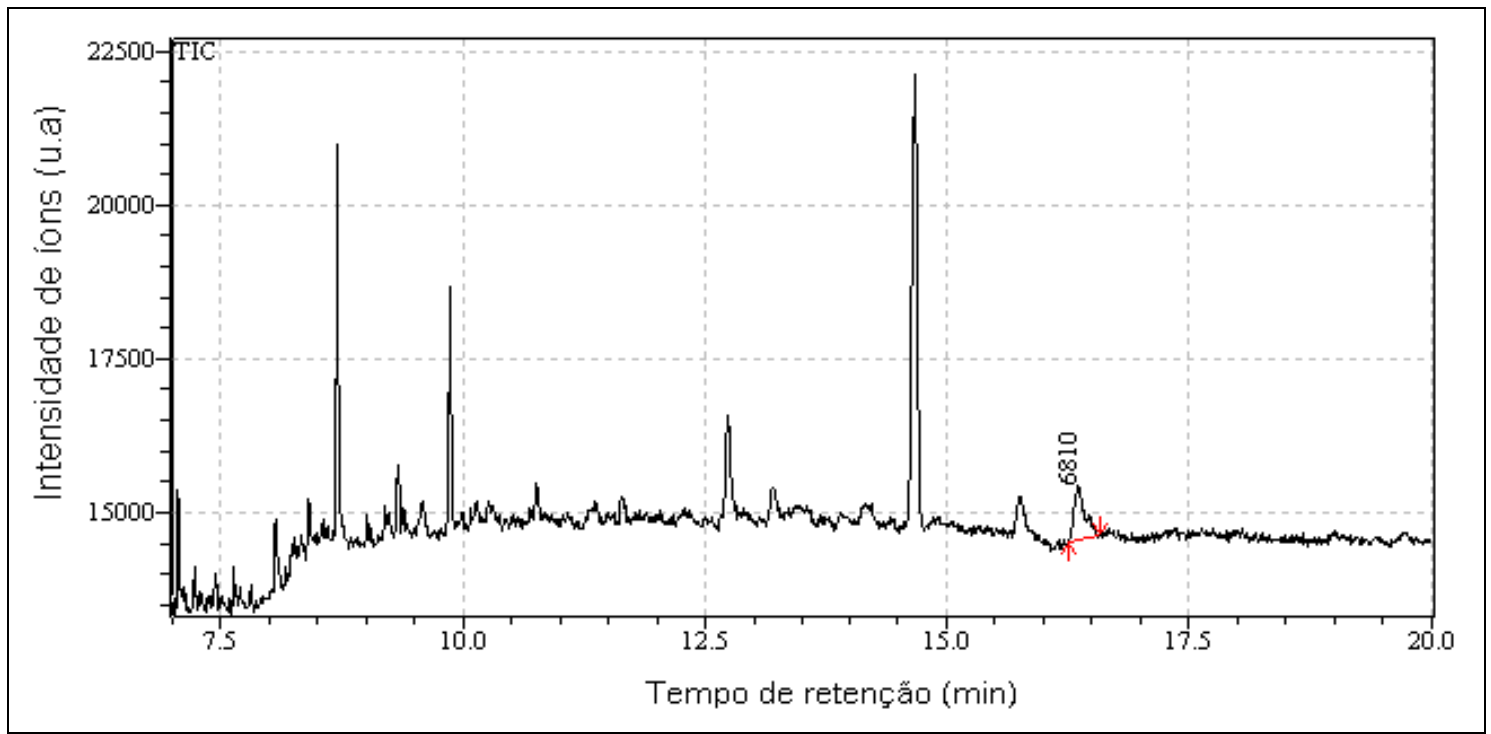

FIGURA 65 - Cromatograma da liberação de ácido oleico pelo dispositivo B1, no tempo $1 \mathrm{~h}-2^{\mathrm{a}}$ injeção 


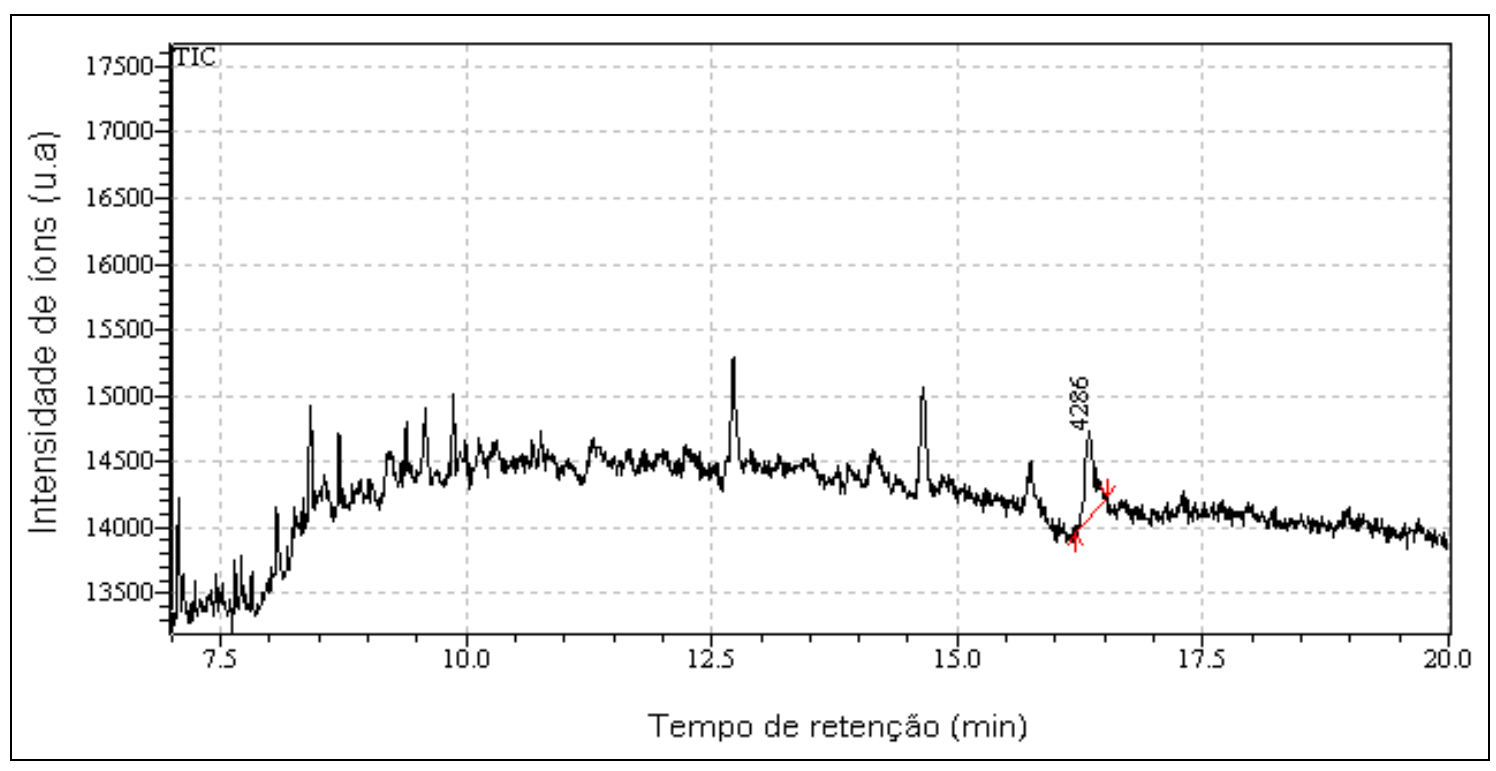

FIGURA 66 - Cromatograma da liberação de ácido oleico pelo dispositivo B1, no tempo $2 \mathrm{~h}-1^{\mathrm{a}}$ injeção

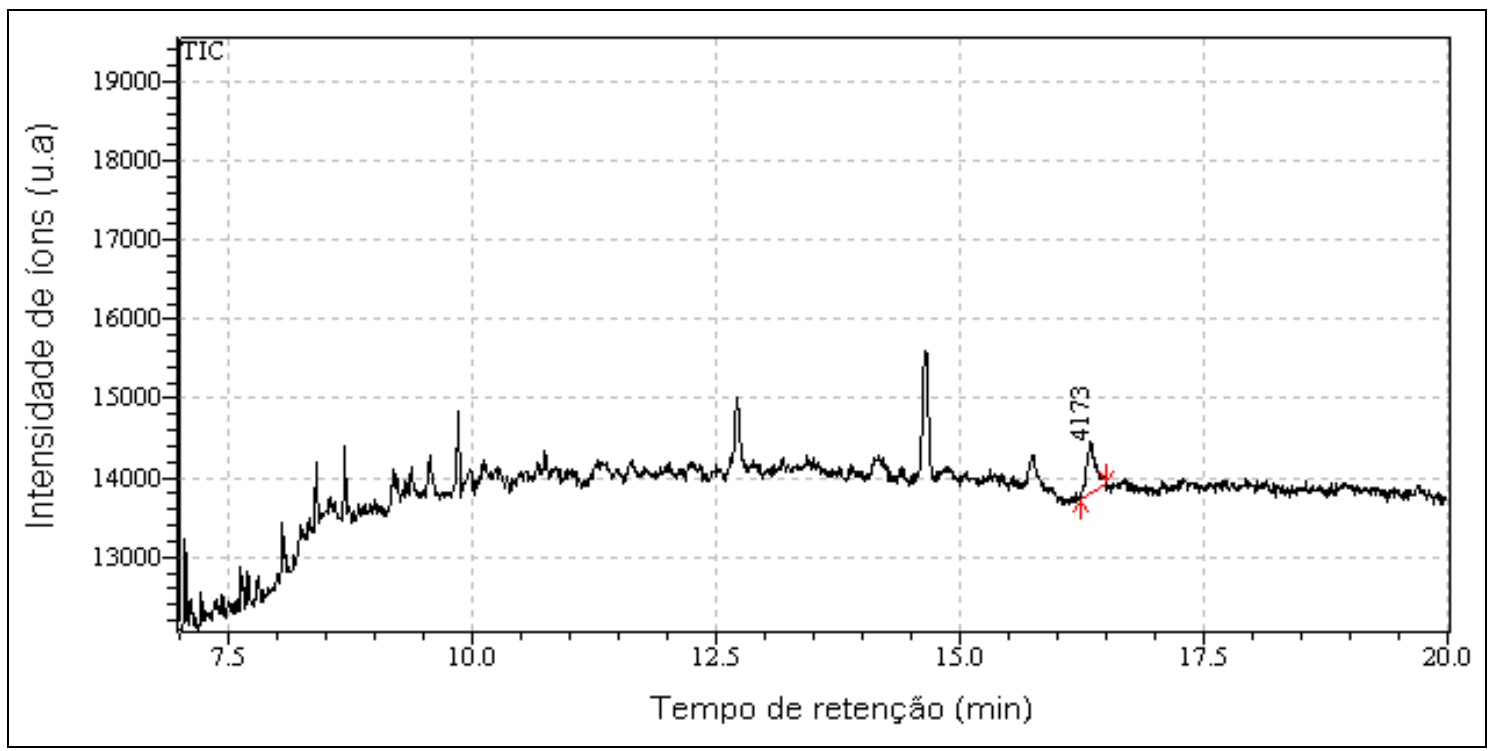

FIGURA 67 - Cromatograma da liberação de ácido oleico pelo dispositivo B1, no tempo $2 \mathrm{~h}-2^{\mathrm{a}}$ injeção 


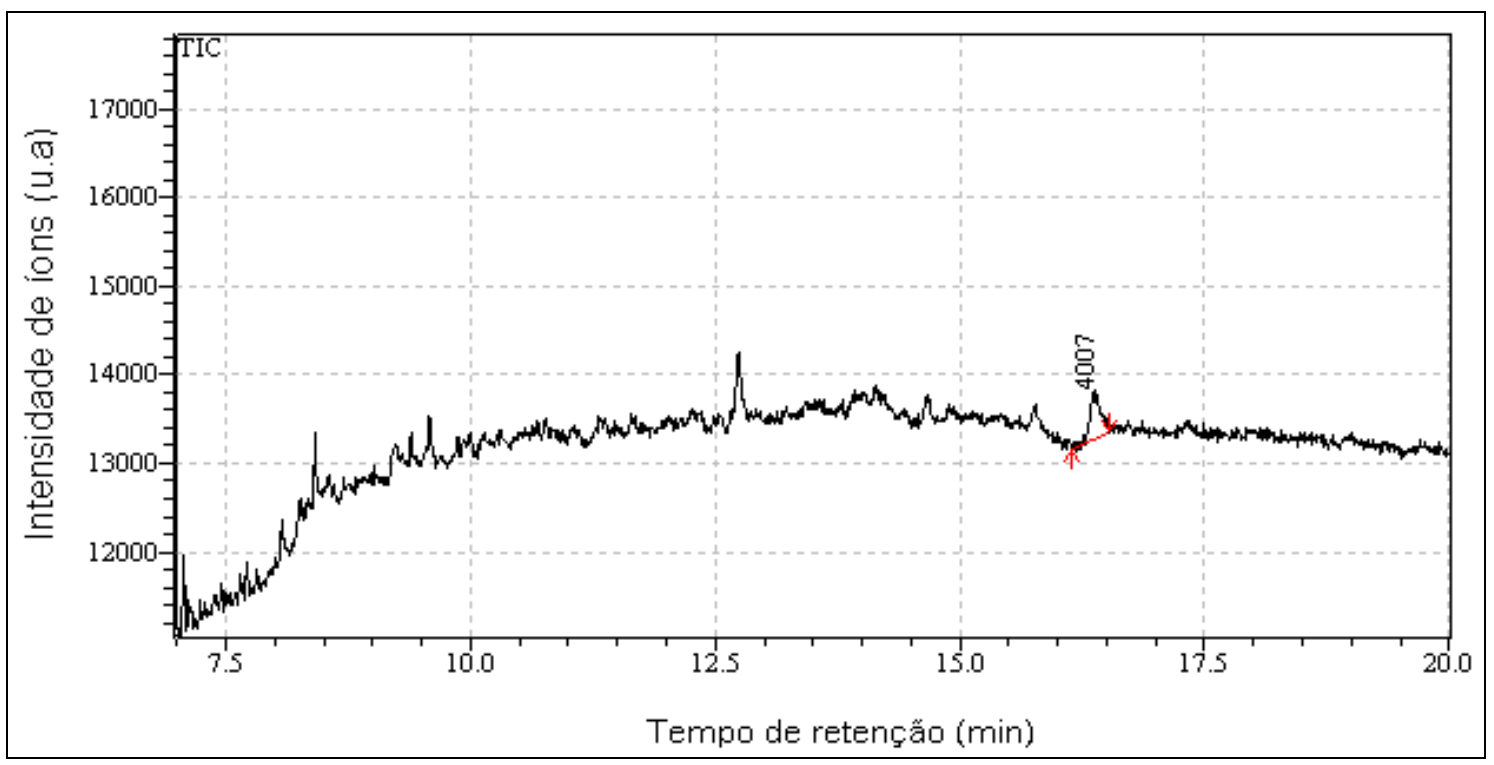

FIGURA 68 - Cromatograma da liberação de ácido oleico pelo dispositivo B1, no tempo $3 \mathrm{~h}-1^{\mathrm{a}}$ injeção

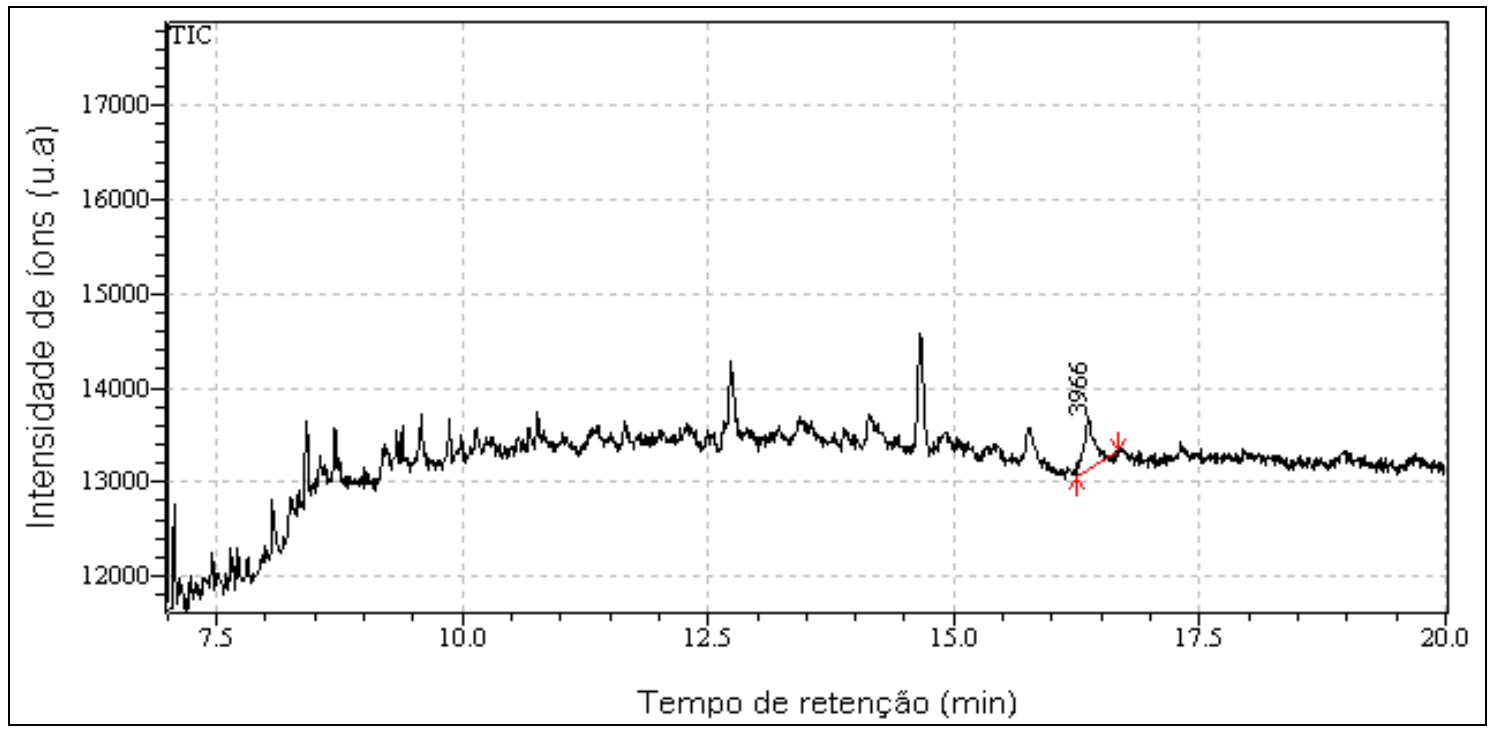

FIGURA 69 - Cromatograma da liberação de ácido oleico pelo dispositivo B1, no tempo $3 \mathrm{~h}-2^{\mathrm{a}}$ injeção 


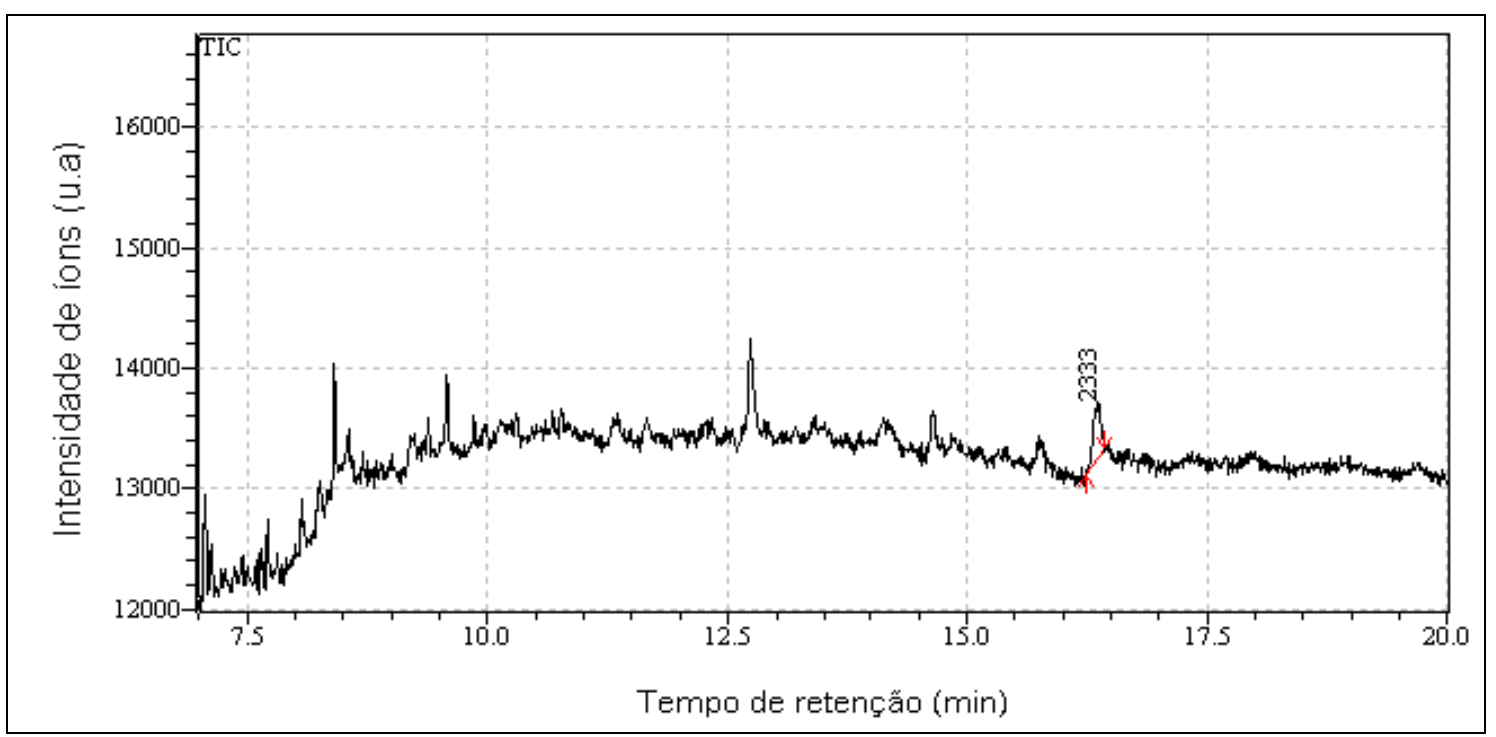

FIGURA 70 - Cromatograma da liberação de ácido oleico pelo dispositivo B1, no tempo $4 \mathrm{~h}-1^{\mathrm{a}}$ injeção

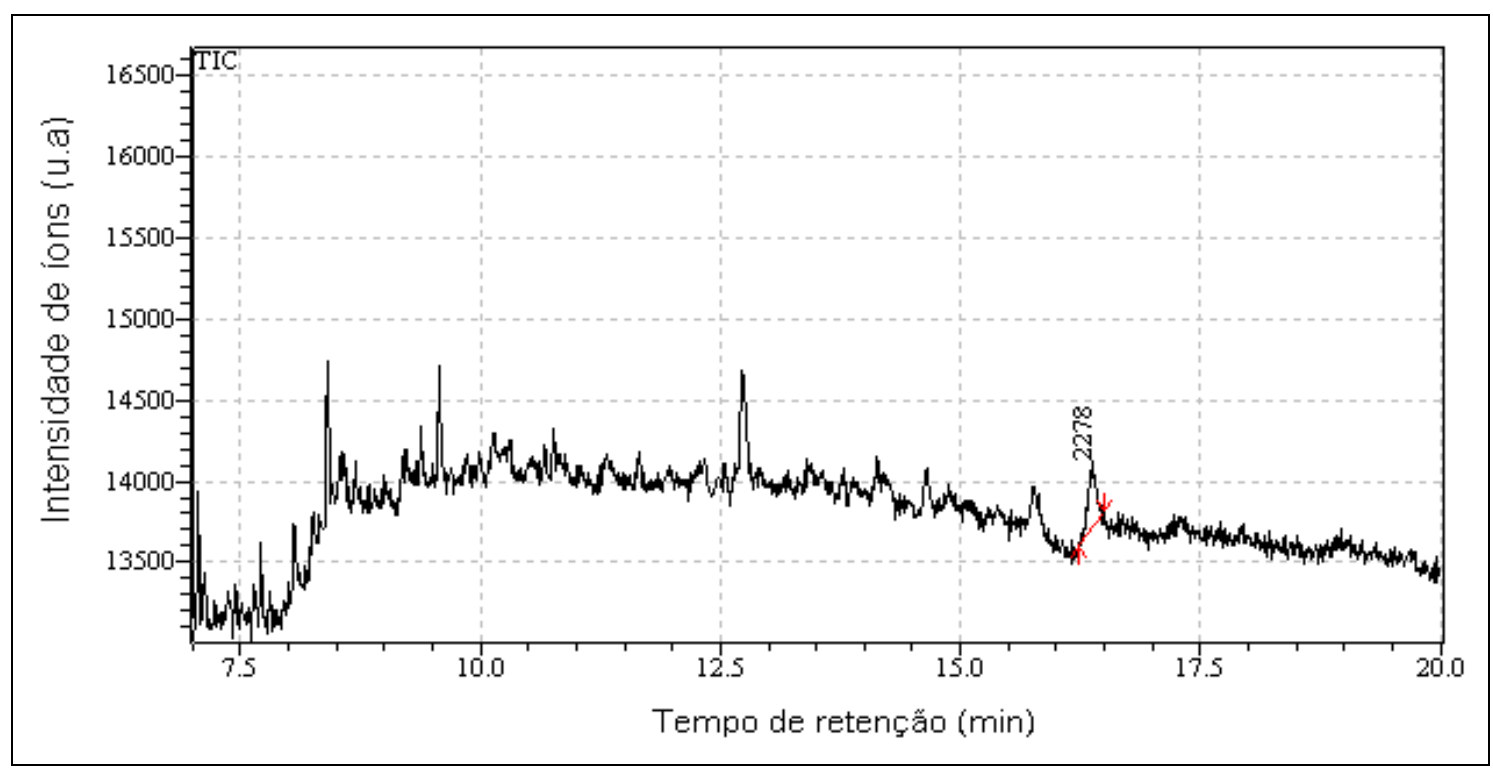

FIGURA 71 - Cromatograma da liberação de ácido oleico pelo dispositivo B1, no tempo $4 \mathrm{~h}-2^{\mathrm{a}}$ injeção 


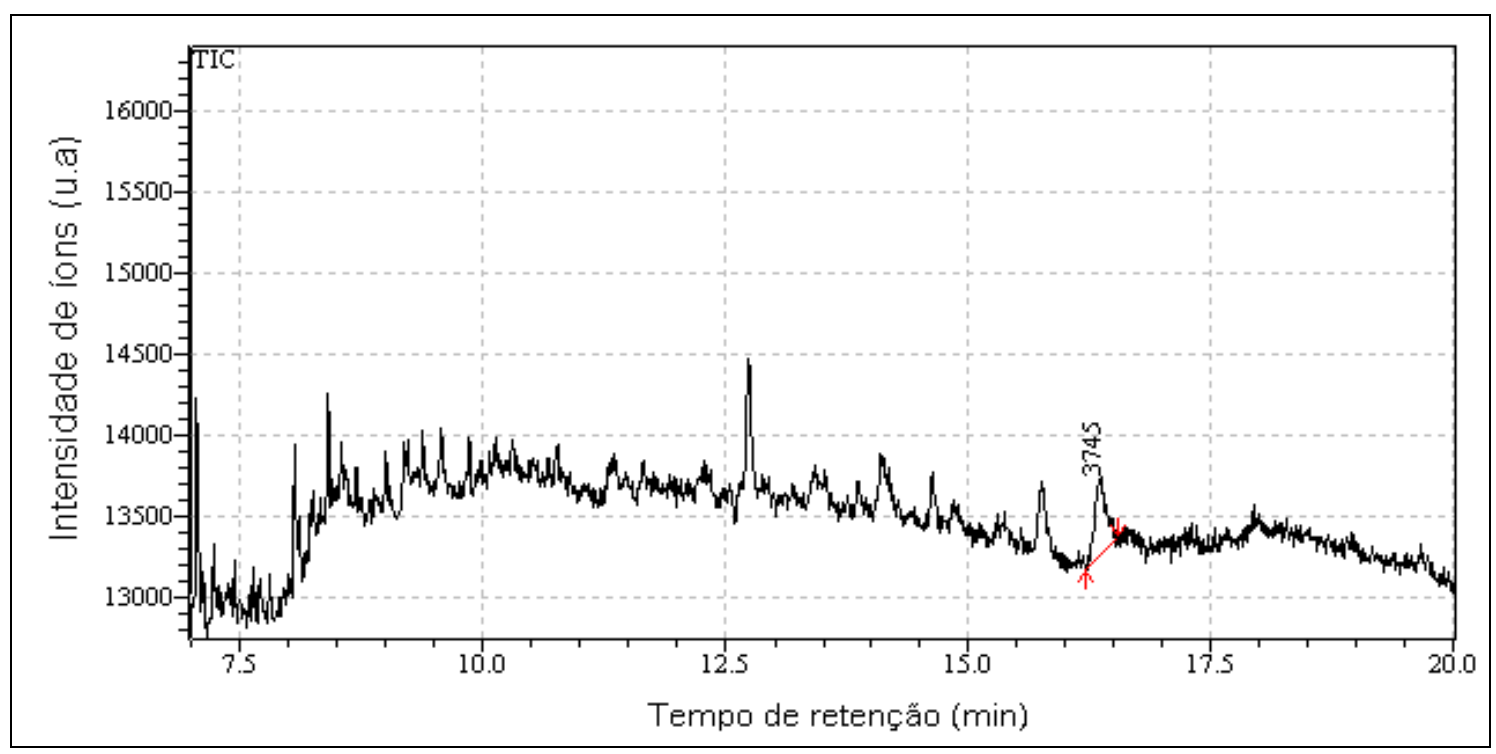

FIGURA 72 - Cromatograma da liberação de ácido oleico pelo dispositivo B1, no tempo $5 \mathrm{~h}-1^{\mathrm{a}}$ injeção

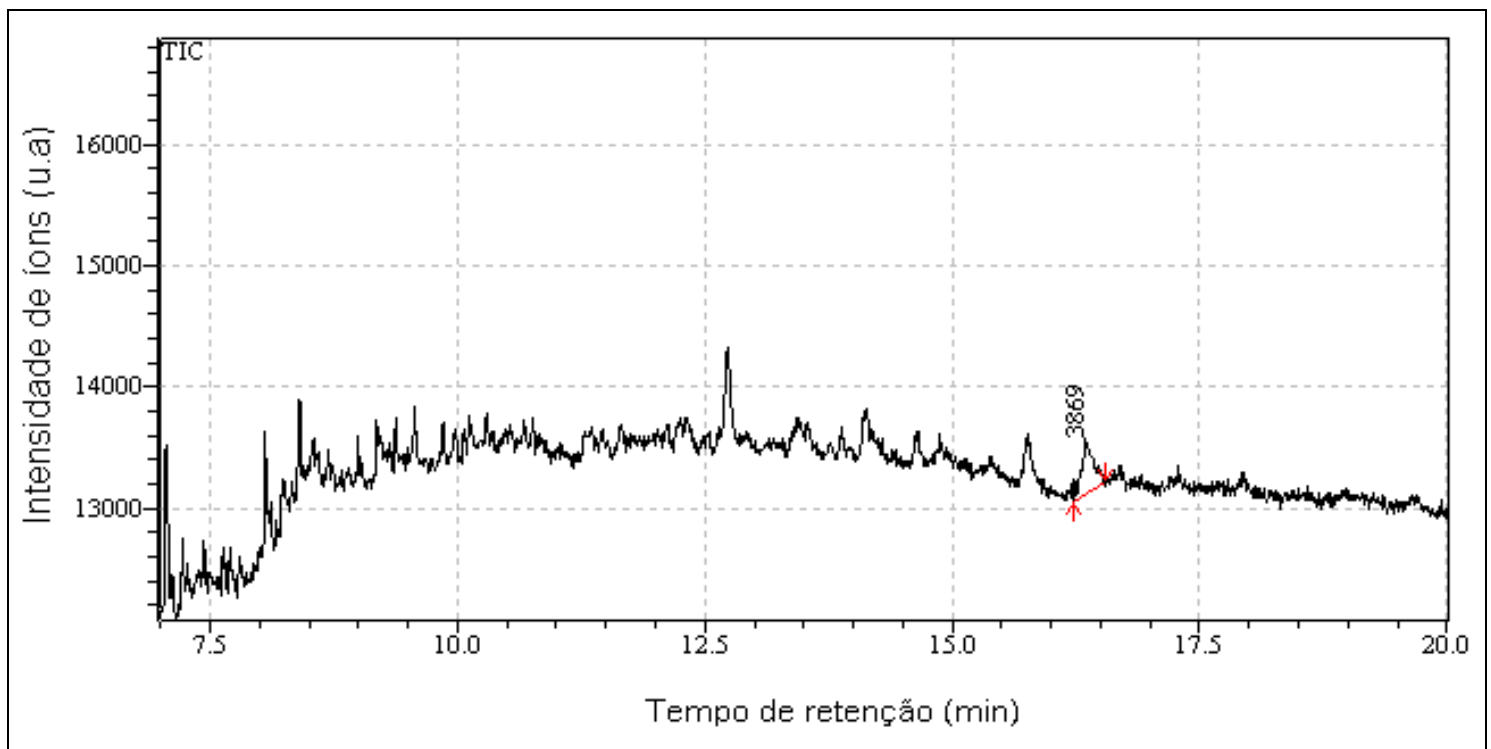

FIGURA 73 - Cromatograma da liberação de ácido oleico pelo dispositivo B1, no tempo $5 \mathrm{~h}-2^{\mathrm{a}}$ injeção 


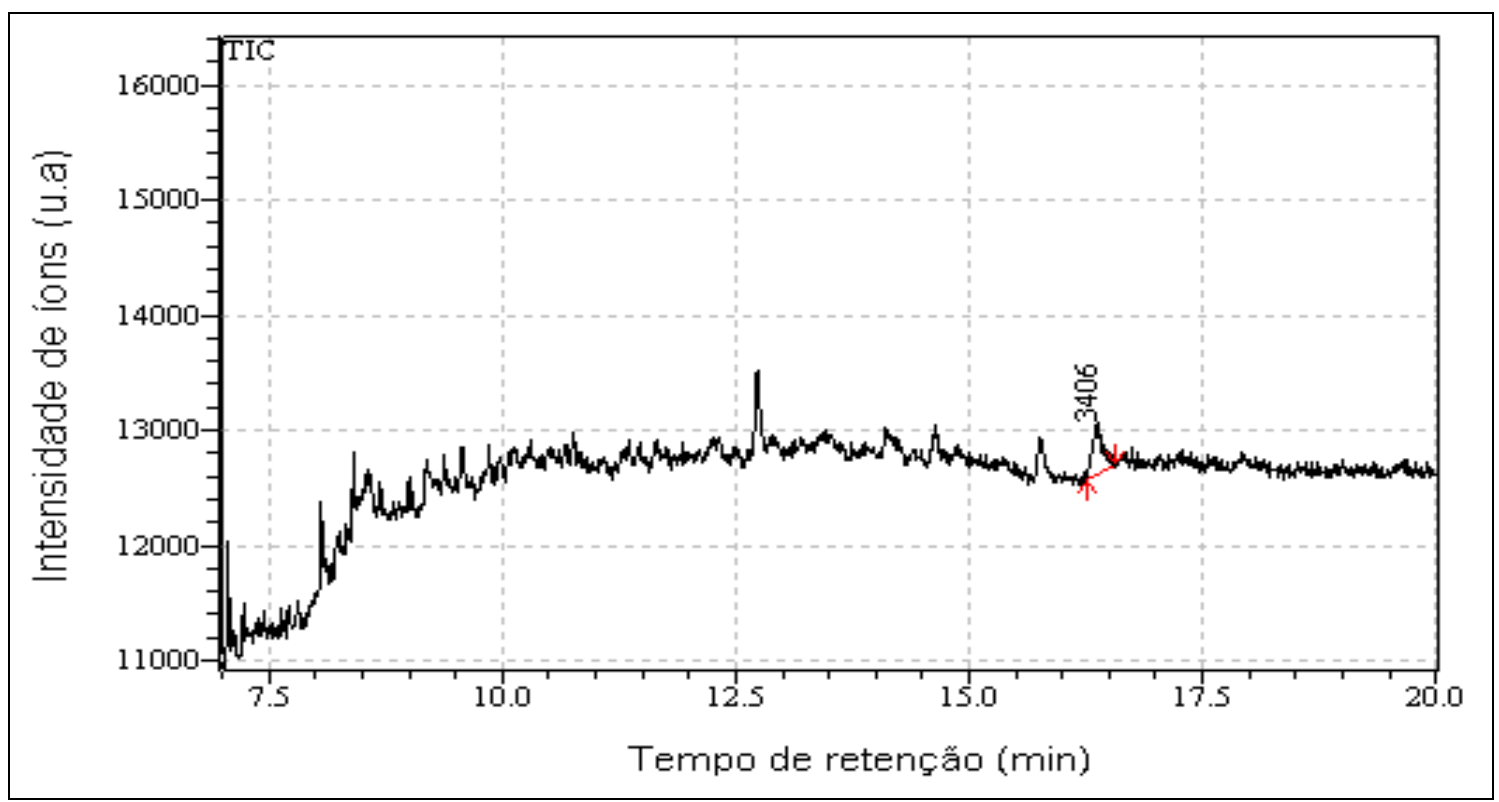

FIGURA 74 - Cromatograma da liberação de ácido oleico pelo dispositivo B1, no tempo $6 \mathrm{~h}-1^{\mathrm{a}}$ injeção

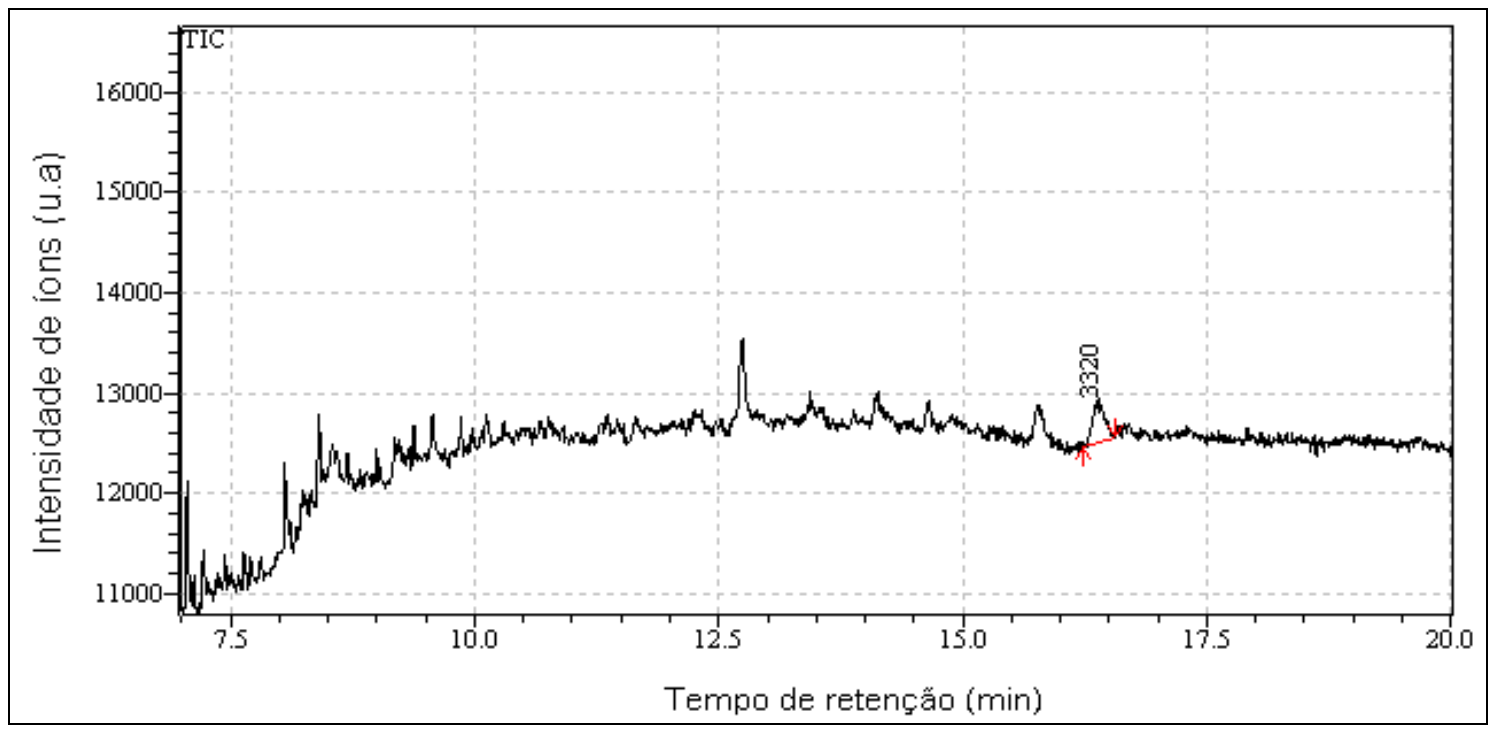

FIGURA 75 - Cromatograma da liberação de ácido oleico pelo dispositivo B1, no tempo $6 \mathrm{~h}-2^{\mathrm{a}}$ injeção 


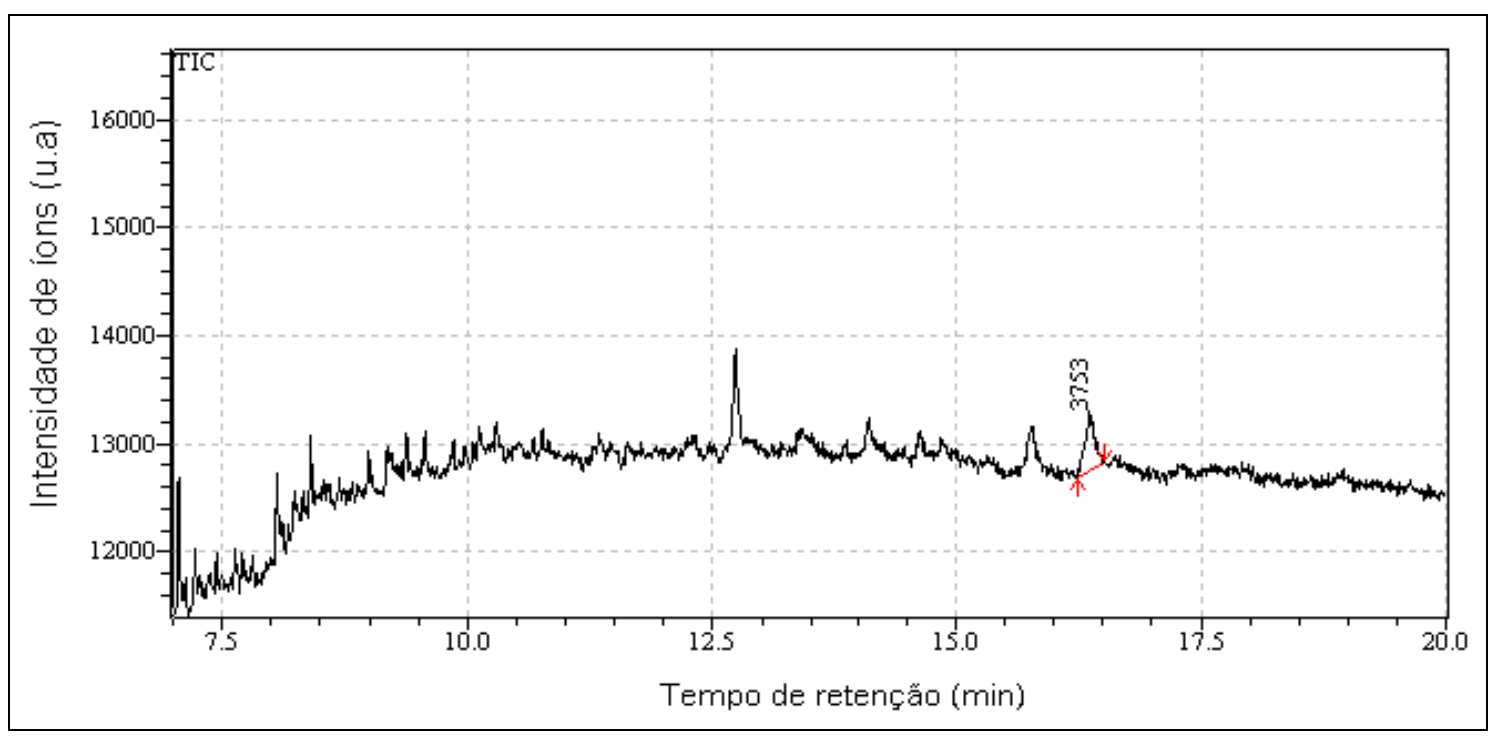

FIGURA 76 - Cromatograma da liberação de ácido oleico pelo dispositivo B1, no tempo $24 \mathrm{~h}-1^{\mathrm{a}}$ injeção

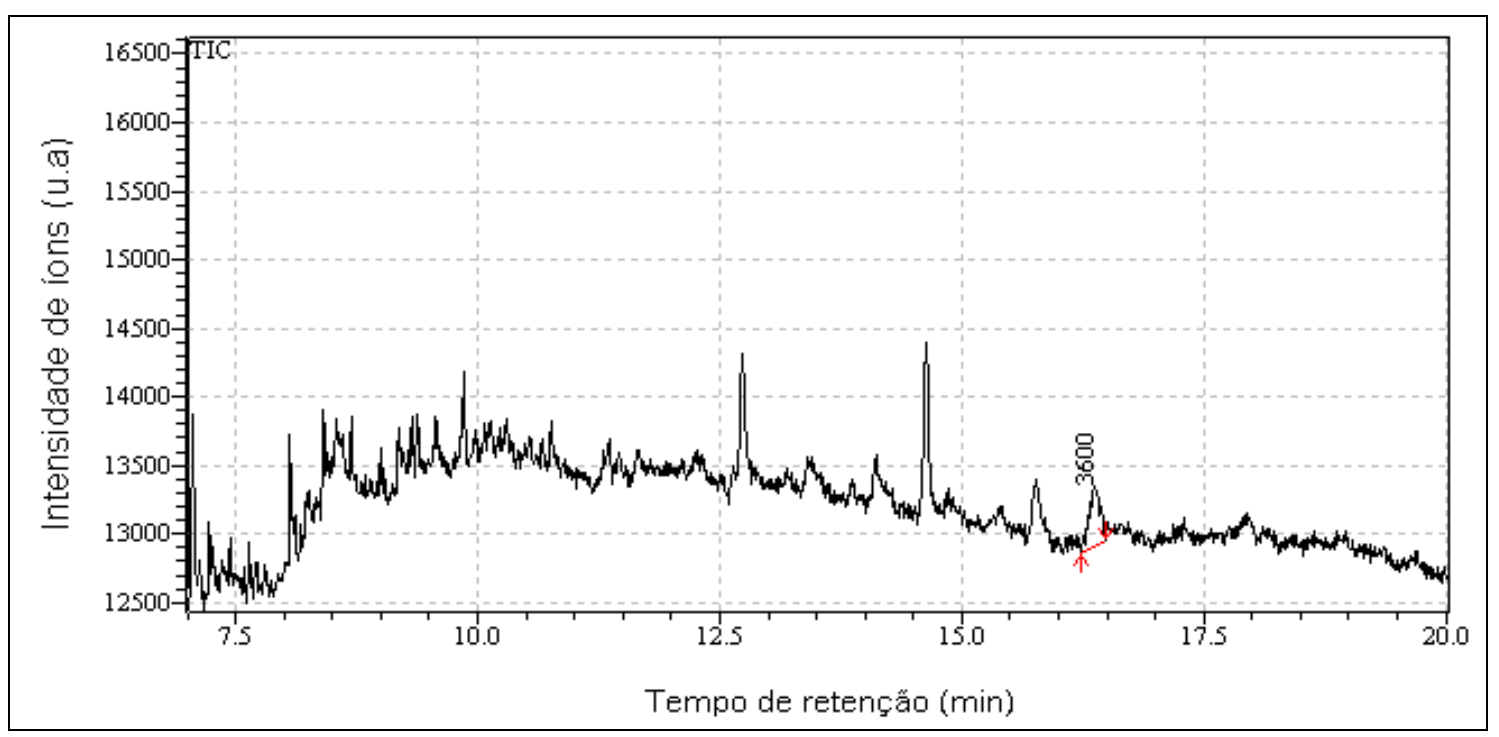

FIGURA 77 - Cromatograma da liberação de ácido oleico pelo dispositivo B1, no tempo $24 \mathrm{~h}-2^{\mathrm{a}}$ injeção 


\section{REFERÊNCIAS}

1. A PELE e o sentido do tato. Disponível em: http://www.afh.bio.br/sentidos/img/sentidos\%20pele.jpg. Acesso em: 24/06/2009.

2. ABAD, L. V.; RelleVE, L. S.; ARANILLA, C. T.; DELA ROSA, A. M. Properties of radiation synthesized PVP-kappa carragenan hydrogel blens. Radiation Physics and Chemistry. n. 68, 2003. P. 901-908.

3. AÇAí (Euterpe oleracea Mart.). Disponível em: http://www.iac.sp.gov.br ICentros/Fruticultura/FRUTIFERAS/Imagens/acai.jpg. Acesso em 25/01/2009.

4. AJJI, Z., OTHMAN, I., ROSIAK, J.M. Production of hydrogel wound dressings using gamma radiation. Nucl. Instrum. Methods Phys. Res., v. 229, 2005. p. $375-380$.

5. ALENCASTRE, J.B.; BENTLEY, M.V.L.B.; GARCIA, F.S.; MORAGAS,M. de; VILADOT, J.L.; MARCHETTI, J.M. Estudo das características e propriedades da permeação in vitro de micropartículas de CMC/Quitosana como sistema de liberação cutânea de vitamina E. Rev. Bras. Cienc. Farm. V. 42, n. 1. 2006.

6. ALLEN JÚNIOR, L. V.; POPOVICH, N. G.; ANSEL, H. C. Formas farmacêuticas e sistemas de liberação de fármacos. 8 ed. Porto Alegre: Artmed, 2007. Cap. 4, 5 e 11. 775 p.

7. AMARAL, R. H. Estudo da incorporação e liberação de um extrato de algas vermelhas em membranas de hidrogel. 2009. Dissertação (Mestrado) - Instituto de Pesquisas Energéticas e Nucleares, São Paulo.

8. AMERICAN SOCIETY FOR TESTING AND MATERIALS. Standard test methods for determination of gel content and swell ratio of crosslinked ethylene plastics, 2001 (ASTM D 2765 - 01)

9. AMERICAN SOCIETY FOR TESTING AND MATERIALS. Test method of test for water absorption of plastics, 1998 (ASTM D 570).

10. AMERICAN SOCIETY FOR TESTING AND MATERIALS. Standard practice for testing biomaterials in rabbits for primary skin irritation, 1996 (ASTM F719).

11. ANALISADORES de massas quadrupolos. Disponível em: http://www.espectrometriademassas.com.br/capitulos/assuntos/assunt o.asp?codcapitulo $=8 \&$ codassunto $=17$ \&numero $=3$. Acesso em 20/04/2010. 
12. AUTIAN, J. Toxicological evaluation of biomaterials: primary acute toxicity screening program. Artificial Organs. v. 1, n. 1, 1977. P. 53-60.

13. BARABAS, E.S. N-vinyl amide polymers. In: MARK; BIKALES; OVERBERGER; MENGES. Encyclopedia of polymers science and engineering. New York: Wilei Interscience, v.17, 1989. p. 167-198.

14. BARATA, E.A.F. A Cosmetologia - Princípios Básicos. São Paulo: Tecnopress, 2003.

15. BARRY, B. Liberação transdérmica de fármacos. In: AULTON, M.E. Delineamento de formas farmacêuticas. 2. ed. São Paulo: Artmed, 2005. Cap. 33, p. 504-536.

16. BAUMANN, L. Dermatologia Cosmética: Princípios e prática. Rio de Janeiro: Revinter, 2004.

17. BERACA SABARÁ. Óleo de acai refinado - Rain Forest RF4410. Informe técnico. 2007.

18. BEVARESCO, V. P.; MACHADO, L. D. B.; ZAVAGLIA, C. A. C.; REIS, M. C. Caracterização mecânica de hidrogéis de PVAl para serem utilizados como cartilagem articular artificial reticulados por radiação. Rev. Bras. Pesq. Des. v. 4, n. 3, 2002. P. $1679-1681$.

19. BOBBIO, F. O.; DRUZIAN, J. I.; ABRÃO, P. A.; BOBBIO, P. A.; FADELLI, S. Identificação e quantificação das antocianinas do fruto do açaizeiro (Euterpe oleracea) Mart. Ciênc. Tecnol. Aliment. Campinas, v. 20, n.3, 2000;

20. CARVALHO, R.A., GROSSO, C.R.F. Efeito do tratamento térmico e enzimático nas propriedades de filmes de gelatina. Ciênc. Tecnol. Aliment. Campinas, v. 26, n.3, 2006. p. 495-501;

21. CHARLESBY, A. Radiation Chemistry of Polymers. In: FARHATAZIZ; RODGERS, M. A. J. (eds.). Radiation Chemistry: principles and applications. New York: VCH Publishers, 1987.

22. CHATTERJEE, A. Interaction of ionizing radiation with matter. In: FARHATAZIZ; RODGERS, M. A. J. (eds.). Radiation Chemistry: principles and applications. New York: VCH Publishers, 1987.

23. COULTATE, T. P. Alimentos e a química de seus componentes. Porto Alegre: Artmed, 2004. p. 100.

24. D'ERRICO, G.; LELLIS, M. de; MANGIAPIA, G.; TEDESCHI, A.; ORTONA, O.; FUSCO, S.; BORZACCHIELLO, A.; AMBROSIO, L. Structural an mechanical properties of UV-photo-cross-linked poly( $N$-vinyl-2-pyrrolidone) hydrogels. Biomacromolecules, v. 9, 2008. p. 231-240. 
25. DE CARVALHO, P. R. C. Medicina ortomolecular: um guia completo sobre os nutrientes e suas propriedades terapêuticas. 4. ed. Rio de Janeiro: Nova Era, 2006. p. 183 - 266.

26. DOS SANTOS, G. M., MAIA, G. A., DE SOUSA, P. H. M., DA COSTA, J. M. C., DE FIGUEIREDO, R. W., DO PRADO, G. M. Correlação entre atividade antioxidante e compostos bioativos de polpas comerciais de açaí (Euterpe oleracea Mart). ALAN. v. 58, n. 2, 2008.

27. DRAELOS, Z.D. Cosmecêuticos, $2^{a}$ triagem. Rio de Janeiro: Editora Elsevier, 2005. p. 31,32,33, 41.

28. DRAIZE, J.H., WOODARD, G., CALVERY, H.O. Methods for the study of irritation and toxicity of substances applied topically to the skin and mucous membranes. J. Pharmacol. Exp. Ther., v. 83, 1944. p. 377-390.

29. DUARTE, L. C.; JUCHEM, P. L.; PULZ, G. M.; BRUM, T. M. M.; CHODUR, N.; LICCARDO, A.; FISCHER, A. C.; ACAUAN, R. B. Aplicações de microscopia eletrônica de varredura (MEV) e sistema de energia dispersiva (EDS) no estudo de gemas: exemplos brasileiros. Pesquisa em Geociências. v.30, n. 2, 2003. P. 3-15.

30. ESCOBAR, J.L.; GARCIA, D.M.; ZALDIVAR, D.; KATIME, I. Hidrogeles. Principales Características em el diseño de sistemas de liberación controlada de fármacos. Rev. Ibero Americana Polímeros, v. 3, n. 3, 2002. p. 1-25.

31. FEl, B.; WACH, R. A.; MITOMO, H.; YOSHI, F.; KUME, T. Hydrogel of biodegradable cellulose derivates. I. Radiation-induced crosslinking of CMC. Journal of Applied Polymer Science. v. 78, 2000. p. 278-283.

32. FELDSTEIN, M. M.; TOHMAKHCHI, V. N.; MALKHAZOV, A. E.; VASILIEV, A. E.; PLATÉ, N. A. Hydrophilic polymeric matrices for enhanced transdermal drug delivery. International Journal of Pharmaceutics. v.131, 1996. p. 229242.

33. FINTER, N. B. Dye uptake methods for assessing viral cytopathogenicity and their application to interferon assays. J. Gen. Virol. v. 5, 1969. P. 419-427.

34. FRANCO, D.; GONÇALVES, L. F. Feridas cutâneas: a escolha do curativo adequado. Rev. Col. Bras. Cir. v. 35, n. 3, 2008. p. $203-206$.

35. GALERIE: Guadeloupe (Basse-Terre). Disponível em: http://www.plantesbotanique.org/src/galeries/gua08/euterpe oleracea 02.jpg. Acesso em 25/01/2009.

36. HAMIDI, M.; AZADI, A.; RAFIEI, P. Hydrogel nanoparticles in drug delivery. Advanced Drug Delivery Reviews. v. 60, 2008. p. 1638-1649. 
37. HANSON, S.; LALOR, P. A.; NIEMI, S. M.; NORTHUP, S. J.; RATNER, B. D.; SPECTOR, M.; VALE, B. H.; WILLSON, J. E. Testing biomaterials. In: RATNER, B.D.; HOFFMAN, A.S.; SCHOEN, F. J.; LEMONS, J.E. Biomaterials Science: an introduction to materials in medicine. San Diego: Academic Press, 1996. Cap. 5, p. 215-242.

38. HARRIS, M. I. N. C. Pele: estrutura, propriedades e envelhecimento. 2 ed. São Paulo: Senac, 2005. 165 p.

39. HARRIS, M. I. N. C. Pele: estrutura, propriedades e envelhecimento. 3 ed. São Paulo: Senac, 2009. p. 273-291.

40. HELLER, J. Drug delivery systems. In: RATNER, B.D.; HOFFMAN, A.S.; SCHOEN, F. J.; LEMONS, J.E. Biomaterials Science: an introduction to materials in medicine. San Diego: Academic Press, 1996. Cap. 7.8, p. 346356.

41. HERNANDEZ, M.; FRESNEL, M. M. M. Manual de Cosmetologia. 3.ed. Rio de Janeiro: Revinter, 1999.

42. HIRATA, L. L.; SATO, M. E. O.; SANTOS, C. A. M. Radicais livres e o envelhecimento cutâneo. Acta Farm. Bonaerense. v. 23, n. 3, 2004. p. 418424.

43. INSTITUTO NACIONAL DE CONTROLE DE QUALIDADE EM SAÚDE. INCQS 65.3330.003: Ensaio de irritação cutânea primária, 2007.

44. INTERNATIONAL STANDARD. Biological valuation of Medical Devices Part 1: Guidance on selection of tests, 1992 (ISO 10993-1).

45. INTERNATIONAL STANDARD. Biological valuation of Medical Devices Part 5: Tests for Cytotoxicity: in vitro methods, 1992 (ISO 10993-5).

46. INTERNATIONAL STANDARD. Biological valuation of Medical Devices Part 10: Tests for irritation and sensitization, 1996 (ISO 10993-10).

47. KIBBE, A. H. (ed). Handbook of pharmaceutical excipients. 3. ed. Washington: Pharmaceutical Press, 2000. p. 433-439.

48. LANGER, R. S.; PEPPAS, N. A. Present and future applications of biomaterials in controlled drug delivery systems. v. 2. Biomaterials. 1981. p. 201-214.

49. LIECHTY, W. B.; KRYSCIO, D. R.; SLAUGHTER, B. V.; PEPPAS, N. A. Polymers for drug delivery systems. Annu. Rev. Chem. Biomol. Eng. v. 1, 2010. p. 149-173.

50. LOPÉRgolo, L. C.; LUgÃO, A. B.; CATALANI, L. H. Direct UV photocrosslinking of poly(N-vinyl-2-pyrrolidone) (PVP) to produce hydrogels. Polymer. v. 44, 2003. p. 6217-6222. 
51. LOPES, C.M.; LOBO, J.M.S.; COSTA, P. Formas Farmacêuticas de liberação modificada: polímeros hidrifílicos. Rev. Bras. Cienc. Farm., v. 41, n. 2, 2005. p. 143-154.

52. LUBRANO, C.; ROBIN, J. R.; KHAIAT, A. Composition em acides grãs, stérols et tocophérols d'huiles de pulpe de fruits de six espèces de palmiers de Guyane. Oléagineux, v. 49, n.2, 1994. p. 59-65.

53. MACEDO, O. R. Segredos da boa pele: preservação e correção. São Paulo : Senac, 2001. 2 ed. p. 31-35.

54. MAFRA, D., COZZOLINO, S. M. F. Importância do zinco na nutrição humana. Rev. Nutr. Campinas. v. 17, n. 1, 2004.

55. MAIHARA, V. A., SILVA, M. G., BALDINI, V. L. S., MIGUEL, A. M. R., FÁVARO, D.. I. T. Avaliação nutricional de dietas de trabalhadores em Relação a proteínas, lipídeos, carboidratos, fibras alimentares e vitaminas. Ciênc. Tecnol. Aliment. Campinas, v. 26, n. 3, 2006. p. 672-677.

56. MANDELBAUM, S. H.; DI SANTIS, E. P.; MANDELBAUM, M. H. S. Cicatrização: conceitos atuais e recursos auxiliares - Parte II. An. Bras. Dermatol. v. 78, n. 5, 2003. p. $525-542$.

57. MARKS, R. The stratum Corneum Barrier: The Final Frontier. J. Nutr. n. 134, 2004. p. 2017S - 2021S.

58. MARTINS, E. F.; TORRES, R. P.; MALUF, L. M. P.; MANCINI FILHO, J.; NISHIYAMA, A; PERES, C. M.; MIYASAKA, C. K. Análise qualitativa e quantitativa de ácidos graxos por cromatografia. In: CURI, R.; POMPÉIA, C.; MIYASAKA, C. K.; PROCOPIO, J. Entendendo a gordura: os ácidos graxos. Barueri: Manole, 2002. Capítulo 4, p. $35-41$.

59. MICHNIAK-KOHN, B.B.; WERTZ, P.W; AL-KHALILI, M.; MEIDAN, V.M. Skin: Physiology and Penetration Pathways. In: ROSEN, M. R. Delivery System Handbook for Personal Care and Cosmetics Products: Technology, Applications and Formulations. New York: William Andrew, 2005. p. 78-85.

60. MIRANDA, L. F.; LUGÃO, A. B.; MACHADO, L. D. B.; RAMANATHAN, L. V. Crosslinking and degradation of PVP hydrogels as a function of dose and PVP concentration. Radiation Physics and Chemistry. v. 55, 1999. p. 709712.

61. NASCIMENTO, R. J. S.; COURI, S; ANTONIASSI, R.; FREITAS, S. P. Composição em ácidos graxos do óleo de açaí extraído com enzimas e com hexano. Rev. Bras. Frutic. v. 30, n. 2, 2008. p. $498-502$.

62. OETTERER, M.; REgItANO - DARCE, M. A. B.; SPOTO, M. H. F. Fundamentos de Ciência e Tecnologia de Alimentos. São Paulo: Manole, 2006. p. $197-242$. 
63. OLIVEIRA, M.F.; FONSECA, Y.M.; FONSECA, M.J.V. Desenvolvimento de formulações tópicas antioxidantes. Rev. Cosmetics \& Toiletries. v. 20. p. 64-68, 2008.

64. OLIVEIRA, R. B.; LIMA, E. M. Polímeros na obtenção de sistemas de liberação de fármacos. Revista Eletrônica de Farmácia. v. 3, n. 1, 2006. p. 29-35.

65. PACCHIONI, V. M. Ácidos Graxos Essenciais Ômega-3 e Ômega-6. Rev Oxidologia. n. 4, 1998. p. $30-31$.

66. PEPPAS, N.A. Hydrogels. In: RATNER, B.D.; HOFFMAN, A.S.; SCHOEN, F. J.; LEMONS, J.E. Biomaterials Science: an introduction to materials in medicine. San Diego: Academic Press, 1996. Cap. 2.4, p. 60-64.

67. PEPPAS, N.A.; BURES, P.; LEOBANDUNG, W.; ICHIKAWA, H. Hydrogels in pharmaceutical formulations. Eur. J. Pharm. Biopharm., v. 50, 2000, p.2746.

68. PEYREFITTE, G.; MARTINI, M.; CHIVOT, M. Cosmetologia - Biologia Geral - Biologia da Pele. São Paulo: Andrei, 1998.

69. PROCOPIO, J. Entendendo a gordura: os ácidos graxos. Barueri: Manole, 2002. Capítulo 4, p. $35-41$.

70. RAPADO, M., CONCEPCIÓN, D., ZALDIVAR, D., MANZURT, A., ALTANÉS, S., ROSIAK, J. M. Análisis Sol/Gel de hidrogeles de Copolímeros de Poli (Metacrilato de 2- Hidroxietilo - CO- Acrilamida) obtenidos mediante Radiaciones Gamma. Rev. LatinAm. Met. Mat. v. 23, n. 1, 2003.

71. RATNER, B.D. Biomaterials Science: an interdisciplinary endeavor. In: RATNER, B. D.; HOFFMAN, A. S.; SCHOEN, F. J.; LEMONS, J. E. Biomaterials Science: an introduction to materials in medicine. San Diego: Academic Press, 1996. p.1-8

72. RIGO, J. C., O que devemos saber sobre a suplementação de vitaminas. In: RIGO, J. C., TRAPP, M. G. (org.). O modelo e suas dicas de saúde: NATIEX - Núcleo de Atendimento à Terceira Idade do Exército. Porto Alegre: EDIPUCRS, 2008. Cap. 15.

73. ROGERO, S.O; LORENZETTI, G. C.; CHIN, G.; LUGÃO, A.B. Hidrogel de poli(1-vinil-2-pirrolidona) (PVP) como matriz polimérica para sistema de liberação de fármaco. Rev. Bras. Pesq. Des. v. 4, n. 3, 2002. p. 1447-1449.

74. ROGERO, S.O.; LUGÃO, A.B.; IKEDA, T.I.; CRUZ, A.S. Teste in vitro de Citotoxicidade: estudo comparativo entre duas metodologias. Mat. Research, v. 6, n. 3, 2003. p. 317-320 (a). 
75. ROGERO, S.O.; MALMONGE, S.M.; LUGÃO, A.B.; IKEDA, T.I.; MIYAMARU, L.; CRUZ, A.S. Biocompatibility study of polymeric biomaterials. Artif. Organs, v. 27, n. 5, 2003. p. 424-427 (b).

76. ROGEZ, H. Açaí: Preparo Composição e Melhoramento da Conservação. Belém: EDUFPA, 2000. Cap. IV.

77. ROSEN, M. R. Delivery System Handbook for Personal Care and Cosmetics Products: Technology, Applications and Formulations. New York: William Andrew, 2005. p. 7-9.

78. ROSIAK, J.; RUCINSKA-RYBUS A.; PEKALA W. Method of Manufacturing of Hydrogel Dressings. Patent U.S.A. n. 4, 871,490, 1989.

79. ROSIAK, J. M. Radiation formation of hydrogels for drug delivery. Journal of Controlled Release. v. 31, 1994. p. 9-19.

80. ROSIAK, J. M.; ULANSKI, P.; PAJEWSKI, L. A.; YOSHH, F.; MAKUUCHI, K. Radiation formation of hydrogels for biomedical purposes. Some remarks and comments. Radiation Physics and Chemistry, v. 46, n. 2, 1995. p. 161-168.

81. ROSIAK, J. M.; ULANSKI, P. Synthesis of hydrogels by irradiation of polymers in aqueous solution. Radiation Physics and Chemistry, v. 55, 1999. p. 139-151.

82. SATISH, C. S.; SATISH, K. P.; SHIVAKUMAR, H. G. Hydrogels as controlled drug delivery systems: synthesis, crosslinking, water and drug transport mechanism. Indian Journal of Pharmaceutical Sciences. v. 68, n. 2, 2006. p. 133-140.

83. SCHNABEL, W. Polymer degradation: principles and pratical applications. Munchen: Hanser, 1981.

84. SEN, M.; GUVEN, O. Radiation synthesis of poly(N-vinyl 2pyrrolidone/itaconic acid) hydrogels and their controlled release behaviours. Radiation Physics and Chemistry, v. 55, 1999. p. 113-120.

85. SOBRAL, P. J. A., MENEGALLI, F.C., HUBINGER, M.D., ROQUES, M.A. Mechanical, water vapor barrier and thermal properties of gelatin based edible films. Food Hydrocolloyds, v. 15, n. 4-6, 2001. p.423-432.

86. SPINKS, J. W. T.; WOODS, R. J. An introduction to radiation chemistry. 3. Ed. New York: John Wiley \& Sons, 1990.

87. SZÉLIGA, M. E.; BREGNI, C. Hidrogeles obtenidos por radiación gamma como sistema de liberación sostenida de flutamida. Rev. Iberoamer. Polim. v.2, n. 1, 2001. p. 1-11. 
88. TAUBE, M. B. P.; TAIEB, A. Metabolismo lipídico na cultura de queratinócitos. An. Bras. Dermatol. V. 75, n. 1, 2000. p. 75-84.

89. TOLEDO, T. C. F.; BRAZACA, S. G. C.; ARTHUR, V.; PIEDADE, S. M. S. Composição, digestibilidade protéica e desaminação em cultivares brasileiras de soja submetidas à radiação gama. Ciênc. Tecnol. Aliment. v. 27 , n. 4,2007 . p. $812-815$.

90. TURATTI, J. M.; GOMES, R. A. R.; ATHIÉ, I. Lipídeos: Aspectos Funcionais e Novas Tendências. Campinas: ITAL, 2002. 69 p.

91. WACH, R. A.; MITOMO, H.; YOSHII, F.; KUME, T. Hydrogel of biodegradable cellulose derivates. II. Effect of some factors on radiationinduced crosslinking of CMC. Journal of Applied Polymer Science. v. 81, n. 12 , 2001. p. 3030-3037. 